\title{
THE ROLE OF SOCIAL SCIENCES IN UKRAINE AND THE WORLD: MILESTONES AND OUTLOOK
}

Collective monograph

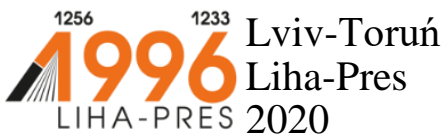




\section{Reviewers:}

Prof. nadzw., dr hab. Stanistaw Kunikowski, Rektor of Cuiavian University in Wloclawek (Republic of Poland);

Prof. $d r$ hab. Joanna Marszalek-Kawa, Uniwersytet Mikotaja Kopernika w Toruniu / Nicolaus Copernicus University (Republic of Poland).

The role of social sciences in Ukraine and the world: milestones and outlook : collective monograph / O. Boryslavska, D. Kislov, V. Liakh, N. Nesprava, etc. - Lviv-Toruń : Liha-Pres, 2020. - 216 p.

ISBN 978-966-397-190-2

Liha-Pres is an international publishing house which belongs to the category "C" according to the classification of Research School for Socio-Economic and Natural Sciences of the Environment (SENSE) [isn: 3943, 1705, 1704, 1703, 1702, 1701; prefixMetCode: 978966397]. Official website www.sense.nl. 


\section{CONTENTS}

CONSTITUALITY OF CONSTITUTIONAL REFORM:

SOME ISSUES OF CONFORMITY TO THE IDEAS

OF CONSTITUTIONALISM

Olena Boryslavska

1

STATE AND COMMUNICATIONS IN THE WORKS

OF THE THINKERS OF THE PAST

Denis Kislov

PREREQUISITES FOR HUMANISM OF THE

20TH CENTURY: EXISTENTIALISM VERSUS

DEPTH PSYCHOLOGY

Vitalii Liakh

THE CHRISTIAN PEACEBUILDING PHILOSOPHY

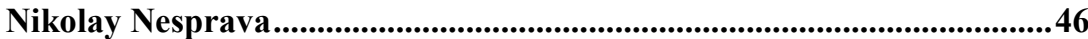

MODERN ASPECTS OF EU REGIONAL

DEVELOPMENT POLICY

Mykola Palinchak 74

SPIRITUAL DIMENSIONS

OF THE EDUCATIONAL PROCESS

Nadiia Skotna .91

TURKISH PLOT OF THE BEGINNING OF RUSSIA'S TIME OF TROUBLES: THE "HOLY WAR" PROJECT:

FALSE DMITRY I (LZHEDMITRY)

Vasyl Ulianovskyi.....................................................................................................106 
FLORENSKY AND HEIDEGGER:

CONCENTRATION OF THINKING STRATEGIES

Stepan Vozniak.................................................................................................. 130

INSTITUTIONAL INTERACTION AND POLITICAL

CHOICE IN A TRANSITIONAL SOCIETY.

WHAT ROLE FOR THE SOCIAL SCIENCES?

Liliya Yakovleva, Denys Yakovlev 146

RESEARCH PROBLEMS OF THE RELATION OF POWER AND SELF-GOVERNMENT IN THE PROCESS OF POLITICAL MANAGEMENT OF THE COUNTRY

Larysa Dunaieva 164

PECULIARITIES AND DIRECTIONS OF THE WORLD

POLITICAL AND IDEOLOGICAL DOCTRINES'

EVOLUTION IN MODERN CONDITIONS

Natalia Hedikova 178

THE PHENOMENON OF POLITICAL MULTIBRANDING IN MODERN UKRAINE

Halyna Shchedrova 194 


\section{CONSTITUALITY OF CONSTITUTIONAL REFORM: SOME ISSUES OF CONFORMITY TO THE IDEAS OF CONSTITUTIONALISM}

\section{Olena Boryslavska}

\section{INTRODUCTION}

The recent history of many Eastern European countries reveals the events that qualify as constitutional reforms. After leaving the socialist camp and starting to move toward constitutional systems based on the ideas of constitutionalism, these countries adopted new democratic constitutions (Poland 1997, Romania 1991, Slovakia 1992, Moldova 1994, Ukraine 1996) or reinstated the constitutions of the beginning of the twentieth century (Latvia 1993, Lithuania 1990). However, not a decade has passed since then, when many of them were subject to constitutional amendments (or new Constitutions were adopted, as in Hungary in 2011). Moreover, some of them significantly changed the constitutional reality.

On the one hand, this seems to be a logical process of the constitutional development of the state, which, having introduced new institutions and mechanisms for itself, refines them after some time, using the accumulated experience. However, on the other hand, an analysis of the content of such constitutional changes, as well as of the political conditions and procedures used to implement them, causes serious reflections about the possible decline of constitutionalism as well as serious problems with its functioning.

The question arises as to the constitutionality of such reforms. Under constitutionality in this case, we mean the principles of constitutionalism, which are crucial for the existence of a constitutional state: respect for human rights, separation of powers, independence of court, and rule of law rather than the formal compliance with the rules and procedures for amending the constitution.

For example, in Hungary, after the formation of the parliamentary coalition around the Fidesz party following the 2010 elections results, the process of renewing the constitutional regulation began almost immediately. Moreover, within a few months, the ruling coalition amended the constitution 10 times $^{1}$; some of the amendments were extremely controversial. At the same

\footnotetext{
${ }^{1}$ Venice Commission Opinion on three legal questions arising in the process of drafting the new Constitution of Hungary, Strasbourg, 28 March 2011, p. 8, URL: http://www.venice.coe.int/ webforms/documents/default.aspx?pdffile $=$ CDL-AD(2011)001-e
} 
time, it was decided to adopt a new Constitution, which had to completely replace the previous one. The drafting of the new Constitution in 2011 was handled by the Ad-hoc Parliamentary Constitutional Committee. The ruling party actively participated in it, while opposition members boycotted the committee's work in protest against the restriction of the powers of the Constitutional Court as a result of the 2010 constitutional amendment. Drafted by the Parliamentary Constitutional Committee, the act amending the constitution was submitted to the Parliament in March 2011, in April adopted and signed by the President ${ }^{2}$.

Such a speed and at the same time a closed procedure of preparation and adoption of the new Constitution made its discussion by political forces, mass media and civil society less possible, which was severely criticized both within the country and by the European institutions ${ }^{3}$. At the same time, the content of a number of provisions of the 2012 Constitution in their complex testifies to the desire of the parliamentary majority, the party around which it is formed, and its leader to get rid of serious constitutional restrictions and to concentrate power.

Another example is the Romanian Constitution adopted in 1991, which consolidated liberal-democratic values at the national level and created the preconditions for the formation of a constitutional government. However, in 2009 , an unsuccessful attempt was made to reform the system of separation of powers (earlier, in 2003, the Constitution was amended due to EU membership); this attempt was repeated in 2013. All this took place amid constant political conflicts, pressure on the Constitutional Court and attempts to concentrate power.

An interesting example of "unconstitutional constitutional reform" is the attempt to reform the judiciary in Poland. Another interesting fact is that this reform does occur without interfering with the text of the Constitution, but it attacks basic constitutional values and principles (which gives grounds to consider it unconstitutional). The crisis related to attempts to depend on the judiciary has been ongoing in Poland since 2015, when the "Right and Justice" political party simultaneously gained a majority in the Senate and the Seimas, formed a government and won the presidential election. Only the Constitutional Tribunal and the judiciary prevented the final concentration of power, and politicians urgently called for "reform". Without going into the details of the Polish crisis, it should be noted that it has been continuing till

\footnotetext{
${ }^{2}$ Venice Commission Opinion on the New Constitution of Hungary, Strasbourg, 20 June 2011. URL: http://www.venice.coe.int/webforms/documents/default.aspx?pdffile=CDL-AD(2011)016-e

${ }^{3}$ Venice Commission Opinion on three legal questions arising in the process of drafting the new Constitution of Hungary, Strasbourg, 28 March 2011. URL: http://www.venice.coe.int/ webforms/documents/default.aspx?pdffile=CDL-AD(2011)001-e
} 
nowadays; and the aforementioned events have received a clear assessment by the European bodies and institutions as an attack on constitutional democracy ${ }^{4}$.

As we can see, in all these cases the constitutional amendments were either aimed at concentration of power or contradicted the original ideas of constitutionalism. And this, even in compliance with formal requirements, testifies to the phenomena that contradict the essence of the constitutional state (a state with constitutionally restricted power, whose main task is to guarantee human rights and fundamental freedoms).

That is why it seems necessary to discuss an issue of the constitutionality of constitutional reform - its conformity not only and not so much with the "letter of the constitution" as with the spirit of constitutional principles, the universal ideas of constitutionalism. In addition, an important but not the only indicator of the constitutionality of constitutional reform is adherence to the established procedure for amending the Constitution, since it ensures the exercise of constituent power, which is one of the basic principles of constitutionalism and the basis for the functioning of the constitutional state, respectively.

This small study aims to develop the concept of constitutional reform, its key parameters, elements and features that ensure its constitutionality as well as its efficiency.

First of all, we will focus on the essence of constitutional reform in order to differentiate it from other related phenomena, because not every constitutional change is a constitutional reform. And from a practical point of view, it is very important to understand the technology of conducting a constitutional reform. It is clear that its effectiveness depends not only on the legal component, but also on socio-political preconditions and circumstances. However, without good legal support, constitutional reform is unlikely to succeed.

Besides this, it is very important to provide constitutional reform in the spirit of the ideas of constitutionalism, which ensures the development of the state as constitutional but not aimed at limiting human rights, usurpation or

${ }^{4}$ European Parliament resolution of 13 April 2016 on the situation in Poland. URL: http://www.europarl.europa.eu/oeil/popups/ficheprocedure.do?lang=en\&reference=2015/3031(RS P); European Parliament resolution of 14 September 2016 on the recent developments in Poland and their impact on fundamental rights as laid down in the Charter of Fundamental Rights of the European Union. URL: http://www.europarl.europa.eu/sides/getDoc.do?type=TA\&reference=P8 TA-2016-0344\&language=EN; European Parliament resolution of 15 November 2017 on the situation of the rule of law and democracy in Poland. URL: http://www.europarl.europa.eu/ sides/getDoc.do?type=TA\&language $=E N \&$ reference $=$ P8-TA-2017-0442; European Parliament resolution of 28 January 2020 on the Functioning of democratic institutions in Poland. URL: http://assembly.coe.int/nw/xml/XRef/Xref-DocDetails-EN.asp?FileID=28504\&lang=EN 
excessive concentration of power, violation of the judiciary independence or other important constitutional principles. Therefore, we will further analyze the elements and features of constitutional reform which testify to its constitutionality and effectiveness.

\section{Essense of the concept of "constitutional reform"}

Quite often, any change in the text of the constitution is understood as constitutional reform in the science. For example, Agafonova N.V. considers that the terms "constitutional amendment" and "revision of the constitution" (full or partial) are covered by the term of constitutional reform, and that constitutional reform can be considered as a generic concept of amending the constitution. Under constitutional reform, the scientist understands:

“... conditioned by the needs of society political and legal phenomenon related to the changes of the Basic Law, which are conducted on the basis of fundamental, value principles of the constitutional order, within the framework of the constitutional process and aimed at improving state organization and subordinate to the goals of social development ${ }^{5}$.

Based on the above definition, any interference with the text of the constitution will be considered as constitutional reform, even if does not alter the constitutional system, nor does it significantly affect the scope of guaranteed human rights. Contrary, as regards the amendments to the Constitution of the USA, James Sundquist divides them into essential for the constitutional system and peripheral (technical).

"Only five of the twenty-seven amendments dealt with the structure of government created by the Constitution, ... and of those five, three can be considered technical or peripheral; they corrected flaws in the design of the structure or adapted it to new circumstances without altering the nature or relationships of the institutions as the framers had conceived them. ... Even those two amendments influenced the institutions only indirectly".

As a result, he concludes that the country's state architecture has proved to be "amazingly durable" in a world change, which means essentially unchanged, not constitutionally reformed, except for the two mentioned times.

In our view, not every change to the constitution can and should be considered as constitutional reform. To be categorized as constitutional reforms, such changes must have certain characteristics.

${ }^{5}$ Ahafonova N.V. Konstytutsiina reforma v Ukraini: poniattia, instytutsiinyi mekhanizm ta zabezpechennia efektyvnosti. (Constitutional Reform in Ukraine: Concept, Institutional Mechanism and Effectiveness Support). Avtoreferat dysertatsii na zdobuttia naukovoho stupenia doktora yurydychnykh nauk. Kyiv, 2017 (in Ukrainian).

${ }^{6}$ Sundquist James. L. Constitutional reform and effective government. Washington D.C.: Brookings Institution, Revised edition, 1992. P. 4-5. 
First, they must relate to substantial issues of the constitutional order, human rights, constitutional system, separation of powers or organization of the state. Moreover, the question whether to interpret such issues as significant or not occurs in each case. Undoubtedly, examples of constitutional reform in Ukraine are the adoption of the Laws on Amendments to the Constitution of Ukraine on Justice ${ }^{7}$ or on the State's strategic course for the acquisition of full membership of Ukraine in the European Union and in the North Atlantic Treaty Organization ${ }^{8}$. Contrary, for example, the simultaneous extension of the term of office of the Verkhovna Rada and the elected local self-government bodies from 4 to 5 years within the framework of the existing system of organizing public authority did not significantly affect it, nor the status, powers or role of local self-government bodies, and therefore it was not a constitutional reform (though a solution to the issue was also outlined in the Constitution Amendment Act ${ }^{9}$ ).

It should be noted that the same textual changes can in one case significantly affect the constitutional system and in the other case be just technical. The last of abovementioned laws provided for the unification of the terms of office of the President, the Verkhovna Rada and the elected local self-government bodies without affecting the system of separation of state power or division of competencies between the state and local selfgovernment, while maintaining the balance existing at that time. However, in other political circumstances, the same change in the term of office of public authorities could have a significant impact on the political system, which should be carefully analyzed in each case of interference with the text of the constitution.

Second, adherence to the constitutional procedure for their approval is essential for qualifying amendments to the Constitution as "constitutional" constitutional reform. This is linked with the broader issue of the legitimacy of constitutional changes. Thus, of the six constitutional reforms that took place in Ukraine after the adoption of the 1996 Constitution, three were related to doubts about their legitimacy because of violations of the constitutional procedure.

${ }^{7}$ Pro vnesennia zmin do Konstytutsii Ukrainy (shchodo pravosuddia). Zakon Ukrainy vid 02.06.2016 № 1401-VIII. URL: https://zakon.rada.gov.ua/laws/show/1401-19 (in Ukrainian).

${ }^{8}$ Pro vnesennia zmin do Konstytutsii Ukrainy (shchodo stratehichnoho kursu derzhavy na nabuttia povnopravnoho chlenstva Ukrainy $v$ Yevropeiskomu Soiuzi ta $v$ Orhanizatsii Pivnichnoatlantychnoho dohovoru). Zakon Ukrainy vid 07.02.2019 № 2680-VIII. URL: https://zakon.rada.gov.ua/laws/show/2680-19 (in Ukrainian).

${ }^{9}$ Pro vnesennia zmin do Konstytutsii Ukrainy shchodo provedennia cherhovykh vyboriv narodnykh deputativ Ukrainy, Prezydenta Ukrainy, deputativ Verkhovnoi Rady Avtonomnoi Respubliky Krym, mistsevykh rad ta silskykh, selyshchnykh, miskykh holiv. Zakon Ukrainy vid 01.02.2011 № 2952-VI. URL: https://zakon.rada.gov.ua/laws/show/2952-17 (in Ukrainian). 
The first amendments to the Constitution of Ukraine were made in December 8, 2004 as a result of events that became known as the "Orange Revolution", when the society did not recognize the officially announced results of the presidential elections. Therefore, the two laws on Amendments to the Constitution and holding the third round of the presidential elections between two candidates who had received the greatest support from voters in the first round were simultaneously adopted by the so-called "package" voting. It should be noted that the adoption of the Law on Amendments to the Constitution was a gross violation of the procedures analyzed in detail in the opinion of the Venice Commission ${ }^{10}$. This became a formal ground for cancellation of the constitutional reform in 2010.

However, the submission to the Constitutional Court had been brought in before, but in 2008 the Court refused to hear the case, referring to the fact that the Law on Amendments to the Constitution after its entering into force becomes the integral part of the Constitution, and the Court does not have the authorities for the revision of the Constitution. After the presidential elections in 2010, the Constitutional Court changed its legal position and considered the Law on Amendments to the Constitution in 2004. He found it unconstitutional due to the violations of the aforementioned procedures and reinstated the Constitution of 1996. The body of constitutional jurisdiction actually had become the subject of constitutional reform, which was criticized by the Venice Commission.

Due to the events of late 2013 - early 2014, the Verkhovna Rada of Ukraine again recognized the Constitution as amended of 2004 in force, referring to the fact that the Constitution is an act of constituent power, the competence of its amending is vested only in the parliament (Section XIII of the Constitution), and the Constitutional Court which carried its decision in 2010 went beyond its powers. This was done not by the adoption of a constitutional law, as required by the section XIII of the Constitution, but by an ordinary law by simple majority of deputies. That is the reason why the legitimacy of the constitutional amendments is questionable until now.

In addition to the adherence to the constitutional procedure under the conditions of a constitutional state such features of constitutional reform that ensure the implementation of the ideas of constitutionalism guarantee the further development of the state as a constitutional one and not aimed at restricting human rights, usurpation or excessive concentration of power, violation of independence, are equally important to court or other important

${ }^{10}$ Venice Commission Opinion on the amendments to the Constitution of Ukraine adopted on 8.12.2004, adopted by the Commission at its 63rd plenary session, Venice, 10-11 June 2005. URL: https://www.venice.coe.int/webforms/documents/?pdf=CDL-AD(2005)015-e. 
issues for the functioning of the constitutional system of limited governance. In our view, such features include the legitimate aim and legitimacy of the reform itself.

Thus, mandatory features of constitutional reform (under the constitutional state) are: 1) the legitimate aim of constitutional reform, focused on achieving a legitimate result (improvement of the system of separation of powers, guarantees of human rights, organization of the state, etc.); 2) tangible, serious consequences for the constitutional system; 3) legitimacy of the reform adherence to the constitutional procedure for its implementation; 4) systemic character of the reform. An optional feature is the effectiveness of constitutional reform, which is assessed in each case by the ratio of the defined goal and the result achieved.

The above features of constitutional reform are logically related to its elements. As noted above, it is important for practice to find out a structure for constitutional reform that optimally meets the requirements of its effectiveness and constitutionality. In our opinion, based on the set parameters, the elements of constitutional reform are: 1) the purpose of reform (which must be legitimate); 2) reform strategy (should ensure the most optimal and organized way to achieve the purpose of reform; 3 ) the content of the reform (proposed changes); 4) the reform procedure (should ensure its legitimacy); 5) the mechanism of reform (covering the whole set of measures, both those envisaging amendments to the constitutional text and others necessary for implementation of the reform).

The logical link between the elements of constitutional reform and its features can be summarized in the form of a table:

\begin{tabular}{|c|c|c|}
\hline 1. & $\begin{array}{c}\text { Elements } \\
\text { of constitutional reform }\end{array}$ & $\begin{array}{c}\text { Features } \\
\text { of constitutional reform }\end{array}$ \\
\hline 2. & Purpose of reform & Legitimate purpose \\
\hline 3. & Content of the reform & $\begin{array}{l}\text { Significant consequences for the } \\
\text { constitutional system }\end{array}$ \\
\hline 4. & Reform strategy & Systemic character of the reform \\
\hline 5. & Reform procedure & Legitimacy \\
\hline 6. & Mechanism of reform & Efficiency \\
\hline
\end{tabular}

\section{Elements of the constitutional reform \\ 2.1. The purpose of the constitutional reform}

The first and basic element of constitutional reform is its purpose. It is quite clear that the goal defines all other elements of constitutional reform, preferably with the exception of the procedure, which is usually standard. However, there may be some peculiarities as well. For example, if the purpose 
of constitutional reform in Ukraine is related to the amendment of constitutional provisions on the principles of constitutional order, elections and referendums or the procedure for constitutional amendments (these issues are regulated by sections I, III and XIII of the Constitution), then the procedure will differ from the procedure for changing other sections of the Constitution of Ukraine (it is much more complex and, among other things, requires the approval of constitutional changes in a national referendum).

A wording of the objective is crucial to the success of the reform. First of all, we remind that we proceed from the provision of two key parameters of constitutional reform - its constitutionality and effectiveness. Based on these, the goal of constitutional reform should be defined as clearly and transparently as possible. First, it reaffirms the legitimacy of the goal and contributes to the legitimacy of the reform as a whole, as well as provides a basis for understanding its content; secondly, it facilitates the competent design of the reform strategy; thirdly, it allows selecting as adequately as possible the tools and the mechanism of the implementation of the constitutional reform.

An example of a poorly formulated goal, which subsequently led to negative consequences, is experience of the constitutional reforms initiated in Ukraine in 2019. While it is still too early to make a final decision whether these reforms are successful or unsuccessful, since most of them are still undergoing, it is already possible to predict the ineffectiveness, illegitimacy (in terms of support and public acceptance) of some of them.

Obviously, on August 29, 2019, on the second day of the Verkhovna Rada of Ukraine of the IX convocation, the President of Ukraine submitted seven bills on amendments to the Constitution, which were previously approved by the Verkhovna Rada of Ukraine. However, the purpose of the proposed amendments was not announced to the public by the subject of initiating constitutional reforms. In the explanatory notes to the bills, in which their purpose is to be reflected, it is either reflected in a little-verbatim (one sentence), without justification of its necessity, or is clearly stated in error.

For example, in the explanatory note to the Bill on the Abolition of the Attorney-at-Law Monopoly, it is stated that it aims to "ensure that everyone is entitled to professional legal assistance through the abolition of the lawyer's monopoly to provide such assistance" ${ }^{11}$. There is no specific justification for the need to pass such a law (despite the fact that in 2016 the Parliament introduced the Constitution completely opposite in content to the

${ }^{11}$ Poiasniuvalna zapyska do proektu Zakonu Ukrainy "Pro vnesennia zmin do Konstytutsii Ukrainy (shchodo skasuvannia advokatskoi monopolii)". URL: http://w1.c1.rada.gov.ua/pls/ zweb2/webproc4_1?pf3511=66242 (in Ukrainian). 
amendment). Therefore, the question of the expediency of such a step remained obscure to the public, which led to a mixed perception of the constitutional amendment.

Even more complicated is the situation with the draft law on advisory and other subsidiary bodies of the Verkhovna Rada of Ukraine, which was previously approved by the Verkhovna Rada on January 14, 2020. The explanatory note states that "the purpose of the proposed amendment is to legislate in the Constitution of Ukraine an effective mechanism for the organization and activity of the Verkhovna Rada of Ukraine" ${ }^{\text {"12 }}$. However, the current wording of the Constitution, without being amended, allows the creation of such bodies, some of which have already been established and function successfully.

Finding out the purpose of submitting this bill has also become a challenge for the Constitutional Court of Ukraine, which exercises preliminary constitutional control over amendments to the Constitution. In the dissenting opinion of Judge Pervomaisky O.O. it was stated that "the participants in the constitutional proceedings actually expressed their own assumptions about the purpose of the Bill" and that "the judges of the Constitutional Court were in fact limited in their ability to clarify such important circumstances of the case as the reasons and motives for presenting the bill, its true purpose ..."13.

It is obvious that the lack of a clear formulation of the purpose of the constitutional reform casts doubt on its legitimacy, necessity, expediency, which adversely affects not only its implementation but also the authority of the Constitution as a whole.

\subsection{Content of the constitutional reform}

On the basis of a clear formulation of the purpose of constitutional reform, one can proceed to formulate its content. In fact, the content of constitutional reform is the constitutional changes which aim to achieve the goal of reform. It is natural that the content of the reform should provide the most optimal and least resource-intensive way of achieving the goal and, ultimately, ensure the effectiveness of the reform.

${ }^{12}$ Poiasniuvalna zapyska do proektu Zakonu Ukrainy "Pro vnesennia zminy do statti 85 Konstytutsii Ukrainy (shchodo konsultatyvnykh, doradchykh ta inshykh dopomizhnykh orhaniv Verkhovnoi Rady Ukrainy)". URL: https://w1.c1.rada.gov.ua/pls/zweb2/webproc4_1?pf3511= 66263 (in Ukrainian).

13 Okrema dumka suddi Konstytutsiinoho Sudu Ukrainy Pervomaiskoho O.O. stosovno Vysnovku Konstytutsiinoho Sudu Ukrainy u spravi za konstytutsiinym zvernenniam Verkhovnoi Rady Ukrainy pro nadannia vysnovku shchodo vidpovidnosti zakonoproektu pro vnesennia zminy do statti 85 Konstytutsii Ukrainy (shchodo konsultatyvnykh, doradchykh ta inshykh dopomizhnykh orhaniv Verkhovnoi Rady Ukrainy) (reiestr. № 1028) vymoham statei 157 i 158 Konstytutsii Ukrainy. URL: https://zakon.rada.gov.ua/laws/show/nb03d710-19\#n2 (in Ukrainian). 
The two important aspects of the content of reform - its constitutionality and systemic nature - should be stressed. The first is related to the existence of a number of formal and substantive requirements for constitutional amendments. Modern constitutions often contain a list of prohibitions on amending them. For example, the German Basic Law forbids any constitutional amendments concerning human dignity, the division of the Federation into Lands or their involvement in the legislative process (Part 3 of Art. 79) ${ }^{14}$. The Constitutions of Italy ${ }^{15}$ (Article 139) and France ${ }^{16}$ (Part 5 of Article 89) prohibit the revision of the constitutional provisions on the republican form of government. The Constitution of Ukraine forbids amendments if they envisage the abolition or restriction of the rights and freedoms of the individual and the citizen, or if they aimed at liquidation of independence or violation of the territorial integrity of Ukraine (Article 157, Part 1$)^{17}$.

These are formal bans on constitutional changes. However, the essential requirements arising from the principles of constitutional democracy are equally important. They concern the prohibition of the abolition of human rights, voidance of their guarantees, infringement of democracy, separation of powers, independence of the judiciary or other constitutional values. Of course, the mechanism for enforcing such bans is somewhat more complicated, since in countries with an insufficiently high level of constitutional culture, where traditions of constitutionalism are not deeply rooted, a formal approach to existing bans is usually applied. In our view, in those countries where the constitutional courts are vested with the function of preliminary control over constitutional amendments, their main task is to ensure compliance with the substantive prohibitions.

The systematic nature of the content of the reform is equally important. The systematic approach ${ }^{18}$ to constitutional reform primarily refers to the development of the content of the reform considered as a set of interrelated measures aimed at achieving its goal. An example of ignoring the systematic approach to constitutional reform is the aforementioned drafts on

${ }^{14}$ Basic Law for the Federal Republic of Germany, 23 May 1949 Last amended on 28 March 2019. URL: https://www.btg-bestellservice.de/pdf/80201000.pdf

${ }^{15}$ Constitution of the Italian Republic, 27 December 1947. URL: https://www.wipo.int/ edocs/lexdocs/laws/en/it/it037en.pdf

16 France's Constitution of 1958 with Amendments through 2008. URL: https://www.constituteproject.org/constitution/France_2008.pdf?lang=en

${ }^{17}$ Konstytutsiia Ukrainy, 28 chervnia 1996 roku zi zminamy stanom na veresen 2019 roku. URL: https://zakon.rada.gov.ua/laws/show/254\%D0\%BA/96-\%D0\%B2\%D1\%80/print (in Ukrainian).

18 Yolon P. Systemnyi pidkhid. Filosofskyi entsyklopedychnyi slovnyk. Kyiv, Abrykos, 2002. S. 584. URL: http://shron1.chtyvo.org.ua/Shynkaruk_Volodymyr/Filosofskyi_ entsyklopedychnyi_slovnyk.pdf (in Ukrainian). 
constitutional amendments of the President of Ukraine, which were submitted to the Ukrainian Parliament on August 29, 2019. These are seven bills, some of which provide for interconnected constitutional changes, in particular concerning the mechanism of separation of powers and other elements of the constitutional system (such as the people's legislative veto, the powers of the President of Ukraine and the Verkhovna Rada of Ukraine, reduction of the number of parliament members, extension of the list of grounds for early termination powers of deputies, etc.).

If adopted, they can have a significant impact on the constitutional system of Ukraine. At the same time, the logic and motives of the subject of submitting drafts on amendments to the Constitution of Ukraine, unfortunately, have not been publicly announced, and therefore it is unclear what the purpose is to pursue such a "fragmented" way of carrying out constitutional reform when the proposed constitutional changes are registered in one day in the form of several separate bills.

Moreover, there is no single concept of the constitutional reforms, indicating a lack of a systemic vision. What is only evident is that such a nonsystemic approach does not contribute to either the effectiveness of constitutional reform or its legitimacy.

\subsection{Strategy of the constitutional reform}

The next element of constitutional reform - its strategy is equally important. With a clearly defined objective of constitutional reform, one can begin to develop its strategy. The latter should be based on the requirements for the content of the reform (constitutionality, systematic nature) and provide for the most optimal ways of achieving its goal.

The constitutional reform strategy includes the concept of reform and a well-thought-out plan of measures necessary for both making constitutional changes according to the established procedure (discussed below) and putting it into practice.

In addition to its direct purpose - to ensure the effective implementation of the reform - the constitutional reform strategy also has a specific task - to ensure that the reform and all its stages are accepted by society. For this purpose, modern methods of deliberation are used: consultations, broad discussions, involvement in decision-making of different parts of the society. This process is based on the principles of inclusivity (involvement), accountability and transparency ${ }^{19}$.

19 Aitamurto Tanja, Landemore Hélène. Five design principles for crowdsourced policymaking: Assessing the case of crowdsourced off-road traffic law in Finland. Journal of Social Media for Organizations, 2015. Vol. 2, Issue 1. P. 1-19. 
Such involvement of citizens in the reform discussion process, on the one hand, enhances citizens' competence by giving them advisory functions, while emphasizing the complexity of democratic decision-making and, on the other hand, does not counterbalance the role of experts and professional managers ${ }^{20}$.

\subsection{Procedure and legitimacy of the constitutional reform}

An important element of constitutional reform is the legitimate order of its implementation. We mean the adoption or amendment of the Constitution in accordance with established legal procedures that comply with the principles of the constituent power. The legitimacy of the constitution implies its recognition by the society (consensus omnium) as the Fundamental Law, supreme, with respect to other legal acts. Such recognition is possible if the constitution conforms to the will of the people, which forms the basis of its constituent power, and contains a system of guarantees of freedom and human rights (substantive aspect of legitimacy).

Formulated by Emmanuel Joseph Sieyès in the 18th century, the concept of constituent power remains relevant today and retains considerable theoretical and practical potential. According to it, the highest manifestation of sovereignty is the constituent power that belongs to the people and is primary to all other powers (legislative, executive and judicial) ${ }^{21}$. It is achieved through the establishment of a constitutional order by the people by adopting a constitution, which is an example of the constitutional power of the people exercising. Therefore, the guarantee of the implementation of this will into the text of the Constitution is compliance with the procedure of adopting or amending the Constitution (procedural component of legitimacy). Any way of adopting a constituent constitution - a special representative institution, a parliament, or combining them with a referendum - has the purpose of exercising the constituent power of the people, and in substance is the mechanism of exercising such power.

In our opinion, constitutional changes are legitimate only if: 1) they are made by a proper subject (possessing constituent power or to which such power is delegated); 2) their content complies with law (not written acts, but law as a whole, primarily natural law and its principles); 3) are made in strict

20 Kolodii Antonina. Protses deliberatsii yak skladova demokratychnoho vriaduvannia. Demokratychni standarty vriaduvannia y publichnoho administruvannia. Materialy naukovopraktychnoi konferentsii. LRIDU NADU pry Prezydentovi Ukrainy, 4 kvitnia 2008 r. Lviv, 2008. S. 106-110 (in Ukrainian).

${ }^{21}$ Sieyès, What Is the Third Estate? The Old Regime and the French Revolution. University of Chicago Readings in Western Civilization, edited by Keith Michael Baker, John W. Boyer, Julius Kirsher, General Editors. Chicago and London: The University of Chicago Press, 1987. P. 154-179. 
compliance with the procedure established by the constitution. Only compliance with all three of these conditions results in the legitimacy of the amended constitution as a whole. Failure to comply with at least one of them casts doubt on its legitimacy.

\subsection{Mechanism of constitutional reform}

The effectiveness of constitutional reform is largely ensured by the mechanism of its implementation, based on the strategy of constitutional reform and includes the totality of measures envisaged by it.

As a rule, amendment to the constitution is not a sufficient measure of the implementation of the reform. This requires appropriate continuation in the laws, as well as the practical activity of public officials. Therefore, the constitutional reform mechanism is a final and important element of constitutional reform, which will ultimately define the implementation of the reform strategy and the achievement of its goal.

Together, all the described elements and features of constitutional reform are intended to ensure the development of the state as constitutional, improving its institutions on the basis of fundamental principles of constitutionalism.

\section{CONCLUSIONS}

To sum up, constitutional reform is a complex political and legal process that reflects both the level and the direction of development of society and the state. The development of a constitutional state puts forward a number of substantive and procedural requirements to constitutional reform, the observance of which ensures its constitutionality and effectiveness.

Under the constitutionality of constitutional reform, we understand its conformity not only and not so much with the "letter of the constitution" as with the spirit of constitutional principles, the universal ideas of constitutionalism.

Constitutional reform is characterized by a number of features that distinguish it from other related political and legal phenomena, including constitutional changes. Under the conditions of a constitutional state, they include: 1) the legitimate aim of the constitutional reform - focus on achieving a legitimate result (improvement of the system of separation of powers, organization of the state, guarantees of human rights, etc.); 2 ) the consequences for the constitutional system are tangible, serious, not precise; 3) legitimacy of the reform - adherence to the constitutional procedure for its conduction; 4) systemic nature (systematic reform). An optional feature is the effectiveness of constitutional reform, which is assessed in each case by the ratio of the defined goal and the achieved result. 
The basis for effective constitutional reform encompasses several mandatory structural elements: 1) the purpose of the reform; 2) its strategy; 3) the reform procedure that ensures its legitimacy; 4) tools (mechanism) for the constitutional reform. Each of the above elements has indispensable features that, under the conditions of a constitutional state, ensure "constitutionality" (ie, conformity with the ideas of constitutionalism) and the effectiveness of constitutional reforms.

\section{SUMMARY}

Constitutional reforms and constitutional amendments are a widespread phenomenon nowadays. Politicians in different countries throughout the world often call some political and / or legal events as constitutional reforms; typical in this context are examples of post-socialist Eastern European countries. But here are two questions. First, are all of these events truly constitutional reforms? To answer it, we will identify the features that characterize the phenomenon of constitutional reform. And second, are all constitutional reforms "constitutional" in their content and implementation? Under "constitutional" we mean conformity to the ideas of constitutionalism and the desire for the development of a constitutional state. The answer to this question requires highlighting the structural elements of constitutional reform and such their requirements that ensure the constitutionality of constitutional reform, as well as its effectiveness in the conditions of the constitutional state.

\section{REFERENCES}

1. European Parliament resolution of 13 April 2016 on the situation in Poland. URL: http://www.europarl.europa.eu/oeil/popups/ficheprocedure.do? lang=en\&reference $=2015 / 3031$ (RSP)

2. European Parliament resolution of 14 September 2016 on the recent developments in Poland and their impact on fundamental rights as laid down in the Charter of Fundamental Rights of the European Union. URL: http://www.europarl.europa.eu/sides/getDoc.do?type=TA\&reference=P8-TA2016-0344\&language $=\mathrm{EN}$

3. European Parliament resolution of 15 November 2017 on the situation of the rule of law and democracy in Poland. URL: http://www.europarl.europa.eu/ sides $/$ getDoc.do?type=TA\&language=EN\&reference=P8-TA-2017-0442

4. European Parliament resolution of 28 January 2020 on the Functioning of democratic institutions in Poland. URL: http://assembly.coe.int/ nw/xml/XRef/Xref-DocDetails-EN.asp?FileID=28504\&lang=EN

5. Basic Law for the Federal Republic of Germany, 23 May 1949 Last amended on 28 March 2019. URL: https://www.btg-bestellservice.de/pdf/ 80201000.pdf 
6. Constitution of the Italian Republic, 27 December 1947. URL: https://www.wipo.int/edocs/lexdocs/laws/en/it/it037en.pdf

7. Venice Commission Opinion on three legal questions arising in the process of drafting the new Constitution of Hungary, Strasbourg, 28 March 2011, p. 8, URL: http://www.venice.coe.int/webforms/documents/ default.aspx?pdffile $=$ CDL-AD $(2011) 001-\mathrm{e}$

8. Venice Commission Opinion on the New Constitution of Hungary, Strasbourg, 20 June 2011. URL: http://www.venice.coe.int/webforms/ documents/default.aspx?pdffile=CDL-AD(2011)016-e

9. Venice Commission Opinion on the amendments to the Constitution of Ukraine adopted on 8.12.2004 adopted by the Commission at its 63rd plenary session, Venice, 10-11 June 2005. URL: https://www.venice.coe.int/ webforms/documents/?pdf=CDL-AD(2005)015-e

10. Pro vnesennia zmin do Konstytutsii Ukrainy (shchodo pravosuddia). Zakon Ukrainy vid 02.06.2016 № 1401-VIII. URL: https://zakon.rada.gov.ua/ laws/show/1401-19 (in Ukrainian).

11. Pro vnesennia zmin do Konstytutsii Ukrainy (shchodo stratehichnoho kursu derzhavy na nabuttia povnopravnoho chlenstva Ukrainy $\mathrm{v}$ Yevropeiskomu Soiuzi ta v Orhanizatsii Pivnichnoatlantychnoho dohovoru). Zakon Ukrainy vid 07.02.2019 № 2680-VIII. URL: https://zakon.rada.gov.ua/ laws/show/2680-19 (in Ukrainian).

12. Pro vnesennia zmin do Konstytutsii Ukrainy shchodo provedennia cherhovykh vyboriv narodnykh deputativ Ukrainy, Prezydenta Ukrainy, deputativ Verkhovnoi Rady Avtonomnoi Respubliky Krym, mistsevykh rad ta silskykh, selyshchnykh, miskykh holiv. Zakon Ukrainy vid 01.02.2011 № 2952-VI. URL: https://zakon.rada.gov.ua/laws/show/2952-17 (in Ukrainian).

13. Poiasniuvalna zapyska do proektu Zakonu Ukrainy "Pro vnesennia zmin do Konstytutsii Ukrainy (shchodo skasuvannia advokatskoi monopolii)". URL: http://w1.c1.rada.gov.ua/pls/zweb2/webproc4_1?pf3511=66242 (in Ukrainian).

14. Poiasniuvalna zapyska do proektu Zakonu Ukrainy "Pro vnesennia zminy do statti 85 Konstytutsii Ukrainy (shchodo konsultatyvnykh, doradchykh ta inshykh dopomizhnykh orhaniv Verkhovnoi Rady Ukrainy)". URL: (in Ukrainian).

15. Okrema dumka suddi Konstytutsiinoho Sudu Ukrainy Pervomaiskoho O.O. stosovno Vysnovku Konstytutsiinoho Sudu Ukrainy u spravi za konstytutsiinym zvernenniam Verkhovnoi Rady Ukrainy pro nadannia vysnovku shchodo vidpovidnosti zakonoproektu pro vnesennia zminy do statti 85 Konstytutsii Ukrainy (shchodo konsultatyvnykh, doradchykh ta 
inshykh dopomizhnykh orhaniv Verkhovnoi Rady Ukrainy) (reiestr. № 1028) vymoham statei 157 i 158 Konstytutsii Ukrainy. URL: https://zakon.rada.gov.ua/laws/show/nb03d710-19\#n2 (in Ukrainian).

16. Konstytutsiia Ukrainy, 28 chervnia 1996 roku zi zminamy stanom na veresen 2019 roku. URL: https://zakon.rada.gov.ua/laws/show/254\% D0\%BA/96-\%D0\%B2\%D1\%80/print (in Ukrainian).

17. Ahafonova N.V. Konstytutsiina reforma v Ukraini: poniattia, instytutsiinyi mekhanizm ta zabezpechennia efektyvnosti. (Constitutional Reform in Ukraine: Concept, Institutional Mechanism and Effectiveness Support). Avtoreferat dysertatsii na zdobuttia naukovoho stupenia doktora yurydychnykh nauk. Kyiv, 2017 (in Ukrainian).

18. Aitamurto Tanja, Landemore Hélène. Five design principles for crowdsourced policymaking: Assessing the case of crowdsourced off-road traffic law in Finland. Journal of Social Media for Organizations, 2015. Vol. 2, Issue 1. P. 1-19.

19. Kolodii Antonina. Protses deliberatsii yak skladova demokratychnoho vriaduvannia. Demokratychni standarty vriaduvannia y publichnoho administruvannia. Materialy naukovo-praktychnoi konferentsii. LRIDU NADU pry Prezydentovi Ukrainy, 4 kvitnia 2008 r. Lviv, 2008. S. 106-110 (in Ukrainian).

20. Sieyès, What Is the Third Estate? The Old Regime and the French Revolution. University of Chicago Readings in Western Civilization, edited by Keith Michael Baker, John W. Boyer, Julius Kirsher, General Editors. Chicago and London: The University of Chicago Press, 1987. P. 154-179.

21. Sundquist James. L. Constitutional reform and effective government. Washington D.C.: Brookings Institution, Revised edition, 1992.

22. Yolon P. Systemnyi pidkhid. Filosofskyi entsyklopedychnyi slovnyk. Kyiv, Abrykos, 2002. S. 584. URL: http://shron1.chtyvo.org.ua/Shynkaruk_ Volodymyr/Filosofskyi_entsyklopedychnyi_slovnyk.pdf(in Ukrainian).

\section{Information about the author:} Olena Boryslavska,

Doctor of Juridical Sciences, Docent, Professor at the Constitutional Law Department, Ivan Franko National University of Lviv ORCID: https://orcid.org/0000-0001-8338-0966 Researcher ID: https://publons.com/researcher/H-2177-2019/ 
DOI https://doi.org/10.36059/978-966-397-190-2/17-31

\section{STATE AND COMMUNICATIONS IN THE WORKS OF THE THINKERS OF THE PAST}

\section{Denis Kislov}

\section{INTRODUCTION}

The contemporary scientific discourse on the definition of the essence and nature of communications and communicativeness in the political, state, and economic fields is becoming more and more critical and fundamental. This situation demands a more thorough insight into the historical concept interpretation evolution based on an understanding of the interrelationships of management and communications at various historical periods, which is reflected in the works of the most prominent thinkers of the past. At the same time, this comparative analysis should take into account a contemporary view of the essence, meaning, and nature of these phenomena within the context of their relation to political and social processes. The initial documented theoretical descriptions of these processes encompass the period of state formation in the age of antiquity and Ancient China. The ideas of philosophers of that civilization period are still relevant and demanded in contemporary theoretical developments. The key motive of this publication is to demonstrate this dependence and the relevant recourse to the works of the prominent thinkers of the past for rethinking the contemporary concepts from a standpoint of universal values. The purpose of this chapter is to analyze the evolution of the views of ancient thinkers' communications and management phenomena in terms of the contemporary understanding of these terms. The methodology used in this study employs a system approach and a comparative historical analysis. In the history of philosophical and political thought, there were certain sufficiently sound ideas of interrelationships between the authorities and the population, which may serve as a basis for developing new concepts or revaluing the existing ones. The scientific novelty of this publication consists in the detailed and systemic rethinking of the thinkers' views at the earlier stages of statehood from the perspective of the contemporary theory of civilization management and communication relationships for the $21^{\text {st }}$ century. A heated discourse within the national research and management community is presently held on the concept of the New Public Management that started in the West back in the 1980s - 1990s. Ideas proposed to improve the efficiency of management decisions rely on a proposal to upgrade the interaction of communications systems of stateowned, private, and nongovernmental institutions. And it points again to the 
relevance of focusing on the essence of the initial theoretical statements free from any experience of others and from ideologies.

An analysis of theoretical works dedicated to the development of state and political information and communications systems taking into account past historical experience shows that the focus of a number of national and foreign authors on historical analogies and appeals is growing. Within the context of this chapter theme and from the political and information perspective the following Ukrainian researchers should be emphasized: V. Bebik, O. Zernetska, V. Rizun, A. Kholod, and also researchers focusing on communications in connection with the state administration issues such as V. Bakumenko, A. Bukhtaty, N. Dragomyretska, V. Ivanov, L. Klymanska, V. Kniazev, E. Romanenko, G. Pocheptsov. Foreign specialists working in this field from the historical perspective relevant to the antiquity era include G. Gersimova, T. Kessidis, K. Kule, U. Eco, and several other authors.

\section{Understanding communications in the political processes of the state system of antiquity}

In the period when philosophical views on political processes of antique slave owning states (late $7^{\text {th }}$ century - early $6^{\text {th }}$ century B.C.) were formed at the time of the Seven Wise Men of Ancient Greece, the first statements on the role of information and communications (as translated into the contemporary language) was made by one of them - Bias of Priene.

In the ideal state concept described in the works of Plato (427-347 B.C.) such as "State", "Critias", "Polity", and "Laws", communications management was considered in the context of "kingdom of art" based on the knowledge and talent of communications among (free) people and communications between the authorities and people (with free citizens and warriors). The political communications art according to Plato is an ability to weave a political fabric for the electoral unity of brave, prudent, and friendly like-minded people. Plato believed that the public and private life of citizens, the level of information and communications available to them should be regulated only through a thorough legislative system. He proposed a balanced approach to regulation of communicative relationships in a system of democratic state administration, emphasizing that art primarily relies on the "knowledge of what is beautiful and useful, artistic knowledge of justice in the state"1.

According to Aristotle (384-322 B.C.), the state is the highest form of communications, but only for free citizens who may participate in legislative,

${ }^{1}$ Plato. (1999) Zakony [Laws] / translated from Ancient Greek by A. Losev, V. Asmus, A. Godi. Moscow. Mysl, p. 618. 
judicial, and military activities. Aristotle viewed only "polity" as an ideal form of the state in the form of an original unity of democracy and oligarchy (in antique terms). He believed that a middle class is to be artificially formed through the proportionate and electoral recruitment of poor class representatives for public posts in order to ensure the optimal administration of this form of statehood. Interrelations between free citizens (slave owners) and slaves, craftsmen and the other categories of the population, just as all the types of family relations, were thought by Aristotle to be beyond the political communications zone. He was the first to introduce the classification of what we call communications. Aristotle classified them into regulated, substatutory, formal, informal, and unregulated communications. His "to each their own" maxim referred to the delimitation of the sphere of influence and communications corresponding to it. It means that in the state everyone has to do what they have to and not to interfere with relationships of other categories of the population. In other words, all types of political communications are strictly divided and intertype ones are extremely limited. Aristotle believed that this would ensure fair reconciliation of the state's objectives and the relevant balanced "reconciliation of laws to achieve the general welfare of citizens"2.

Until the mid-20 ${ }^{\text {th }}$ century, the structure of communications was considered as proposed by Aristotle according to the speech formula divided by him into three components: "orator", "subject matter he talks about", and "person he addresses" . The content of communications was specified according to G. Lasswell's formula obtained based on long scientific research into the radio as the media and its impact on the American society in 1937-1948. Unlike Aristotle's three-dimensional formula, it consisted of five elements of the communications process ${ }^{4}$.

In the years to come and until our time, this has pushed to the permanent increase in the number of elements of communications formulas. In the second half of the $20^{\text {th }}$ century - the early $21^{\text {st }}$ century, fuller records of the content of messages were attributed to authors of new communications formulas. However, Aristotle defined the proportion between the content and scope of concepts communicated from the orator (communicator) and a person. According to Aristotle's logic, a higher scope of concepts in communication decreases their content and vice versa, but it was not reflected

2 Aristotle (2000) Polityka [Polity] / translated from Ancient Greek and foreword by O. Kysliuk, Kyiv, Osnovy, p. 88.

3 Aristotle. Retorica [Rhetoric] (2000) Poetry / translated from Ancient Greek by O. Tsybenko. Moscow, Labirint, p. 197.

${ }^{4}$ Kislov D. (2019) Establishment of scientific research in communication studies in the 1920s - 1930s. History of science and technology. Vol. 9, issue 1 (14). P. 105. 
in his formula. The freedom of communication and the freedom of information distribution were directly linked by Aristotle to the process of emergence and development of city-states, statehood, and democracy and for him this was an inseparable attribute of their existence just as man's ability to speak.

The need to influence the enemy's human communication and the military forces, other facilities arose at the early stages of statehood establishment. Such communicative measures were implemented by way of disseminating rumors, myths, information on the invincibility and power of the conquerors' troops. And information on such measures supposed to be implemented long before they were really implemented in the specific area have been known since the ancient times from the Bibles, annals, and chronicles, from antique and oriental myths, folklore of different countries and nations.

Dissemination of information on invincibility was successfully used by Aristotle's pupil: Alexander the Great. This was his strategic technique and permanent component of brilliant victories and fast conquests of vast territories. Information on Alexander the Great's victories was disseminated across the territories of potential enemies to spread fear and panic among the adversary's population and troops. This worked until his troops met an enemy with a fundamentally different code of information fears and prejudices. Moreover, Alexander the Great used a method that was later called "connection": inclusion of a new item in the old mythology.

Before the final conquest of Greek city-states (poleis), Alexander the Great imposed a condition, according to which all their citizens had to recognize him as a son of Zeus, although the ancient world back then was well aware that he was the son of King Philip II. Having uneasily admitted this allegation, residents of ancient Greek city-states made their first important step toward a loss of democracy, which later had a significant effect on the consciousness of all the surrounding countries and nations of the antique world ${ }^{5}$. Over thousands of years, the connection method was tested and is still successfully used by political strategists when the mythologeme of one system, formation needs to be replaced with another one (the positive one with the negative one and vice versa). This method became an infallible tool of an information war particularly in case of discrediting the current or past personalities not at the best time of social and economic transformations.

In the ancient world, similar substitutions happened not just to personalities, but to certain concepts as well, representing an information war technique. For example, the initial term "demagogue" meant a national chief,

${ }^{5}$ Pocheptsov G. G. (2002) Psikhologicheskie vojny [Psychological wars]. Moscow. Reflbook, Kyiv. Vakler, p. 225. 
a democratic politician within the state system as viewed in the antique world, although a people was defined as all the free slave owning citizens of a citystate and included only men. Later, in the period of an external struggle against the democratic system, this term was ironically and scornfully applied to individuals defending the previous principles. As a result, the term "demagogue" was transformed and began to mean a public figure deceiving people by unfeasible promises, false mottos, flattery, manipulation or misrepresentation of facts. In other words, demagogues and false informers (misinformers) became the leading fighters of information wars. As a method of consciously constructed false statements and calls hiding selfish and egoistic objectives, demagogy has been used for thousands of years and will be used as long as an information and political struggle exists.

In his work "History of Rome", Theodor Mommsen provided a detailed and bright description of the life in this antique state's capital. Liars and boasters could be easily found and used for disseminating any rumors in Rome. T. Mommsen wrote that there were enough chatterboxes and rascals capable of discrediting others and ready to do everything they were ordered to: tell lies, say bad things about something good and vice versa, act as false witnesses, false prophets, and disseminate any disinformation ${ }^{6}$. And such lumpen people were actively used in Ancient Rome as elements of oral communication in the information component of political and military struggle. According to Cornelius Tacitus, rumors and dirt were actively used behind the screen of "vox populi", i.e. voice of the people, against competitors, enemies and opponents of politicians and legionaries?

T. Mommsen's insight into the everyday life, behavior, and destinies of Roman residents made it possible to develop models of ancient analogies of ordered information and disinformation dissemination systems through oral communications. And such models based on the moral and psychological condition of society in the Roman State are quite an efficient tool in comparative historical analogies. T. Mommsen clearly emphasized the role of spectacular communications with elements of murders and violence (Roman holidays, including during burials, hunting and killing wild animals in the presence of large crowds of people, including children) in the formation of the society's customs and psychological condition of that time. Contemporary cinema and television strictly follow this path of Roman society, which leads to deterioration and decay, but not spontaneously as in was in the ancient

\footnotetext{
${ }^{6}$ Mommsen T. (1997) Istoriya Rima : $v 4$ tomah [History of Rome: in 4 volumes]. Rostov on Don. Fenix, v. 2: Unification of Italy before the conquest of Carthage and Greek states (book III continuation). Revolution (book IV). P. 194.

${ }^{7}$ Tacitus C. (1969) Istoriya. Istoriki Rima [History. History of Rome]. Moscow. Nauka, p. 348.
} 
world, but in a fully aware and purposeful way as an element of information wars.

T. Mommsen clearly demonstrated that the "revolution of vicious practices" in Rome was followed by economic crises, revolutions, ruin, and enslavement by barbarians - arriving conquerors. The vicious population was unable to resist aggressive and cruel conquerors. He wrote that if a person receives no satisfaction from labor, works only to enjoy life, he/she does not become a criminal thanks to a happy occasion. The destiny generously offered all the benefits associated with power and wealth to Romans, but the can of worms actually turned out to be a gift with dubious merits ${ }^{8}$. This thesis written about 165 years ago (in 1854-1856) is still relevant for the contemporary Euro-Atlantic civilization as well.

Artificially formed misinforming rumors were disseminated in Ancient Rome by specially trained people. They were an efficient tool for discrediting certain officials and changing the mood of the crowd, which stated requirements and calls wanted by their intriguing organizers.

However, this threat still affects many present-day politicians as well. The same motto (voice of the people) is currently used by some political analysts along with a group of tame media professionals to persuade that a show demagogy is a real popular opinion by relying on audiences prefabricated and adapted to their objectives. However, this is not done in the marketplaces of Ancient Rome, but on the scenes of reputed contemporary television channels.

Gaius Julius Caesar (100-44 B.C.) used the method of spectacular entertainment communications for the purposes of information support of his power and message as well. He initiated various massive spectacles, holidays, jubilees, and other similar events. This was the beginning of targeted image and marketing (as understood today) actions and measures permitting to widely disseminate the information on the greatness and importance of J. Caesar, on his perpetuation not just among his contemporaries, but in the history of humankind in general. According to Plutarch in his Comparative Life Descriptions, J. Caesar actively used bribery, rumors, and also other methods for various purposes and in various situations, obtaining finally "the greatest benefits at a low price" (Plutarch, 2008). Manifestations, ceremonies, magnificent spectacles were sufficiently bright, colorful, and large-scale events at that time. They all were prototypes of methods and technology of psychological effects on the consciousness of people. Mechanisms and tools of such effects have not, in principle, changed since that time.

\footnotetext{
${ }^{8}$ Mommsen T. (1997) Istoriya Rima : v 4 tomah [History of Rome: in 4 volumes]. Rostov on Don. Fenix, v. 2: Unification of Italy before the conquest of Carthage and Greek states (book III continuation). Revolution (book IV). P. 197.
} 
In the ancient world, prophecies spread by oracles, priests, and other sources reputed at that time were widely used in information conflicts to efficiently manage the collective consciousness. This method has never been disdained. Prophecies of the end of the world or other apocalypses circulated from time to time today become practically the main theme of all the media outlets causing mass psychoses that can divert the population from more relevant and practical themes and objectives and justify unpopular measures. Therefore, the principles of impacting the collective consciousness developed in the antique world have never changed or become outdated. These methods are still efficient in contemporary information wars, but they have new communications and technological forms.

The political and theoretical thought of Ancient Rome was most vividly described in the works of Marcus Tullius Cicero (106-43 B.C.). Relying on Polybius's opinions about the Roman society as a synthesis of the monarchy, aristocracy, and democracy, he followed Plato's theoretical instructions. Cicero established the general theoretical and legal basis for international political communications and theory of wars described in his works such as "On Laws", "On the State" known as the Dialogues on the state9. He defended an aristocratic, particularly careful and balanced attitude to communications in management. In particular, Cicero introduced the concept of just and unjust wars, which is still used in the theories of wars by all ideologies. The basics of the doctrinal definition of information wars appeared more than 2,000 years ago, but their essence and link to the state policies were rethought only in the $20^{\text {th }}$ century when definitions associated with information technology were introduced in the legislative practices of many states.

Therefore, new methods and technology of public management and their further improvement will not be developed in a sustainable and full manner without rethinking the heritage of the antique understanding of the development of human communications in the political processes of the state.

\section{Management and communications issues as priority of Ancient Chinese thinkers}

An analysis of the historical period of development of theoretical management and communication ideas and principles in the context of the formation of the key schools of philosophy in Ancient China points shows the careful attention of the representatives of Confucianism, Laoism, and Moism in the $6^{\text {th }}-3^{\text {rd }}$ centuries B.C. to the issues of communications between the

\footnotetext{
${ }^{9}$ Macklin I. and Macmillan A. (2005) Korotkij oksfords 'kij poli'tichnij slovnik [Brief Oxford political dictionary] / edited by, translated from English by V. Sydorov and others, Kyiv, Osnovy, p. 746.
} 
authorities and the population. The typical feature of the era called "Struggle of Kingdoms" was a consistent aspiration to establish a united centralized state and relevant attempts to bring together the theory and practice in the state administration reformation by recruiting the representatives of thenfamous schools of philosophy, being just established, to the administrative bodies.

Methods of influencing the population, enemy environment and armies in the period of statehood development in the Middle East, Central and SouthEast Asia are described in the legends and history of oriental nations. Rumors of the super power of any conquerors were always disseminated in advance in the territories to be aggressed.

The history of political thought knows the theoretical concepts of Chinese philosophers concerning the nature of power, state development, and the role of governors, the people, officials, and relationships between them. Certain communication interdependence of the authorities and a man of the people is a specific feature of both the myth creation and ancient Chinese ideology and philosophy ${ }^{10}$.

The clearest definitions of communications in the context of understanding the society and state management issues of that time were given by the prominent thinkers of Ancient China: founders of the first schools of philosophy in the $6^{\text {th }}-2^{\text {nd }}$ centuries B.C., who have had a significant impact on the further development of management thought even on the contemporary growing state power of this country being the second largest economy in the world. Their treaties include statements containing a communicative element, which reflects the principles of relationships between government and the population: governors, officials, and subjects. This attention to such issues was dictated by the growing output of labor, land reforms, and a struggle for developing a united centralized state. This points to the first insights into a link between information and communications, and also the use of information for political purposes and goals, i.e. to oppose other doctrines, enemy intentions, and in a number of other administrative functions.

Early politicization and certain socialization of ancient Chinese philosophic thought were caused by a fundamental transformation of the country's social and state structure, increasing interest of the government elite and all the administrative communities in upgrading, significantly improving the state administration system. In the process of being established, the first schools of philosophy tended to be encompassed by the state and their prominent representatives were engaged in the administration activities with

${ }^{10}$ Rubin V. A. (1969) Chelovek v drevnekitajskoj my'sli [Man in ancient Chinese though]. Peoples of Asia and Africa. No. 6. P. 65. 
philosophers being invited to public offices and a philosophical administrative academy being set up in the Chi Kingdom. These processes were accompanied by heated and live discussions, bitter debates between representatives of different schools. There was a wide discourse on the formation of the state administration principles and methods, relationships between the governor, officials, and the people, i.e. communications between them in contemporary terms.

Confucius or Kong Fuzi (551-479 B.C.) was the most important and influential figure among ancient Chinese thinkers, who was one of the first philosophers to propose his views and principles on these issues ${ }^{11}$. His doctrine described by his disciples in the Discussions and Judgments treaty shows clear requirements for methods of administering countries and peoples based on generalized and improved moral and ethical rules followed in large Chinese families and society. This doctrine was later called Confucianism. Confucius's historical role, importance, and authorship was recognized in the $2^{\text {nd }}$ century B.C. Obligatory examinations on the basics of classical Confucianism to be passed by Chinese officials were introduced in 125 B.C. and remained unchanged for over two thousand years. An official had to pass them successfully to be admitted to the imperial service. This tradition is still respected and improved for public office. Under the first governor of the Khan dynasty (202 B.C. - 220 A.D.), Confucianism was declared the official state ideological doctrine ${ }^{12}$. Confucianism continues having a serious ideological importance for the formation of contemporary power of the People's Republic of China. The philosophical field called Confucianism began to develop only in the $11^{\text {th }}$ century A.D. although Confucius created his special ethical and political system of views and concepts of state administration one and a half thousand years before that. This is quite normal from a historical standpoint. $\mathrm{He}$ based state administration on ethical rules and moral principles to be followed by governors and officials of all the state hierarchy levels. The moral example of a statesman's conduct is the main ethical principle underlying the trust placed by the population in government and one of the key administration principles.

The art of communication (in the modern sense) plays a well-deserved place in its "proper state administration" system. Confucius believed that the conduct of subjects can be influenced only through direct communications,

11 Ostapets Yu. (2011) Konfuczi’j. Poli'tichna encziklopedi'ya [Confucius. Political Encyclopedia] / edited by Yu. Levenets and others, Kyiv. Parliamentary Publishing House, p. 363.

${ }^{12}$ Macklin I. and Macmillan A. (2005) Korotkij oksfords 'kij poli'tichnij slovnik [Brief Oxford political dictionary] / edited by, translated from English by V. Sydorov and others, Kyiv, Osnovy, p. 341. 
helping maintain stability and honesty in society. He showed a natural example to draw an analogy of this communications model of influence: wind - grass. The power of wind (administration system - administration body) has a direct impact on grass (the population - administered subject) by sagging and directing it. As a result, he recognizes only the unilateral direction of communications in the "government - subjects" system (Confucius, 2006).

Confucius recommended maintaining a reliable distance between the populace and government at all times and preached that government should be internally closed. He believed that communicativeness should be most reasonably implemented through rituals. According to Confucius, communications consisted of three components of "a proper way" - "Tao". These three components included the "zhen" hieroglyph meaning humanity and two symbols: "man" and "two". In this way, the hieroglyph expressed relationships between people. The second component was the "reciprocity" concept - "shu". The third key component was the "golden mean" concept "chzhun-yun", achievement of which was the most complicated and difficult process to ensure an understanding of reciprocity through the stable communicative interaction between people.

Various doctrines that emerged in Ancient China before Christ also included doctrines covering communications to some extent, but in a less deep and consistent manner than Confucianism. One of them, called "moism", was founded by Mozi in the $5^{\text {th }}$ century B.C. Shan Yan was a leader of another field in the $4^{\text {th }}$ century B.C. called "legism". In the late $3^{\text {rd }}$ century B.C., criteria for approaches to an understanding of the "communications balance" between different classes of the population arose in the context of interpretations of these fields. A theoretical attempt to find this balance of interests through communications components was good and promising, although it had no chance of being recognized back then. But the motto saying that "the rich will share with the poor" was later derived from this doctrine and became unfeasible. This unrealistic postulate has existed for over two thousand years. It still suits some present-day politicians from time to time, in which case this motto appears in a new form. Besides, there are attempts not just to proclaim it again, but to implement it in social practice without being aware of this thesis origin, full context, and meaning. Millennium-long experience in failing to implement and permanently misstating this thesis is far from embarrassing importunate demagogues - its apologists as they confuse even nowadays the mind of contemporaries from time to time with outdated false theories refuted by historical practice.

These techniques tested for thousands of years are still successfully used by political strategists in social communications when the mythologeme of 
one system, formation needs to be replaced with another one (the positive one with the negative one and vice versa) and continue to have a limited communicative effect. This method became an infallible tool of an information war particularly in case of discrediting or, otherwise, exalting the current or past personalities not at the best time of social and economic transformations.

A doctrine opposing Confucianism and Moism appeared later and became one of the main teachings in Ancient China; it was stated in the same-name treaty called Zhuangzi in the form of polemic parables calling for return to natural sources of being, i.e. a simple and plain life embodied in dao. Daoism emerged in the early $4^{\text {th }}$ century B.C. and became one of the religious movements in the $2^{\text {nd }}$ century B.C. when Lao Tzu's Dao De Zin treaty was published (Yan Khin-shun, 1950).

Later in their works the prominent representatives of China's schools of philosophy departed from strictly patriarchal, family-based approaches to the society's political life, administration, and communications in its various communities and structures. Search for the optimal forms of organizing society by using the quality of the governors and the governed became the main idea in the teachings of Chinese thinkers. Only a balance and optimal relation of the skills of administrators and society in combination with properly developed communications ensure the order and stability in the state.

At present, not only scientific discussions, dedicated to social administration and the role of communications between government and the population, are held in South-East Asia, but there is a real struggle of the conceptual principles of the development of the national state administration bodies. At the same time, this struggle extended to international systems and transnational corporations, which are playing an increasingly important role in the system of inter-state relations. Stability or instability of the present and future new world order now depends on the results or consequences of this struggle of different management and communications concepts. A two-year trade war between the USA and China, the world's two most powerful economies (accounting for one third to $40 \%$ of the global GDP), is a bright example of this struggle. At the very beginning of 2020, the trade conflict finally returned to the first phase of official agreements: conclusion of the first compromise agreements, which may have a positive impact on the total global situation. However, a no less fierce conflict and, at the same time, interaction of these states in other areas of the global activities due to discrepancies of fundamental worldview concepts will continue for a long time.

An updated oriental philosophical and administration teaching called "Dao" is one of such concepts; it encompasses the fundamental principles of Confucianism, other Chinese doctrines mentioned above and contemporary 
management concepts. Dao actually constitutes a worldview basis of a synergetic approach to management of sophisticated multidimensional nonlinear systems of contemporary society, synthetized based on the experience and many management ideas proposed by South-East Asian thinkers of the past. For instance, one of the postulates of Daoism still used shows that "an object receives life by being implanted in an empty flow of rearrangements" $" 13$. In other words, the world around us is a dynamic process of interactions and changes. This is emphasized in the Book of Changes stating that the laws of nature are not external forces with respect to objects; they make movements proper for objects harmonious ${ }^{14}$. Therefore, both management and communications represent the predicted patterns of the concept of spontaneity of all in the philosophy of the public system, common sense, and practical knowledge.

In the modern sense, this is an organization concept of society administration. The Chinese society administration and the state functioning methodology are deeply based on the philosophical principle of an organic link between man and nature. This principle along with the Chinese devotion to their traditional mental perception of statehood in any forms and in conjunction with all the natural processes explains the high stability of the Chinese civilization and also clarifies the prompt and impressive success of China on the international arena.

\section{CONCLUSIONS}

The studies and analysis of the first historical ideas and theoretical concepts of the role, place, and importance of communications in the state administration systems proposed by the pleiad of the prominent thinkers of the past permit to rethink the sources of conceptual principles of communication studies determined in the $20^{\text {th }}$ century and approach the objective evaluation of the prospective role of the communication component of the humankind civilization development in the $21^{\text {st }}$ century.

Although the first brave intuitive speculations about the role of relationships between government and the population were proposed back in the $6^{\text {th }}-3^{\text {rd }}$ centuries B.C., and theoretical views on the processes and role of communications in the state administration of various periods are presented in the works of the prominent political thinkers of that time, a scientific understanding of the importance of communications for the development of

${ }^{13}$ Maliavin V.V. (2000) Sumerki Dao : Kul'tura Kitaya na poroge Novogo vremeni [Dao darkness: Chinese culture at the threshold of the New Time] Moscow. Design, p. 44.

14 Kapra F. (1994) Dao Physici [Dao of Physics] / translated from English by P. L. Grokhovsky, S. Petersburg: ORIS, p. 198. 
the earth civilization came only when mass communications technology and means became available and began to be widely used in the second quarter of the $20^{\text {th }}$ century.

By the start of the $2020^{\text {th }}$, the humankind had approached the need of an objective scientific understanding of the dominating role of all the types of communications in the general theory of noospheric management of social and economic processes on the Earth in general. What ancient philosophers made intuitive statements of and what $\mathrm{M}$. Weber tried to draw the society's attention to (at the end of World War I), then V. Vernadsky (at the end of World War II), and several other researchers not long ago, has now become an imperative and practical requirement. But this process of rethinking the need for and urgency of a new comprehensive management and communications paradigm is far from being completed and must go through a difficult and heated discourse.

Organistic management concepts of the East relied on the ideas of philosophers of Ancient China. Concepts of antique thinkers were quite similar to them, but practices of management technology fundamentally differed in the historical development process. They were incorporated in the different civilization systems of the West and the East. Only recently have eastern management theories and practices found feedback in the contemporary European management science. This process is even more difficult in the American management science, but it is becoming more and more acceptable, important, and even influential. The synergetic effect will take place only when these management movements departed in the past historical development get synthesized into a comprehensive concept of managing the new world order based on updated organistic and noosphere theories.

\section{SUMMARY}

The Chapter looks at the role and importance of communications in the systems of administration of state bodies in Ancient Greece, Rome, and China as reflected in the works of the prominent thinkers of that time according to their understanding of the essence of this phenomenon in the relevant historical period. It shows that the history of philosophical and political thought knows some well-grounded concepts of relationships between government and the population. Worldviews of antique and ancient Chinese thinkers are rethought in a detailed and systemic manner from the perspective of the contemporary theory of management and communications relationships for the $21^{\text {st }}$ century. It considers methods of practical impacts on the enemy's communications, on the population of their own and neighboring countries, the enemy's structures and other facilities arising in the statehood 
establishment period, including in parallel in the territories of South-East Europe and Asia in the $6^{\text {th }}-3^{\text {rd }}$ centuries B.C.

We analyzed the impact of Plato's and Aristotle's management and communications ideas on the subsequent works of Plutarch, Caesar, Cicero, and other antique authors as well as the influence of their ideas on the concepts of contemporary researchers. It is shown that Aristotle's communications formula has had a dominant and exclusive impact on the understanding of this phenomenon for over two thousand years. The Chapter presents the key principles of Confucius's doctrine bearing on the fundamental issues of management, hierarchy of government and their internal communications, social and ethical rules of relationships between officials and the people, communications between government services and society.

\section{REFERENCES}

1. Aristotle (2000) Polityka [Polity] / translated from Ancient Greek and foreword by O. Kysliuk, Kyiv, Osnovy. [in Ukrainian]

2. Aristotle. Retorica [Rhetoric] (2000) Poetry / translated from Ancient Greek by O. Tsybenko. Moscow, Labirint. [in Russian]

3. Kapra F. (1994) Dao Physici [Dao of Physics] / translated from English by P. L. Grokhovsky, S. Petersburg: ORIS. [in Russian]

4. Kislov D. (2019) Establishment of scientific research in communication studies in the 1920-1930s. History of science and technology. Vol. 9, issue 1 (14). P. 99-108. DOI: https://doi.org/10.32703/2415-74222019-9-1(14)-99-108 [in Ukrainian]

5. Macklin I. and Macmillan A. (2005) Korotkij oksfords'kij poli'tichnij slovnik [Brief Oxford political dictionary] / edited by, translated from English by V. Sydorov and others, Kyiv, Osnovy. [in Ukrainian]

6. Maliavin V.V. (2000) Sumerki Dao : Kul'tura Kitaya na poroge Novogo vremeni [Dao darkness: Chinese culture at the threshold of the New Time] Moscow. Design. [in Russian]

7. Mommsen T. (1997) Istoriya Rima : v 4 tomah [History of Rome: in 4 volumes]. Rostov on Don. Fenix. [in Russian]

8. Ostapets Yu. (2011) Konfuczi'j. Poli'tichna encziklopedi'ya [Confucius. Political Encyclopedia] / edited by Yu. Levenets and others, Kyiv. Parliamentary Publishing House, p. 363. [in Ukrainian]

9. Plato. (1999) Zakony [Laws] / translated from Ancient Greek by A. Losev, V. Asmus, A. Godi. Moscow. Mysl, p. 618 [in Russian]

10. Pocheptsov G.G. (2002) Psikhologicheskie vojny [Psychological wars]. Moscow. Refl-book, Kyiv. Vakler. [in Ukrainian; in Russian] 
11. Rubin V.A. (1969) Chelovek v drevnekitajskoj my'sli [Man in ancient Chinese though]. Peoples of Asia and Africa. No. 6. p. 74-85 [in USSR]

12. Tacitus C. (1969) Istoriya. Istoriki Rima [History. History of Rome]. Moscow. Nauka. [in USSR]

\section{Information about the author:}

Denis Kislov,

Institute of Law and Public Relations, Open International University of Human Development "Ukraine"

23, Lvivska str., Kyiv, 03115, Ukraine

ORCID: https://orcid.org/0000-0002-9112-9832 
DOI https://doi.org/10.36059/978-966-397-190-2/32-45

\section{PREREQUISITES FOR HUMANISM OF THE 20TH CENTURY: EXISTENTIALISM VERSUS DEPTH PSYCHOLOGY}

\section{Vitalii Liakh}

\section{INTRODUCTION}

In the postmodern era, when previous ethic largely lost its validity and prescriptive power, humanities were challenged to find new ways of development, to define new connotations and meanings for it. This became especially relevant after M. Foucault's famous statement that "man died" or another thesis of the same content about the "death of the subject". In the second half of the twentieth century there emerges even theoretical antihumanism, which testified a turn from understanding a person as a selfsufficient being, who unaidedly determines his path to authenticity, to comprehending him as a being dependent, deterministic, predetermined, independent. This process began at the end of the 19th century, when, under the influence of a certain depreciation of the individual and the general atmosphere of decadence, the philosophy gave rise to the concepts in which a person is interpreted as something imperfect, dependent, incomplete. Darwin's theory of the origin of species, critique of biblical texts from the perspective of historical context, the formation of ideas about spiritual entities as derivatives of socio-economic development, the work of F. Nietzsche "Beyond Good and Evil", Z. Freud's "The Future of an Illusion" - all this contributed to the destruction of previous values. In Nietzsche's nihilistic conception, we find a critique of prior morality and a direct contrasting of this position with the previous humanistic intentions of classical philosophy. After Freud's discovery of the realm of the unconscious the philosophy has faced another problem: the unconscious contains such a negative energy that the conscious is almost unable to keep it within the limits of traditional decency. According to Freud, the unconscious is a dark cellar in which evil, dark forces rage. And the presence of such an argument is another blow to the previous concept of humanism, in which man was given certain qualities by nature: the "divine" reason, the desire for justice, the ability to recognize good and evil, etc.

All this contributed to the fact that in the early 20th century philosophy underwent a so-called "anthropological" turn, resulting in a peculiar movement - philosophical anthropology, which began to study man both in terms of his natural inclinations and in the context of his spiritual transformations. 
In the end, it expanded the boundaries of knowledge about biological, genetic, historical, socio-economic, socio-cultural, psychological dependence of a person, and therefore it is more difficult for him to determine the main intensity of his life, and thus his humanistic orientation. Such dependence undermines the moral and ethical basis of the individual's values. In addition, the very reality of the twentieth century with its two world wars and cruelty testified in favour of the thesis about the anti-human nature of man. The old problem of ancient Chinese philosophy: "Man by nature is good or evil?" suddenly came to a clear decision: "man by nature is evil". All grounds for allegations of humanism and of the moral progress of mankind have disappeared. As E. Neumann, a representative of depth psychology, wrote about this, "our epoch has another distinctive feature: the collective manifestation of evil contained in man on a scale not known by any of the earlier eras of world history"1. So, it appears quite logical to conclude that during the twentieth century a man seems to be definitely degrading or in a "moral crisis".

In addition, depth psychology has shown the imperfection of the position of the human Ego, its overweight in the formation of worldview. It turned out that the role of consciousness in the formation of vital landmarks was exaggerated. Moreover, such an orientation to rational positive values alone entails some danger. Because as soon as reality ceases to conform to these attitudes, one tends to rush in the opposite direction and begins to see only the negative aspects of being everywhere. Therefore, the idea of a new humanism in the middle of the twentieth century is again on the agenda, and is being addressed by representatives of existentialism, "humanistic psychology", the Frankfurt School, and others.

\section{The Concept of Humanism in Existential Philosophy and in Humanistic Psychology}

The ideas of existentialism, as a certain trend, which advocated the uniqueness of the individual, became popular in the mid-twentieth century in response to the total alienation, convincingly described by the representative of the Frankfurt School. In particular, H. Marcuse, in his work "OneDimensional Man", pointed to a comprehensive process of dehumanization that touched all aspects of human life. The widespread regulation and dominance of technological rationality leave no room for personal development. Moreover, the influence of society is so effective that man seems to be dissolved in the social. As Marcuse noted, "Our society distinguishes itself by conquering the centrifugal social forces with

\footnotetext{
${ }^{1}$ Neumann E. (1999) Depth Psychology and a New Ethic. - St. Petersburg, Progress. - P. 23.
} 
Technology rather than Terror, on the dual basis of an overwhelming efficiency and an increasing standard of living"2. The author consistently substantiates the opinion that a man in such a society does not have his own needs and interests. In his view, "Indeed, in the most highly developed areas of contemporary society, the transplantation of social into individual needs is so effective that the difference between them seems to be purely theoretical" 3 .

The same trend was pointed out by another representative of the Frankfurt School E. Fromm, who wrote that "like a cog in the production mechanism, a man becomes a thing and loses human qualities"4. As a result, a person loses his activity, becomes indifferent to everything, loses interest in life. Human passivity is one of the hallmarks of total syndrome, which Fromm calls "alienation syndrome." That is, dehumanization is becoming a widespread phenomenon in a technology-oriented society.

Therefore, the general conclusion made by the representatives of this school was that the Western technologically advanced society adversely affects the person suffering from this dehumanization. Hence, it is quite legitimate to pose the question of how this total alienation can be overcome. H. Marcuse proposed the "Great Refusal", that is, when everyone has to say "No!" to the whole system of public oppression. E. Fromm proposed to cultivate "radical humanism" in society. But overall, their diagnosis was fairly straightforward: society is sick, and radical measures are needed for it recovery.

Existentialists, generally agreeing with the above diagnosis, offered their own way of overcoming total alienation and their vision of the humanistic transformation of man. In particular, J.-Sartre's work "Existentialism is a Humanism" (1947) draws a distinction between classical humanism and its existentialist version. This distinction manifests itself in the process of comparing perceptions of the essence of man: if previous humanism regarded man as the highest value, as a being destined to produce positive benefits for all mankind, then existentialism proceeds from the thesis that there is no predetermined essence in man, or in other words "existence precedes essence." That is, man does not have a constant, nature-defined kernel of self. Man is what he does himself, what his original choice is. The person is constantly in the making. This is his absolute feature: to constantly be on the move, to design himself. Humanism here is that if a person continually transcends, goes beyond himself (the so-called phenomenon of intentional

\footnotetext{
${ }^{2}$ Marcuse H.(1966) One-Dimensional Man. - Boston. - P. X.

${ }^{3}$ Ibidem, p. 10-11.

${ }^{4}$ Fromm E. (1996) Revolution of Hope // Contemporary Foreign Social Philosophy. - Kyiv, Lybid. - P. 146.
} 
orientation), then human subjectivity is essential for human existence in the world. It is a reminder to a person that the meaning of the world goes through him, that he is responsible for everything that happens around him. As Sartre noted, "When we say that man chooses himself, not only do we mean that each of us must choose himself, but also that in choosing himself, he is choosing for all men",5.

Thus, humanism is manifested here in the fact that man assumes responsibility for everything created by him. In the process of initial choice, it is the person who creates values. And if a person assumes this responsibility and makes his choice, then that choice contains a humanistic potential. Sartre insists that a priori a man cannot choose (at the time of a spontaneous "initial choice") something that can have negative consequences.

The initial choice is always a good one. For Sartre, "To choose to be this or that is to affirm at the same time the value of what we choose, because we can never choose evil. We always choose the good, and nothing can be good for us without being good for all"6. Sometimes this Sartre's statement is interpreted in a vulgar way, and then it seems that he doesn't understand the obvious: what is good for me may be bad for another. However, Sartre and the existentialists generally insist that this choice is pre-reflective and is at the very core of human existence. It is not a rational choice when we are hesitant in choosing between the best and the worst. It is an intentional choice of a person that does not go through the sphere of rational thinking. The choice should be made not on the basis of rational calculation, under the pressure of circumstances or predefined rules, but by recognizing that each individual is the creator of human values and that his primordial ("ontological") freedom is the basis of all values. It is in this choice that the existential nature of man manifests itself.

That is, it is humanism that manifests itself in the process of human selfformation, and not the result of predefined positive qualities of man.

M. Heidegger interprets this problem somewhat differently, although there are some related points. Defining the etymology of the word "humanitas", Heidegger indicates that the term appears in Ancient Rome in order to distinguish a Roman from a barbarian. And the renaissance of humanism during the Renaissance also bears the mark of contrasting "humanity" with the "inhumanity" of barbarians, or the previous inhumanity of scholasticism. This formulation of the question implies that there is some "humanity" as the "essence" of man. Or, as Heidegger points out, "the first humanism, namely, the Latin, and all the kinds of humanism that have emerged from that time up

\footnotetext{
${ }^{5}$ Sartre J.-P. (1996) L'existentialisme est un humanisme. Paris, Gallimard. - P. 22.

${ }^{6}$ Sartre J.-P. (1996) L'existentialisme est un humanisme. Paris, Gallimard. - P. 32.
} 
to the present presupposes that the most general "essence" of man is selfevident" ". If we try to clarify the "essence" and find out what this humanitas manifests, then the question arises about the "existence" of human being. That is, "man belongs to his essence, only insofar as it is existence, that is, a constant going beyond. Thus, in contrast to the previous metaphysics, which believed that it knew what the essence of man is, existentialism emphasizes that the essence of man is existence, a certain primordial incompleteness, openness of being.

But even in this sense, the intention of the previous metaphysics is still felt: it seems to us that when we say: "the existence of man is his substance," we supposedly find an adequate form for the definition of man. However, here we are told by the desire evoked by the previous philosophy to define something substantial, as something permanent, predetermined. Yet, existentialism emphasizes the fundamental difference between existence and any human traits. From this perspective, Heidegger even criticizes Sartre, who, turning the thesis of previous philosophy "essence precedes existence" to the opposite: "existence precedes essence," still seems to be in the thrall of the old paradigm of philosophy. In fact, according to Heidegger, there is no opposition of existence and essence: man is only to the extent he exists.

It turns out that there are no direction signs, no landmarks. Man is thrown into being, and he only has to heed the call of being. "A man in his beinghistorical essence is a being whose existence consists in pointing towards

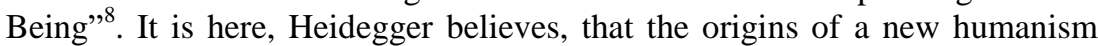
must be sought. "It is humanism that thinks humanity of a man as pointing towards Being". That is, Heidegger denies humanism in the metaphysical sense, and argues for humanism in service to the truths of being.

Thus, in existentialism, great hope was placed on the original intentional acts of man, and these acts form the basis of a new type of humanism. This idea of intentional acts of self-expression of human nature and of their humanistic nature was taken up by representatives of "humanistic psychology" (W. Frankl, K. Rogers, E. Fromm, etc.). In particular, W. Frankl's book "Man's Search for Meaning" further elaborates this idea. He notes that there are three basic "existentials" (synonymous with intentional acts - V.L.) in man, which have an intentional nature: freedom, spirituality, responsibility. K. Rogers, another representative of the same movement, also

\footnotetext{
${ }^{7}$ Heidegger M. Letter on Humanism // The Problem of Man in Western Philosophy. - M., 1988. (in Russian). - P. 321.

${ }^{8}$ Heidegger M. Letter on Humanism // The Problem of Man in Western Philosophy. - M., 1988. (in Russian). - P. 338.

${ }^{9}$ Heidegger M. Letter on Humanism // The Problem of Man in Western Philosophy. - M., 1988. (in Russian). - P. 338.
} 
believed that a man has an intention for self-expression, for self-actualization. He emphasized that this self-actualization is done on the basis of intentional acts, not on the basis of reason, rational calculations, willpower and so on.

However, this position has a certain ambiguity: if the basis of humanism is the very process of "existence", that is, the manifestation of pre-reflective intentional acts, then it is unclear where there is the boundary between the truly "human" in man and those manifestations of negative character ("bestial") which are also demonstrated by modern reality. Existentialists have eliminated the difficulty here by dividing human existence into "true" and "untrue". And if a person is in the mode of "true" being, the result of his intentional expression will be definitely positive. (Let us recall the words of J.-P.Sartre: "To choose to be this or that is to affirm at the same time the value of what we choose..."

Approximately the same context is proposed by E. Fromm division of human life into two modes of existence: "being" and "having". According to Fromm, the "being" modus is quite specific, since it cannot be reached by conscious choice. "Modus of being" is an analogue of true being, and "Modus of having" is a certain type of deviation from true existence. The characteristics of this "mode of being" are determined at the level of prereflective consciousness. It cannot be grasped on the basis of reflective thinking. It cannot be interpreted clearly. In relation to this, Fromm said: everything I say about it would be wrong. It can be understood only at some subconscious level.

Fromm thus explains his position: in the course of the development, humanity has lost its original contact with nature, and social life forms have adversely affected the individual, as a result of which man nowadays suffers from "alienation syndrome". The dramatic nature of the situation is compounded by the fact that neither at the level of social existence nor at the individual level did the person have the opportunity to avoid deformities and depressive states. Hence, the only possible way, according to Fromm, to find the lost quality of life and mental health is a radical transformation of personality through "humanistic" or existential psychoanalysis. We have an alternative: "either enlightenment or illness," Fromm wrote ${ }^{11}$.

However, in his opinion, it is the dramatic nature of this situation that will push people to choose a society with a humanistic orientation. Fromm's position here is presented quite radically: in almost all possible forms of

10 Sartre J.-P. (1997). Existentialism is a Humanism. - Retrieved from: https://learning.hccs.edu/faculty/david.poston/phil1301.80361/readings-for-apr-14/jean-paulsartre-existentialism-is-a-humanism/view (in English).

${ }^{11}$ Fromm E. (1992) Psychoanalysis and Zen Buddhism // Philos. i Sociol. Dumka . - No. 3. (in Ukrainian). - P. 15. 
worldview, due to their social involvement, people behave inappropriately. They are constantly under pressure, experiencing various forms of alienation. This involuntarily evokes a thought that the social form of life is the cause of all inadequate reactions of the individual. (By the way, existentialism also insisted that social reality was alien or even hostile to humans).

In order to counteract the negative impact of the social, Fromm proposes to turn to existential psychoanalysis. Moreover, it is not a traditional psychoanalysis with its setting on the treatment of deviations, but on the contrary, it is a philosophical doctrine, which aims to help a person to open a new world view and achieve full existence. It is a certain "art of living" that can be mastered only after a long and complicated process of selftransformation. Fromm compares it to the process of transformation experienced by a man who has entered the path of "enlightenment" in Buddhism.

In comparing existential psychoanalysis with Buddhism, Fromm formulates some conditions under which radical transformation of personality is possible. Noting the shortcomings of the Freudian understanding of the unconscious as a cellar in which dark forces are imprisoned, Fromm supports $\mathrm{K}$. Young's idea of the need to bring the unconscious to the level of consciousness, seeing this as an opportunity to reveal the productive forces of the individual.

\section{Grounds for New Ethic and Humanism Offered by Representatives of Depth Psychology}

E. Neumann, a follower of the analytical psychology of K. Young, offered his understanding of the moral crisis of the 20th century man. In his opinion, the crisis is connected with the fact that in our time the old ethic and its methods of solving moral problems were destroyed. Moreover, he tried to prove that the old ethic not only ceased to correspond to the reality of the new age, but also lost its effectiveness as a mechanism for adapting the individual to collective values. The concept of "old ethic" Neumann understood as the general moral precept according to which the world appears as split into two parts: good and evil, light and darkness, holy and sinful. There is a constant struggle between them, which ultimately ends with the victory of good. However, evil is constantly reviving, and like the mythical Hydra, new and new heads grow out of it. Humankind has found itself in a paradoxical situation: although the higher powers of darkness are not capable of overcoming the forces of light, there is also no evidence that the latter will ever overcome evil in this world.

In this ethic, it is quite right to assume that we are on the side of good and are constantly fighting evil. However, since the values of the old ethic are 
"absolute" in nature, and they do not involve any compromise (i.e., not adapted to the reality of personal being), then adaptation to these values is one of the most difficult tasks in the life of any man, while playing an important role in his adaptation to collective values ${ }^{12}$.

The researcher proposes to consider how traditional ethic, formed on ancient Greek and Judeo-Christian principles, solved the problem of combating evil. First of all, it was thought that the embodiment of moral virtues is the image of a sage or saint, pious or orthodox advocate of the law, hero or person who is able to possess himself. In any case, good (in any of its hypostases) acts as an absolute value that must determine human behaviour. It was accepted that such an ideal can only be achieved through the consistent and systematic elimination of all negative qualities. That is, the moral structure of the individual, his perfection is formed through a conscious emphasis on certain positive values. Conversely, all that is incompatible with the moral ideal must be eliminated. Such elimination occurs either by suppressing negative qualities or by repressing them.

When suppressing ego consciousness eradicates all the negative. In traditional ethic, this happens through austerity, the restraint of natural impulses, the sacrifice of something, through some suffering. Suppressed instinctive reactions continue to play a role, but through their denial. In the process of applying this method, it is constantly improving, but, characteristically, the suppressed content and its components retain a conscious connection with the Ego (we are aware of our sinfulness).

Unlike suppression, repression is characterized by the fact that the rejected, incompatible with the dominant value of the content and components of the individual lose their connection with conscious structures and become unconscious or forgotten. In such cases, the Ego is unaware of their existence $^{13}$. Although, according to Neumann, as shown by the so-called depth psychology, they lead quite active lives. Despite the fact that on a conscious level they do not show themselves, after all, sooner or later, the displaced content somehow makes itself known, and this leads to more tragic consequences than in the case of suppression. As for an individual, this manifests itself in the form of neurosis, as for the collective, then here also we have something similar to mass psychosis. In particular, psychologists such as K. Jung, E. Neumann, W. Reich, and others tried to comprehend such phenomena.

\footnotetext{
${ }^{12}$ Neumann E. Depth Psychology and a New Ethic. - St. Petersburg, 1999. (in Russian). P. 35.

${ }^{13}$ Neumann E. Depth Psychology and a New Ethic. - St. Petersburg, 1999. (in Russian). P. 33.
} 
That is, E. Neumann believed that this analysis that seems legitimate solely for the individual could be applied to collective communities. ("The individual (and his fate) serves as a prototype of the collective" 14 . Accordingly, the same mechanism of ethical principles that takes place in the field of individual psyche, works in the field of social relations. For the sake of social order stability, the collective imposes certain values on the individual. As E. Neumann noted, "the role of authority through which the old ethic inflicted its commandments on the individual was fulfilled by "conscience"15. "Conscience" appears as something that compels a person to reconcile his actions and aspirations with collective values and attitudes. Psychologists distinguish between "conscience" and "inner voice" (the latter characterizes the individual characteristic of human being). The purpose of traditional ethic is to develop in the individual a set of values that are acceptable to the society. Therefore, the individual is split into what is unique to him and what is collectively sanctified. The old ethic is based on the struggle between good and evil, light and darkness. And only one party is accepted. If the human ego fully identifies itself with collective values, then it has a "clear conscience". But this leads to exaggeration of one of the sides (Ego), to its "inflating". Or, as Neumann wrote, "Ego imagines itself to be in complete harmony with those values of its culture which are accepted as positive. Ego feels itself to be the bearer no longer simply of the conscious light of human understanding but also of the moral light of the world of values" ${ }^{\prime 16}$. This results in different types of fanaticism (holiness, orthodoxy, legitimacy, fascism, communism, etc.).

The suppression and repression we talked about earlier also work here. When suppressed, "conscience" shows its force in the form of guilt, when repressed, this feeling is unconscious. However, guilt is driven out of the system by both the individual and the collective. This happens by way of the Shadow projection. That is, the Shadow is perceived not as something own, though another, but is transferred to an external object and is perceived as a foreign object. Here we can recall the classic example of such a transference, namely, the finding of a "scapegoat", to which all the sins are transferred (in Judaism, they sent it into the desert, to Azazel). But in the modern world we have similar examples of shifting our troubles to another (to an enemy, to a neighbour, to an opponent, etc.).

\footnotetext{
${ }^{14}$ Neumann E. Depth Psychology and a New Ethic. - St. Petersburg, 1999. (in Russian). P. 28.

${ }^{15}$ Neumann E. Depth Psychology and a New Ethic. - St. Petersburg, 1999. (in Russian). P. 33.

${ }^{16}$ Neumann E. Depth Psychology and a New Ethic. - St. Petersburg, 1999. (in Russian). P. 39.
} 
E. Neumann is based here on the teachings of K. Jung, according to which the structure of the psyche consists of several archetypes, which form the primordial schemes, foretypes of fantasies, representations and the so-called collective unconscious. The central archetype is that of "Self", which embodies an integrated, holistic personality structure. However, along with it there are other archetypes - "Persona", "Shadow", "Anima", "Animus". In our analysis, the archetype "Shadow" is of paramount importance, because it is the embodiment of the hidden, suppressed, inferior and guilty part of the personality that reaches its roots to the animal world, the world of our ancestors, and thus embodies the historical layer of the unconscious. Shadow formation occurs in childhood, when the child is confronted with certain prohibitions and is forced to repress or suppress those traits that are forbidden in this culture. However, from time to time they make themselves known, and this poses a challenge for both the individual and humanity as a whole. Therefore, dealing with these unconscious cravings and instincts creates a particular problem for different ethical teachings.

E. Neumann traces the process of becoming a new ethic in the context of the development of consciousness from its original form (where the unconscious and mythological dominated the Ego) to the formation of the consciousness of the individual, which is carried out with the help of the collective and its instructions, receiving from it the "existing values". After all, the Ego, as the centre of this consciousness, usually becomes the bearer and representative of the collective values existing at that time. That is, if in the first stage of this process the influence of the Ego was almost insensible, and the collective form of consciousness dominated the individual, then the role of the Ego further increases, and accordingly the split between the conscious part of the psyche and the sphere of the unconscious is outlined. E. Neumann notes that because of this, two mental systems are formed in the personality, one of which remains completely unconscious, and the other, with the active support of the Ego and the conscious mind, becomes an important organ of the psyche. The unconscious system in K. Jung's psychoanalytic concept was called "Shadow" and the other was called "Persona" or external personality. In a civilized society, the formation of the "Persona" is a necessary process that adapts the individual to the requirements of a particular historical age.

E. Neumann believed that the very approach of old ethic, when the world is split into two parts, one of which is supported and the other is depreciated and discarded, is the cause of modern problems. The contents driven out of consciousness become regressive, they accumulate and gradually create tension that can lead to negative consequences. As Neumann wrote, "the more dogmatically the old ethic is imposed on individuals and societies, i.e. the 
stronger the influence of conscience, the more radical the repression becomes, and the greater the gap between consciousness with its value identification and the unconscious, which in the form of compensation takes the opposite position"17. After all, the danger is the way in which old ethic seek to eliminate the sense of guilt and ease the tension in the sphere of the unconscious. Even wars and revolutions, according to Neumann, are manifestations of the unconscious forces that have accumulated in society and need to be discharged ("Wars serve as a correlate of old ethic, since they clearly manifest the activation of the unconscious, shadowy side of the collective" ${ }^{\prime 18}$. Similarly, the fight against heretics, political opponents, enemies of the people, etc., is a struggle against our fears, vulnerabilities and insecurities. That is, we are trying to find a way to identify ourselves with ideal values. The easiest way is to destroy the Shadow in the form of a "scapegoat". Various segments of the population are offered to the role of the victim of this scapegoat psychology: the morally defective, ethnic minorities, foreigners, etc. For greater efficiency, the punishment ceremony usually has a solemn appearance. As Neumann noted, "Church and state representatives are involved in executing sentences against the unfortunate victims of scapegoat psychology, feeling a sense of pride that their "conscience is clear". The elimination of "external evil" has always brought clear relief to both the individual and the collective" ${ }^{\prime 19}$. Of course, all this can be explained as the development of culture and civilization. However, Neumann insists that it is this scapegoat psychology that has played a catastrophic role in the history of mankind, since any people who are convinced of their divinity believe that they work for the benefit of all mankind.

Therefore, in his opinion, the old ethic should be responsible not only for the negation of the shadow side, but also for the splitting of the individual, which in this case occurs. Splitting leads to an unconscious sense of inferiority, which is offset by the tendency to exaggerate self-justification. The Shadow projection becomes systematic and manifests itself in the form of fear of persecution by other people or the whole world.

We can say that the old ethic is the ethic of conscious attitude, the ethic of "clear conscience". That is why it is a partial ethic because it does not take into account the influence of the unconscious. That is why the old ethic has

${ }^{17}$ Neumann E. Depth Psychology and a New Ethic. - St. Petersburg, 1999. (in Russian). P. 48.

${ }^{18}$ Neumann E. Depth Psychology and a New Ethic. - St. Petersburg, 1999. (in Russian). P. 57.

${ }^{19}$ Neumann E. Depth Psychology and a New Ethic. - St. Petersburg, 1999. (in Russian). P. 53. 
proved its inability to solve the urgent problems of morality of modern $\operatorname{man}^{20}$. Another danger of the old ethic is that it does not take into account the compensatory relations between the conscious and the unconscious, which, according to Neumann, is the main cause of the current crisis in the social sphere. He points out that in the last one and a half century we have a breakthrough of the dark unconscious part of our psyche into society. There is interest in various forms of "evil" or experimentation with the "demonic". In the view of Neumann's, the new ethics is to consider an integral human having concatenated both individual and collective, as well as both the conscious and the unconscious.

\section{CONCLUSIONS}

Therefore, while comparing the position of the existentialists with the findings of the depth psychology researchers', it is necessary to point out the fundamental difference in spontaneity being interpreted as an authenticity criterion for an individual behaviour.

Existentialism is rooted in the initial thesis of a human being's key characteristic being humaneness, the latter emerging in the process of continuous self-transcendence, while approaching to the authentic existence. The criterion for such an authenticity can imply a spontaneous non-reflective behaviour. However, as Neumann's analysis demonstrated, both orientation at the values of the conscious, and spontaneous dark sides ("Shadow") manifestation, can be detrimental.

This particular issue gives rise to the idea of the new ethic, which will be free from the shortcomings of the previous ethic and will be able to respond appropriately to the challenges of today. The way out of this split position means changes of the basic ethical settings and negation of the absolute nature of goodness, holiness, heroism, as well as trying not to fight with the Shadow, while making attempts of understanding it as an inner archetype. In the new ethical situation there should be presented various coexisting elements, both constructive and destructive, instinctive and spiritual, religious and atheistic. The main requirement of the new ethic is not "goodness" of an individual, but rather his psychological independence, health and integrity. Or, as Neumann wrote, "in this case, the values of the new ethic can be formulated as follows: whatever leads to wholeness is "good"; whatever leads to splitting is "evil". Integration is good, disintegration is evil" $"$.

\footnotetext{
${ }^{20}$ Neumann E. Depth Psychology and a New Ethic. - St. Petersburg, 1999. (in Russian). P. 75 .

${ }^{21}$ Neumann E. Depth Psychology and a New Ethic. - St. Petersburg, 1999. (in Russian). P. 130.
} 
Thus, in this case, the process of manifesting the "humanistic" nature of man is associated with the mastery of art to come into direct contact with reality, bypassing rationalist filters and psychological protections. That is, the new paradigm of humanism is connected with the development of a certain attitude to reality, where intentional acts, pre-reflective actions, direct contact with reality are the basis of human activity.

\section{SUMMARY}

The article is aimed at the transformation of the humanism principles in the context of the twentieth century realities when the previous ethical principles and rules mostly lost their prescriptive power and effectiveness.

Certainly, the whole situation was not such a straightforward one. Thus, exactly during this period there have been attempts of finding a new basis for humanism. In particular, Jean-P. Sartre in his work Existentialism is a humanism (1946) distinguishes between the classical humanism and its existentialist version, and tried to find out a new reason for this humanism. E. Fromm, the "humanistic psychology" representative, also sought to justify a new humanism. According to Fromm, the only way to find a lost human existence and mental health lies within the radical transformation of an individual through "humanistic" or existential psychoanalysis.

In this respect, this approach differs radically from the position of E. Neumann, the follower of so-called depth psychology who investigated the causes of the moral crisis having impact on a human being during the twentieth century. In his view, the crisis lies within the fact that the old ethic and the methods of solving moral problems tend to collapse nowadays. In particular, he tried to prove that the old ethic has not only ceased to meet the realities of modern times, but lost effectiveness as a mechanism aimed at adapting an individual to the collective values.

The way out of this situation means changes of the basic ethical settings and negation of the absolute nature of goodness, holiness, heroism, as well as trying not to fight with the Shadow, while making attempts of understanding it as an inner archetype. The old ethic should be responsible not only for the denial of the shadow-formed side, but for the dissociation of personality resulting from the situation. In the new ethical situation there should be presented various coexisting elements, both constructive and destructive, instinctive and spiritual, religious and atheistic. The main requirement of the new ethic is not "goodness" of an individual, but rather his/her psychological independence, health and integrity. 


\section{REFERENCES}

1. Fromm E. (1996) Revolution of Hope // Contemporary Foreign Social Philosophy. - Kyiv, Lybid.

2. Fromm E. (1992) Psychoanalysis and Zen Buddhism // Philos. i Sociol. Dumka . - No. 3. (in Ukrainian).

3. Heidegger M. (1988) Letter on Humanism // The Problem of Man in Western Philosophy. - M., Progress. (in Russian).

4. Neumann E. (1999) Depth Psychology and a New Ethic. St. Petersburg, (in Russian).

5. Sartre, Jean-Paul (1996). L'existentialisme est un humanisme. Paris, Gallimard. (in French).

Information about the author:

Vitalii Liakh,

Doctor of Philosophical Sciences, Professor, Head of the Department of History of Foreign Philosophy, H.S. Skovoroda Institute of Philosophy of NAS of Ukraine ORCID: orcid.org/0000-0003-4683-0838 
DOI https://doi.org/10.36059/978-966-397-190-2/46-73

\section{THE CHRISTIAN PEACEBUILDING PHILOSOPHY}

\section{Nikolay Nesprava}

\section{INTRODUCTION}

At the beginning of the XXI century, mankind faces with new topical threats. Whereas, in the second half of previous century the study of security concerns revolved around a nuclear confrontation in a bipolar world, where peace was provided by a "balance of fear", now the complex problems of terrorism, separatism, hybrid wars, information warfare, and cyber-attacks are on the agenda. And conflict that destabilizes Ukraine and has led to thousands of victims is especially painful for us. So, peacebuilding is the challenge of our age and urgent task for our country.

We have entered an era of conflict that is taking new forms, and spreading in ways that are outstripping the power of the international community to respond. The dramatic changes taking place in the world are forcing scholars to rethink the secular approaches to considering the age-old dilemma of war and peace that have dominated international relations theory for more than two centuries, and to return the gaze to those spiritual primary sources of understanding ontological, anthropological, and axiological dimensions that are contained in the Christian doctrine. To understand the difference in opponents' approaches, we should refer to an illustration of the antithesis between them, which Professor of Government at Harvard University R. R. Tuck gives an example:

Rhetoricians by their trade were commited to taking the interests of their city as the starting point of their arguents, for they were appealing to political bodies whose raison d'être was the welfare of their particular community. Philosophers were equally committed to a wider view, and to addressing people to non-political context, as were their Christian successors ${ }^{1}$.

The great philosophers have been thinking about the causes of war and ways to achieve eternal peace from ancient times. The synthesis of these considerations led to the formation of a special direction of philosophy, called "philosophy of peace". "In the philosophy of peace, - A. Capto points out, - peace is understood as a concerted relationship, quietude, and absence of hostility, war and quarrels"2.

\footnotetext{
${ }^{1}$ Tuck R. (1999). The Right of War and Peace: Political Thought and the International Order from Grotius to Kant. New York: Oxford University Press, p. 227.

${ }^{2}$ Kapto A. S. (1990). Filosofiya mira: istoki, tendentsii, perspektivyi [The Philosophy of Peace: Sources, Trends, Prospects]. Moscow: Politizdat, p. 12. (in Russian).
} 
This interpretation reflects the essence of peace in the wide social sense. Respectively, experts of Alliance for Peacebuilding note:

Peacebuilding is ultimately an elastic concept, encompassing a wide range of efforts by diverse actors in government and civil society at the community, national, and international levels, to address the immediate impacts and root causes of conflict before, during, and after violent conflict occurs. Peacebuilding ultimately supports human security - providing freedom from fear, freedom from want, and freedom from humiliation ${ }^{3}$.

In a narrow practical sense, peacebuilding is understood as activity that aims to resolve injustice without resorting to deadly violence and to transform the cultural and structural conditions that generate deadly or destructive conflict. And in a broad philosophical sense, peacebuilding is understood as measures to eradicate the causes of potential conflicts between social actors and maintain a sustainable peace.

In this chapter the peacebuilding is considered precisely in this broad philosophical sense. At the same time, the study of Christian peacebuilding philosophy, focusing on the idea of peace as a promising goal, aims to formulate the problem that we must solve in Ukraine in the near future.

\section{The main peace studies' concepts: why state power, economic benefit and international law do not build peace sustainably}

Sustainable peace proposals include many different aspects. Generally, main directions of peacebuilding theory can be grouped into military-political, socio-economic, international legal and spiritual-ethical concepts. In the process of developing knowledge about the peace, scholars have given priority to one or another area of scientific analysis of the problem.

The military-political recipes of ensuring peace by striking a balance of power go back to Thucydides, and through Machiavelli's political doctrine, are reflected in the paradigm of realism and neo-realism, that had reached its apogee during the Cold War as a "balance of fear" strategy. But even the most powerful nuclear arsenals could not save the Soviet Union from its decay. It was overwhelmed by the crisis of spirituality, that was reflected in the politics of double and sometimes triple moral standards. However, the so-called "real politik" concept has many supporters, both among politicians and scholars up to now. For example, Russian social philosopher V. Ksenofontov believes that political content, determined primarily by the dominant economic, political and military elite of states, is crucial necessary to understand the essence of

3 What is Peacebuilding? (2018). Alliance for Peacebuilding. Retrieved from: https://allianceforpeacebuilding.org/what-is-peacebuilding/ (accessed 10 January 2020). 
peace ${ }^{4}$. Similarly, Trump and Putin speak out recently. But such a etatistical approach, that is characteristic of realism, does not reflect the complex picture of modern world. In this world, the role of states is blurred, and the threat of war between states or blocs has been replaced by terrorist explosions, separatism, hybrid and information wars and cyberattacks, and its sources lie hidden in the gray areas of non-state structures. Ukrainian political scientist A. Kostyrev argues, that "in a network society, a hierarchical state power based on the legitimate use of violence is inferior to a communication power formed by horizontal ties between actors who share common spiritual values" ${ }^{\prime 5}$. Since, the confrontation in modern conflicts shifts into the spiritual and informational sphere, so much so, in the process of peacebuilding, the militarians and politicians must give priority to the "catchers of men", as Christ called the apostles (Matt. IV, 18-23).

The origins of socio-economic concept of peace can be found in the writings of Aristotle, but it is most emphasized in the theories of Marxism and neo-Marxism. In the scope of this concept in 1964, J. Galtung developed the theory of "positive peace", that is widely accepted now. In this theory, peace is not just the absence of war, peace must include freedom from hunger and oppression, but also serve its purposes - economic development and social justice. Following this logic, the developers of "cooperative peace" theory argue that in an era of economic globalization, the peace must globalize also. But there are several counterarguments to the apologists of this theory. First, in accordance with I. Wallerstein's theory, the gap between the "core" countries, its population is called the "golden billion", and the poorer "periphery" countries is steadily increasing. Secondly, the facts indicate that economic and cultural globalization really means westernisation and unification, that caused a reaction in the form of aggressive nationalism and jihad. Third, even close economic relationships are not guarantee against intrusion by "partners". It has happened in Libya, Syria and, unfortunately, in Ukraine.

Consequently, contrary to F. Fukuyama's predictions, the Western model of combining a market economy with liberal democracy could not become a universal recipe for peace. The reason of this statement is discovered in the fact that, without a religious and ethical basis, the natural right to consumption transforms the society from a moral and spiritual formation into a secularized "society of consumption", and its crisis we have observed since 2008. It is

\footnotetext{
${ }^{4}$ Ksenofontov V. N. (2008). Mir kak sostoyanie obschestva [Peace as a state of society]. Moscow: Russian Academy of Public Administration, p. 42. (in Russian).

5 Kostyrev A. (2013). Kommunikatsionnaya vlast: sotsialnyie seti kak instrumentyi noopolitiki [Communication power: social networks as tools of noopolitics]. Political design in the space of social communications, vol. 2, p. 54. (in Russian).
} 
impossible to achieve harmony in market relations without the self-restraint that results from religious education. Therefore, international market turns into series of conflicts with increasing tension.

Although international treaties have been known as a peace agreement since the time of Hammurabi, the international legal concept of peace originates from G. Grotius. In his treatise "On the Law of War and Peace", the Dutch philosopher suggested ways of sanctioning and deterring war, that would be based on rational principles. Ideally, he saw the international community governed less by Christian authority than by negotiations and treaties between states. The long-known definition of "just war" has found its scientific justification within this theory. But, as British writer J. Gittings points out, "totalitarian regimes demanded its protection just as likely as liberal or democratic governments; and both sides in the Crimean, Boer and two World Wars insisted that their war was just" ${ }^{\text {"6 }}$. It should be emphasized that we have heard a similar argument to justify US intervention in Iraq and Russia's annexation of Crimea. Thus, no wonder that I. Kant claimed that the international law doctrine of just war only provided a fig leaf for aggression. In the same context, we are increasingly seeing a conflict between the fundamental principles of the UN, that were intended to ensure peace on the planet. The double standards in interpreting the principles of the right of indigenous peoples to self-determination and territorial integrity of states, as well as the principles of defence of human rights and sovereignty of states, serve as justifications for aggression. And the practical irresponsibility of the UN Security Council member states is opening their hands. This is a factual confirmation of F. Dostoevsky's opinion that if God is not there then all is permissible. In this case, it is mean that there is no God in the souls of the leaders of the aggressor states and therefore no treaties are an obstacle to them. Obviously, that all endevors to justify the wars of some kind of legal basis are caused by political interests.

Therefore, it is logically justified to pay particular attention to the spiritual-ethical concept of peace, sometimes called idealistic. Philosophers, who develop this concept, focus on the ethical aspects of peace and believe that the moral re-education of people in the spirit of humanism is capable to achieve a sustainable universal peace. American philosopher W. Hamblet notes, that discussion between apologists of realistic and idealistic theories has begun from Socrates' dispute with the disciples over the question of justice in human societies by establishing a model of the battle between power and

${ }^{6}$ Gittings J. (2015). Philosophy and Peace. The Question of Peace in Modern Political Thought, ed. by T. Koivukoski \& D. E. Tabachnick. Waterloo: Wilfred Laurier University Press, p. 36 . 
persuasion ${ }^{7}$. But Christian peacebuilding philosophy looks on this problem much more wider and deeper.

\section{Ontological, Anthropological, Axiological and Praxeological Measurements of Christian peacebuilding philosophy}

The ideas of peacebuilding are an integral part of the worldview systems of ancient philosophy, Confucianism, Hinduism and Buddhism. But the origins of the spiritual and ethical concept of peace must be found in the Bible narratives, which formed the basis for the formation of ontological and axiological approaches to peacebuilding in Judaism, Christianity and Islam. The Priestly Blessing ends with significant words: "May God lift up his face onto you and give you peace" (Numbers 6:2426).

It is important to pay attention that Christian philosophy represents the peace at the same time as a basic category of being and as an all-embracing complex value. As the great Christian humanist Desiderius Erasmus said, "peace is the mother and nanny of all the good that humanity has" ${ }^{8}$. Without peace, all other human aspirations lose their meaning, "because if there is everything that is valued in this world, wealth, health, wife, children, home, family ... but there will be no good - peace, what is the use of all blessings, pleasure which will stop the war?"9 Therefore, peacebuilding determines the whole meaning of human being, for with peace "the fruits of the Spirit appear: love, joy, goodness, longsuffering, and all the benefits of the Apostle" (Gal. 5:22).

\subsection{Human Life and Dignity: for What Peace is Build}

The right to life is the ontological basis of peacebuilding. The secular statement in this regard is quite simple: the individual's right to life is conditioned only by the fact that he is a human. But it is noticeable that this formula lacks the evidence base. After all, the human right to life is not conditioned by its biological nature, because it is clear to everyone that it is fundamentally different from the rights of animals and other environmental objects that "green" stand for. A more persuasive approach is based on the Biblical conception of man as God's creation. The essensial peacebuilding

\footnotetext{
${ }^{7}$ Hamblet W. (2017). Harvesting the Human: Force and Persuasion in Human Societies. Concerned Philosophers for Peace Newsletter Online. Retrieved from: http://peacephilosophy.org/325/wendy-hamblet-harvesting-the-human-force-and-persuasion-inhuman-societies (accessed 12 January 2020).

${ }^{8}$ Quoted by Gittings J. (2015). Philosophy and Peace. The Question of Peace in Modern Political Thought, p. 28.

${ }^{9}$ Gregory of Nyssa, st. (1863). O blazhenstvakh. Slovo 7 [About bliss. Word 7]. Complete set of Works. Mosow: V. Gotie's typography. P. 455. (in Russian).
} 
principle is based on this approach exactly, it was proclaimed in the sixth commandment of the law of God: "Thou shalt not kill!", which was communicated to men by Moses 3.5 thousand years ago. As Russian lawyer P. Barenboim points out, "for the sake of completeness to understand the meaning of this commandment, it should be added that, according to the prophets, one who wishes to die to another person, who does not help the poor and sick, who does not live with others in harmony and in peace, and, on the contrary, treats others with hatred, envy and malice, engulfs with others quarrels and fights, offends others. All the wicked and the strong who offend the weak are sinning against the sixth commandment" ${ }^{\prime \prime}$.

Practically all religious teachings proceed from this principle. However, only in Christianity human life is an absolute value. Christianity, unlike other Avramist religions, considers a person not only as a unique creation of God, created by Him in His own image and likeness, but also as a creature, in which God embodied one of his hypostases in the image of Christ, that is, became humanized. Christianity argues that God not only created human, but also became a man in the image of the Savior, without dissolving man in Himself. Having taken upon himself human sins, the Savior opened before everyone not only the prospect of eternal life, but also pointed out the possibility of atonement for sins through repentance already in this earthly life. Sincere repentance in the face of the Lord, according to Christian doctrine, can lead even an inveterate sinner to the path of the true and will be granted Salvation. American religious scholar R. Traer notes that "the right to life, which is respected as the first of natural rights, essentially emerges from the value, which God gives for the life of human by one's creation and salvation" $"$.

Therefore, in accordance with the Christian dogma, any murder, no matter what motives people use to try to justify it, is a violation of the Higher Purpose of returning a human to God. And since the violation of God's commandment is evil, therefore, any murder is evil, and because a war is a massacre, it is a thousandfold evil, which cannot be justified. Attention should be paid to the fact how much Christian axiology and teleology differ from pagan and even Muslim ideologies in this respect. Paganism and Islam actively promote military prowess as a priority value and motivate their believers to military exploits,

\footnotetext{
${ }^{10}$ Barenboym P. D. (2016). Bybleyskiy moment philosophiyi prava [Biblical moment of the philosophy of law]. Mediaglagol. Pravoslavnyi obrazovatel'nyi portal [Mediaglagol. Ortodox educational portal]. (in Russian). Retrieved from: http://mediaglagol.com.ua/book/bibleyiskiyi_ moment_filosofii_prava_pd_barenboyim. (accessed 15 January 2020).

11 Traer R. (2009). Christian Support for Human Rights. Religion and Human Rights. Retrieved from: http://religionhumanrights.com/Religion/Christian/christian.fhr.htm (accessed 14 January 2020).
} 
promising eternal bliss in the Valhalla to perished Vikings, and guaranteeing the status of holy martyrs and a place in paradise, where gurians will appease them, for shahids. It is true that in the Middle Ages the Popes also tried to manipulate the feelings of believers and promised the forgiveness of sins to crusaders, opening them the way to the salvation. But in general, Christianity as a spiritual system does not motivate people to war, but to peacebuilding. For in fact, Christ did not promise bliss to warriors. On the contrary, He equated the peacemakers with the sons of God, proclaiming: "Blessed are the peacemakers, for they will be called the sons of God" (Matt. 5:9).

Christian Churches proceed from the premise that greater co-operation in the field of conflict resolution, including in the Donbas, must be an universal recognition of the high value of the human personality, and an understanding that any war threatens to destroy God's creation and life. The All-Ukrainian Council of Churches and Religious Organizations have proclaimed:

When the lives and health of some people become instruments by which others seek to gain certain political preferences and benefits, it will not only diminish the value of the lives of the hostages and captives themselves, but it is a challenge to the rights and freedoms of the whole world, because the pain and humiliation of any human being is the tragedy of all mankind ${ }^{12}$.

The problem has become even more complicated in connection with the development and using of hybrid warfare methods, one of the main elements of which is the manipulation of public opinion and the substitution of values. For the solution of this problem at the ideological level scholars should refer to the concept of human dignity.

Human dignity as a spiritual basis of peacebuilding philosophy logically derives from the faith in Christ the Savior. As the Dutch researcher of human rights and jurisprudence B. Fortman proclaims, "Christ - God and man - is the deepest source and guarantee for the dignity of the human person"13. However, Christian axiology of human rights distinguishes the value of life from the value of human dignity. Life is given by God, and dignity is acquired by human. The person becomes dignified by doing goodness.

In order to understand the significance of this category for the philosophy of peacebuilding, it is important to emphasize that in the Christian tradition

12 Zvernennya Vseukrayins'koyi Rady' Cerkov i Religijny'h Organizacij shhodo stanovlennya spravedly'vosti v Ukrayini [The Statement of the All-Ukrainian Council of Churches and Religious Organizations on the establishment of justice in Ukraine]. Kyiv, 17 May 2016. (in Ukrainian). Retrieved from: http://vrciro.org.ua/ua/statements/465-uccrostatementjustice-court-judge-ukraine (accessed 16 January 2020).

${ }^{13}$ Fortman B. (2011) Religion and Human Rights: A Dialectical Relationship. e-International Relations. 05 Dec. Retrieved from: http://www.e-ir.info/2011/12/05/religion-and-human-rights-adialectical-relationship/ (accessed 14 January 2020). 
the concept of "dignity" has primarily a moral meaning, and a notion what is worthy, and what is not worthy is closely related to the moral or immoral actions of a person and to his or her internal soul's state. An individual acquires dignity in the pursuit of good. On the contrary, when an individual chooses evil, freedom of choice leads him or her to self-destruction and damages a human dignity and public peace. Immutable and non-manipulated principles of good are given to human in Gospel commandments. As the great Christian saints pointed out, "the one who creates the peace, creates it through the transformation of evil, that is, through the change and bringing of evil for the better" ${ }^{\prime 4}$. Recall that, according to the theologians, the fight against evil is the highest purpose of human, and then the commandment, according to which the Lord calls the peacemaker the son of God, will be better understood. The one of the Great Christian Teachers - Gregory of Nyssa emphasized:

To the one who prevented the calamity of war the Lord gives two gifts at once: one is the reward by which he becomes a successor of God, and the other is the feat, because if for such a thing and nothing it was necessary to have in hope, then peace in itself for those who has a mind, is more expensive than any care about it ${ }^{15}$.

But Christian Teachers have pointed out that peacebuilding requires not only hard spiritual work for the sake of good to achieve one's dignity, but also for such moral behavior that does not affect the dignity of another person. Human cannot show one's dignity by humiliating another person. This leads to the first formulation of the categorical imperative, sometimes called the "universalizability principle": "Act only according to that maxim whereby you can at the same time will that it should become a universal law"16. In fact, this imperative is the philosophical formalized commandment of Christ, who proclaimed in the Sermon on the Mount: "Therefore, whatever you want others to do for you, do also the same for them, for this is the Law and the Prophets" (Matt. 7:12). And it is not accidental, because I. Kant was convinced that moral faith in God, in the Kingdom of God as the highest good, in personal immortality is not based on hypotheses and imaginary evidence of theoretical reason, but it is based on an unconditionally true conclusion, which is drawn from the nature of morality and human nature as a moral being. While liberal theories absolutize the dignity of the individual, Christian interpretation points to its relational nature. Primordial dignity,

\footnotetext{
${ }^{14}$ Basil the Great, st. (2008). Beseda 9. O tom, chto Bog nie vinovnik zla [Conversation 9, That God is not the culprit of evil. Works, Vol. 1. Moscow: Blagovest. P. 356. (in Russian).

${ }^{15}$ Gregory of Nyssa, st. (1863). O blazhenstvah. Slovo 7 [About bliss. Word 7]. P. 458.

${ }^{16}$ Kant I. (1993). Grounding for the Metaphysics of Morals. Trans. by J. W. Ellington, ( $3^{\text {rd }}$ ed.). Indianoapolis: Hackett. P. 30.
} 
conditioned by the creation of human in the image and likeness of God, is not a fixed constant. The social essence of human demands to constantly nurture this virtue, making conscious free choice for the benefit of good towards others and an environment. The Christian conception of peacebuilding formulates the human dignity as a priority of duties towards his neighbors in compare with their own rights. Apostle Paul proclaimed: "Let nobody seek his own, but each one [benefits] of another ... for what would my will be judged by another's conscience?" (1 Corinth. 10: 23-24, 29). Kant relied on Christian postulates and emphasizes that duty is the highest form of moral behavior.

The problem is how human dignity, as a personal pursuit of good, relates to the dominant social views. A history is full of examples when those who sought reconciliation were accused as traitors, and those who sought war were celebrated as heroes. And the dramatic Ukrainian realities oblige us to recollect Ecclesiastes' direction: "The quiet words of the wise are more to be heeded than the shouts of a ruler of fools. Wisdom is better than weapons of war, but one sinner destroys much good" (Ecclesiastes 9:17-18). Great Christian peacemaker and humanist Pope John Paul II accented on the problem of human dignity's relativity:

A human receives from God his essential dignity and, with it, the ability to exalted himself above any social order in search of truth and goodness, however, it is due by the social structure in which he lives, also by the education and the environment ${ }^{17}$.

And so, human must again and again comprehend the difficult art of earthly human co-existence as a ministry, purpose and duty. In this context, attention should be paid to the fact that such a basic value of the peacebuilding philosophy as justice flows logically from the Christian understanding of human dignity as a moral obligation to God and people. And B. Fortman states: "Unquestionably then, the fellowship that human beings are called upon to establish is not just a matter of envisioning the others as free and equal creatures but also of doing justice and living together in peace"18.

\subsection{Justice as Love and Charity: by What Peace is Build}

The Christian worldview platform has enabled thinkers to identify the teleology of justice. According to Thomas Aquinas, the goal of justice is to guide our actions in accordance with the common good. Exactly this goal focuses all peacebuilding efforts. In doing so, the praxeological aspects of this

${ }^{17}$ John Paul II (1991) Encyclical Centesimus annus. Ukrainian Catholic University: Institute of Religion and Society. (in Ukrainian). Retrieved from: http://irs.ucu.edu.ua/dzherela/sotsialnientsikliki/ivan-pavlo-ii-centesimus-annus-1991. (accessed 20 January 2020).

${ }^{18}$ Fortman B. (2011) Religion and Human Rights: A Dialectical Relationship. 
activity are revealed through Christian ethical principles. F. Bacon, the founder of modern philosophy, in fact returning to the Gospel guidelines, stated that "justice is not to do to others what you do not wish for yourself". In an extramural dispute with Machiavelli and Hobbes, he made the conclusion of the peacebuilding philosophy that "it is only through the presence of justice a human is a god, not a wolf for others" ${ }^{\prime 19}$. In the context of our study, it will be interesting to note that this scholar, who is considered an opponent of scholasticism and an apologist for empiricism, insisted that "superficial philosophy inclines the mind of human to godlessness; the depths of philosophy turn human's minds to religion" ${ }^{20}$. Kant believed that justice is the basis and purpose of human life. He argued that "if justice disappears, life on earth will no longer have any value" 21 .

It should be noted that in the Christian peacebuilding philosophy justice as an axiological category acquires a deep ontological content. Christian philosophy gives an interpretation of justice as a human's reflection of the supreme God's law. Traer emphasizes that "Christians assert that because God loves all people, all people have rights and the corresponding duties to respect the rights of all others" ${ }^{, 2}$. In order to understand the peacebuilding essence of the Christian ontology of justice, it is important to note that, although its roots extend back to the Old Testament, Christian approaches to justice are fundamentally different from the laws of Moses. The Old Testament contains one of the oldest known formulations of the talion principle - the phrase "eye for eye, tooth for tooth" was quoted from Exodus (21: 23-27), and also was repeated in Leviticus (24:20), which not only justifies violence but commits to it actually. This principle underlies the tradition of blood revenge exactly. However, a revenge has not a measure, one revenge generates another, another - a third, which can lead to the complete destruction of the genus. That is, after all, that an evil will win and a death will dominate.

But in Christ, who "death trampled upon death", humanity has found a chance for salvation. The charity professed by Christianity is related to the principle of equal repayment, according to the dialectical law of "denial of denial". In the Sermon on the Mount, Christ proclaimed: "You have heard that our parents were told: 'Eye for eye, and tooth for tooth'. But I tell you, don't resist an evildoer. On the contrary, if anyone slaps you on your right cheek,

${ }^{19}$ Bacon F. (2014). Introductory dedication of "An Advertisement Touching a Holy War" to Bishop Lancelot Andrews. The Essays and Counsels, Civil and Morales. B\&R Samizdat Express. P. 356.

${ }^{20}$ Bacon F. (2014). Of Atheism. The Essays and Counsels, Civil and Morales. B\&R Samizdat Express. p. 231.

${ }^{21}$ Kant I. (1993). Grounding for the Metaphysics of Morals. P. 265.

22 Traer R. (2015). Christian Support for Human Rights. 
turn the other to him also" (Mtt. 5: 38-41). As applied to peacebuilding, it is perhaps one of the Savior's most paradoxical teachings. Does it mean indulging the evil of violence actually? Not at all! The point is that the peacemaker must suppress the bitterness in himself and find the strength to forgive the offender. Thus, Christian justice means the victory of good over evil essentially. The Apostle Paul explains what his Teacher said precisely: "Do not be overcome by evil, but overcome evil with good" (Rom. 12:21). That is why forgiveness and charity have become distinctive markers of the Christian peacebuilding philosophy.

They help to find a way out of the stalemate known in politics as the syndrome "Our boys died not in vain". This syndrome manifests itself in Ukraine. But now in our country it is so painful that it is better to turn to the example that the Israeli historian and philosopher Y. N. Harari describes. In 1915, Italy entered the First World War on the side of the Entente. State proclaimed as its goal the "liberation" of Trento and Trieste "unjustly" held by Austria-Hungary. Italian politicians shook the air with fiery speeches. Hundreds of thousands of Italian volunteers rushed to the front with shouts: "For Trento and Trieste!" They thought it would be a walk. A glorious adventure turned into a bloody massacre. But it was difficult for politicians to tell parents that their son had died in vain, and it was even more difficult for father and mother to say this to themselves. After all, if the Italian national myth was a lie, then they have to admit that the death of their son is absolutely meaningless. Few people can do it. Therefore, politicians sent soldiers into a second attack and laid down thousands more. And then they again chose the continuation of the war - because "our boys died not in vain". By the end of the war, nearly 700 thousand Italian soldiers were killed and more than half a million were injured, but Italy never received the territories it claimed ${ }^{23}$. Obviously, it was enough to recall the Gospel commandments about the pricelessness of human life in order to avoid the outbreak of war. And if politicians made a criminal mistake, and the war nevertheless began, then people should promptly and unconditionally accept the Christian principle of forgiveness to the leadership in order to stop the snowball of bloody victims. We must to draw relevant historical parallels and to conclude that our boys did not die in vain - they taught us a harsh lesson that must never be forgotten - a violating the Savior's commandments is evil for which reckoning follows.

There is no doubt that philanthropy is a distinctive feature of Christianity. In the Gospel, we find not only a clear commandment: "Love your neighbor

${ }^{23}$ Harari Y. N. (2016). Homo Deus: A Brief History of Tomorrow. London: Harvill Secker. Pp. 351-353. 
as yourself" (Matt. 22:39), but also a more complicated cognitive model: "Love your enemies, bless those who curse you, who hate you, and pray for those who offend you and lead you, so that you may be the sons of your Father in heaven" (Mat. 5: 43-46). It is useful to address to the conclusions of P. Yurkevich, the founder of the "philosophy of a heart", to understand the peacebuilding potential of the Christian awareness of justice. This Ukrainian thinker argued:

With the highest moral development, a person obeys the commandments of love, which inspires him to sacrifice his personal benefits for the benefit of others, for the benefit of the common. In justice and love are the most durable conditions for peace among people, for the foundation of common friendship and brotherhood between them. And so those who awaken in a human these moral requirements are peacebuilders essentially ${ }^{24}$.

It is important to note that it is through the notion of love that Great Christian Teachers revealed the meaning of the concept of "peace". In their opinion, the opposite of love is hatred, anger, irritation, envy, malice, hypocrisy, disaster of $\operatorname{war}^{25}$. In general, the philosophy of peace, and even wider - the whole social philosophy, in its Christian interpretation is a philosophy of love essentially. This clearly demonstrates the statement of the Russian thinker S. Frank:

The great moral principle: "love your neighbor as yourself", even if in a weakened, diminished form of simple discretion in another person "neighbor", "like yourself", perceiving him as "you", i.e. as a creature, which connected with me and identical with "me", with whose fate my fate is connected - there is an unshakable and eternal foundation, without that society is unthinkable; and all sorts of newest "individualism", no matter what it preaches and no matter how much relative truth it contains, cannot violate or annul this first and fundamental principle of the public ${ }^{26}$.

Thus, Christian philosophers argue that love is the anthropological essence of peacebuilding, because it restrains the "natural" envy and hatred of

${ }^{24}$ Yurkevich P. D. (1860). Mir s blizhnim kak usloviye khristianskogo obshchyezhytiya (Trudy Kyivskoy Duhovnoy Academiyi) [Peace with the neighbor as a condition of a Christian cohabitation (The Works of the Kyiv Theological Academy)]. Philosophskiye proizvyedyeniya [The Philosophical Works]. Moscow: Znaniye, 1990. P. 74. (in Russian).

${ }^{25}$ Gregory the Theologian, st. (1912). Slovo 6, O mirie, skzannoie v prisutstvii ottza poslie priedydushchiego molchaniia po sluchaiu vossoiedinieniia monahov [Word 6, About the Peace, was said in the presence of the father after the previous silence, on the occasion of the reunion of monks]. Tvoreniya izhe vo svyatykh ottsa nashego Grigoriya Bogoslova, Arkhiepiskopa Konstantinopolskogo [The Works of Our Holy Father Gregory the Theologian, Archbishop of Constantinople]. vol. 1. Sankt-Peterburg: Petr Soykin Publ. (in Russian).

${ }^{26}$ Frank S. L. (1925). Religioznyie osnovy obshchestvennosti [Religious Foundations of the Public]. Put' [The Way], no. 1, pp. 12-13. (in Russian). 
individuals, on which pointed the attention Machiavelli and Hobbes and their successors from the 'political realists' camp. If force-based order in any case leads to conflict and disintegration of the constituent parts ultimately, and formal social treaty can't preserve the unity of warring individuals for a long time, then love, accompanied by forgiveness and repentance, is capable to unite even an offender and his victim. This approach paves the way not only for establishing harmony in society, but also for peaceful coexistence between states. It also provides guidelines for solving the complex international law dilemma of the relation between state sovereignty and a need for peace on the planet. As Tuck stresses:

Kant's intention was to show: it was not the case that one was caught between the Scylla of a world state and Charybdis of perpetual war. The central aspect of this claim was that the rules governing the relationship of modern states would be minimal in character, thinker (on Kant's account) that Hobbesian state of nature, but much thinner than those of a civil society ${ }^{27}$.

Christian definition of justice as ontological and axiological core of social relations is a distinctive feature of peacebuilding principles that interpret justice in terms of equality and solidarity. Thomas Aquinas, commenting the content of the assessment of social relations based on the criterion of justice, pointed out that an act is "just", if it is coordinated with another person by means of some equality ${ }^{28}$. In a special way, Christian humanity and solidarity are expressed in the words of St. Paul: "Does one member suffer, all members suffer from it? and when one member rejoices, all members rejoice with him" (Rom. 3: 37-38). Christian tradition requires not only to build the peace on a moral basis, but also through alms-deed, following the teachings of Apostle Paul: "By working, we must support the weak and remember the words of the Lord Jesus, for He Himself said: "It is more blessed to give than to take" (Acts 20:35). So, solidarity and subsidiarity are the fundamental principles of Christian peacebuilding philosophy.

Another fundamental principle of Christian peacebuilding philosophy non-discrimination - comes from moral values too. On this subject, the Christian tradition has a clear position. Christians believe that "God from the same blood has formed the whole human race for living all over the face of the earth" (Acts 17:26) and that in Christ "there is no Jew or Greek, there is no slave, nor free, no man, nor woman because you are all one in Christ Jesus"

27 Tuck R. (1999). The Right of War and Peace: Political Thought and the International Order from Grotius to Kant. P. 221.

${ }^{28}$ Thomas Aquinas, st. (2010). O spravedlivosti, vopros 91. Summa teologiyi [About a Justice, question 58. Summa Theologiae]: in 12 vol. Ed. by S. I. Yeremeyev. Kyiv: Nika-Centre, vol. VI. (in Russian). Retrieved from: https://azbyka.ru/otechnik/konfessii/summa-teologii-tom-6/ (accessed 19 January 2020). 
(Gal. 3:28). This fruitful source has to continue to nourish the value content of the human rights concept that is the bar of international peacebuilding system. Although in the Middle Ages the Church spread the demand to preserve peace only to Christian world and consecrated the crusades against the unbelievers as a divine deed, but even then the leading theologians defended the idea of peace as a universal value.

However, it should be noted that the problem of identity has been and remains one of the key issues in the peacebuilding. And Renaissance jurist and humanist Andrea Alciato's statement testifies to this:

When war is declared against Turks and Saracens, there are the rights of postliminium, and those taken in war become the property of the captors, but in is otherwise among Christians, for under the law of CHRIST all men are brothers, so that war between them is even worse than civil war; so there is no right of postliminium in this case ${ }^{29}$.

The events of the XXI century confirm that medieval religious intolerance and marginal ethno-nationalism, born in the XIX century, having experienced both fascism and communism, remain the main stimulators of conflict and are used by paranoid politicians to incite hatred and wars in a according to the well-known Rome empire's formula "divide et impera". However, Bible teaching provides the advice in this case: "They will beat their swords into plowshares and their spears into pruning hooks. Nation will not take up sword against nation, nor will they train for war anymore" (Isaiah 2:4; Micah 4:3). And it is necessary to accent that "the LORD examines the righteous, but the wicked, those who love violence, he hates with a passion" (Psalms 11:5).

\subsection{The Power for Peace: a Sword in the Saint's Hands}

In general, the problem of using violence against violence, also known as "the power for peace", is one of the most difficult in peace studies. Norwegian sociologis and founder of the discipline of peace and conflict studies J. Galtung distinguishes: a) a direct, or "hot" violence, which refers to acts that impose immediate harm on a given subject or group; b) a structural violence, which refers to the ways that systems and institutions in society cause, reinforce, or perpetuate direct violence; c) a cultural violence, which refers to aspects of culture that can be used to justify or legitimize direct or structural violence - the ways in which direct or structural violence look or feel "right" according to the moral fabric of society ${ }^{30}$. The measures which are provided in the plans of "negative peace", then - "positive peace" and

\footnotetext{
${ }^{29}$ Tuck R. (1999). The Right of War and Peace: Political Thought and the International Order from Grotius to Kant. P. 28.

${ }^{30}$ Galtung J. (1990). Cultural Violence. Journal of Peace Research, vol. 27, iss. 3, pp. 291-305. doi:10.1177/0022343390027003005.
} 
finally - "justpeace" (or "just peace") are used to curb the manifestation of these types of violence successively ${ }^{31}$. But from the standpoint of understanding the peacebuilding in a broad philosophical sense, the problem of the possibility of using violence to prevent conflict or to establish peace remains open. In the Old Testament violence is viewed not only as evil, but also as a necessary punishment for sin or just vengeance. On the contrary, the Christian ontological and axiological paradigm, recognizing the permissibility of violence to deal with the concrete manifestations of sinful evil in certain cases, proclaims non-violence as a moral obligation arising from Gospel commandments.

The Christian principles of nonviolence have found the most uncompromising expression in the L. N. Tolstoy's doctrine of non-resistance to evil by violence, in which he views evil as some chain reaction. Once occurring, evil engenders appropriate actions which, even if justified, are generally not contained within the framework of justice, it gives a rise to new evil, and on an even larger scale than before. Great Russian writer concludes that the determination to refrain from retribution for the harm done, including from the right to self-defense, is the only way to stop this devastating process. The main thing, in Tolstoy's opinion, lies not in the act of renouncing revenge, but in the clarified sense of love for all without exception, that moves the morally educated person. From the point of view of evaluating the practical application of this concept, American theologian and peacemaking researcher $\mathrm{T}$. Rynne recommends to refer to the political experience of Mahatma Gandhi, who adopted the concept of nonviolence found in the New Testament, in particular in the Sermon on the Mount, and made extensive use of social and political struggles in his strategy ${ }^{32}$. In modern philosophy of peace, this peace-making teaching of Christ has become the most complete form in the ideology of pacifism, which is justified by the belief in the moral unacceptability of war in principle. At the same time, in pacifism, spiritual and ethical guidelines are considered as the basis of the triad - scientific study of the problems of peace, education in the spirit of peace, and actions for the realization of peace (peacekeeping and peacebuilding).

It should be noted that opponents cast doubt on the allegations of pacifists about the onset of sustainable peace as a result of the perceived refusal of people, political structures and states from all forms of violence. The apologists of political realism are skeptical to the peacebuilding potential of the religious Renaissance, the spiritual perfection of humanity, the humanistic

\footnotetext{
${ }^{31}$ Galtung J. (2011). Peace, Positive and Negative. The Encyclopedia of Peace Psychology, American Cancer Society, pp. 23-54. doi:10.1002/9780470672532.

${ }^{32}$ Rynne T. J. (2008). Gandhi and Jesus: The Saving Power of Nonviolence. London: Orbis Books, p. 54-55.
} 
activity of state, public, and religious leaders ${ }^{33}$. But adherents of the spiritualethical concept point to the dialectical nature of the fight against the terror of war and the hope of an "era of charity". St. Augustine though convinced that it was more glory to end the war with one word than to kill people with the sword, but at the same time wrote:

Christian could use violence on behalf of his city as long as it was clearly recognized that it was deeply unfortunate duty brought about by a clear case of injustice in the world, and that violence was intended to protect those things in accordance with law by which peace and human society are preserved on the basis of such things ${ }^{34}$.

The Christian peacebuilding philosophy proposes its ontological and anthropological view of conflict nature as the starting point in solving the problem of violence. Christians believe that any conflicts are the result of connivance to sinful passions: "What is the source of wars and fights among you? Don't they come from your passions that wage war within you?"(Jas. 4:1). The Sixth Ecumenical Orthodox Council expressly defined sin as a disease of the soul, and conflicts, strife, crimes and wars with their tragic consequences are only external symptoms of this disease. Therefore, as the Church leaders emphasize, not only the external symptoms of this disease but also the disease itself - sin, must be eliminated in order to prevent crimes, ending wars and overcoming terrorism ${ }^{35}$.

As a surgeon uses a scalpel to remove a malignant tumor and can cause pain to the patient, so healing sin may require the use of force and cause suffering. And in this sense the expression of Christ "Don't assume that I came to bring peace on the earth. I did not come to bring peace, but a sword." (Mt 10:34), which is interpreted ambiguously, has to be understood. According to the Gospel, Christian philosophers say with certainty that the lifelong existence of evil does not mean that human should not fight it, moreover, this deed is human's divine purpose. This statement is the ontological basis of teleology of peacebuilding. It follows from the crucial conclusion of the Christian saints that the "not God fights against evil, but human!"36, because God created human for good.

${ }^{33}$ Koshin V. (1990). Filosofiya mira v yadernyiy vek [The philosophy of peace in the nuclear age]. Voprosyi filosofii [The Questions of Philosophy], no. 5, pp. 39-54. (in Russian).

${ }^{34}$ Augustine, st. (1943). Answer to Sceptics. Ed. by R. Arbesman. Trans. D. J. Kavanagh. New York. P. 74.

${ }^{35}$ Missiya Pravoslavnoi Tcerkvi v sovremennom mire [Orthodox Church's mission in the modern world]. VI Vsemirnyi Pravoslavnyi Sobor [VI World Orthodox Meeting], Shambezy, 26-28 Jan. 2016. (in Russian). Retrieved from: http://www.patriarchia.ru/db/print/4360988.html (accessed 18 January 2020).

36 Gregory the Theologian, st. (1912). Chudiesnyie pesnopieniia. Slovo 4, o mirie [The mysterious chants. Word 4, about the Peace. Tvoreniya izhe vo svyatykh ottsa nashego 
So, Christian thinkers argue that there is an essential differentiation between sinful and non-sinful violence. Relying on the position of the Christian ontological and axiological paradigm, we can offer the criteria by which violent actions should be classification as non-sinful accordingly to Christian peacebuilding philosophy. The violence, the genesis of which is ontologically linked to evil, can, however, be defined as non- sinful and have some justification from the standpoint of Christian axiology if: firstly, it has a character of warning or counteraction, and not revenge; secondly, it does not degrade the human dignity; thirdly, and most importantly, it is directed by the higher postulates of love, rather than by the struggle for material values, socio-political or religious ideals.

The Christian peacebuilding philosophy inferences that only victory over evil in one's soul opens the possibility for a person to use force adequately. Such a view, while affirming the rule of love in human relations, strongly rejects the idea of resisting evil by force ${ }^{37}$. Russian philosopher I. Ilyin wrote:

Who resists villains by force and sword must be purer and above his own struggle; otherwise he will not lead it and he will not finish it with victory, but it will seize him, distort his face and throw him away, broken, humiliated and vicious. Only the one who possesses himself, that is, his passions and his vision, can possess the power and the sword ${ }^{38}$.

The dramatic events in Ukraine confirm that real peace in society cannot be achieved without "killing the dragon" first and foremost in oneself. Great Christian teachers also pointed to this thesis in their time, based on the theistic ontology of the good developed by them. Gregory of Nyssa explained the importance of internal peacebuilding as a means of virtue:

Because good is not only what is delivered to others, so we call the peacemaker in the full sense that one who leads the rebellion of the flesh and spirit, and the interpersonal curse of nature in itself to peaceful consent ${ }^{39}$.

Yurkevich revealed in detail the Christian contents of peacebuilding as a human-building:

Grigoriya Bogoslova, Arkhiepiskopa Konstantinopolskogo [The Works of Our Holy Father Gregory the Theologian, Archbishop of Constantinople]. vol. 1. Sankt-Peterburg: Petr Soykin Publ. P. 25. (in Russian).

${ }^{37}$ Osnovy sotcialnoyi kontceptciyi Rus'koyi Pravoslavnoyi Tcerkvy [The Fundamentals of the Russian Orthodox Church's Social Concept] (2002). Kyiv: Information and Publishing Center of the Ukrainian Orthodox Church. (in Ukranian). Retrieved from http://www.patriarchia.ru/ua/ db/text/1207692.html (accessed 16 January 2020).

${ }^{38}$ Ilyin I. A. (1995). O soprotivlenii zlu siloiu [About resistance to evil by force]. Collected Works in 10 vol. Vol. 5. Moscow: Russkaia kniga. P. 217. (in Russian).

${ }^{39}$ Gregory of Nyssa, st. (1863). O blazhenstvah. Slovo 7 [About bliss. Word 7]. P. 466. (in Russian). 
In general, peace with people requires, as a necessary condition, that a person has to be in peace with himself, or that he has an inner peace of mind that is achieved by self-control, triumph over passions, obedience to the voice of conscience, and especially active devotion to the will of $\operatorname{God}^{40}$.

Thus, a peacebuilding is presented in Christian philosophy as the way to inner unity - to good. But it should be emphasized that in the interpretations of Christian thinkers, these efforts are represented as having not only ethical but also ontological content, because inner unity as deliverance from the temptation of evil and reunion with God, is a deification that opens the way of return to paradise.

While apologists of 'real politik' see the use or threat of violence as the only means of securing peace, and unable to see the long-term harmful effects of the principle si vis pacem - para bellum, supporters of a spiritual and ethical concept direct their peacekeeping efforts to eradicate true causes of wars and terrorism. The challenge is to act peacefully in a world where the principle of "peace through force" is used to resolve conflicts, and where "force" is mistaken for violence ${ }^{41}$ Christ gave the recipe of such actions in his time, when he escaped violence against a woman caught in adultery, which seemed legitimate but contradicted the spirit of mercy, with one phrase: "Let any one of you who is without $\sin$ be the first to throw a stone at her" (John 8:7).

Therefore, according to Christian moral philosophy, the sword can only be valid in the saint's hands. But since the height of the righteous can be attained only by individual spiritual cultivation, so group righteousness does not occur. Such claims of some social groups, parties, ethnos, or states have inevitably led to tragic consequences. But even now, people hear claims of "exclusivity" or "special mission" from the mouths of some "great nations" leaders. Thus, since group righteousness does not exist, and war or revolution is always a mass violence, so in the Christian philosophical spiritual sense a just violent social conflict is impossible. From a truly Christian point of view, not clouded by political interests, "holy war" and "revolution of dignity" are purely propaganda definitions that are devoid of moral content.

But at the same time, Christian philosophers have introduced a clear differentiation of responsibility for violence between those who obey orders and those who act on their own free will. In this case st. Augustine gave a clear explanation:

${ }^{40}$ Yurkevich P. D. (1860). Mir s blizhnim kak usloviye khristianskogo obshchyezhytiya. P. 76. (in Russian).

${ }^{41}$ Harris I. (2006). Peace Studies between the Two Infinities. Newsletters of the Concerned Philosophers for Peace, vol. 26 (2). Retrieved from: http://peacephilosophy.org/94/peace-studiesbetween-infinities-by-ian-harris (accessed 18 January 2020). 
A soldier, who kills the enemy is acting as an agent of the law, so he can easily perform his duty without inordinate desire (libibo). Furthermore, the law itself, which was established with a view to protecting the people, cannot be accused of any inordinate desire... [But as for someone who defends his own life, for example against a highway robber], I do not see how they can be excused, even if the law itself is just. For the law does not force them to kill; it merely leaves that in their power. They are free not to kill anyone for those things which can be lost against their will, and which they should therefore not love [i. e. their earthly life ${ }^{42}$.

This logic also implies a clear subsidiarity of responsibility between simple executors of orders (laws) and those who orders (or makes laws). So, a soldier, who does his duty on the battlefield even kills an enemy, is a hero, opposite, a politician, whose actions led to war and who orders to kill, is a criminal. The Nazis' atrocities were recognized as crimes by the Nuremberg Tribunal and their organizers were executed, but the destruction of Dresden, Hiroshima and Nagasaki as a result of massive or nuclear bombings lays as indelible spot of moral disgrace on the conscience of British and American politicians, though they did not violate the law. And if the positive results of peacebuilding are largely driven by the victory of each person over evil within oneself, then it applies to those who are endowed with power to a greater extent. John Chrysostom stated:

Truly the king is the one who conquers anger, and envy, and voluptuousness, submits all to the laws of God, keeps his mind free and does not allow the passion for pleasure to prevail over the soul. He would rule over people easily according to divine laws, so that he would be instead of a father for his subordinates, treating cities with all meekness ${ }^{43}$.

In the same time, Gregory the Theologian warned:

Otherwise, the greater evil will happen, than more a large number of people he will rule over, because the vice that spreads in many is more significant than the vice that dwells on one ${ }^{44}$.

${ }^{42}$ Augustine, st. (1993). On Free Choice of the Will. Ed. and trans. by T. Williams. Indianoapolis: Hackett. P. 25.

${ }^{43}$ John Chrysostom, st. (1898). Sravnenie vlasti, bogatstva i preimushchestv tsarskikh s istinnym i khristianskim lyubomudriem monasheskoy zhizni [The Comparison of the King's Power, Wealth and Advantages with the True and Christian Philisophy of Monastic Life]. Polnoie sobranie tvoreniy svyatitielya Ioanna Zlatousta [Complete collection of the works of St. John Chrysostom]. Vol. 1, Book 1. Sankt-Petersburg: Sankt-Pet. Theological Academy. Pp. 125, 129. (in Russian).

${ }^{44}$ Gregory the Theologian, st. (1912). Slovo 3 [Word 3]. Tvoreniya izhe vo svyatykh ottsa nashego Grigoriya Bogoslova, Arkhiepiskopa Konstantinopolskogo [The Works of Our Holy Father Gregory the Theologian, Archbishop of Constantinople], vol. 1. Sankt-Peterburg: Petr Soykin Publ. Pp. 518-519. (in Russian). 
The Ukrainian realities demand that truly peaceful people in the Christian sense of this definition, for whom peace is not only a political slogan, but the main internal unconditional and indispensable spiritual need, should be involved into the governance at all levels and in all regions.

\subsection{Value Dialogue: How Peace is Build}

In the process of peacebuilding, peace is not only a goal, but also a unifying value, and all other values, including religious, national or class identities, must to step back to it. Those social actors who advocate other priorities - such as past and present crusaders or jihadists, communists or Nazis - objectively serve the war. It is important to emphasize that the value priorities of Ukrainians are completely in line with the Christian axiological series, which was described above. According to a sociological poll conducted by the Gorshenin Institute in cooperation with the Friedrich Ebert Foundation, "peace" is the highest value for Ukrainian citizens (56.6\% of respondents), next come "value of human life" $(42.7 \%)$ and "human rights" $(33.3 \%)^{45}$. Obviously, that peacebuilding dialogue should be developed around these values exactly. Because, as Kostyrev argues, "shared values determine the potential for communication, in other words, the more commonality between the subjects, the faster they will reach understanding and the deeper it will be. The effect of trust as a necessary condition for social interaction arises in the process of communication exactly in the area of social actors' value frameworks' intersection" 46 .

The synergetics of the peacebuilding process is that, on the one side, the vision of peace as a common future, is the foundation of a peaceful dialogue, and, on the another side, this value dialogue opens up the prospect of a constructive transition from the chaos of war to the order of peace. As Fortman stresses, "the moral grounds for a conviction upon which responsible behaviour have to be constantly nurtured on the basis of a worldview shared by those concerned" ${ }^{47}$. Thus, we move to such a crucial component of peacebuilding praxeology as value communication. It should be emphasized that communication differs from other information processes because it aims to reach a certain community, that determines its peacebuilding potential. For

45 Internet-portal Dyvys' [Look]. 2017, 26 Oct. (in Ukrainian). Retrieved from: https://dyvys.info/2017/10/26/najbilshoyu-tsinnistyu-dlya-ukrayintsiv-ye-myr-najmenshoyupovaga-do-inshyh-kultur/ (accessed 20 January 2020).

${ }^{46}$ Kostyrev A. G. (2013). Ukraina: bufer ili forum? Mezhtsivilizatsionnaya kommunikatsiya kak geopoliticheskaya funktsiya Ukrainyi [Ukraine: buffer or forum? Inter-civilization communication as a geopolitical function of Ukraine]. LAP Lambert Academic Pablishing. ISBN 978-3-659-38256-7. P. 12.

${ }^{47}$ Fortman B. (2011) Religion and Human Rights: A Dialectical Relationship 
Christians, the foundation of such communion is unity in the Church of Christ through the sacrament of communion. From here it is clear that the Christian dimension of communication has profound content. It is expressed in the commandment: "Love the Lord your God with all your heart, and with all your soul, and with all your mind, and with all your strength" (Mk. 12:30, Mt. 22:37). Frank pointed to this meaning of Christian communication precisely, when he stated:

Service to God, carried out consciously or unconsciously, by hearsay, tradition and habit, is actually the basis of the whole social life of a person, outside of which it is generally unthinkable: it is expressed in the idea of a moral obligation that both the individual and society have equally ${ }^{48}$.

Yurkevich also relied on Christian values, considering the problem of communication as a means of achieving harmony in society:

A heart as bodily, soul and spiritual essence of human seeks good, fraternal communication. In this moral state, human destroys the sharp distance between himself and his neighbor, respects human dignity in all persons, respects others' rights and performs their duties, becomes able to sacrifice, forgive and cover others' weaknesses by love in the name of Christ $^{49}$.

Therefore, the communicative component of peacebuilding, which exists in the form of open discussion, along with impartial thought and critical thinking, presupposes the priority of higher spiritual values.

An example of such communication is the inter-denominational Christian ecumenical dialogue, which discusses the world's pressing problems of peace. The content of this communication is determined by a common value platform built on the three pillars of the Gospel - a love, charity and respect for the dignity of each person as God's creation. No wonder communication between Orthodoxy and Catholicism is called the dialogue of charity. This example serves as an guide to overcome all kind of hostility and, as a result, the cessation of wars and the victory over terrorism. In addition to its own example of humility and virtue, Church leaders and Christian volunteers are actively involved in helping the victims of armed conflicts, as well as helping to establish peaceful negotiations between the antagonistic parties. At the present stage, the situation in the Middle East, first of all in Syria, the armed

\footnotetext{
${ }^{48}$ Frank S. L. (1925). Religioznyie osnovy obshchestvennosti [Religious Foundations of the Public]. P. 24. (in Russian).

${ }^{49}$ Yurkevich P. D. (1990). Serdtze I yego znacheniye n duhovnoy zhyzni chelovyeka, po ucheniyu Slova Bozhiya. Philosophskiye proizvyedyeniya. (A heart and its meaning in the spiritual life of man, according to the teaching of the Word of God. Philosophical works. Moscow: Znaniye, pp. 226-227. (in Russian).
} 
conflict that breaks Ukraine and counterterrorism are the main subjects of the negotiations.

At the same time, it is important to emphasize that, although the surge of jihadism and the revitalization of ISIL have emerged as the main motivating factor for intensifying the dialogue between Orthodox, Catholics and Protestants, Christians do not regard Muslims as enemies, but rather seek for co-operation with Islam. For example, in a joint statement by Pope Francis and His Holiness Patriarch Cyril:

The serious problems facing the world today require the solidarity of all goodwill. Thus, we also recognize the importance of continuing a constructive dialogue with Islam based on mutual respect and friendship. Inspired by shared values and strengthened by genuine brotherly feelings, Muslims and Christians are called to cooperate for the sake of justice, peace, and respect for the dignity and rights of each person ${ }^{50}$.

Paying tribute to the bloody problems of the Middle East, it should be emphasized that it is of utmost importance for us to pay attention to how the high clergy of the Christian world propose to put an end to the war in Ukraine. The Ecumenical Patriarch Bartholomew and Pope Francis clearly defined the essence of the Christian approach to peace building in Ukraine:

We also remember all the people who experience the sufferings of war. In particular, we pray for peace in Ukraine, a country of ancient Christian tradition, while we call upon all parties involved to pursue the path of dialogue and of respect for international law in order to bring an end to the conflict and allow all Ukrainians to live in harmony ${ }^{51}$.

Therefore, in accordance with the principles of the Christian peacebuilding philosophy, establishing a broad public dialogue in Ukraine around such values as human right to life, human dignity and justice are the defining conditions for peace. And not only now along the line of collision and in the Donbass after its reintegration, but also all over Ukraine, understanding peacebuilding as an achievement of social harmony. As the All-Ukrainian Council of Churches and Religious Organizations notes:

All society and every citizen, whether politician or religious figure or media representative, should foster public peace and harmony, avoid hostility in their statements, seek ways of reconciliation through dialogue and mutual

${ }^{50}$ Sovmestnoe zayavlenie Papyi Rimskogo Frantsiska i Svyateyshego Patriarha Kirilla [Joint statement by Pope Francis and His Holiness Patriarch Cyril]. Habana, 13 Feb. 2016. (in Russian). Retrieved from: http://www.patriarchia.ru/db/text/4372074.html (accessed 22 January 2020).

${ }^{51}$ Ecumenical Patriarch Bartholomew and Pope Francis Sign Joint Declaration. Istanbul, 30 Nov. 2014. Retrieved from: https://www.patriarchate.org/-/ecumenical-patriarch-bartholomewand-pope-francis-sign-joint-declaration?inheritRedirect=true (accessed 22 January 2020). 
forgiveness. We ask that Ukrainian society be more tolerant. more compassionate and just to all its citizens without exception ${ }^{52}$.

The practical value of this work is contained in the possibility of using principal approaches and methods of the dialogue of charity to overcome armed violence, religious and nationalist extremism and to reconcile the warring parties. This task is especially urgent for the Ukrainian society.

\section{CONCLUSIONS}

The military-political, socio-economic, and international legal concepts could not create a reliable theoretical foundation for ensuring sustainable peace, because they overlook the role of human as a moral being in the process of peacebuilding. In modern conditions, when this role is growing rapidly, the appeal to the spiritual foundations of peacebuilding, which were developed within the framework of Christian philosophy, is productive.

The peacebuilding is an essential core of Christianity. From the ontological and axiological positions of the Christian peacebuilding philosophy, a war cannot be justified, a war cannot be a dignity deed, a war cannot be fair. Peacebuilding has universal value, only it is a truly dignity and just destination of human and society as a whole. Christian philosophy, defending the supremacy of spiritual factors over material as a condition of moral and social exaltation of human, regards the Gospel commandments as an invariable foundation of peacebuilding. Christian thinkers have shown that peacebuilding is the highest virtue as a manifestation of love and charity.

They consider peacebuilding primarily as humanbuilding, and argue that conflicts, strife, crimes and wars with their tragic consequences are external symptoms of sin as a spiritual illness. So, Christians believe that only spiritual perfection can eliminate not only the external symptoms of this disease, but also the disease itself and to return human to God. Based on the Christian peacebuilding philosophy, we can conclude that to prevent evil through violence means to prevent sin, but to take revenge by violence for evil means to commit sin.

All conditions of peacefully co-existence are based on values that create by Christian philosophy: non-violence is based on the human right to life, autonomy - on the human dignity, awareness - on the understanding of justice as love and charity, and communication - on the openness to peaceful value dialogue.

${ }^{52}$ Zvernennia Vseukrainskoi Rady Tserkov I Relihiinykh Orhanizatsii Shchodo Utverdzhennia Myru Ta Postupu Ukrainskoho Suspilstva [The All-Ukrainian Council of Churches and Religious Organizations Appeal on Promoting Peace and the Progress of Ukrainian Society]. Kramatorsk, 02 Nov. 2016. (in Ukrainian). Retrieved from: http://vrciro.org.ua/ua/statements/ 475-uccrostatement-on-peace-in-ukraine (accessed 22 January 2020). 
The content of Christian philosophy - the right to life and respect for the dignity of every human being as the creation of God, justice as a derivative of love and charity, equality, solidarity, non-discrimination and dialogue - is the spiritual foundation of UN principles of peace co-existence and determines the humanistic orientation of international law for peacebuilding. These principles are crucial for a philosophical understanding of the prospects of Ukraine's exit from the current acute socio-political crisis.

\section{SUMMARY}

The article deals ontological, anthropological, axiological and praxeological measurements of Christian peacebuilding philosophy. The author critically analyzes the content of the military-political, socio-economic and international legal concepts of ensuring peace and concludes that they could not create a reliable theoretical foundation for ensuring sustainable peace. He demonstrates that Christian philosophy represents the peace as a basic category of being and as an all-embracing complex value. Herewith, the right to life is the ontological basis of peacebuilding. Human dignity as a spiritual basis of peacebuilding philosophy logically derives from the faith in Christ the Savior. The author insists that an interpretation of justice as charity and forgiveness is an axiological core of Christian peacebuilding philosophy and gives the Christian philosophers' arguments that show love as the anthropological essence of peacebuilding. Paper accents that accordingly to the Christian peacebuilding philosophy only victory over evil in one's soul opens the possibility for a person to use force adequately. The author argues that the Christian approach to peacebuilding implies the development of a value dialogue between social actors, and cites as an example the Christian dialogue of charity as a response to the challenges of wars and terrorism.

\section{REFERENCES}

1. Augustine, st. (1943). Answer to Sceptics. Ed. by R/ Arbesman. Trans. D. J. Kavanagh. New York: Oxford University Press.

2. Augustine, st. (1993). On Free Choice of the Will. Ed. and trans. by T. Williams. Indianoapolis: Hackett.

3. Bacon F. (2014). Introductory dedication of "An Advertisement Touching a Holy War" to Bishop Lancelot Andrews. The Essays and Counsels, Civil and Morales. B\&R Samizdat Express. Pp. 351-362.

4. Bacon F. (2014). Of Atheism. The Essays and Counsels, Civil and Morales. B\&R Samizdat Express. Pp. 225-248.

5. Barenboym P. D. (2016). Bybleyskiy moment philosophiyi prava [Biblical moment of the philosophy of law]. Mediaglagol. Pravoslavnyi obrazovatel'nyi portal [Mediaglagol. Ortodox educational portal]. 
(in Russian). Retrieved from: http://mediaglagol.com.ua/book/bibleyiskiyi_ moment_filosofii_prava_pd_barenboyim. (accessed 15 January 2020).

6. Basil the Great, st. (2008). Beseda 9. O tom, chto Bog nie vinovnik zla [Conversation 9, That God is not the culprit of evil. Works, Vol. 1. Moscow: Blagovest. (in Russian).

7. Ecumenical Patriarch Bartholomew and Pope Francis Sign Joint Declaration. Istanbul, 30 Nov. 2014. Retrieved from: https://www.patriarchate.org/-/ecumenical-patriarch-bartholomew-and-popefrancis-sign-joint-declaration?inheritRedirect=true (accessed 22 January 2020).

8. Fortman B. (2011) Religion and Human Rights: A Dialectical Relationship. e-International Relations. 05 Dec. Retrieved from: http://www.e-ir.info/2011/12/05/religion-and-human-rights-a-dialecticalrelationship/ (accessed 14 January 2020).

9. Frank S. L. (1925). Religioznyie osnovy obshchestvennosti [Religious Foundations of the Public]. Put' [The Way], no. 1, pp. 11-25. (in Russian).

10. Galtung J. (1990). Cultural Violence. Journal of Peace Research, vol. 27, iss. 3, pp. 291-305. doi:10.1177/0022343390027003005.

11. Galtung J. (2011). Peace, Positive and Negative.The Encyclopedia of Peace Psychology, American Cancer Society, pp. 23-54. doi: $10.1002 / 9780470672532$.

12. Gittings J. (2015). Philosophy and Peace. The Question of Peace in Modern Political Thought, ed. by T. Koivukoski \& D. E. Tabachnick. Waterloo: Wilfred Laurier University Press, pp. 31-55.

13. Gregory of Nyssa, st. (1863). O blazhenstvah. Slovo 7 [About bliss. Word 7]. Complete set of Works. Mosow: V. Gotie's typography. Pp. 12-28. (in Russian).

14. Gregory the Theologian, st. (1912). Chudiesnyie pesnopieniia. Slovo 4, o mirie [The mysterious chants. Word 4, about the Peace. Tvoreniya izhe vo svyatykh ottsa nashego Grigoriya Bogoslova, Arkhiepiskopa Konstantinopolskogo [The Works of Our Holy Father Gregory the Theologian, Archbishop of Constantinople]. vol. 1. Sankt-Peterburg: Petr Soykin Publ. Pp. 20-29. (in Russian).

15. Gregory the Theologian, st. (1912). Slovo 3 [Word 3]. Tvoreniya izhe vo svyatykh ottsa nashego Grigoriya Bogoslova, Arkhiepiskopa Konstantinopolskogo [The Works of Our Holy Father Gregory the Theologian, Archbishop of Constantinople], vol. 1. Sankt-Peterburg: Petr Soykin Publ. Pp. 515-524. (in Russian).

16. Gregory the Theologian, st. (1912). Slovo 6, O mirie, skzannoie v prisutstvii ottza poslie priedydushchiego molchaniia po sluchaiu vossoiedinieniia monahov [Word 6, About the Peace, was said in the presence 
of the father after the previous silence, on the occasion of the reunion of monks]. Tvoreniya izhe vo svyatykh ottsa nashego Grigoriya Bogoslova, Arkhiepiskopa Konstantinopolskogo [The Works of Our Holy Father Gregory the Theologian, Archbishop of Constantinople]. vol. 1. Sankt-Peterburg: Petr Soykin Publ. Pp. 323-334. (in Russian).

17. Hamblet W. (2017). Harvesting the Human: Force and Persuasion in Human Societies. Concerned Philosophers for Peace Newsletter Online. Retrieved from: http://peacephilosophy.org/325/wendy-hamblet-harvestingthe-human-force-and-persuasion-in-human-societies (accessed 12 January 2020).

18. Harari Y. N. (2016). Homo Deus: A Brief History of Tomorrow. London: Harvill Secker.

19. Harris I. (2006). Peace Studies between the Two Infinities. Newsletters of the Concerned Philosophers for Peace, vol. 26 (2). Retrieved from: http://peacephilosophy.org/94/peace-studies-between-infinities-by-ian-harris (accessed 18 January 2020).

20. Ilyin I. A. (1995). O soprotivlenii zlu siloiu [About resistance to evil by force]. Collected Works in 10 vol. Vol. 5. Moscow: Russkaia kniga. p. 217. (in Russian).

21. Internet-portal Dyvys' [Look]. 2017, 26 Oct. (in Ukrainian). Retrieved from: https://dyvys.info/2017/10/26/najbilshoyu-tsinnistyu-dlya-ukrayintsivye-myr-najmenshoyu-povaga-do-inshyh-kultur/ (accessed 20 January 2020).

22. John Chrysostom, st. (1898). Sravnenie vlasti, bogatstva i preimushchestv tsarskikh $\mathrm{s}$ istinnym $\mathrm{i}$ khristianskim lyubomudriem monasheskoy zhizni [The Comparison of the King's Power, Wealth and Advantages with the True and Christian Philisophy of Monastic Life]. Polnoie sobranie tvoreniy svyatitielya Ioanna Zlatousta [Complete collection of the works of St. John Chrysostom]. Vol. 1, Book 1. Sankt-Petersburg: Sankt-Pet. Theological Academy. Pp. 120-131. (in Russian).

23. John Paul II (1991). Encyclical Centesimus annus. Ukrainian Catholic University: Institute of Religion and Society. (in Ukrainian). Retrieved from: http://irs.ucu.edu.ua/dzherela/sotsialni-entsikliki/ivan-pavlo-ii-centesimusannus-1991. (accessed 20 January 2020).

24. Kant I. (1993). Grounding for the Metaphysics of Morals. Trans. by J. W. Ellington, (3rd ed.). Indianoapolis: Hackett.

25. Kapto A. S. (1990). Filosofiya mira: istoki, tendentsii, perspektivyi [The Philosophy of Peace: Sources, Trends, Prospects]. Moscow: Politizdat. (in Russian).

26. Koshin V. (1990). Filosofiya mira v yadernyiy vek [The philosophy of peace in the nuclear age]. Voprosyi filosofii [The Questions of Philosophy], no. 5, pp. 39-54. (in Russian). 
27. Kostyrev A. (2013). Kommunikatsionnaya vlast: sotsialnyie seti kak instrumentyi noopolitiki [Communication power: social networks as tools of noopolitics]. Political design in the space of social communications, vol. 2, pp. 49-56. (in Russian).

28. Kostyrev A. G. (2013). Ukraina: bufer ili forum? Mezhtsivilizatsionnaya kommunikatsiya kak geopoliticheskaya funktsiya Ukrainyi [Ukraine: buffer or forum? Inter-civilization communication as a geopolitical function of Ukraine]. LAP Lambert Academic Pablishing.

29. Ksenofontov V. N. (2008). Mir kak sostoyanie obschestva [Peace as a state of society]. Moscow: Russian Academy of Public Administration. (in Russian).

30. Missiya Pravoslavnoi Tcerkvi v sovremennom mire [Orthodox Church's mission in the modern world]. (2016). VI Vsemirnyi Pravoslavnyi Sobor [VI World Orthodox Meeting], Shambezy, 26-28 Jan. 2016. (in Russian). Retrieved from: http://www.patriarchia.ru/db/print/4360988.html (accessed 18 January 2020).

31. Osnovy sotcialnoyi kontceptciyi Rus'koyi Pravoslavnoyi Tcerkvy [The Fundamentals of the Russian Orthodox Church's Social Concept] (2002). Kyiv: Information and Publishing Center of the Ukrainian Orthodox Church. (in Ukranian). Retrieved from http://www.patriarchia.ru/ua/db/text/ 1207692.html (accessed 16 January 2020).

32. Rynne T. J. (2008). Gandhi and Jesus: The Saving Power of Nonviolence. London: Orbis Books.

33. Sovmestnoe zayavlenie Papyi Rimskogo Frantsiska i Svyateyshego Patriarha Kirilla [Joint statement by Pope Francis and His Holiness Patriarch Cyril]. Habana, 13 Feb. 2016. (in Russian). Retrieved from: http://www.patriarchia.ru/db/text/4372074.html (accessed 22 January 2020).

34. Thomas Aquinas, st. (2010). O spravedlivosti, vopros 91. Summa teologiyi [About a Justice, question 58. Summa Theologiae]: in 12 vol. Ed. by S. I. Yeremeyev. Kyiv: Nika-Centre, vol. VI. (in Russian). Retrieved from: https://azbyka.ru/otechnik/konfessii/summa-teologii-tom-6/ (accessed 19 January 2020).

35. Traer R. (2009). Christian Support for Human Rights. Religion and Human Rights. Retrieved from: http://religionhumanrights.com/Religion/ Christian/christian.fhr.htm (accessed 14 January 2020).

36. Tuck R. (1999). The Right of War and Peace: Political Thought and the International Order from Grotius to Kant. New York: Oxford University Press.

37. What is Peacebuilding? (2018). Alliance for Peacebuilding. Retrieved from: https://allianceforpeacebuilding.org/what-is-peacebuilding/ (accessed 10 January 2020). 
38. Yurkevich P. D. (1860). Mir s blizhnim kak usloviye khristianskogo obshchyezhytiya (Trudy Kyivskoy Duhovnoy Academiyi) [Peace with the neighbor as a condition of a Christian cohabitation (The Works of the Kyiv Theological Academy)]. Philosophskiye proizvyedyeniya [The Philosophical Works]. Moscow: Znaniye, 1990. (in Russian).

39. Yurkevich P. D. (1990). Serdtze I yego znacheniye n duhovnoy zhyzni chelovyeka, po ucheniyu Slova Bozhiya. Philosophskiye proizvyedyeniya. (A heart and its meaning in the spiritual life of man, according to the teaching of the Word of God. Philosophical works. Moscow: Znaniye, pp. 226-227. (in Russian).

40.Zvernennya Vseukrayinskoyi Rady Cerkov i Religijnykh Organizacii shhodo Stanovlennya Spravedlyvosti v Ukrayini [The Statement of the All-Ukrainian Council of Churches and Religious Organizations on the establishment of justice in Ukraine]. Kyiv, 17 May 2016. (in Ukrainian). Retrieved from: http://vrciro.org.ua/ua/statements/465-uccrostatement-justicecourt-judge-ukraine (accessed 16 January 2020).

41.Zvernennia Vseukrainskoi Rady Tserkov i Relihiinykh Orhanizatsii shchodo Utverdzhennia Myru Ta Postupu Ukrainskoho Suspilstva [The AllUkrainian Council of Churches and Religious Organizations Appeal on Promoting Peace and the Progress of Ukrainian Society]. Kramatorsk, 02 Nov. 2016. (in Ukrainian). Retrieved from: http://vrciro.org.ua/ua/ statements/475-uccrostatement-on-peace-in-ukraine (accessed 22 January 2020).

\section{Information about the author: Nikolay Nesprava,} $\mathrm{PhD}$ in Philosophical Sciences, Docent, Associate Professor at the Department of Social and Humanitarian Disciplines, Dnipropetrovsk State University of Internal Affairs 26, Prospect Gagarina, Dnipro, 49000, Ukraine ORCID ID: http://orcid.org/0000-0003-0415-1837 


\section{MODERN ASPECTS OF EU REGIONAL DEVELOPMENT POLICY}

\section{Mykola Palinchak}

\section{INTRODUCTION}

EU regional policy has been characterized by a history describing a period of over 50 years. Its essential filling has been transformed within this period. Initially, it was shaped around the implementation of infrastructure projects, and later became deeply meaningful in the form of the "Europe of the Regions" concept, which is the result of regional interactions deepening and complicating relations in the global competitive environment. Nowadays the importance of the "Europe of the Regions" is growing in the context of EU regional policy relative to subnational entities and in the geopolitical dimension as a whole.

In scientific literature much attention has been focused on the region as a structural unit of the integration union. It is often seen as a link between national member states with the EU as a coherent supranational entity. There are many representatives of foreign scientific environment and scientistseconomists from Ukraine among well-known researchers, studying the EU regions and the policies of the countries of regional character, e.g. EU regional policy has been considered by Y. Wannop, Z. Gerasymchuk, M. Dolishniy, M. McGinnis, D. Palma, M. Porter, G. Richardson, M. Storper, R. Walker, S. Hardy, M. Hart, V. Chuzhikov and others. However, as globalization and integration processes are becoming stronger in the global economic environment, new aspects of regional development and interaction are constantly emerging. The European Union is forced to monitor the necessary changes in regional policy constantly in order to be able to respond effectively to the challenges of the global economic environment and to be a fully-fledged strong player.

\section{Transformation of Regional Policy in the EU}

There are various interpretations of the concept "region" in scientific literature, particularly in regional studies, and namely:

1. The part of the country (region, district) that differs from the others in certain ways: natural-climatic, economic-geographical and others, which are considered in combination with the peculiarities of the national composition of the population.

2. Spatially organized form of population life activity, including the spheres of residence, professional and labor activity, managed from a single 
center and united by numerous links (industrial, political, socio-economic, cultural, ethnic, etc.) on the basis of self-management and full realization of their rights as a subject of socio-political life.

3. A large taxonomic unit of the production-territorial structure of the country and a form of organization of production and social life of the population, which is characterized by geoeconomic, geopolitical, productioneconomic, cultural-ethnic, dynamic characteristics.

4. Territory within the administrative boundaries of a particular country, characterized by the complexity, integrity, specialization and controllability, that is, the presence of political and administrative governing bodies ${ }^{1}$.

On the basis of such approaches, the characteristic features of the region have been distinguished. The most important of them are:

- the unity and integrity of the region;

- community and unity of the economy;

- comprehensive economy;

- availability of population possessing appropriate education, qualification and traditional production skills;

- entering the market and using the actual amount of labor, land, capital;

- specialization;

- controllability that implies the functioning of political and administrative governing bodies ${ }^{2}$.

Most often the "region" is considered within the national boundaries, although the variety of ways of its interpreting goes beyond the state level. That is, the region may be a state as a whole, and several states being close in character, criteria of analysis or practice.

The concept of regional policy is a complex and multidimensional concept. The regional policy of the European Union (further - EU), also referred as Cohesion Policy, is a policy with the stated aim of improving the economic well-being of regions in the EU and also to avoid regional disparities ${ }^{3}$.

It is a policy aimed at managing economic, political and social development within the region in order to achieve the set goals complemented simultaneously with the crystallization process along with the dynamic changes of the EU development as a separate integration group within the

${ }^{1}$ Бутов В.И., Игнатов В.Г., Кетова Н.П. Основы региональной экономикию. Москва, Ростов-на-Дону : Мар, 2000. 448 с.

${ }^{2}$ Регіональна політика Європейського Союзу : підручник / за ред. В. Чужикова. Київ : KHEУ, 2016. 495 c.

${ }^{3}$ Regional policy of the European Union. URL: https://en.wikipedia.org/wiki/Regional_ policy_of_the_European_Union 
world economy. The achievement of the goals is partly due to the interaction of the regions with each other.

O. Polikarpova analyzed the transformation of the EU Regional Policy objectives within the period from 2000 to 2020 (see Table 1).

Table 1

Transformation of EU regional policy objectives in 2000-2020 4

\begin{tabular}{|l|l|l|}
\hline \multicolumn{1}{|c|}{ 2000-2006 } & \multicolumn{1}{|c|}{$\mathbf{2 0 0 7 - 2 0 1 3}$} & \multicolumn{1}{c|}{$\mathbf{2 0 1 4 - 2 0 2 0}$} \\
\hline $\begin{array}{l}\text { Promoting of } \\
\text { development and } \\
\text { structural regulation of } \\
\text { lagging regions }\end{array}$ & $\begin{array}{l}\text { Convergence and } \\
\text { competitiveness }\end{array}$ & $\begin{array}{l}\text { Increasing economic } \\
\text { growth and investment, } \\
\text { poverty reduction }\end{array}$ \\
\hline $\begin{array}{l}\text { Supporting the } \\
\text { economic and social } \\
\text { transformation of areas } \\
\text { facing structural } \\
\text { difficulties }\end{array}$ & $\begin{array}{l}\text { Regional } \\
\text { competitiveness and } \\
\text { employment at } \\
\text { regional and national } \\
\text { level }\end{array}$ & $\begin{array}{l}\text { Research and } \\
\text { innovation, development } \\
\text { of information and } \\
\text { communication } \\
\text { technologies }\end{array}$ \\
\hline $\begin{array}{l}\text { Support of adaptation } \\
\text { and modernization } \\
\text { policies, training and } \\
\text { employment }\end{array}$ & $\begin{array}{l}\text { European territorial } \\
\text { cooperation }\end{array}$ & $\begin{array}{l}\text { Resources and } \\
\text { environment protection, } \\
\text { as well as strengthening } \\
\text { institutional capacity }\end{array}$ \\
\hline
\end{tabular}

Table 1 demonstrates that for three periods the main long-term goal is a policy of disparities balancing in the development of EU regions, along with the quality of domestic economic development improving in the first period, consolidation processes - in the second, and enhancing the EU's potential as a subject of international economic relations - in the third period.

The focus of the European Union on regional development has been also changed. Transformation of regional development policy is shown on Figure 1 .

Regional policy is an EU tool for local investment. It is directed to boost the economic growth and jobs and improve the life quality. Thanks to this active form of EU solidarity, people in less developed regions can seize the opportunities raised by the largest market in the world.

EU regional policy works to make a difference in five key areas:

- investing in people by supporting access to employment, education and social inclusion opportunities;

${ }^{4}$ Полікарпова О. Регіональна політика ЄС: практичний досвід для України. Вісник THEУ. 2015. № 3. C. 101-110. 
- supporting the development of small and medium size businesses;

- strengthening research and innovation through investment and researchrelated jobs;

- improving the environment through major investment projects;

- modernising transport and energy production to fight against climate change, with a focus on renewable energy and innovative transport infrastructure ${ }^{5}$.

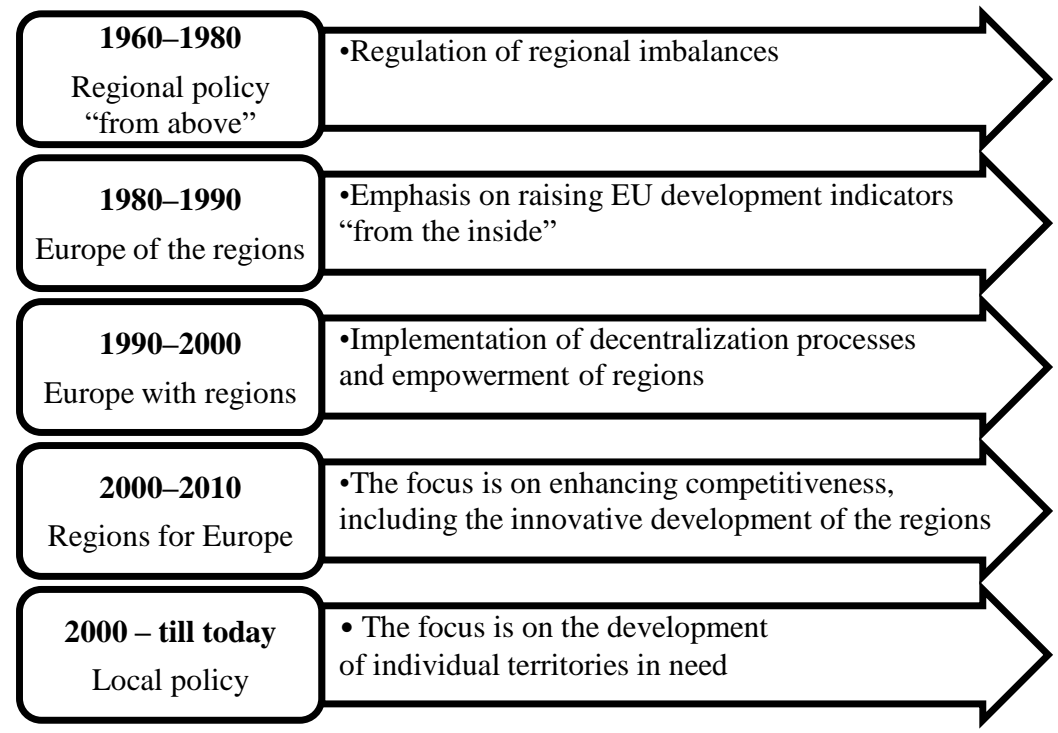

Fig. 1. Transformation of regional policy in the EU since $1960^{6}$

Regional policy is not just an economic policy, it covers, as mentioned above, social issues, namely employment, education and skills, which is particularly important. The development of small and medium-sized enterprises, innovative issues and supporting of various types of research are of great importance. These issues are complemented by environmental protection issues that at first glance appear to be separated from regional development. It is gratifying that the European Union is building its policy in

\footnotetext{
5 Regional policy. Regional investment and solidarity. URL: Regional Policy https://europa.eu/european-union/topics/regional-policy_en

${ }^{6}$ Innovative strategies of territorial development of V4: Experience for Ukraine / Y. Savelyev, I. Lishchynskyy, M. Lyzun, K. Borsekova, M. Sokołowicz, K. Vitališova, Y. Kurylyak. Ternopil: Terno-graf, 2016. 216 p.
} 
an integrated way, taking into account the fundamental aspects of sustainable development policy.

More than one third of the EU's budget is devoted to this policy, which aims to remove economic, social and territorial disparities across the EU, restructure declining industrial areas and diversify rural areas which have declining agriculture. In doing so, EU regional policy is geared towards making regions more competitive, fostering economic growth and creating new jobs ${ }^{7}$.

It is important to realize that the latest EU enlargement has resulted in a $10 \%$ increase in production, a $22 \%$ increase in population, $5 \%$ - in agriculture and $30 \%$ - in the number of unemployed. The population of regions with GDP per capita less than a third of the EU average has risen to 62 million $(20 \% \text { of the EU population })^{8}$. Such indicators further actualize the alignment of intra-regional EU asymmetries. In general, disproportionality is reflected in the indicators of living standards and economic development, which have only deepened with each phase of expansion ${ }^{8}$. On the one hand, the EU has expanded its potential and scope in the world economy, while on the other it was complemented by some economically backward regions and countries where domestic conflicts took place. Regions with varying duration of economic policy making and formation, specialization specificities, ethnic differences, which often result in civilizational clashes or interpenetrations, have begun to be clearly observed.

Currently, according to GDP per capita indicator (calculated on the PPP), EU countries are quantitatively divided into the following groups:

1. 10 relatively affluent countries in Western and Northern Europe (which include Ireland) with GDP per capita of more than $110 \%$ of the EU average;

2. Italy and Germany, where the GDP per capita is higher than the European average, in highly developed regions and "problem areas" (respectively in the south and east);

3. 7 small and medium-sized Mediterranean countries (including Spain and Slovenia) where GDP per capita is below the European average, but the gap does not exceed 30\%;

4. 9 Eastern European countries where GDP per capita has fluctuated from 30 to $70 \%$ of the EU average in recent years.

\footnotetext{
${ }^{7}$ Regional policy of the European Union. URL: https://en.wikipedia.org/wiki/Regional_ policy_of_the_European_Union

${ }^{8}$ Поліщук Л.С. Регіональні симетрії в СС та нові інструменти політики вирівнювання. Актуальні проблеми міжнародних відносин. 2015. Вип. 126 (част II). С. 116-124.
} 


\section{Structural Funds as Mechanisms of Regional Policy Implementation}

Asymmetry overcoming in the EU requires the costs of the Structural Funds and the development of equalization mechanisms ${ }^{8}$.

Within the period from 2014 to 2020 the European regional policy has been closely connected with the activity of three funds: the European Regional Development Fund (ERDF), The European Social Fund (ESF) and the Cohesion Fund (CF). Their activities are often compared or viewed within the context of other funds, such as the European Agricultural Fund for Rural Development (EAFRD), the European Maritime and Fisheries Fund (EMFF) and the Youth Employment Initiative (YEI). The percentage of allocation of these funds' financing processes within the period from 2014 to 2020 is shown at Figure 2.

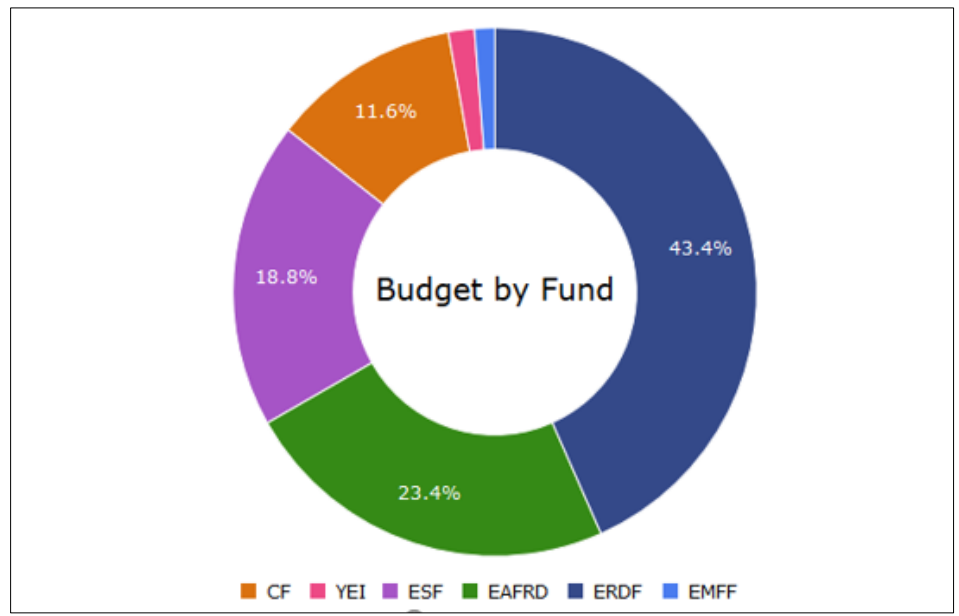

Fig. 2. Allocation of funds of EU Structural Funds for the period 2014-2020, $\%^{9}$

The largest amounts of funding are provided by the European Regional Development Fund. The European Agricultural Fund for Rural Development ranks second in terms of funds. They are immediately followed by the European Social Fund and the Cohesion Fund. Together, these 4 funds account for $97.2 \%$ of the funds. In fact, they are the main financial instruments for implementing EU regional development policy.

9 European Structural and Investment Funds. EU Overview. URL: https://cohesiondata.ec.europa.eu/overview\# 
It is important to examine in greater detail the competence of each fund in the field of regional policy implementation.

The aim of the European Regional Development Fund's activity is to reduce the economic and social imbalances between the EU regions. The central part is occupied by the attention to research and innovation, small and medium entrepreneurship, digital and the low-carbon economy. Combined approach of the European Regional Development Fund to financing these spheres in different types of regions is worth our attention. So, the amount of resources allocated by the ERDF depends on the level of the region development. The ERDF resources allocated to these priorities will depend on the category of region. At least $80 \%$ of funds must focus on at least two of these priorities in more developed regions. In transition regions, this index is $60 \%$ of the funds and $50 \%$ - in less developed regions.

A differentiated approach is also maintained for financing low-carbon economy projects. $20 \%$ of the allocated funds are sent to the developed regions, $15 \%$ - to the transition regions and $12 \%$ - to the less developed ones $^{10}$. It is gratifying to note that a feature of EU regional policy is that the least developed regions, although less involved in the priority areas of the EU economy, are not deprived of them.

One of the important goals of the European Regional Development Fund is to reduce the importance of borders within Europe. Reducing the importance of borders is important both between and within EU countries. The ERDF can achieve this goal by activating regional cooperation, and namely: cross-border, transnational and interregional cooperation. This trend can be developed in the form of cross-border and transnational as well as interregional cooperation.

The European Social Fund is busy with the poverty problem and its solution. Much attention has been devoted to the education issue. This fund is oriented to help people who are in the risk group according to the poverty as a result of education, training and employment issues increasing ${ }^{11}$.

During the specified period from 2014 to 2020 the activities of the European Regional Development Fund and the European Social Fund are oriented differently to different regions of the European Union. At figure 3 the eligibility of the funds is marked by the color.

${ }^{10}$ European Regional Development Fund. The ERDF aims to strengthen economic and social cohesion in the European Union by correcting imbalances between its regions. URL: https://ec.europa.eu/regional_policy/en/funding/erdf/

${ }^{11}$ A Europe of the regions - What is EU Regional Policy? URL: http://hum.port.ac.uk/ europeanstudieshub/learning/module-3-governance-in-a-multi-level-europe/a-europe-of-theregions-what-is-eu-regional-policy/ 

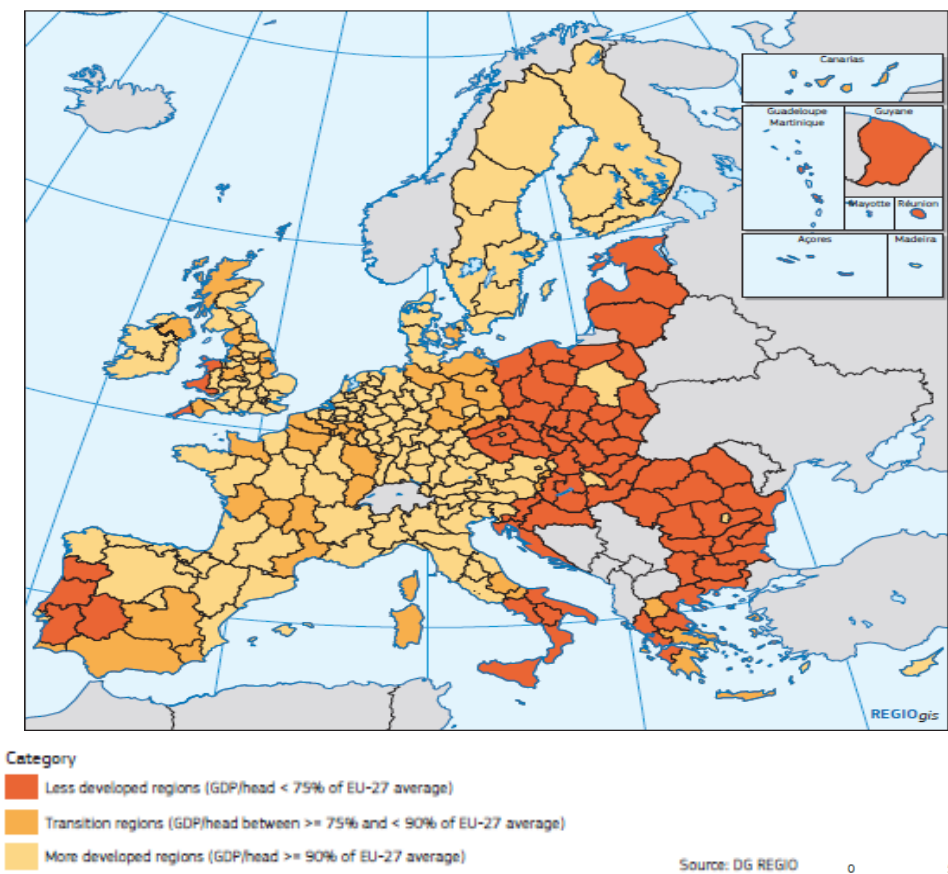

\section{Fig. 3. The eligibility of the Structural Funds (ERDF and ESF) within the period from 2014 to $2020^{12}$}

Figure 3 shows that most of these funds are directed to the least developed regions where GDP per capita is less than the EU-27 and transitional economies, where GDP per capita is more than $75 \%$ and less than $90 \%$ of the EU - 27 average. It is important to note that, to a lesser extent, attention is also paid to developed regions where GDP per capita is more than $90 \%$ of the EU -27 average. That is, Structural Funds contribute to both narrowing the gap between levels of regional development and maintaining high levels of development. In general, it influences the unity and mutual understanding of the regions and the strength of such an integration structure and its position in the market. This completely dispels the myth that only the least developed countries benefit from the structural funds' financing of the regional development, while the largest financial contributions are made by the

${ }^{12}$ My Region, my Europe, our Future. Seventh report on economic, social and territorial cohesion / L. Dijkstra, European Commission, Directorate-General for Regional and Urban Policy. Luxembourg : Publications Office of the European Union, 2017. 220 p. 
developed countries. In 2017, 11 EU countries - the richest - paid more into the EU budget than what they received back in EU funding ${ }^{13}$.

Even if these countries do not receive so much direct financial benefits, they can enjoy the opportunities created in this way throughout the European Union, namely they live in a stable economic and political environment within the EU with the appropriate level of security. The implementation of infrastructure projects also creates the appropriate conditions from which developed regions benefit and can focus on integration freedoms ensuring. This myth is also debunked by international trade, whose growth confirms the involvement of both the underdeveloped and developed EU regions.

The aim of the Cohesion Fund activity is to help the regions whose GNI/inhabitant is less than $90 \%$ of the EU average to approach towards the richer regions. Regions of this kind are: Bulgaria, Croatia, Cyprus, the Czech Republic, Estonia, Greece, Hungary, Latvia, Lithuania, Malta, Poland, Portugal, Romania, Slovakia and Slovenia.

Financial resources of the Cohesion Fund $(€ 63.4$ billion for the 2014-2020 period) are allocated to specific areas. One of the priorities is the direction of trans-European transport networks. The European Union pays much attention to infrastructure projects in the framework of the cooperation with the Connecting Europe Facility, whose main objective is a high level of connectivity between European Union member states. Much attention is paid by the European Union to the environment and ecological issues, which are also part of the Cohesion Fund's competence. The Cohesion Fund supports projects related to energy or transport, developing rail transport, supporting intermodality, strengthening public transport etc. ${ }^{14}$

Generally, it can be noted that the investment priorities of the Cohesion Fund are all measures that contribute to the development of:

- a low-carbon economy;

- climate change adaptation, risk prevention and management;

- environmental protection/conservation;

- sustainable transport and removing bottlenecks ${ }^{15}$.

The European Regional Development Fund and the Cohesion Fund mainly implement the largest projects in the field of EU regional policy. 'Major Projects' are usually large-scale infrastructure projects in transport,

1310 myths and facts about EU Cohesion policy URL: https://ec.europa.eu/regional_ policy/en/policy/what/myth-busting/

${ }^{14}$ Cohesion Fund. URL: https://ec.europa.eu/regional_policy/en/funding/cohesion-fund/

15 Cohesion Fund (2014-20) URL: https://eur-lex.europa.eu/legal-content/EN/TXT/?uri= legissum:2602_2 
environment and other sectors such as culture, education, energy or $\mathrm{ICT}^{16}$. More than $€ 50$ million is being allocated for their implementation. It is important to consider the degree of the largest projects implementation by EU regions (see Figure 4).

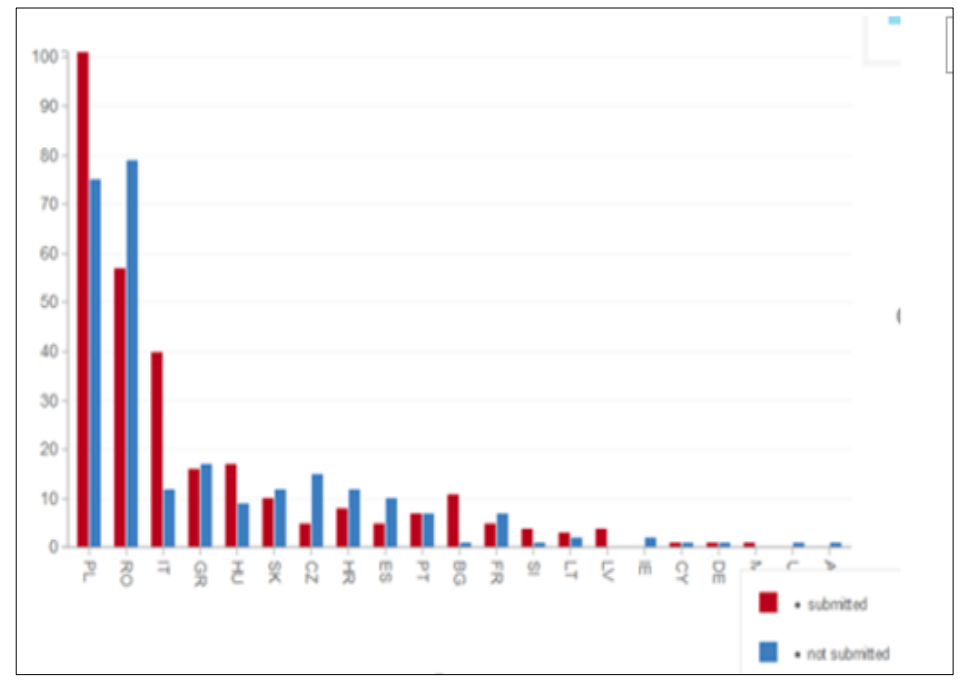

Fig. 4. Participation of countries in the implementation of EU regional development projects ${ }^{16}$

Figure 4 shows that countries are involved differently in various regional policy development projects. Poland, Romania and Italy are most involved in this process. In Poland and Italy, the implemented projects prevail, in Romania - those that have not been completed. Participation of other countries is less active and there is no clear trend for project implementation or non-implementation. It depends on various factors inherent in countries.

The total budget of the EU Structural Funds (European Regional Development Fund, Cohesion Fund, European Social Fund) for the period from 2014 to 2020 is $\$ 314.88$ billion $^{17}$. The budget is aimed at strengthening the link between cohesion policy and other common policies of the European Union, as well as developing smart strategies, job creation, tackling climate change and energy dependency, poverty reduction and social exclusion.

\footnotetext{
${ }^{16}$ Major projects. URL: https://ec.europa.eu/regional_policy/en/projects/major/

${ }^{17}$ Полікарпова О. Регіональна політика ЄС: практичний досвід для України. Вісник THEУ. 2015. № 3. C. 101-110.
} 
It is important to note that the process of regionalization is closely connected with the governance processes in the European Union. It should be clearly understood that regionalism is a reflection of the decentralization process, which entails the transfer of powers to regional authorities and is based on the principle of subsidiarity ${ }^{18}$. The cohesion policy 2014-2020 is aimed at creating strategic and institutional capacity, democratic legitimacy, strengthening administrative capacity. $67.2 \%$ of the total budget is allocated to this ${ }^{17}$.

The EU regional policy is not isolated but organically integrated into the overall economic policy of the integration group. Therefore, the threats affecting the EU economy as a whole undoubtedly transform the EU's regional policy. It should be noted that a comprehensive study of EU threats to be monitored has received little attention in scientific literature. The importance of permanent monitoring of the level of regional development is increasing in the context of transformational processes concerning regional development policy and the manifestation of economic crisis processes, which are much easier spread around the world as a result of globalization. A permanent monitoring approach would allow to systematize and develop preventative measures for the future. The current threats that already exist and the need of immediate resolution are identified most often.

Systematizing key threats and challenges of the EU functioning, L. Dorosh and O. Ivasechko distinguish their internal and external nature, while not forgetting their interdependence. Predominantly internal problems include the institutional crisis (the Brexit problem and making of a future vision for the EU's development) and the economic challenges that are partly influenced by the external factors. Key external threats include increased security challenges in the light of the latest hybrid conflicts in the region, the rise to power of D. Trump in the United States, terrorism as a way of destabilizing the internal situation in EU member states. Among the factors that undermine internal stability in the EU is, of course, the issue of the migration crisis. These factors indirectly affect the migration situation and politics, but are more concerned with social policy and the financial aspects of its implementation. Challenges of 2017-2018 include the possibility of launching a domino effect and increasing the tendency to withdraw from the Union of other states, the inability of its Member States to pursue a coordinated common domestic and foreign policy ${ }^{19}$.

${ }^{18}$ European Commission. Regional policy Inforegio website: EU cohesion funding - key statistics, Available budget 2014-2020. URL: http://ec.europa.eu/regional_policy/thefunds/ funding/index_en.cfm

19 Дорош Л., Івасечко О. Особливості функціонування та виклики розвитку СС у близькій перспективі (2017-2018 рр.). Політичні науки. 2017. № 3. С. 19-24. 
Overcoming current threats, the institutional structures of the European Union are carrying out planned regional development projects, but are not able to pay more attention to regional aspects of the Union's economic policies. In other words, the challenges of modern EU development are hampering the effective development of EU regional policy. Without the current challenges and threats, it could be argued that European regional development policy would have developed at a much faster pace.

It is advantageous and worth considering to re-establish positive experience by developing priority directions for regional policy prospects for the next seven-year period 2021-2027. Such priority areas of development are being developed taking into account the strategic goals and the challenges of today.

One of the areas of investment of the European Regional Development Fund and the European Cohesion Fund will remain the sphere of innovation. The process of digitization of the EU economy, the development of industrial technologies, entrepreneurship, especially small business will continue too. Emphasis will be placed on education and the employment of youth, migration issues, climate change control and the development of a low carbon economy. Cohesion support policies will continue to be maintained for all EU regions, and further efforts will be made to reduce disparities and promote low-income and low-growth catching-up regions. A feature of the 7-year future policy is to simplify procedures for re-orienting funds to more urgent issues in the case of need and to simplify the administration of EU spending as a whole ${ }^{20}$. The anticipated result of this approach is to make the European Union smarter, greener, carbon free, social more connected and closer to citizens $^{21}$.

In the context of integration aspirations realization, Ukraine has been building its relations with the European Union for a long time. These relationships are multidimensional and are often characterized by activation or on the contrary by retardment. These are not just economic or in particular integration issues, and they have often geopolitical character.

The EU-Ukraine Association Agreement has become an instrument for bringing Ukraine and the EU closer. This Agreement is an opportunity for cooperation in the regional aspect, an opportunity for united confrontation to global challenges that are equally confronting both Ukraine and the EU.

As a result of signing the Association Agreement, it can be stated with confidence that regional cooperation between Ukraine and the EU is not

${ }^{20}$ Куйбіда В. С., Федулова Л. І. Нова регіональна політика ЄС: уроки для України : аналіт.зап. Київ : НАДУ, 2019. 24 с.

${ }^{21}$ New Cohesion policy URL: https://ec.europa.eu/regional_policy/en/2021_2027/ 
limited to the state level, but develops at the level of individual administrative-territorial units. It has been stated in the Article 446 of the Association Agreement that "the Parties shall promote mutual understanding and bilateral cooperation in the field of regional policy concerning the methods of formulation and implementation of regional policies, in particular multilevel governance and partnership, with particular emphasis on the development of backward territories and territorial co-operation, while creating communication channels and enhancing the exchange of information between national, regional and local authorities, socio-economic entities and civil society representatives" 22 .

The deepening of cooperation between Ukraine and the EU in the regional aspect implies active cooperation of regional and local authorities. This requires the development of a clear legislative framework that will assist Ukraine's European integration steps in the future, as well as deepening crossborder and border links between regional units, often in the form of joint programs and projects, meetings and exchanges of experience. The regional level has multidimensional directions for the development of integration processes. Such areas as transport, energy, communications networks, culture, education, tourism, health care and the coordination of emergency services are particularly effective in this regard ${ }^{23}$.

In general, the European Union's experience in the field of regional policy points to the importance of certain aspects ${ }^{24}$, in particular:

1. High importance of economic framework conditions. The success of economic development depends on ensuring of equal conditions for economic actors of different levels. Within the framework of regional policy, it is advantageous to combine the cooperation of entities at the micro and macro levels within the framework of joint implementation of the general economic strategy.

2. Strategies and programs should be adapted to the current state of affairs. Prospective programs and strategies should be tailored to the needs and current challenges of the regional level. Otherwise they are doomed not to be successful.

3. The importance of the stable budgets and consistent programming. The advantage of the European Union is the development of a seven-year

22 Угода про Асоціацію між Україною, з однієї сторони, та Європейським Союзом, Свропейським співтовариством з атомної енергії і їхніми державами-членами, 3 іншої сторони. URL: http://zakon3.rada.gov.ua/laws/show/984_011

23 Куриляк М.Ю. Еволюція концепції “Свропи регіонів” у рамках регіональної політики ЄС. Економічний вісник Донбасу. 2018. № 2 (52). С. 60-67.

24 Європейська регіональна політика: натхнення для країн, що не входять до ЄС? Застосування принципів та обмін досвідом. URL: https://ec.europa.eu>international>external_uk 
budgetary strategy that allows the planning and implementation of long-term investment into regional development and policy. This approach allows a more careful planning and adjustment of expenditures in program implementation and budget expenditures.

4. The need for international cooperation. EU experience shows that the implementation and promotion of cross-border, transnational and interregional cooperation, which are important elements of regional policy, contribute to the development of constructive interaction between regions within and outside the neighboring countries. This in turn gives benefits not only in the economic and political spheres, but also in the social, cultural, spiritual and others.

5. Economics of agglomerations and urbanization. It is also an important component of European regional development policy. Although the region of Europe is a central focus of economic policy, particular attention is paid to the development of large cities as centers of innovative development and key drivers of economic growth.

6. The role of small and medium-sized cities and local centers. In the context of regional policy, the EU pays much attention to the polycentric development, where identical attention is given to small and medium-sized cities alongside to large cities. They provide connectivity with major cities and the dissemination of economic developments that have passed their lifecycle in major cities and continue them in downtowns with lower levels of urbanization. The EU is spending a lot of effort to develop rural areas and prevent significant depopulation processes, understanding all the threats that may be posed.

7. Local employment and capacity building initiatives. First and foremost such initiatives are connected with the development of the backward regions where the poverty issue is particularly actual. Overcoming the imbalances of regional territorial development implies an increase in the level of employment and, accordingly, the well-being of citizens living in these regions, and in general the level of their economic development, which lays the foundation for their future development, taking into account the challenges of today.

8. Strong institutional support. In order to achieve the successful implementation of regional initiatives, the institutional mechanism should function coherently and be well coordinated. The institutional mechanism includes both the institutions directly or indirectly involved in the implementation of EU regional policy, and the links between them, the activities of which are aimed at achieving the set of goals of regional development and securing the interests of actors of different levels and fields of activity. 
9. Multilevel management. This type of management includes vertical and horizontal elements that activate integration processes.

Within the vertical management system, various levels of European, national, regional and local governments are being promoted through a plan and program development system that has developed over the years to provide information sharing and one-way traffic for local benefits. Within the horizontal management system of the company, social groups and civic organizations are actively involved in the process and activities of governing bodies $^{24}$.

\section{CONCLUSIONS}

The EU's regional policy has undergone significant transformations during its existence, evolving from a policy of a united Europe to create a favorable economic environment to a policy of united potential of a strong player in the international arena. The strategic goals of EU regional policy were to ensure the economic growth of the community as a single integration group and a correspondingly high level of citizens' well-being. The overarching goals remained unchanged, while the interim goals that ensured the implementation of the chosen strategy were adjusted according to the current situation and the global economic environment. The European Union is making continuous efforts to minimize the disproportionate and asymmetric development of EU regions, facilitating the management and regulation of individual processes. The main tools are the EU Structural Funds financial mechanisms that implement regional development programs differing in several levels of development. It is important to take into account the inconsistency of individual myths about the inefficiency of regional policy and the overriding focus on underdeveloped regions. Indirect benefits also come from developed regions, which are more involved in the financing and implementation of EU regional policy. Certain regional policy approaches may be exemplary for countries, including Ukraine, for the interaction of regions in order to strengthen the integrity and economic potential of the subject of international relations.

\section{SUMMARY}

The main aspects of the EU regional policy transformation have been considered by the author. The essence and main characteristics of the region have been analyzed. Today the region is of great importance in the global economic environment, so much attention has been paid to regional policy. The transformation of the goals of EU regional policy during 2000-2020 has been analyzed by the author. The Structural Funds are the financial mechanism for the implementation of EU regional policy. They help to reduce 
imbalances in the levels of development of the regions, to support the high level of development of the rich ones, which affects the unity and cooperation of the regions. The EU regional policy is an integral part of the overall economic policy of the integration grouping and is influenced by the threats of the EU economy as a whole. The importance of permanent monitoring the level of regional development in the context of transformation processes and the manifestation of economic crisis phenomena in the era of globalization has been emphasized by the author. That will allow timely response to threats and preventive measures working-out. Some elements of the EU regional policy experience can be applied to regional development policy in Ukraine.

\section{REFERENCES}

1. Бутов В.И., Игнатов В.Г., Кетова Н.П. Основы региональной экономикию. Москва, Ростов-на-Дону : Мар, 2000. 448 с.

2. Регіональна політика Свропейського Союзу : підручник / за ред. В. Чужикова. Київ : КНЕУ, 2016. 495 с.

3. Regional policy of the European Union. URL: https://en.wikipedia.org/wiki/Regional_policy_of_the_European_Union

4. Полікарпова О. Регіональна політика $€ С$ : практичний досвід для України. Вісник ТНЕУ. 2015. № 3. С. 101-110.

5. Innovative strategies of territorial development of V4: Experience for Ukraine / Y. Savelyev, I. Lishchynskyy, M. Lyzun, K. Borsekova, M. Sokołowicz, K. Vitališova, Y. Kurylyak. Ternopil: Terno-graf, 2016. 216 p.

6. Regional policy. Regional investment and solidarity. URL: Regional Policy https://europa.eu/european-union/topics/regional-policy_en

7. Regional policy of the European Union. URL: https://en.wikipedia.org/ wiki/Regional_policy_of_the_European_Union

8. Поліщук Л.С. Регіональні симетрії в СС та нові інструменти політики вирівнювання. Актуальні проблеми міжнародних відносин. 2015. Вип. 126 (част II). С. 116-124.

9. European Structural and Investment Funds. EU Overview. URL: https://cohesiondata.ec.europa.eu/overview\#

10. European Regional Development Fund. The ERDF aims to strengthen economic and social cohesion in the European Union by correcting imbalances between its regions. URL: https://ec.europa.eu/regional_policy/ en/funding/erdf/

11. A Europe of the regions - What is EU Regional Policy? URL: http://hum.port.ac.uk/europeanstudieshub/learning/module-3-governance-in-amulti-level-europe/a-europe-of-the-regions-what-is-eu-regional-policy/

12. My Region, my Europe, our Future. Seventh report on economic, social and territorial cohesion / L. Dijkstra, European Commission, 
Directorate-General for Regional and Urban Policy. Luxembourg : Publications Office of the European Union, 2017. 220 p.

13.10 myths and facts about EU Cohesion policy URL: https://ec.europa.eu/regional_policy/en/policy/what/myth-busting/

14. Cohesion Fund. URL: https://ec.europa.eu/regional_policy/en/funding/ cohesion-fund/

15. Cohesion Fund (2014-2020) URL: https://eur-lex.europa.eu/legalcontent/EN/TXT/?uri=legissum:2602_2

16. Major projects. URL: https://ec.europa.eu/regional_policy/en/projects/ major/

17. Полікарпова О. Регіональна політика СС: практичний досвід для України. Вісник ТНЕУ. 2015. № 3. С. 101-110.

18. European Commission. Regional policy Inforegio website: EU cohesion funding - key statistics, Available budget 2014-2020. URL: http://ec.europa.eu/regional_policy/thefunds/funding/index_en.cfm

19. Дорош Л., Івасечко О. Особливості функціонування та виклики розвитку ЄС у близькій перспективі (2017-2018 рр.). Політичні науки. 2017. № 3. C. 19-24.

20. Куйбіда В. С., Федулова Л. І. Нова регіональна політика СС: уроки для України : аналіт.зап. Київ : НАДУ, 2019. 24 с.

21. New Cohesion policy URL: https://ec.europa.eu/regional_policy/en/ 2021_2027/

22. Угода про Асоціацію між Україною, 3 однієї сторони, та Європейським Союзом, Європейським співтовариством з атомної енергії i їхніми державами-членами, 3 іншої сторони. URL: http://zakon3.rada.gov.ua/laws/show/984_011

23. Куриляк М.Ю. Еволюція концепції “Свропи регіонів” у рамках регіональної політики ЄС. Економічний вісник Донбасу. 2018. № 2 (52). C. $60-67$.

24. Свропейська регіональна політика: натхнення для країн, що не входять до ЄC? Застосування принципів та обмін досвідом. URL: https://ec.europa.eu>international>external_uk

Information about the author: Mykola Palinchak, Doctor of Political Science, Professor, State higher education institution "Uzhhorod National University" 14, Universytetska str., Uzhhorod, 88000, Ukraine

ORCID: orcid.org/0000-0002-9990-5314 


\section{SPIRITUAL DIMENSIONS OF THE EDUCATIONAL PROCESS}

\section{Nadiia Skotna}

\section{INTRODUCTION}

There are several reasons behind our intent to address the problem of spiritual dimensions of the educational-pedagogical space. Firstly, we continue to reflect on the fate of man in the conditions of dramatic changes that are taking place in modern civilization ${ }^{1}$. It is a very different type of civilization, the peculiarity of which is instability, a great level of dynamism in different spheres of social life, which significantly complicates the process of a personality development. With the flow of information growing rapidly, it is difficult for a man to perceive polyphony of values, worldview concepts and actions. "The world is becoming very dangerous, and at the same time it is a world which has many opportunities"2.

But we are particularly concerned about the situation of the spiritual crisis in all the spheres of human life. We are witnessing separation of people when "living human impulses, sincerity, sensitivity, either dying, or turning into wild, vulgar, primitive passions, the living human soul becomes the environment of combinatorial computing activity"3.

Unfortunately, the society, having protection against such challenges of the present in the education system as a potential condition for cultivation of the truly human qualities in a person (reasonableness, religiosity and morality), its inclusion in culture, ignores such an opportunity. We are witnessing extraordinary enthusiasm for knowledge and education, but at the same time, only the body grows in education and science, "which consists of many pieces of information, while its very soul - a system of rational principles - remains without culture and without information about itself as well as own relation to itself and own attitude to the last goals of the human person"4. Many great scholars of the twentieth century are unanimous in that

\footnotetext{
${ }^{1}$ Скотна Н.В. Особа в розколотій цивілізації : освіта, світогляд, дії: монографія. Львів : Українські технологї, 2005. - 384 с.

${ }^{2}$ Черниговская Т. “Задача образования - научить сохранять человечность в цифровом мире” URL: https://philologist.livejournal.com/10596473.html]

3 Лимонченко В.В. Опыт философской аналитики антропологического дискурса в Православии : монографія. - Дрогобич : Видавничий відділ Дрогобицького державного педагогічного університету імені Івана Франка, 2014. - С. 8.

${ }^{4}$ Юркевич П. Д. Разум по учению Платона и опыт по учению Канта. / П. Юркевич // Философские произведения.. - М. : Правда, 1990. - С. 525.
} 
the University system is experiencing a period of "hypertrophy of means and atrophy of goals" (K. Jaspers, H.-G. Gadamer, J. Derrida, V. Lepeniz, etc.). The spiritual system is fundamentally removed from the modern education system. Undoubtedly, such tragic events as Chernobyl are terrible. But equally scary is "spiritual Chornobyl" (I. Arshavsky).

Secondly, we are concerned about ongoing reforms in the Ukrainian educational space and a focus on the Western values and ideals. Unfortunately, the spiritual experience of H. Skovoroda and V. Sukhomlinsky or representatives of the "pedagogy of cooperation" of the XX century (Sh.O. Amonoshvili, S.M Lysenkova, V.F. Shatalov, etc.) is neglected in favor of thoughtless copying of Western educational paradigms which become the basis for defining new standards and content of education. At the same time, the language stamps are repeated that "educational systems have a very serious national identity ..., there is a certain cultural context and there is our history...". We emphasize that the principles of Ukrainian education are somewhat different, more original and a purely pragmatic Western approach cannot be applied to them.

\section{Philosophical-religious principles of spiritual dimensions of the pedagogical process}

Reflections on the spiritual dimensions of educational activity highlight the philosophy of education as a special way of philosophical reflection, through which it is possible to identify new meanings in the formation and development of man in the modern civilization. Indeed, "in the functional dimension, spirituality emerges as the capacity and need for value vision, assimilation, and transformation of the world, as a means of going beyond the directly vivid existence, as an orientation to supra-personal values and meanings. Spirituality gives the human life in all its dimensions the connectedness and integrity, the defined, internally needed landmarks. Spirituality has an important existential and philosophical and categorical status as an integrative, systemic characteristic of a person, his or her life world, being in general"6. A representative of the Marburg School of NeoKantianism, the German philosopher Paul Nathorp, emphasized that pedagogy is nothing more than a concrete philosophy, which must constantly bring the creative force of its principles to the problems of human education.

\footnotetext{
${ }^{5}$ Гриневич Л. “Нова українська школа - це школа для життя у XXI столітті”

URL: https://hromadske.ua/posts/nova-ukrainska-shkola-tse-shkola-dlia-zhyttia-u-xxi-stolittiinterviu-z-ministrom-osvity-i-nauky-ukrainy

${ }^{6}$ Степаненко I. В. Духовність і душевність: категоріальні контури і функціональні можливості / І. В. Степаненко //Гуманітарний часопис - 2005. - № 1. - С. 12.
} 
We are aware that this brief overview which we offer in this section will be incomplete and fragmentary, but will nevertheless highlight the fundamental ideas and principles that are important to our study.

Greek culture plays a special role in understanding the spiritual dimensions of education and upbringing. The search for the fundamental ontological foundations of education sends us to the category of "paideia" as an organic component of ancient Greek society. Unfortunately, in the modern world paideia is often misunderstood as a universal form of learning, confirming trends in utilitarian understanding of educational tasks, methods, and functions. For modern pragmatic thinking, which has lost touch with the depth of many fundamental categories, such as "education", "upbringing", it is difficult to understand Socrates or Plato, for whom the comprehension of formative origins occurred in mental-spiritual dimensions. It was the Greeks who first introduced the system of principles of education - paideia - as a program of cultivation of the truly human features in man, introducing it into the culture, into the life of the Spirit. That program was based on the study of human nature, the awareness of the transcendent and at the same time immanent patterns that determine the physical and spiritual powers of man. There is a discovery of a person as self-sufficient value, the recognition of the right to be active and the laying on of a reasonable start. Topical are the ideas of Plato, for which education is the desire for wisdom, the help of the mind to become truly the highest Blessing (Truth, Beauty, Love) and the desire to fill human life and the world around with it.

G. Hegel paid considerable attention to the philosophical foundations of education. He was aware that the conditions for the existence of philosophy are contained in education, that is, the man's involvement in philosophy, contemplation - the ability to think. According to Hegel, a characteristic feature of man in general is that he is released from the direct and natural. "Taken in this aspect, it does not come naturally as it should be,"7 and therefore it needs education. Based on the concept of ascension to the universal, which encompasses the essential definition of the man's reason as a whole, Hegel was able to distinguish the essential in education - the general essence of consciousness is that a person makes himself in all respects a spiritual being. Thus, education as ascension to the universal is the man's main task.

According to S.Frank, spirituality is a fundamental, original characteristic of man. Everyone is eternally spiritual, but not everyone is aware of it, and not

${ }^{7}$ Гегель - Крейцеру (черновик), конец мая 1821 г. // Гегель Г. В. Ф. Работы разных лет. В 2-х т. - Т. 2. / Вильгельм Фридрих Гегель; [Сост., общ. ред. А. В. Гулыги]. - М. : Мысль, 1971. - C. 67. 
everyone consciously acts accordingly. However, only the spiritual beginning, according to the philosopher, makes a person involved in God, and only thanks to this is his true life possible: "Man feels the need for an unconditionally unwavering self-affirmative basis for his existence, and this basis is what we call God", The original idea of education in S. Frank's philosophy is important to us, which is that education is a patrimonial creative activity. In substantiating this idea, S.Frank proceeds from the fact that man does not create only external things, even if these are artistic, scientific, philosophical, theological works, not only the environment of his life, but, most importantly, man creates his own self. In other words, the subject of human creation is not only the culture in the broadest sense of the word, but also the "creation", "action" (G. Hegel) of the man himself. SL Frank says that "every kindergarten teacher is already a creator" .

I.Ilyin reveals the guidelines of spiritual education by substantiating methodological positions of understanding of the spiritual essence of the person, his soul, spiritual abilities. The philosopher emphasizes the need to find ways to unlock the spiritual faculties of man and proposes this way - to preserve the ability of heartfelt contemplation, heartfelt, spiritual love. This statement reveals an inseparable relationship between spirituality and spirituality. IO Ilyin notes: "A person who is spiritually defective since childhood can produce even a special mental image, which, when viewed superficially, can be mistaken for character and special ideas that are mistaken for "beliefs". In truth, being unprincipled and uncharacteristic, he always remains a slave to his own wicked passions, captivated by elaborate mental mechanisms that have accepted his and are omnipotent in his life, have no spiritual dimension and make a curve of his disgusting behavior. He does not resist them but disingenuously enjoys their game, forcing naive people to take their evil ability to adapt for "will", their instinctive cunning for "mind", their urge of evil passions for "feelings" 10 .

According to P. Yurkevich, religious experience reveals to us the fact that the heart is a deeper foundation of the spiritual life than the mind. The heart of a person can open and grasp, express and understand - in his own unique way - such experiences of the spirit, which by virtue of their exceptional spirituality and tenderness, distant knowledge of the mind are unattainable. The concept and distant knowledge of the mind, since it is formed by our

${ }^{8}$ Франк С. Л. Реальность и человек: метафизика человеческого бытия // Франк. С.Л. С нами Бог. М.: АСТ, 2003. - С. 286.

${ }^{9}$ Франк С. Л. Реальность и человек: метафизика человеческого бытия // Франк. С.Л. С нами Бог. М.: АСТ, 2003. - С. 347.

${ }^{10}$ Ильин И.А. О сопротивлении злу силою // Ильин И.А. Путь к очевидности. - М.: Республика, 1993. - С. 11. 
mental mood, and does not remain a distant image of external objects - is opened in the heart of man, not in the head. It must penetrate into this depth to become an active force in our spiritual life.

M. Heidegger emphasized that education and upbringing are the formation of oneself, the creation of one's own essence according to their own ontological nature. According to M. Heidegger, modern thinking is mainly instrumental in nature, since it serves primarily the field of natural sciences and technology. It is "calculative thinking", which in its own right is useful, but teaching such thinking does not lead to "humanization". In fact, modern man "flees" from thinking. Along with the development of science and technology, there is an indifference to reflections, a total thoughtlessness leading to people's beginning to deny and reject deep reflections on the sense that prevail in the world, and which, in fact, is its defining characteristic. This growing thoughtlessness is based on the process of deformation and destruction of the "inside of the modern man" subject of education from its human spiritual essence. As José Ortega y Gasset wrote in The Mission of the University, a modern specialist is a "new barbarian who has moved away from his era, archaic and primitive with respect to the horrific present and its problems. This new barbarian, in principle, is a professional who knows a lot more than ever before, but he is an engineer, a doctor, a lawyer, a scientist - and also much more cultured"12.

V.Movchan emphasizes the extra-moral orientation of modern educational technologies both in terms of the content of education and its purpose ${ }^{13}$. According to the Ukrainian scholar, a spiritual and moral component has been fundamentally removed from the European system of education; it gives only the knowledge needed to form a performer, a public servant and an employee. Having acquired certain skills, one becomes an intellectual craftsman. This problem is relevant for the Ukrainian system of education and upbringing of young people, which arose on the background of superficial interpretation of the values of Western civilization, the introduction of the idea of professionalism, competence as the most important and most important in the life and activity of man. As for spiritual and moral qualities, they are often ignored. As a result, the gap between professional training and moral status of

\footnotetext{
${ }^{11}$ Хайдеггер М. Отрешённость / М. Хайдеггер ; [пер. с нем. А.С.Солодовникова] // Хайдеггер М. Разговор на просёлочной дороге / М. Хайдеггер. - М. : Высшая школа, 1991. - C. 102.

${ }^{12}$ Ортега-и-Гассет X. Миссия университета URL: http://www.management.com.ua/vision/ vis009.html

13 Мовчан В.С. Глобалізація: до проблеми морального критерію процесу // Людинознавчі студії: Збірник наукових праць Дрогобицького державного педагогічного університету ім. І.Франка. - Дрогобич: Науково-видавничий центр ДДПУ ім. І.Франка, 2008. - C. 43-53.
} 
an individual is widening. In mass media, in special editions, most of the talk is about professional skills as the main criterion for the value of a specialist and personality whereas his spiritual essence remains unaddressed. Meanwhile, the juxtaposition of the scientifically rational and the moralspiritual is unnatural, because science and intelligence together with morality are the most important components of the spiritual world of the individual.

Reflecting on three types of pedagogy: pedagogy of formation; for pedagogy of abilities or development for the sake of development and pedagogy meaning upbringing or compassion, Batishev emphasizes that for those who associate their efforts and hopes with the system of updating educational - spiritual and civic - processes will require a third type of pedagogy. "Here, priority is given to that tier in the structure of the spiritual and spiritual world, which should be above all abilities, talents and forces, above the sphere of activity, namely - unconditional value commitment. Such a higher tier has the purpose of striving for the whole person, his whole lifedestiny, to agree with truth and beauty, goodness and community. It is the internal (conscientious) instance that directs and controls the abilities and their development. In this tier, a person finds that very co-creative attitude to the world and to himself which is a prerequisite for any creative activity, but which does not necessarily go into it. This co-creative attitude is deeper, more multidimensional and more dialectical. It contains the spiritual image of a person, his spiritual and cultural structure" $" 14$.

Such pedagogy believes that each individual is born with a huge innermost mental and spiritual potential that cannot be reduced only to evident manifestations of the personal world for us. The ideal for co-creation pedagogy is a teacher who educates on the principle: "the like causes the like, by all dimensions and levels of its personal world as a whole, because of the fullness of its openness and willingness to enter into co-involvement with own students to the end. He fills them with interests but even more so - with charisma which is always above any interests. It invites students not only to the world of cultural diversity, but also to sophisticated harmony" ${ }^{\prime 15}$. Priority should be given to the pursuit of such spiritual riches, in which the needs and interests are determined by value-semantic criteria, the dynamism of abilities - harmonization for the sake of loyalty to duty and purpose.

The unwillingness to understand and accept the spiritual foundations of education and upbringing, according to $\mathrm{V}$. Zenkovsky, leads to anthropological and pedagogical naturalism, which manifests itself in two

${ }^{14}$ Батищев Г. С. Три типа педагогики // Батищев Г. С. Избранные произведения. Алматы: Институт философии, политологии и религиоведения КН МОН РК, 2015. - С. 551.

${ }^{15}$ Батищев Г. С. Три типа педагогики // Батищев Г. С. Избранные произведения. Алматы: Институт философии, политологии и религиоведения КН МОН РК, 2015. - С. 551. 
forms - optimistic and pessimistic. In particular, "pessimistic naturalism does not only include the man in the system of mortal plain, but in no way wants to elevate him above another nature. By humiliating a person, putting him on a par with the animal world, such naturalism profanes a person"16. V. Zenkovsky was convinced that Christian anthropology, as a methodological basis, provides a new perspective for both theory and practice of pedagogy. Reflecting the complexity of the human personality, Christian anthropology is able to overcome pedagogical naturalism and return the mental and spiritual dimensions in the pedagogical space. It is impossible to understand the true essence of education and upbringing, without awareness of the essential characteristics of the image of being human - freedom, love, openness, creativity, value, uniqueness, integrity and indivisibility, catholicity, etc. "The application of the ideas of Christian anthropology to the understanding of the life of the soul and the internal dialectics of its searches is not necessary at all for one religious or even moral education, it is necessary for pedagogy as a whole. If it is true that everything is "personal" in a person, that is, everything is connected with the center of the soul, with its inner world; then it means that the ideas of Christian anthropology must either be connected with all processes of the soul or must be rejected whatsoever"17.

\section{Education and upbringing in the context of humane-personal pedagogy}

Alas, humane-personal pedagogy, "pedagogy of cooperation" did not originate in the pedagogical science, but in the practice of creatively oriented teachers. Moreover, it emerged and is increasingly becoming an alternative to authoritarian pedagogy, with its top-down approaches that have proven to be "viable" in the official pedagogical science.

Being aware of and highlighting the main aspects of the crisis of pedagogical consciousness, Sh. Amonashvili called for a change in pedagogical thinking. "The way out of the crisis is in the expansion of consciousness. Whatever conditions we define for a qualitative and perspective update of the world of education, the basis will be to change the paradigm of pedagogical consciousness. If our consciousness accepts the dimensions of spirituality, then gradually there will be a reorientation to the new values of education, to the values of humane pedagogy"18. Going beyond

16 Зеньковский B.В., Проблемы воспитания в свете христианской антропологии. URL: http://www.odinblago.ru/problemi_vospitania/

17 Зеньковский B.B., Проблемы воспитания в свете христианской антропологии. URL: http://www.odinblago.ru/problemi_vospitania/

18 Амонашвили Ш.А. Содержание и смысл гуманной педагогики. URL: http://gumanpedagog.org.ua/index.php?option=com_content $\&$ view=article\&id=4\&Itemid=15\&la $\mathrm{ng}=\mathrm{uk}$ 
the widespread definitions of humanism, Sh.Amonashvili focuses on the true essence of this concept, which reflects a person (mortal) who seeks to restore the Light, a connection with the Higher, the life of the Spirit. "The notions of spirituality and humanity are destined to change our mercantile, technocratic, materialistically concerned world, to counter the violence of the primary values - the sense of property, individualism, gluttony, the cult of utility, etc. by higher values, in the first place: faith in the higher, exalted, love for one's neighbor, conscience, service to the good"19. According to Amonashvili, the energy base of spirituality is faith, love and conscience.

The essence of the theory of humane-personal approach lies in the system of basic concepts: school, life, school of life, education, upbringing, child, mission, spirituality, development, freedom, cooperation, communication, teacher, student and lesson. The meaning of these concepts is revealed through the spiritual aspect.

According to the teachers-innovators - founders of the "pedagogy of cooperation" (Sh. Amonoshvili, S. Lysenkov, I. Ivanov, V. Shatalov, and B. Nikitina, etc.) humane pedagogy adopts the classical basis with the admonition, which leaves the possibility that the concept of spirituality, among other components, could contain the essence of a classical world religious doctrine. It is appropriate to mention Sh.Amonashvili, who emphasized pedagogical thinking as the unity of Faith and Reason. "Classical pedagogy is based on spiritual principles, on the principles of Christianity. It is worth noting that all classical pedagogy originated in the Slavic-European space, where the Christian religion has especially strong and wide roots. Height, eternity and wisdom are taken by the classical pedagogical teachings from the bowels of Christianity"20.

Therefore, as a sense of spirituality, representatives of the "pedagogy of cooperation" have assumed the assumption in three axiomatic postulates:

- reality of the Higher World, the Higher Consciousness, God;

- reality of the immortality of the human spirit and its orientation to eternal perfection;

- understanding earthly life as a segment of the path of spiritual improvement and ascension.

From these assumptions, we conclude about the philosophical perception of the child: "A child is a phenomenon, a command of the spirit in our earthly

19 Амонашвили Ш.А. Содержание и смысл гуманной педагогики. URL: http://gumanpedagog.org.ua/index.php?option=com_content $\&$ view=article\&id=4\&Itemid=15\&la ng=uk

Амонашвили Ш.А. Содержание и смысл гуманной педагогики. URL: http://gumanpedagog.org.ua/index.php?option=com_content \&view=article\&id=4\&Itemid=15\&la $\mathrm{ng}=\mathrm{uk}$ 
life. A child carries with it his life's mission, his life's mission, which he is called to serve. A child carries the primordial energy of the spirit - unlimited opportunities for spiritual perfection. From this it follows that a child is the unity of spiritual and natural entities, the essence of the union of Heaven and Earth, Soul and Body, a unique part of the Whole, unique among unique"21. This is, according to Sh. Amonashvili, an attempt to understand the spiritual aspect of humane pedagogical thinking, the meaning of the spiritual dimension.

Through consideration of this spiritual aspect, the content of the above concepts is revealed. This concept has a spiritual and religious origin, and is thought of as the process of perfection, the descent of the soul and the formation of human spirituality. It is no accident that the religious and philosophical basis of the ideas of Sh. Amonashvili, together with the works of famous philosophers and educators, became John of the Ladder's book The Ladder of Divine Ascent ${ }^{22}$. Based on his own spiritual experience John of the Ladder tells of the Christian virtues by which man lives as a "new man", that is, he becomes like Jesus Christ - the reverend. The Ladder describes the 30 stages of spiritual growth of each Christian. At the very end of this conditional "ladder of happiness" are the three greatest virtues - Faith, Hope and Love. Of which Love is the most important. That is God.

So the School is a ladder climb, a soul lift. The bearer of the school is the teacher, that is, the teacher is the school, the school in it, not outside it. The school is also interpreted (translated from Greek) as a house of joy. But this does not negate the difficulty of climbing, because true joy can only be experienced in the process of overcoming difficulties, in the process of climbing. One can recall M. Berdyaev, who wrote that the creative path is sacrificial and painful, but it is always a release from any oppression.

The system of humane-personal approach inspires the teacher to create such an educational process in which the Child in the life itself learns to change, improve, improve the conditions of this life, improve its quality, and not adapt to the already formed conditions. "Collaborative pedagogy (it is about the practices of well-known Soviet educators-innovators) was based on involving students in a common cause, so that it became important for each of them as a personal problem and therefore interesting, fascinating. Such a pedagogical space is a space of personal communication, which, in turn, forms the basis for the development of subjects in the sphere of joint

21 Амонашвили Ш.А. Содержание и смысл гуманной педагогики. URL: http://gumanpedagog.org.ua/index.php?option=com_content \&view=article\&id=4\&Itemid=15\&la $\mathrm{ng}=\mathrm{uk}$

22 Лествичник Иоанн, преподобный. Лествица или Скрижали духовные. URL: https://azbyka.ru/otechnik/Ioann_Lestvichnik/lestvitsa-ili-skrizhali-dukhovnye/ 
activity ... That is why the subject of study is no longer perceived as remote and abstract but acquires a concrete embodiment of living meanings addressed to the subjectivity of everyone ${ }^{\text {"23 }}$.

The concept of the School of Life, which is called the name of the school of humane-personal orientation, embraces exactly this meaning. Hence the principle that underlies the educational process in the School of Life: to develop and nurture life in the child through life itself.

In the context of the pedagogy of cooperation education is understood as the nourishment of the spiritual-spiritual axis of the individual. That is, there should be an ascent at the school, the formation of the very main thing in a person, which comprises the whole essence of his personality - soul and spirituality as universal. Such an ascent must be in advance of knowledge, ennoble it, and thus enlighten the mind. Spiritualized mind is a mind open to the encounter with a graceful Divine beginning, which enables creativity as a realization of man's divine beginning in all empirical, natural reality, man's realization of divine forces in the very real being of nature. Franciscus Assisiensis believed that there was no such knowledge that could lead to harmony. Another power, a different culture, leads a person to harmony - a culture of the heart! P. Florensky calls a man whose mind and heart are united by the energy of love. "The mind longs for love same as the heart, and blossoms only on reaching it. This is the secret of "love begets knowledge" or "knowledge is made by love" 24 . Love is the highest sense of our soul, the main sense of nature, the ultimate sense of divine. Without love there is no complete understanding; and one can prove that a wise man of excellent mind, but with a cold, unloved soul, is not a sorcerer of fruitful wisdom (M. Maksymovich). Verily, the living wisdom of the mind is established in love!

Education is not a molding of a person without the participation of the person who walks the path of development, adulthood and freedom. Education is the process of bringing the soul and heart of the child into the image of all the best (highest, spiritualized) heritage of human culture. "Everything what the participants in the pedagogical process (in other words, the content of education) talk about - in this way or another is a culture: all this is produced by humanity and passed on to the next generations as a gift... for meaningful and creative

23 Возняк В.С. Ситуація учнівство/учительство як вища форма розвитку взагалі // Феномен учнівства та учительства в історії філософії та культури (Тези Міжнародної наукової конференції "XXV Читання, присвячені 75-й річниці з дня смерті засновника Львівсько-Варшавсьвої філософської школи К .Твардовського”, 11-12 лютого 2013 року) / Відп. ред. В.Л. Петрушенко, редагування В.Л. Петрушенко, І.В. Карівець. - Львів : Вид-во “Ліга-Прес", 2013. - С. 96.

${ }^{24}$ Флоренский П.А.: Pro et contra: Личность и творчество Павла Флоренского в оценке pус. мыслителей и исследователей: Антология / Сост., вступ. ст., примеч. и библиогр. К.Г. Исупов. - СПб.: РХГИ, 1996. - С. 138. 
continuation, development - and above all - development into their subjectivity, into the subjectivity of everyone, into the individuality, subjective uniqueness. Transforming the content of education into culture in the full and true sense of the word ... the essence of the process of humanitarization of education ... And the most difficult and most important task of the teacher is to activate the subjectivity of culture so that it is taught and nurtured - in the sense of: animating by itself the soul, heart and mind of every pupil" 25 .

According to Sh.Amonashvili, the concept of the Teacher has the following semantic basis: the Spirit which creates, radiates and gives Light, Life (meaning of Life), Love, Knowledge, Wisdom. The terms Teacher and pupil contain the highest spiritual content, which has the same source as the basic concepts for humane pedagogy: School, Upbringing, Education, Enlightenment, Lesson and Life. The teacher and the pupil are the main general concepts; everyone else is grouped around and serves them.

Besides, this integrity of the concept of the Teacher-pupil, the whole palette of enclosed in profound allegorical formulas interdependence is revealed to us by the New Testament: "I planted, Apollos watered, but God gave the increase. So then neither he who plants is anything, nor he who waters, but God who gives the increase. Now he who plants and he who waters are one, and each one will receive his own reward according to his own labor. For we are Gods fellow workers; you are Gods field, you are God́s building."(1 Cor. 3: 6-9). The Teacher is the mediator between God and the infant soul. And if he does not plant and water with a feeling and understanding of deep responsibility and the same deep knowledge and creativity - how and when to water and nurture - then the grain of the spirit will not get the necessary development, the life and destiny of the child will be distorted, his mission will be distorted.

Thus, humane-personal pedagogy accepts the child as he is, sees the infinity of the child, realizes its cosmic nature, and leads, prepares it for service to the Universal. The co-authors of the Manifesto of Humane Pedagogy emphasize that the renewal of the educational process is that "every Child ought to be brought up by a Noble and Generous Person, develop spiritually and morally, master knowledge, which enhances his/her consciousness and leads to creativity and creation of good, learn to express, protect and affirm his/her free will in life, love for Motherland, appreciate and carefully treat the centuries-old culture of own people and humanity" ${ }^{\text {,2 }}$. The

${ }^{25}$ Возняк В. С. Культура як “третій суб’єкт” освітнього процесу // Проблеми гуманітарних наук. : збірник наукових праць Дрогобицького державного педагогічного університету імені Івана Франка / Ред. кол. Н. Скотна (головний редактор), О. Ткаченко (редактор розділу) та ін. Дрогобич : Вид. відділ ДДПУ імені Івана Франка, 2014. - Вип. 23. Філософія. - С. 20.

26 Маніфест гуманної педагогіки URL: http://gumanpedagog.org.ua/index.php?id= $127 \&$ Itemid=63\&lang=uk\&option=com_content $\&$ view=article 
goals and objectives of this higher form of pedagogical thinking are related to the creation of a refined person. Humane pedagogical thinking seeks to embrace the boundless and this is the power of educational systems and processes born in their depths.

In this context, very relevant are the peculiarities of Ukrainian education and upbringing, which in the humanistic sense enrich the world culture with a variety of national colors. And it magnifies a person who self-identifies with his or her tradition and parental customs and is at the same time open to the perception of the world culture.

We argue that under any circumstances, upbringing should be based on the principle of civic consent, understanding and cooperation of people, regardless of their ethnicity, religious beliefs, etc. It denies the confrontation of a man with another man, social groups, ethnic communities or denominations; is tolerant and engages in dialogue both within Ukrainian society and internationally. The establishment of the Ukrainian non-conflict lifestyle through education in the spirit of tolerance as an internal orientation and an active position of self-restraint, non-interference through manipulation into the spiritual world of the individual is a key task of the present which faces the national education, upbringing and political system of the society. Only this approach, according to the author, corresponds to a civilizational educational strategy that combines the positive features of pedagogues of traditional Eastern and anthropogenic Western civilizations, using national Ukrainian heritage in the fields of education and upbringing.

\section{CONCLUSIONS}

For a country seeking to become an active subject of international educational life, an important task is to understand not only its own educational and cultural tradition and to present to the world community its importance and importance, but also to update the educational space based on an understanding of the ontological nature of the phenomenon of education with its special feature - spiritual vector. And perhaps the most important task of education is to teach children "to use knowledge for their own individual and professional tasks" 27 .

In our opinion, the desire to help children to learn how to retain and preserve humanity in a globalized, digital world, and to expand the boundaries of internal freedom, must always remain paramount. And the ideal result of education and upbringing is "a person with a broad outlook who can make a principled stands, incorruptible and fearless, open and faithful, reliable and

${ }^{27}$ Гриневич Л. “Нова українська школа - це школа для життя у XXI столітті” URL: https://hromadske.ua/posts/nova-ukrainska-shkola-tse-shkola-dlia-zhyttia-u-xxi-stolitti-interviu-zministrom-osvity-i-nauky-ukrainy 
all-encompassing conscience of the whole world, who is able to measure his actions and his development in accordance with his value and sense justification, remembering how important is to be worthy of one's strength and talents" 28 .

This can be done only at the level of philosophical pedagogical thinking, which is aware of the ontological essence of human being in the dimensions of freedom, love, openness, creativity, intrinsic value, uniqueness, integrity and indivisibility, catholicity, etc. And the educational-pedagogical process is built on the basis of unconditional priority of spiritual and spiritual dimensions over object-organizational "factors". An example of such thinking is the spiritual experience of the founders and followers of humane-personality pedagogy, "pedagogy of collaboration", in educational institutions of which there is an ascension, the formation of the very main thing in man, which is the whole essence of his personality - soul and spirituality as the universal.

We emphasize that modern education is designed to help people learn to cognite, learn to make, learn to live and learn to live together. A paradoxical situation arises: life itself and its tasks are complicated and the education system is simplified. Ukraine is facing problems, the essence of which boils down not only to the adoption (or non-acceptance) of certain principles of the functioning of the educational system and its restructuring, the implementation of not only organizational and structural changes, but also the need for changes in thinking, mentality, system of attitudes and values. In order not to get lost in the big world, there are some strategies that require, first and foremost, multicultural education. It must be developed in two directions: knowledge and respect for all existing cultural systems and the possession of a personal culture born out of the synthesis of the national, civic, civilizational culture of the social environment.

\section{SUMMARY}

The proposed materials emphasize that the current crisis in education and the spiritual crisis in general actualize the need for philosophical and pedagogical comprehension of the spiritual dimensions of the educational process. It is proved that only such level of pedagogical thinking can overcome anthropological and pedagogical naturalism. This is clearly expressed in the practice of "pedagogy of collaboration", whose representatives understood the educational process as nourishing the spiritual-spiritual axis of the personality. Observing the ongoing reforms in the educational field, the author states that the education system should be an area free of unnecessary constant experiments. It implies tradition. In this

28 Батищев Г.С. Три типа педагогики //Батищев Г. С. Избранные произведения. Алматы: Институт философии, политологии и религиоведения КН МОН РК, 2015. - С. 552. 
context, Sh.Amonashvili's idea that classical pedagogy has always been based on spiritual principles and on Christianity in particular becomes very relevant today. The author emphasizes that affirmation of the Ukrainian non-conflict way of life through education in the spirit of tolerance as an internal orientation and an active position of self-restraint, non-interference through manipulation into the spiritual world of the individual is a key task of the present, which confronts the national education, upbringing and political system of the society.

\section{REFERENCES}

1. Амонашвили Ш.А. Содержание и смысл гуманной педагогики. URL: http://gumanpedagog.org.ua/index.php?option=com_content\&view= article\&id $=4 \&$ Itemid $=15 \&$ lang $=\mathrm{uk}$

2. Батищев Г.С. Три типа педагогики // Батищев Г.С. Избранные произведения. - Алматы: Институт философии, политологии и религиоведения КН МОН РК, 2015. - С. 546-554.

3. Возняк В.С. Культура як “третій суб'єкт” освітнього процесу // Проблеми гуманітарних наук. : збірник наукових праць Дрогобицького державного педагогічного університету імені Івана Франка / Ред. кол. Н. Скотна (головний редактор), О. Ткаченко (редактор розділу) та ін. Дрогобич : Вид. відділ ДДПУ імені Івана Франка, 2014. - Вип. 23. Філософія. - С. 14-28.

4. Возняк В.С. Ситуація учнівство/учительство як вища форма розвитку взагалі // Феномен учнівства та учительства в історії філософії та культури (Тези Міжнародної наукової конференції "XXV Читання, присвячені 75-й річниці з дня смерті засновника Львівсько-Варшавсьвої філософської школи К .Твардовського", 11-12 лютого 2013 року) / Відп. ред. В.Л. Петрушенко, редагування В.Л. Петрушенко, І. В. Карівець. Львів : Вид-во “Ліга-Прес", 2013. - С. 94-98.

5. Гегель - Крейцеру (черновик), конец мая 1821 г. // Гегель Г.В.Ф. Работы разных лет. В 2-х т. - Т. 2. / Вильгельм Фридрих Гегель; [ Сост., общ. ред. А.В. Гулыги]. - М. : Мысль, 1971. - 630 с.

6. Гриневич Л. "Нова українська школа - це школа для життя у XXI столітті" URL: https://hromadske.ua/posts/nova-ukrainska-shkola-tseshkola-dlia-zhyttia-u-xxi-stolitti-interviu-z-ministrom-osvity-i-nauky-ukrainy

7. Зеньковский В.В., Проблемы воспитания в свете христианской антропологии. URL: http://www.odinblago.ru/problemi_vospitania/

8. Ильин И.А. О сопротивлении злу силою // Ильин И.А. Путь к очевидности. - М.: Республика, 1993. - С. 6-133.

9. Лествичник Иоанн, преподобный. Лествица или Скрижали духовные. URL: https://azbyka.ru/otechnik/Ioann_Lestvichnik/lestvitsa-iliskrizhali-dukhovnye/ 
10. Лимонченко В.В. Опыт философской аналитики антропологического дискурса в Православии : монографія. - Дрогобич : Видавничий відділ Дрогобицького державного педагогічного університету імені Івана Франка, 2014. - 475 с.

11. Маніфест гуманної педагогіки URL: http://gumanpedagog.org.ua/ index.php?id=127\&Itemid=63\&lang=uk\&option=com_content $\& v i e w=$ article

12. Мовчан В.С. Глобалізація: до проблеми морального критерію процесу // Людинознавчі студії: Збірник наукових праць Дрогобицького державного педагогічного університету ім. I. Франка. - Дрогобич: Науково-видавничий центр ДДПУ ім. І.Франка, 2008. - С. 43-53.

13. Ортега-и-Гассет X. Миссия университета URL: http://www.management.com.ua/vision/vis009.html

14. Скотна Н.В. Особа в розколотій цивілізації : освіта, світогляд, дії: монографія. - Львів : Українські технологї, 2005. - 384 с.

15. Степаненко I.В. Духовність і душевність: категоріальні контури i функціональні можливості / І.В. Степаненко // Гуманітарний часопис 2005. - № 1. - С. 5-12.

16. Флоренский П.А.: Pro et contra: Личность и творчество Павла Флоренского в оценке рус. мыслителей и исследователей: Антология / Сост., вступ. ст., примеч. и библиогр. К.Г. Исупов. - СПб.: РХГИ, 1996. $-752 \mathrm{c}$.

17. Франк С.Л. Реальность и человек: метафизика человеческого бытия // Франк. С.Л. С нами Бог. М.: АСТ, 2003. - С. 133-436.

18. Хайдеггер М. Отрешённость / М. Хайдеггер ; [пер. с нем. А.С. Солодовникова] // Хайдеггер М. Разговор на просёлочной дороге / М. Хайдеггер. - М. : Высшая школа, 1991. - С. 102-111.

19. Черниговская Т. “Задача образования - научить сохранять человечность в цифровом мире”. URL: https://philologist.livejournal.com/ 10596473.html

20. Юркевич П.Д. Разум по учению Платона и опыт по учению Канта. / П. Юркевич // Философские произведения.. - М. : Правда, 1990. - C. 466-526.

\section{Information about the author: \\ Nadiia Skotna,}

Doctor of Philosophical Sciences, Professor, Rector, Drohobych Ivan Franko State Pedagogical University 24, Ivan Franko str., Drohobych, 82100, Ukraine ORCID: https://orcid.org/0000-0002-2929-8926 


\section{TURKISH PLOT OF THE BEGINNING OF RUSSIA'S TIME OF TROUBLES: THE "HOLY WAR" PROJECT: FALSE DMITRY I (LZHEDMITRY)}

\section{Vasyl Ulianovskyi}

\section{INTRODUCTION}

The idea of the "Holy War" originated in the Russian opinion-based journalism at the end of the XV - beginning of the XVI centuries and was documented in one of the lists of Nestor-Iskender's Tale of the Fall of Constantinople. The idea was presented in his work as a prophecy: "Руссии же род ... измаилита победят и седмахолмаго примут с преждезаконными сего..." . (Russian people ... will win the Ishmaelite and will obtain Sedmaholmago with its population). Later, Maximus the Greek justified the cronyism of Moscovia over all conquered Turks by the Orthodox people ${ }^{2}$. These ideas became especially significant when the throne of the Tzardom of Moscovy was taken by False Dmitry I, who did not only pretend to be, but was perceived by all Russian society as the true son of Ivan the Terrible. It is no coincidence that even the captain of the lifeguard of tsar Dmitry Ivanovich, the Frenchman Jacques Margeret, believed that Moscow State is - "one of the best defenders of Christianity" ${ }^{3}$. Indeed, the time of the Impostor's reign was the best moment for the most active propaganda of the idea of the "holy war" and the beginning of its real preparation.

\section{The concept and its impulses}

This idea blended seamlessly into the "sacral world" of False Dmitry I, and especially into the concept of plots and symbols of the special charisma of his royal/imperial power ${ }^{4}$. The appeal of the church leaders of the Christian East to the new tsar also played in favor of the situation. For example, the patriarch of Jerusalem Sophronius in his special message to the "son" of Ivan Vasyliovych called him "the most faithful, the most glorious, the highest, the most holy, the most orthodox, God-fearing ... beloved son of our humility" and the true successor

\footnotetext{
${ }^{1}$ Сперанский М.Н. Повести и сказания о взятии Царьграда турками (1453) в русской письменности XVI-XVII вв. // Труды отдела древнерусской литературы Института русской литературы (Пушкинского Дома) АН СССР. Т. 10. М., Л., 1954. С. 136-165.

${ }^{2}$ Максим Грек. Сочинение. Казань, 1860, ч. 2. С. 318.

3 Маржерет Яков. Россия начала XVII в. Записки капитана Маржерета / Публ. Ю.А.Лимонова. М., 1982. С. 138.

${ }^{4}$ For more details: Ульяновский В.И. Смутное время. М., 2006. С. 313-383.
} 
of Ivan IV. The patriarch wrote about his daily prayers for the tzarevich - "the treasure and the pearl of great price" $"$. Although all these epithets and titles were forms of Greek flattery, in the eyes of the Russians and Lzhedmitry I himself, he was put up to the pinnacle of the world Orthodoxy as the only earthly ruler - the unwavering support of the Orthodox Church. In the universal Orthodox context, the image of the new Russian tsar was risen above all other rulers. In fact, the eastern hierarchs began to create the image of an almost holy tsar liberator. In this context, the concept of "Moscow, the Third Rome" received not only theoretical but also practical meaning for the embodiment of "theocratic eschatology" when the tsar of Moscow received the "messianic task". Thus, the "idea of a universal Orthodox empire" began to loom again, which required the borrowing of the "text of imperial behavior"6.

The specified and non-specified factors of the "sanctification" of the power of the tsar Dmitry Ivanovich quite strongly influenced his personal consciousness and became a significant catalyst for his actions in order to develop the idea of "holy war". False Dmitry I, too obviously for his environment, began to dream of the glory of the great rulers of the world. At the Boyar Duma meetings, he compared himself to Alexander the Great ${ }^{7}$. Contemporaries-foreigners were surprised at his desire for selfaggrandizement: "Dmitry... was so arrogant, ambitious and haughty, that, like Alexander the Great, demanded respect from his servants and subjects, decent not to the emperor, king and sovereign, but to God, and magnified himself not as his predecessors and former great princes did, but calling himself the king of all kings. When he or his wife (i.e. Marina Mniszech, therefore, not earlier than May 1606 - V.U.), was going from one room to another, the bodyguards and the servants had to show their respect and diligence not in the way as it was done in the houses of the other secular sovereigns with a bow; no, they had to kneel. It is good only to God, and to no one else on Earth" ${ }^{\text {. }}$. Even a fairly neutral Greek hierarch who lived in Moscow for quite a long time, Archbishop Arseniy Elassonsky stated: "This tsar, being educated and wise, ruled the kingdom wisely, imitating the tsars, who ruled before him, and in

5 Российский государсвтенный архив древних актов (далее - РГАДА). Ф.52, оп.2, спр. 118; Опись архива Посольского приказа 1626 года / Публ. В.И. Гальцов. М., 1977. С. 75; Смутное время Московского государства (1604-1613 гг.). Вып.1: Акты времени Лжедмитрия І-го (1603-1607 гг.) / Публ. Н.В. Рождественского // Чтения в обществе истории и древностей российских. 1918. Кн. 1. С. 77-79.

6 Живов В.М., Успенский Б.А. Царь и Бог. Семиотические аспекты сакрализации монарха в России // Успенский Б.А. Избранные труды. М., 1994. Т. 1. С. 123-124.

7 Записки Станислава Немоевского (1606-1608 гг.) // Титов А.А. Рукописи славянские и русские, принадлежащие И.А.Вахрамееву. М., 1907. Вып. 6, приложения. С. 64-65.

${ }^{8}$ Петрей П. де Ерлезунда. История о великом княжестве Московском... М., 1867. С. 231; Буссов К. Московская хроника. 1584-1613 / Сост. А.И. Копанев, М.В. Кукушкина, ред. И.И.Смирнов. М., Л., 1961. С. 129. 
particular he strove to surpass them in every royal act and success, but become addicted to the glory of man more than to the glory of God"9. If you trust Conrad Boussov, according to him, False Dmitry I ordered to call himself "the tsar of all tsars"10. The Polish Jesuits who came to Moscow with the tsar were astonished at his conduct: "He puffed up to such an extent that not only equaled himself to all Christian monarchs, but even considered himself superior to them, and said that he would, like another Hercules, be a glorious leader of whole Christianity against the Turks. He arbitrarily accepted the title of emperor, and demanded to be called so not only by his own subjects, but even by foreign sovereigns... He was of such a great opinion about his wisdom, power, and justice that he did not consider anyone equal to him, and even despised some of the Christian kind and powerful monarchs. Finally, he considered his dominance to be eternal"11.

Moreover, the Impostor started diplomatic competitions for the official approval of his imperial title. He apparently continued the idea of Charles V of a universal monarchy, achieved through a victorious war with the Turks. The image of the ideal, pious, hereditary, God-crowned ruler, created by False Dmitry I actually had analogies with the theories of the "perfect sovereign"12. created by German, Italian, and Spanish thinkers. Tsar Dmitry was also familiar with Machiavelli's works on the sovereign, power and state, since he received a Latin edition of the publications from Antonio Possevino ${ }^{13}$.

The Impostor's idea of the "holy war" was closely linked to his "war" for the Caesarian title. This title indicated his intentions to rule over part of the world, it was, in the words of O. Ageeva, "the demand for the creation of bipolar Europe with two Christian imperial centers". On the other hand, "pretending to the imperial title, the sovereign seemed to admit that the title of Tsar-Caesar equals a lower-ranking title of king, depreciating the idea of Byzantine succession, which had no prestige in the west." The displacement of the "Byzantine heritage" (The Second Rome) was offset by the orientation to the First Rome, which was perceived as the only historical past of both western and eastern Europe ${ }^{14}$.

9 Дмитриевский А.А. Архиепископ Елассонский Арсений и мемуары его из русской истории: по рукописи трапезунтского Сумелийского монастыря. Киев, 1899. С. 105.

${ }^{10}$ Буссов К. Московская хроника. С. 129.

${ }^{11}$ Рукопись Яна Велевицкого // Записки гетмана Санислава Жолкевского о московской войне / Изд. П.А. Муханова. СПб., 1871. Приложения № 44. С. 171-172.

12 Ивонин Ю.Е. Имперская идея и проблема государственности в западной Европе XVI века // Вопросы истории. 1993. № 6. С. 31-44.

${ }^{13}$ Юсим М.А. Макиавелли в России. Мораль и политика на протяжении пяти столетий. M., 1998. C. 23, 31-41.

14 Агеева О.Г. Имперский статус России: к истории политического менталитета русского общества начала XVIII века // Царь и царство в русском общественном сознании. M., 1999. C. 135. 
In the message to Sigismund III Vasa of September 5, 1605, False Dmitry I was naming himself: "We, the most luminous and invincible monarch Dimitri Ivanovich, by the grace of God, the tsar and grand prince of all Russia, all Tatar kingdoms and other numerous possessions under Moscow monarchist power, sovereign and king", "we are crowned and aneled by our holy patriarch not only in the rank of the emperor of our vast possessions, but also in the rank of the king of all the Tatar kingdoms which from ancient times obeyed our monarchy" 15 . In this formula, the Impostor appropriated all the names/symbols of earthly power in the triple hierarchy: emperor - king tsar, emphasizing the equivalence of his power to the only modern emperor and height above the kings of the west and tsars of the east. In the order to Peter Chubarov, the envoy to Yuri Mniszech from September 21, 1605 there was another title: "The most eminent and invincible sole ruler, the great monarch Dmitry Ivanovich by the mercy of God the Emperor and Grand Duke of All Russia and all Tatar kingdoms and many other kingdoms, the king, tsar and possessor of Moscow monarchy subjects"16. "Invincible Caesar" was equated with the "Tsar of Glory" (let's remember K. Bussov's words, that the Impostor ordered to call himself "the tsar of all tsars"). Stanislav Borsha, who was among the mercenaries of the Impostor, remarked with amazement that the tsar "rejected that any sovereign in the world was equal to him and almost considered himself equal to God"17. For Polish ambassadors who refused to accept his imperial title, False Dmitry I postulated the idea that his power was God-given, so he also received the imperial title with power from God. So, "neither the Assyrians, nor the Medians, nor the Caesars of Rome had more rights and advantages for this title ... There is nobody equal to us in the Northern lands; no one rules us except God, but besides we distribute rights to the others... we are the supreme

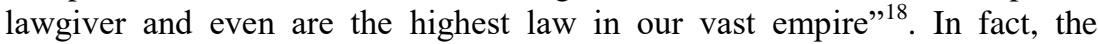
Impostor for the first time in Russia had developed the complex ideological system of the empire and formulated a meaningful filling of the title of emperor, relying on historical analogues and demonstrating considerable erudition.

It is interesting that the Polish ambassador, in response to the exorbitant ambitions of Tsar Dmitry Ivanovich, supposedly suggested him to conquer Crimea and Turkey first, in order to deserve the desired title. According to another, slightly modified version, the ambassador said: "Constantine the

15 Сборник русского исторического общества (далі - Сб. РИО). Т. 137. М., 1912. C. $748-754$.

${ }^{16}$ Там само. С. 187.

${ }^{17}$ Русская историческая библиотека (далі - РИБ). Т. 1. СПб., 1872. С. 424.

${ }^{18}$ Там само. С.412-414. 
Great divided the empire into eastern and western parts; the first passed to the Turks and the second to the Germans: when the Grand Duke defeats the Turks, and takes Constantinople, then he can take the title of emperor. Now his power in the south is completely unknown, and is limited only to the north and part of the east"19. It is noticeable that Rome, hoping for a real war of the Moscow kingdom with Turkey, started to title Tsar Dmitry according to his desire "emperor" and "invincible" 20.

In addition to the title, False Dmitry I also exploited other symbols of power that required the possession of the "holy land" - Jerusalem. In particular, he built for himself a throne similar to King Solomon's throne, as it was described in the Bible ${ }^{21}$. This fact further indicated that it was the third and the greatest king of Israel (Solomon) who was the model for the Impostor. During private receptions tsar Dmitry Ivanovich used the Iranian throne, presented in 1604 by Shah Abbas to Boris Godunov. This is not a coincidence: in the dream program of the "holy war", False Dmitry I intended to continue the idea of Boris Godunov linking up Iran to this action by making Shah Abbas his ally. Even the inscription on the tsar's silver award medals was in Latin and consisted of the title "By the Grace of God the Emperor of Russia", declaring the idea of the scale of power of the Moscow ruler. Most likely, these coins were oriented to the Western countries (the image of the tsar in the crown of the Western sample, the inscription in Latin). The domestic Russian version of the medals was designed to reward the upcoming "Turkish campaign" and contained double Russian and Western symbols. This was evidenced by the Russian-language inscription: “Дмитрий Иванович Божиею милостию царь и великий князь всея России и всех татарских королевств и иных многих государств Московской монархии подлеглых государь король и обладатель и цесарь России и Самодержец" (Dmitry Ivanovich by the mercy of God the Tsar and the Grand Duke of all Russia and of all the Tatar kingdoms and other many states of the Moscow monarchy subjects, the king, owner and emperor of Russia and the Autocrat). Thus, the existing three titles (Grand Duke, King, and Caesar) directly indicated the coexistence of the Russian and Western systems and focused on the possession of "many other states" 22 . Trying to overpass in

${ }^{19}$ Масса И. Краткое известие о Московии в начале XVII в. / Перев. А.А. Морозова, ред. Н. Рубинштейна. М., 1937. С. 132-133; Устрялов Н.Г. Сказания современников о Димитрии Самозванце. Ч. 1. СПб., 1859. С. 183, 344.

${ }^{20}$ Собрание государственных грамот и договоров, хранящихся в Государственной Комиссии иностранных дел (далі - СГГД). Ч. 2. М., 1819. С. 267-269.

${ }^{21}$ For more details: Ульяновский В.И. Смутное время. С. 352-355.

22 Лаврентьев А.В. Для какой цели были отчеканены “золотые” Лжедмитрия I? // Вспомогательные исторические дисциплины. Т.26. СПб., 1998. С. 204-207. 
everything his predecessors in the kingdom, Dmitry Ivanovich, according to Archbishop Arseniy Elasonskiy, was convinced that the Lord had saved him in his infancy from death (May 15, 1591), and he was appointed by the Lord for a world-class mission. The tsar wrote about this to his future father-in-law Yuri Mniszech: "We feel great grace of God over us, both in our health and in our state affairs"23. Actually, this God-defined mission, as the Impostor believed, was the "holy war" for the liberation of the Holy Land and the creation of anti-Turkish league.

\section{The idea of the holy war in the circle of the impostor}

The idea of the "holy war" implied not only the liberation of Christian shrines, but also the conquest of the entire Byzantine Empire, headed by Constantinople. Western diplomacy tried to impose this idea on Russian rulers throughout the sixteenth century. Jesuit Antonio Possevino promised the title of "Emperor of the East" to Ivan the Terrible if he would re-conquer Constantinople and all the former dominions of the Byzantine Empire. The mission of the crusade against the Turks was offered to Ivan the Terrible also by the ambassadors of the Austrian emperor. The Pope's envoy, Alessandro Comuleo, in 1594 sought to instill in tsar Fyodor Ivanovich the idea of establishing his authority over all Christians of the Greek rite. However, all these plans to involve Moscow in a global war with the Muslim world were unsuccessful, the attempt to involve Russia to the anti-Turkish league ${ }^{24}$. also failed. Only the "son" of Ivan the Terrible and the "brother" of Fyodor Ivanovich, not so much because of external influences, but in accordance with his own ambitions and sanctification of his authority, perceived the idea of the "holy war" as his "sacred duty".

It is considered that this idea was first introduced into his mind by representatives of the Catholic clergy while the Impostor still was in the Polish - Lithuanian Commonwealth. He made a promise, and of all his promises, given to obtain financial and military support, he only tried to put into action this one, after taking the throne. Interestingly, that already in his campaign against Moscow, False Dmitry I ordered to rename the city of Tsarev-Borisov (in honor of Godunov) to Tsargrad ${ }^{25}$. Of course, this small town could not be compared to Byzantine Tsargrad, but the action itself was already a symbol of intent.

\footnotetext{
${ }^{23}$ СГГД. Ч. 2. С. 227.

${ }^{24}$ Флоря Б.Н. Османская империя, Крым и страны Восточной Европы в конце XVI начале XVII в. // Османская империя и страны Центральной, Восточной и Юго-Восточной Европы в XVII в. М., 1998. Ч. 1. С. 53-54.

${ }^{25}$ Сборник материалов по русской истории начала XVII в. / Публ. И.М. Болдакова. СПб., 1896. С. 81.
} 
At the end of the summer of 1605, a couple of months after his enthronement, Dmitry Ivanovich started persistent negotiations with the Polish king and the Pope regarding the creation of an effective league and the beginning of the "holy war". On the orders of the tsar, the Ambassador to Sigismund III, Athanasius Vlasiev, in the autumn of 1605, had to lobby for the beginning of the war against the sultan for the liberation of Christians: "Greece, from where the roots and beginning of all piety, holy Bethlehem, where our Lord the son of God Jesus Christ was born and our Holy Word appeared, Nazareth and Galilee, the whole seaside country, and even the holy city of Jerusalem, where our Lord Jesus Christ, after having done many miracles, voluntarily accepted passion and death for our salvation and on the third day rose from the death". The Impostor took the fate of Orthodoxy and Christians very much to heart: "Our holy Orthodox Christian faith is everywhere subjected to neglect and humiliation; Christians are like sheep without a shepherd, and the wicked power of the unbelievers extends and expands everywhere - "about this ... we sincerely and heartily regret" ${ }^{\prime 26}$. In December 1605 , the tsar sent to Rome the attendant Jesuit Andrew Lavitsky for the purpose "to declare to the Pope that Dmitry wants to start the war against the Turkish Sultan" and to ask "to incite western Christian sovereigns to this war, especially the emperor of Rome and the king of Poland" ${ }^{27}$. In the personal epistle to Pope Paul V of November 30, 1605, False Dmitry I developed mainly the theme of the "holy war" ${ }^{28}$. Andriy Lavitsky managed to get the audience with the sick emperor Rudolf II in Prague to inform him about the tsar's plans for the "holy war" against the Porte and to request the support the action of the Impostor together with the king of Poland. Due to this information, the emperor even suspended talks with Turkish ambassadors regarding the peace treaty ${ }^{29}$. The information of the Impostor's intentions immediately ended up in the hands of the agent of the Republic of Venice Francesco Soranto, who reported to Doge: "It is not without the likelihood that one day he will be given the free hand to move against the Turks, it would be the best possible reason in case if he would decide to do this soon, to put on guard possible thoughts about peace" ${ }^{, 30}$. The most reputable Vatican expert on eastern Europe, Jesuit Antonio Possevino, also developed the idea before the Duke of Tuscany that Muscovy, Poland, and the emperor could oppose the Ottomans.

\footnotetext{
${ }^{26}$ РИБ. Т. 1. С. 45-46.

${ }^{27}$ Рукопись Яна Велевицкого. С.137; Магилина И.В. Россия и проект антиосманской лиги в конце XVI - начале XVII вв. Волгоград, 2012. С. 252.

${ }^{28}$ СГГД. Ч.2. С. 231-234.

${ }^{29}$ Александренко В.Н. Материалы по Смутному времени на Руси XVII века // Старина и новизна. М., 1911. Кн.14. С. 352.

${ }^{30}$ Там само. С. 382.
} 
The plan of the Impostor was elaborated in details in the letter to King Sigismund III, the text of which was preserved with defects, but it is the most important of all documents, therefore it requires a detailed citation: “Для грехов всего православного християнства и за незгодою всих великих господор християнских, неприятель крижа святого Христова, турский султан опановал веле христианских панств, а наболей грецких [...] , на которой есть корень и голова всего благословенства $[\ldots]^{*}$, где пан наш Иисус Христос, Сын, Слово Божое, народитися злюбил, и святый $[. . .]^{*}$, Галилею и поморские земли вси, и самое там-то святое место Ерусалим, где пан наш Иисус Христос много чудов учинивши, муку и смерть для збавленья нашого доброволне под $[. . .]^{*}$ и встал $з$ мертвых $[. . .]^{*}$ Тые вси святые места видим отриманы измаилскими гордыми руками, а нашу святую правдивую православную хрестиянскую веру отвсюль видим $[. . .]^{*}$ и понижоную, яко овца не маючи пастыря; а зтого, поганьская владза везде роз[...]*, и много хрестиянских панств под свою владзу окрутне $[\ldots]$ ?, а ничим насытитися не могут... Того мы великий господарь цесарь, великий князь Дмитр Иванович всее Руси самодержца, жалеем с души и сердца, и того у пана Бога просим и с пильностию промышляти хочем, жебы нам всим великим господаром христианским быть межи собою в приязни и в милости и в едноченью, жебы нашим великих господаров християнских стараньем християнство з рук бусурманских освобождено было, и рука бы наша $[. . .]^{*}$, а поганьская была понижена"31. (For the sins of all Orthodox Christianity and considering the discord of all great Christian lords, the enemy of the holy Creed of the Christ, the Turkish sultan captured many Christian lands, and considerable part of Greece [...] *, where there are roots and principles of all the blessings [...]* where our Lord Jesus Christ, the Son of God, and the Word of God, appeared, and the saint [...]*, all Galilee and Pomeranian lands, and the holy place of Jerusalem, where our Lord Jesus Christ made many miracles, and voluntary accepted travails and death for our deliverance $[\ldots] *$ and rose from the dead [...] * All these saint places are under the proud hands of Ishmaelite, and our true holy Orthodox faith is suppressed[...] * our pride is mortified like a sheep without shepherd; and nonChristian power is ruling [...] *, and many Christian nations are under their power [...] ?, can't get enough of anything. We, the great ruler Caesar, Grand Duke Dmitry Ivanovich, sole rule of all Russia, regret with all our heart and soul, and ask our Lord to take care of us to unite all Christians to be together in

${ }^{*}$ Lacunes in the text of the document.

31 Акты, относящиеся к истории Западной России, собранные и изданные Археографическою комиссиею / Ред. прот. И. Григорович. СПб., 1851. Т. 4: 1588-1632 гг. C. 252 . 
affection and mercy, at the same time with the efforts of all our Christian landlords it is necessary to liberate the Christianity from the hands of infidels, and our hand would [...] *, and the hands of heathen will be sublated). Consequently, False Dmitry I made a major emphasis on releasing the main shrines of the Christian world related to the terrestrial life of Jesus Christ. According to him, these shrines served to consolidate Christian west and Christian east to oblige all Christian countries with their rulers to take care of the liberation of these shrines from the Muslim conquest. It was some kind of continuation of popular ideas spread in Russia during the time of Ivan the Terrible about the tsar - liberator, the "emperor of the whole east," who would liberate St. Jerusalem. If earlier and later (under Patriarch Nikon) the theories of "second Constantinople" and "new Jerusalem" in Russia / Moscow were developed, the Impostor intended to possess both the first Constantinople and the first Jerusalem, putting himself into the sacred context of the New Testament history and sacred-tsarist context of the first and most powerful Christian empire. By placing himself into the sacred world of such global proportions, False Dmitry I sought to prove to west the validity of his claims to the highest symbols of sub-celestial power, to show to the whole Orthodox world his piety and loyalty to the Orthodox Church, to win faith in his messiahship among the peoples of the Balkans and Greece, and finally to reach the desirable image of the Christian Ruler.

\section{Specifics of actions: diplomacy}

Was the idea of the "Holy War" real in 1605-1606? Was it just beautiful concepts and words or Tsar Dmitry really thought in terms of the holy war and was in preparation to the military actions? The multifarious sources available allow us to answer these questions quite objectively.

From the summer of 1605 , tsarist diplomacy started to verify broadside public sentiment of potential partners of the "Holy War". The envoy to Poland, Peter Chubarev, received the order (July 21, 1605) to inquire into the state of relations of the Polish king with the Crimean khan and the Turkish sultan. He had to clarify if the king made peace with the sultan, who was the initiator of peace, and who was the first to send gifts to the enemy. The envoy also had to find ways to get information about emperor Rudolf's II relationship with the sultan: whether they were still at war or reconciled, whose troops incurred more losses during the military operations, whether the emperor had allies and what kind of relations he had with the Polish king. All this information Chubarev had to "проведати тайно у всяких людей; и что проведает, то все записати себе тайно" ${ }^{32}$. (find out secretly from all manner

\footnotetext{
${ }^{32}$ Сб. РИО. Т. 132, С. 189-190.
} 
of men and make his records secretly). Through another envoy, False Dmitry I declared to the royal court that he was ““со всею ратью на весну готов” (ready with all his army for the spring campaign) "but he never received clear response from Poles ${ }^{33}$. Therefore, in the next decree of the messenger, the tsar was reprimanding the Polish side quite undiplomatically: "Our Highness invincible Caesar intends to wage war with evil people only in favor of the glory of God and the holy faith, without any other objectives. If, however, the king instructed you only to know our thoughts and not to do anything afterwards, it will be cunningness and cajolement ${ }^{\prime 34}$. At the same time, Tsar Dmitry tried to involve unsuccessfully England, France, Spain and the Republic of Venice to the anti-Turkish coalition ${ }^{35}$. Thus, the main reliance of False Dmitry I was made on the Papacy: On November 30, 1605, in the personal epistle to the Pope, the tsar appealed persistently to start the war with the Porte for holly relics and asked the Pope to influence the emperor and other Catholic rulers of Europe ${ }^{36}$. His Jesuit envoy Andriy Lavitsky had to inform the Pope that the tsar was ready to launch hostilities as soon as the emperor and the king of Poland would agree to support his actions ${ }^{37}$. Realizing that the attempt to induce the practical actions of the western rulers is unrealistic, Dmitry Ivanovich addressed to Paul V with a special message of February 5, 1606, to help at least to ensure that the emperor would not conclude peace with the sultan In response, the Vatican tried to push the tsar to start real military campaign without assistance. Pope's nephew Cardinal Scipio Borghese, in response to the tsar's appeal to the pontiff, assured him that all Catholic monarchs would support the Moscow ruler in this "holy cause". To compliment the False Dmitry I, the Cardinal called him "the most powerful" commander of the "giant army", convincing that the tsar himself will be able to defeat the Porte without any help of the other rulers, as "everybody is looking forward to his glorious victories." At the same time the pontiff promised only to set the tsar as an example to all other rulers and to cover his name with "immortal fame" "38. Jesuit Antonio Possevino, an expert on "Moscow affairs" at the Vatican, also directed papal diplomacy to push the tsar to start hostilities against Turkey, while at the same time offering to officially reanimate the anti-Turkish league by attaching to its members (Holy

${ }^{33}$ Полное собрание руських летописец (further - ПСРЛ). Т. 14. М., 1965. С. 68.

${ }^{34}$ Сб. РИО. Т. 132. С. 191.

35 Александренко В.Н. Материалы по Смутному времени на Руси. С. 233; Устрялов Н.Г. Сказания современников о Димитрии Самозванце. Ч. 1. С. 305, Ч. 2. С. 189; Hirschberg A. Dymitr Samozwaniec. Lwów, 1898. S. 153.

${ }^{36}$ РГАДА. Ф. 78, оп. 1, д. 3; СГГД. Ч. 2. С. 231-234.

${ }^{37}$ Рукопись Яна Велевицкого. С. 137.

${ }^{38}$ Рукопись Яна Велевицкого. С. 146. 
Roman Empire and Polish-Lithuanian Commonwealth) Holy Moscow Kingdom as affiliated member ${ }^{39}$. Polish nuncio Claudio Rangoni also had the task of calming of False Dmitry who was disillusioned by the inertia of the west over the "holy war". The Cardinal wrote to the tsar on February 25, 1606, that Pope Paul V had directed all his forces to establish a real alliance between Warsaw and Moscow in the planned war against the Porte, and Moscow's participation in this fierce action would take away "wings and a right shoulder" 40 from Turkey. Why did the papal curia push so hard the Impostor? The answer was given by the English agent Plessen in his special analytical report to London on September 3, 1605: The Vatican believed that the Tsar of Moscow could provide 150,000 armored soldiers, and thus the pontiff, and the western rulers could do nothing from their side ${ }^{41}$. All these attempts were defeated by the intransigence of the Polish king Sigismund III. In response to an attempt by False Dmitry I in a personal letter dated November 23, 1605, to persuade the king to ally and start a military march to the east, the king replied that he had a problematic relationship with the empire. Even Cardinal Rangoni, in his letter of February 25, 1606, explained to the tsar that he had not succeeded in overcoming "many obstacles" on the way to an agreement between the king and the emperor, "the Poles and the Germans by their nature disagree with each other, so the king does not consider it possible to conclude a treaty against the Turks with the emperor ${ }^{42}$.

\section{Specifics of actions: military preparation}

At the long last, Tsar Dmitry started preparations for a military campaign unilaterally. This is evidenced by scattered and fragmented, but indisputable sources. First of all, the tsar set out to raise money for a military campaign. He collected money mainly from church structures. In particular, in the JosephVolokolamsky and Novodevichy monasteries the Impostor borrowed 3 thousand rubles from each of the monasteries in Ciril-Belozersky 5 thousand, and in the Trinity-St. Sergius Monastery - 30 thousand, concerning other monasteries the information is not preserved. In addition, a special military tax was imposed on the monasteries. It was possible to find out this data only with regard to those church structures that kept the books of expenses for 1605-1606. In particular, the Cyril-Belozersky monastery in April 1606 paid a special tax “в государев царев и великого князя Дмитрия Ивановича всея Руси в полскои" (to the sovereign tsar and Grand Duke

\footnotetext{
${ }^{39}$ Александренко В.Н. Материалы по Смутному времени на Руси. С. 381-382.

${ }^{40}$ СГГД. Ч. 2. С. 272-275.

${ }^{41}$ Александренко В.Н. Материалы по Смутному времени на Руси. С. 242.

${ }^{42}$ СГГД. Ч. 2. С. $273-274$.
} 
Dmitry Ivanovich of all Russ for polskoye (i.e., in the field, in the southern steppes - V.U.) "поход за ратные люди" (military campaignThe monastery was also obliged to horse the army. For example, in May 1606 Krasnokholmsky Monastery of St. Nicolas provided “для полского походу" (for the field campaign) their servants and 35 stallions. From the JosephVolokolamsk Monastery, the horses were delivered,"под стрельцы, под Елец на государеву службу" (for streltsy, under Yelets for the sovereign service) for this purpose more than 297 rubles were collected from the monastic peasants, 8 horses and 8 rubles to feed the horses were taken from the village Ostashkovo alone ${ }^{43}$.

Following the tsars order, weapons were intensively manufactured in the country. This was testified by Swedish resident Petrus Petrej. He wrote that False Dmitry I "commanded to mold a fair amount" of canons ${ }^{44}$. Conrad Bussov, who lived in Moscow at that time and served for the Impostor, also wrote about the mass production of mortars and guns. He testified that the tsar sent a considerable amount of artillery in winter "to Yelets, which is located at the Tatar border," as he had the intention to "visit the Tatars and the Turks" 45 in the summer of 1606. The Dutch merchant Isaac Mass, who also lived in Moscow, not only confirmed the production of a large number of mortars and guns, but also indicated that the Impostor had personally tested them ${ }^{46}$. In 1818, a cannon was found in the Kremlin's armoury with the inscription: "Божиею милостию повелением великого государя царя и великаго князя Димитрея Ивановича всея великия Росия самодержца в первое лето госудрства его зделана бысть сия пушка в царьствуюшем граде Москве в лето 7114 (1605 г. - В.У.) месяца сентября в 27 день. Мастер Ондреи Чохов, а делал пушечной литец Проня Федоров". (Ву the grace of God, by the order of the great sovereign ruler Tsar and Grand Duke Dmitry Ivanovich, the great autocrat of Russia in the first summer of his sovereignty this canon was made in the reigning city of Moscow in summer of 7144 (year of 1605 - V.U.) in the month of September, 27th day. Master workman Andrey Chekhov, and gun was casted by Pronia Fedorov). This cannon being preserved by miracle, since Peter the First, when the cannon was located, banned to recast it. The cannon weighed 116 pounds and 32 feet $^{47}$.

${ }^{43}$ РГАДА. Ф. 1192, оп. 2, спр. 15, арк. 133-141, спр. 16, арк. 229.

44 Петрей П. де Ерлезунда. История о великом княжестве Московском... М., 1867. C. 210 .

${ }^{45}$ Буссов К. Московская хроника.. С. 111.

${ }^{46}$ Масса И. Краткое известие о Московии. С. 118-119.

${ }^{47}$ Российская нациоанльная библиотека. Отдел рукописей (далі - РНБ. ОР) Ф. 328, д. 91, д. 67-68 об. 
It is likely, that a mobile fortress was also planned for the military actions; later on, after the murder of False Dmitry I, Russian publicists interpreted this

fortress as the "hell" ("inferno"). They used this image to demonize the tsar whom they served and worshiped during his life. Neutral, though not positively disposed to Tsar Dmitry Ivanovich, the Dutch merchant Isaac Mass, who himself saw the fortress, wrote about it: "He ordered to make a monsterfortress, moving on wheels, with many small field cannons inside and various kinds of firearms, to use this fortress against the Tatars and thereby to frighten both themselves and their horses, and indeed this was invented by him very cunningly... and it was very skillfully made and all painted; elephants were depicted on the doors, and the windows were similar to the gates of hell, and they had to spew fire, and below were small windows similar to the heads of devils, where small guns were placed. Truly, if this fortress could be used against such enemies as the Tatars, it would immediately lead them into confusion and put the army to flight, because it was very skillfully invented. Due to this Muscovites called the fortress the monster of hell, and after the death of Dmitry, whom they called a sorcerer, they said that he locked the devil there for a while" 48 .

False Dmitry I was taking seriously the preparation for the great war. $\mathrm{He}$ himself trained the noble regiments. Not only foreigners (Isaac Massa), but also the Russian elite (Prince Ivan Katyrev-Rostovsky) testified that he "himself was a brave warrior ..., possessed incredible strength in his hands", "конское рыстание любляше, на враги свои ополчитель смел, храбрость и силу имея, воинство же вельми любяше"49 (loving horse whinny, he was courageous to fight his enemies, having brevity and power, he loved his troops). So, according to the eyewitness, the tsar "himself trained his horsemen, they were brave fellows and nobles of good families, and the tsar gave them good remuneration ..."

False Dmitry I tried in many ways to conduct surveillance in Sublime Porte using including captives as well. For example, he ordered to reward "Turkish captive Yakushko Fedorov, son of Nedoshyvok" 1605, the Turkish captain "Dus Bakhmet..., who caused great damage all over the river Don" 52 and was captured by Cossacks "located near Azov" was brought to Moscow according to the special order of the tsar.

${ }^{48}$ Масса И. Краткое известие о Московии. С. 119.

49 Там само. С. 118; Памятники древней русской письменности, относящиеся к Смутному времени // РИБ. Т. 13. СПб., 1909. С. 622.

${ }^{50}$ Масса И. Краткое известие о Московии. С. 121.

${ }^{51}$ РГАДА. Ф. 210, десятни, д. 223, л. 80.

${ }^{52}$ Масса И. Краткое известие о Московии. С. 121. 
Yelets was determined as the main starting point of the military campaign, from where the troops had to go to the Turkish fortress of Azov. The second point of rendezvous was Astrakhan, from which the detachments also had to go to capture Azov. Conrad Boussov observed, as from the winter of 1606, "big quantity of ammunition, supplies and provisions was sent to Yelets, a town on the Tatar border; everything was brought there to accompany the army, so that by the spring they had stored large quantity of flour, powder, lead, fat, and all kinds of other things for three hundred thousand men, and it was ordered that all should be kept until his (Dmitry) arrival"53. Isaac Mas also confirmed this information: "a lot of ammunition and supplies were sent to the town of Yelets in order before everything else to attack Tataria" According to Polish mercenary Martin Stadnitsky, False Dmitry I concentrated near Moscow about 18,000 soldiers to march on Crimea, "where troops were sent daily" "55. This Moscow-area army did not manage to enter the campaign and was partially involved in the uprising against Tsar Dmitry Ivanovich, organized by Vasily Shuisky. Even the publicists of the Troubled Times, who of course defamed the impostor, pointed to his military preparations. For example, Abraham Palitsyn remarked: "Послав на Елец много избранного наряду пушечно и спустоши Москву и иныя грады тою" (Hе sent to Yelets a lot of ammunition and thus devastated Moscow and other cities). He noted that part of the troops had to raft along the Don river and the other part to move by land ${ }^{56}$. This Moscow-area army did not manage to enter the campaign and was partially involved in the uprising against Tsar Dmitry Ivanovich, organized by Vasily Shuisky. Even the publicists of the Troubled Times, who of course defamed the impostor, pointed to his military preparations. For example, Abraham Palitsyn remarked: “Послав на Елец много избранного наряду пушечно и спустоши Москву и иныя грады тою" (Hе sent to Yelets a lot of ammunition and thus devastated Moscow and other cities). He noted that part of the troops had to raft along the Don river and the other part to move by land ${ }^{57}$.

How numerous were the troops of the Impostor in the Crimean-Azov area? Jesuit Caspar Savitsky, who had personal contacts with the tsar indicated that the tsar himself named the figure of 160 thousand warriors. To tell the truth, some contemporaries (K. Bussov) mentioned fantastic

\footnotetext{
${ }^{53}$ Буссов К. Московская хроника. С. 111, 125.

${ }_{55}^{54}$ Масса И. Краткое известие о Московии. С. 143.

55 История Димитрия царя московского и Марины Мнишек. Дневник Мартына Стадницкого / Публ. А.А. Титова // Русский архив. 1906. № 10. С. 161.

${ }_{56}$ Сказание Авраамия Палицына / Публ. О.А. Державиной, Е.В.Колосовой. М., Л., 1955. C. 114, 264.

${ }^{57}$ ПСРЛ. Т. 14. М., 1965. С. 68.
} 
figure of 300 thousand. Some fragmentary specifics of the troops in Yelets can be found in the Murom Desiatnia of 1606, where the provision to local nobles of 50 quarters of the land for "за елецкую службу" 58 (Yelets service) was documented. False Dmitry I intended to come to Yelets before the beginning of the military expedition to personally lead the army. However, British diplomat William Smith reported that the "Turkish march" should have been headed by the most loyal to the tsar boyar of Moscow, Peter Basmanov, and Smith did not rule out that Basmanov had to lead the army against Sweden, not Turkey ${ }^{59}$. Even during the exercises near Vyazma, Tsar Dmitry Ivanovich, seizing the conventional fortress, mentioned to his people: "God willing, we will take Azov in the same way over time" ${ }^{60}$. Even during the exercises near Vyazma, Tsar Dmitry Ivanovich, seizing the conventional fortress, mentioned to his people: "God willing, we will take Azov in the same way over time" ${ }^{, 61}$ (ordered for all Russia and for many Poles to be prepared to go to Azov). Near Azov, Cossacks from the Don river were also very active, preparing to assault the fortress. Azov was an important Turkish fortress that controlled the Caucasus. Equally important was the city of Astrakhan. The fact that the troops were also concentrated here is evidenced in the desiatnias of the involvement of noblemen. For example, on December 28, 1605, in the Arzamas desiatina there were records on the distribution of salaries to "детем боярским, которым велено бытии на государеве службе в Астрахани" 62 (boyar children who were ordered to be in the sovereign's service in Astrakhan). In Murom's desiatnia of 1606, 20 noblemen were named, who “в прошлом 113 $(1605$ г. - В.У.) году сказана была государева царева и великого князя Дмитрея Ивановича всеа Руси служба в Асторахан" (in the past year of 113 (1605 - V.U.) were on military service of the tsar and grand prince of all Russia Dmitry Ivanovich in Astorahan) "their allowances have been increased twice. Presumably, for this correction, the princes KulunchakMurza and Yemekiy-Murza Yenikeyev Tenishev, were ordered to mobilize 700 princes $^{63}$, murzas, cossacks and Mordvinians “ на государеву службу со всем служебным нарядом" (for a sovereign service with all official attire $)^{64}$. In addition, the cossacks were given the task of "knock down" with

${ }^{58}$ РГАДА. Ф. 210, десятни, д. 6, л. 5 об., 32 об.

${ }^{59}$ Александренко В.Н. Материалы по Смутному времени. С. 253.

${ }^{60}$ Устрялов Н.Г. Сказания современников о Димитрии Самозванце. С. 53-54.

${ }^{61}$ Сказание Авраамия Палицына. С. 114, 261.

62 Юшков А. Акты XIII-XVII вв., представленные в Разрядный приказ представителями служилых фамилий после отмены местничества. Ч. 1. М., 1898. С. 285.

${ }^{63}$ РГАДА. Ф. 210, десятни, д.6, л. 29-30, 37.

${ }^{64}$ РНБ. ОР. Ф. 464, спр. 5, арк. 1-2. 
the Turks from the fortified town of Terek ${ }^{65}$. Researchers believe that in the spring of 1606 the troops, headed by F.I. Sheremetyev and I.N. Saltykov were dispatched to Astrakhan ${ }^{66}$.

At the same time, False Dmitry I was preparing military campaign to Crimea, since for this purpose, from September 1605 it was decided to cast the cannons. However, at first, during his march on Moscow to reconquer the throne, Tsarevich Dmitry tried to relay on the Crimean khan through special envoy Konstantin Shirkov, but in Crimea people did not believe him ${ }^{67}$. Crimean ambassador Jan Akhmet Chelibey (Chelebi) reported to Boris Godunov in November 1604, referring to a man "Димитреем называют, царя Ивана сын, а мы для того не ведаем, прямой ли он царя Ивана сын или непрямой, толька деи меж дву государей смуту учинил велику" (who is called Dmitry, tsar Ivan's son, and we do not know if he is the son of tsar Ivan's direct or indirect, but his deeds between two sovereigns made real riot). Moreover, the ambassador offered Khan's assistance particularly to Godunov: "И царь (хан - B.У.) для государя хошь то сперва в Киев пойдет"68 (And the tsar (khan - V.U.) for the sovereign may go to Kiev first). The Khan's ambassador reported that King Sigismund III had sent to Khan his envoy, Jan-Anton Cherkashin, with a proposal to assist False Dmitry I in the war against Godunov ${ }^{69}$. However, the ambassador had seen in Moscow the collapse of the Godunov dynasty and the reign of Dmitry Ivanovich. On July 8,1605 , the embassy clerk Athanasius Vlasiev began to negotiate with the Crimeans on behalf of Tsar Dmitry on "friendship and love." The ambassador had to say in response that the Crimean Tatars "rejoiced" the reign of Ivan the Terrible true son, as well as in the release by him of all the prisoners of Boris Godunov. At the same time, the ambassador pointed at his own state similar to imprisonment and asked to be released and permitted to go to Crimea. He asked as well to return old khan's letters to Tsar Boris, where “царское имя писано не по пригожу"70. (royal name was not mentioned correctly). On July 21,1605 , the Crimean embassy was received by Tsar Dmitry Ivanovich himself, on the same day with the reception of the Tatar king UrazMohammed of Kasimov and the Swedish prince Gustave in the Golden Chamber. The tsar was in ceremonial vestments sitting on the "throne of SolomonHe spoke to the Crimeans about the reign on the throne of

${ }^{65}$ СГГД. Ч. 2. С. 265-266.

66 Лисейцев Д.В. Русско-турецкие отношения в начале XVII века: от конфронтации к сближению // Отечественная история. 2002. № 5. С. 171.

${ }^{67}$ Смутное время Московского государства (1604-1613 гг.). Вып. 1. С. 251.

${ }^{68}$ Там само. С. 175.

${ }^{69}$ Там само. С. $180-182$.

${ }^{70}$ Там само. С. $186-187$. 
"his father" and "his brother", to maintain peace, love and friendship with the khan; he gave valuable gifts to the ambassadors and let them go to Crimea ${ }^{71}$. Police officers were instructed not to allow the ambassadors to speak with the local population and to send dispatches to Crimea. The Crimeans had an order to stay in Mtsensk and wait for the royal envoy to the khan, together with whom they had to go to Crimea. From October 1605 until April 1606, quite a large embassy (about 150 people and twice as many horses) had to reside in Mtsensk and Novosil without sufficient food and feed. The police officers were informing Moscow regarding all trivialities and incidence with the Crimeans. The tsar (the title of "Caesar" was used in the orders) frightened the police officers to be punished by hanging them, if at least one Tatar escapes and go to Crimea $^{72}$. At the same time, a plan for a military campaign to the South-East and Crimea was under development. It was only in March 1606 when the royal envoy to the khan - Afanasii Melentiev Kurlukov arrived in Livny, with a new Crimean envoy Alash-bogatyr (he came to Moscow in January 1606 with the royal messenger Konstantin Shirkov). Russian authorities have made every effort to prevent the Crimeans from learning about military preparations and plans. Moreover, at the beginning the police officers were ordered to hide the Crimean embassies from each other, only on March 21 both embassies were allowed to meet together, but provided that there would be present a secret person among the Russian nobles who spoke Tatar language and could understand what the Crimeans were talking between themselves. However, the Crimean ambassadors were not naive, so in the presence of Muscovites they spoke only about the tsar, his generous gifts and praised the Moscow ruler ${ }^{73}$. Jan Ahmet Chelebius deliberately said that he had remembered the secret words of the tsar, to be rendered a verbatim to the khan 74. The tsar's envoy Athanasius Kurlukov had to speak in the presence of the Crimean ambassadors mentioning that after the reign of the true son of Ivan the Terrible, "sovereigns of many states" sent their embassies: the emperor of Rome, the kings of Poland and Denmark "and other sovereigns" with greetings, and the new tsar sent his embassies "во все страны" (to all the countries). However, Athanasius did not succeed in getting anything special from the Crimeans, only information that "Можары с турскими не в миру" (Mozars with the Turkish are not at peace) and both sides are trying to enlist the support of the $\mathrm{khan}^{75}$. Only on April 12, all the three embassies (two Crimean and Moscow) left to Crimea following the royal order. In such a

\footnotetext{
71 Там само. С. 188-189.

72 Там само. С. 196-245.

73 Там само. С. 249.

74 Там само. С. 250.

75 Там само. С. 250-256.
} 
way, the Tsar Dmitry Ivanovich tried to lull the vigilance of Kaza-Giray. After receiving all the information, Tsar Dmitry believed that the moment to start a military campaign against the Porte, weakened by rebellion and the necessity to fight on several fronts, was quite right. But the Turks also had their informants. The French ambassador to Istanbul, Jean de Gontaut Biron, baron de Salignac, informed King Henry IV that the Turkish authorities already knew about the preparations by the tsar of Moscow for the march on Azov and further into the main Turkish possessions ${ }^{76}$. Greek merchants in Istanbul also have heard about the preparations and reported: "Prince Dmitry intends to attack Turks; this is a great luck and help for us" ${ }^{\text {"77. }}$.

Consequently, not having received the support of the west, Tsar Dmitry Ivanovich decided to carry out a large-scale plan to confront the Muslim world on his own. In doing so, he intended to reinforce his title of "invincible", the desire to become the "emperor of the East", the ruler of the Holy Land and the main relics of the Christian world. This was the path at the same time of Alexander the Great and the biblical king Solomon, with whom the False Dmitry I sought to "equalize" in glory, grandeur, special sacrament and God's mercy.

The Impostor discussed his anti-Turkish plans in private conversation with Carmelite Fathers who were traveling through Moscow to Persia. One of the Carmelites, Father Paul-Simon wrote about the new Russian tsar: "He is about 24 years old, of outstanding stature, with fine intelligence and tenacious memory, ambitious, thirsty for fame, courageous and brave, despising danger, very incendiary, broad-minded, prone to negotiation, but at the same time subjected to mood swing" "78. Together with Carmelites, the Impostor sent his embassy headed by Prince I.P. Romanovsky to shah Abbas to propose him joint military action against Turkey. It was stated in the order to the ambassador: "Впред великий государь... турскому за его неправды, а шевкалу за его измену терпети не учнет, пошлет на них многую рать свою и велит кумыцких людей до основания разорити и городы во всех

${ }^{76}$ Ambassade en Turquie Jean de Gontaut Biron, baron de Salignac (1605-1610). Paris, 1887. Р. 56; Флоря Б.Н. Османская империя, Крым и страны Восточной Европы в конце XVI - начале XVII в. // Османская империя и страны Центральной, Восточной и ЮгоВосточной Европы в XVII в. М., 1998. Ч. 1. С. 55.

77 Ambassade en Turquie Jean de Gontaut Biron, baron de Salignac (1605-1610). Paris, 1887. P. 56.

${ }^{78}$ Bertold-Ignace de Sainte-Anne. Reverend Pére. Histoire de L'Etablissement de la Misson de Perse par les Péres Carmes-Dechausses (e l'année 1604-1612) / Bruxelle, 1886. P. 131; A Chronicle of the Carmelites in Persia Papal Mission of the XVII-th and XVIII-th Centuries. London, 1939. Р. 110-111; Тюменцев И.О., Свиридонова В.П. Описание путешествия монахов по Волге в 1606-1607 годах (главы из “Хроники кармелитов”) // Стрежень: научный ежегодник. Волгоград, 2000. Вып. 2. С. 171. 
украинских местах поставити" (From now forth, the great emperor ... will not tolerate the Turkish tsar for his wrong actions, and Shevkal for his betrayal, will send his warriors to them, and order to diddle the Kumyk people and put cities in all Ukrainian territories) ${ }^{79}$. This embassy was sent just a few days before the murder of False Dmitry I, so on the way in the documents the name of Tsar Dmitry Ivanovich was wiped out and changed by the name of the Tsar Vasily Ivanovich Shuysky.

In fact, the relations with Persia and shah Abbas could provide the only real military ally to the Impostor in his anti-Turkish plans, since Persia had been at war with the Porte since 1604, and during the reign of tsar Dmitry Ivanovich, the shah was well on way in Turkish territory.

The shah, like the tsar, demonstrated incredible activity and international initiative: he sent embassies to the emperor, the kings of Spain, France, Poland, England, Scotland, the Doge of Venice. Like False Dmitry I, Abbas proposed a specific war plan: Western troops would attack the Bosphorus from the sea and Balkans from onshore, the Christian fleet would reach Syria and Palestine, and the shah himself would operate in the eastern Turkey, the Caucasus and the steppes, with the assistance of Moscow troops. The shah even offered a draft 18-point union agreement that no one had ever signed ${ }^{80}$. At the same time, Abbas also appealed to the Pontiffs Clement VIII and Paul $\mathrm{V}$, proposing to organize Western rulers and, in the event of the conquest of the Persian troops by Jerusalem, to transfer it to the Papal authority ${ }^{81}$. Both Popes, as in the case of False Dmitry I, tried to activate the shah himself for war. Sooner or later, the shah, like the tsar of Moscow, became disillusioned with his western allies. Only the two of them had real intentions and took real action for their realization, so their negotiations were to become fateful, and only the sudden murder of Tsar Dmitry Ivanovich eliminated this possibility.

Another ally of False Dmitry I in the anti-Turkish campaign cannot be missed, though his assistance was not systematical. We are talking about Zaporozhian Cossacks. Even in the time of Boris Godunov, Cossacks were receiving funding and weapons from the tsar, and the detachment of 3,700 Cossacks led by Ivan Solonin made several attacks on Turkish possessions of the western Black Sea, capturing 10 Turkish ships and burning Turkish cities Kyustendzhe and Mangolia ${ }^{82}$. at the approaches to Istanbul. The Impostor established links with Cossacks when he was still in Polish -Lithuanian

79 Тивадзе Т.Г. Иранский вопрос во внешней политике Московского государства в конце XVI и в начале XVII вв. Автореферат дисс. ... кандидата исторических наук. Тбилиси, 1966. С. 11-14; Магилина И.В. Россия и проект антиосманской лиги. С. 259-261.

${ }^{80}$ Магилина И.В. Россия и проект антиосманской лиги. С. 186-198.

${ }^{81}$ A Chronicle of the Carmelites in Persia. P. 103.

${ }^{82}$ Александренко В.Н. Материалы по Смутному времени. С. 291-292. 
Commonwealth. However, we have not yet been able to find any materials about the negotiations between Tsar Dmitry Ivanovich and Cossacks on joint actions on the southern front in the planned "holy war", though such a proposal Cossacks would not be able to refuse.

The ambition of False Dmitry I and the desire to induce the Polish king to ally led to the situation when the tsar officially informed his future father-inlaw Yuri Mniszech on January 29, 1606, about his first successes in the war against the Turks: "Part of our troops, we sent to Asia against Turks, fought against Turkish troops, with the help of God they were successful there, due to this some Turkish military leaders came to our town Terki, and retreating from the Turks took an oath for obedience to us" ${ }^{, 83}$. Mniszech supported his son-in-law's ambitions, Polish elites and king Sigismund III Vaza himself, who had received information about Tsar's Dmitry's intentions to fight against Sweden for the access to the Baltic Sea also demanded him to do so. On the other hand, it was the Polish ambassador to Crimea Florian Oleshko who in August 1605 informed the khan and the sultan of the Impostor's military plans. Mniszech also openly shared the tsar's military secrets: in early 1606 he reported that the war against Crimea and the Porte would begin at the same time soon ${ }^{84}$.

\section{CONCLUSIONS}

In fact, all preparations were finished, the first military clashes with the Turkish troops took place in the Caucasus. However, it all ended suddenly on the 17/27 of May 1606, False Dmitry I was killed in the Kremlin of Moscow by conspirators led by Vasyl Shuisky. At this time, the entire western world was waiting for the beginning of the "holy war" of Tsar Dmitry Ivanovich against the Porte. This was fueled also by the impostors' courtiers. In particular, the chief of the tsar's personal guards, Frenchman Jacob Margret, reported that Moscow kingdom "serves as a stronghold of Christianity" and "has more means to repulse the attacks of the Scythians and other Mohammedan peoples than many can imagine ${ }^{85}$. Jesuit Jan Velevitsky emphasized the personal ambitions of the Tsar Dmitry Ivanovich: he considered himself "the second Hercules, the glorious leader of all Christianity against the Turks" $"$. However, the "second Hercules" was killed

${ }^{83}$ СГГД. Ч. 2. С. 266.

${ }^{84}$ Виноградов А.В. Юрий Мнишек и дипломатические переговоры между Речью Посполитой и Русским государством в 80-x - 90-х годах XVI столетия // Смутное время: итоги и уроки. Иваново, 2012. С. 46-77.

${ }^{85}$ Устрялов Н.Г. Сказания современников. Ч. 1. С. 247.

${ }^{86}$ Рукопись Яна Велевицкого. С. 172. 
at the outset of the "holy war", never leading his army and not winning any significant victory.

\section{SUMMARY}

The article deals with the problem of the "holy war" and the plans of the anti-Turkish league, developed in the Moscow kingdom by the first tsarimpostor False Dmitry I. The theoretical considerations and diplomatic measures of the Impostor as well as the specifics of his actions are considered. It is shown that the ideas of Lzhedmitry continued to support the anti-Turkish ideology that prevailed in western Europe during the 16th century, however, these ideas were developed by him to liberate the religious shrines of the east and to increase his personal power and importance among European monarchs. Numerous facts of the real preparation of the Russian army for military actions in the east were provided, which were started but not completed because of the murder of the False Dmitry I.

\section{REFERENCES}

1. Государственный исторический музей. Отдел письменних источников (Москва). Ф. 484, д. 6.

2. Российская национальная библиотека. Отдел рукописей (СанктПетербург). Ф. 328, д. 91.

3. Российская национальная библиотека. Отдел рукописей (СанктПетербург). Ф. 464, д. 5.

4. Российский государственный архив древних актов (Москва). Ф. 52, оп. 2, д. 118.

5. Российский государственный архив древних актов (Москва). Ф. 78 , оп. 1 , д. 3.

6. Российский государственный архив древних актов (Москва). Ф .1192, оп. 2, д. 15, 16.

7. Российский государственный архив древних актов (Москва). Ф. 210, десятни, д. 6, 223.

8. Ambassade en Turquie Jean de Gontaut Biron, baron de Salignac (1605-1610). Paris, 1887.

9. Antonii Caetani nuntii epistulae et acta 1607-1611. Pragae, 1940.

10.Bertold-Ignace de Sainte-Anne. Reverend Pére. Histoire de L'Etablissement de la Misson de Perse par les Péres Carmes-Dechausses (e l'année 1604-1612) / Bruxelle, 1886.

11. A Chronicle of the Carmelites in Persia Papal Mission of the XVII-th and XVIII-th Centuries. London, 1939.

12. Hirschberg A. Dymitr Samozwaniec. Lwów, 1898. 
13. Агеева О.Г. Имперский статус России: к истории политического менталитета русского общества начала XVIII века // Царь и царство в русском общественном сознании. М., 1999.

14. Акты, относящиеся к истории Западной России, собранные и изданные Археографическою комиссиею / Ред. прот. И. Григорович. СПб., 1851. Т. 4: 1588-1632 гг.

15. Александренко В.Н. Материалы по Смутному времени на Руси XVII века // Старина и новизна. М., 1911. Кн. 14.

16. Буссов К. Московская хроника. 1584-1613 / Сост. А.И. Копанев, М.В. Кукушкина, ред. И.И. Смирнов. М., Л., 1961.

17. Виноградов А.В. Юрий Мнишек и дипломатические переговоры между Речью Посполитой и Русским государством в 80-х - 90-х годах XVI столетия // Смутное время: итоги и уроки. Иваново, 2012.

18. Дмитриевский А.А. Архиепископ Елассонский Арсений и мемуары его из русской истории: по рукописи трапезунтского Сумелийского монастыря. Киев, 1899.

19. Живов В.М., Успенский Б.А. Царь и Бог. Семиотические аспекты сакрализации монарха в России // Успенский Б.А. Избранные труды. М., 1994. T. 1.

20. Записки Станислава Немоевского (1606-1608 гг.) // Титов А.А. Рукописи славянские и русские, принадлежащие И.А.Вахрамееву. М., 1907. Вып. 6, приложения.

21. Ивонин Ю.Е. Имперская идея и проблема государственности в западной Европе XVI века // Вопросы истории. 1993. № 6.

22. История Димитрия царя московского и Марины Мнишек. Дневник Мартына Стадницкого / Публ. А.А. Титова // Русский архив. 1906. № 10.

23. Лаврентьев А.В. Для какой цели были отчеканены “золотые” Лжедмитрия I? // Вспомогательные исторические дисциплины. Т. 26. СПб., 1998.

24. Лисейцев Д.В. Русско-турецкие отношения в начале XVII века: от конфронтации к сближению // Отечественная история. 2002. № 5.

25. Магилина И.В. Россия и проект антиосманской лиги в конце XVI - начале XVII вв. Волгоград, 2012.

26. Максим Грек. Сочинение. Казань, 1860, ч. 2.

27. Маржерет Яков. Россия начала XVII в. Записки капитана Маржерета / Пебл. Ю.А. Лимонова. М., 1982.

28. Масса И. Краткое известие о Московии в начале XVII в. / Перев. А.А. Морозова, ред. Н. Рубинштейна. М., 1937.

29. Опись архива Посольского приказа 1626 года / Публ. В.И. Гальцов. М., 1977. 
30. Памятники древней русской письменности, относящиеся к Смутному времени // РИБ. Т. 13. СПб., 1909.

31. Петрей П. де Ерлезунда. История о великом княжестве Московском... М., 1867.

32. Полное собрание руських летописей. Т. 14. М., 1965.

33. Рукопись Яна Велевицкого // Записки гетмана Санислава Жолкевского о московской войне / Изд. П.А.Муханова. СПб., 1871. Приложения № 44.

34. Русская историческая библиотека. Т. 1. СПб., 1872.

35. Сборник материалов по русской истории начала XVII в. / Публ. И.М. Болдакова. СПб., 1896.

36. Сборник русского исторического общества. Т. 137. М., 1912.

37. Сказание Авраамия Палицына / Публ. О.А. Державиной, Е.В. Колосовой. М., Л., 1955.

38. Смутное время Московского государства (1604-1613 гг.). Вып. 1: Акты времени Лжедмитрия І-го (1603-1607 гг.) / Публ. Н.В. Рождественского // Чтения в обществе истории и древностей российских. 1918. Кн. 1.

39. Собрание государственных грамот и договоров, хранящихся в Государственной Комиссии иностранных дел Ч. 2. М., 1819.

40. Сперанский М.Н. Повести и сказания о взятии Царьграда турками (1453) в русской письменности XVI-XVII вв. // Труды отдела древнерусской литературы Института русской литературы (Пушкинского Дома) АН СССР. Т. 10. М., Л., 1954.

41. Тивадзе Т.Г. Иранский вопрос во внешней политике Московского государства в конце XVI и в начале XVII вв. Автореферат диссертации ... кандидата исторических наук. Тбилиси, 1966.

42. Тюменцев И.О., Свиридонова В.П. Описание путешествия монахов по Волге в 1606-1607 годах (главы из “Хроники кармелитов") // Стрежень: научный ежегодник. Волгоград, 2000. Вып. 2.

43. Ульяновский В.И. Смутное время. М., 2006.

44. Устрялов Н.Г. Сказания современников о Димитрии Самозванце. Ч. 1-2. СПб., 1859.

45. Флоря Б.Н. Османская империя, Крым и страны Восточной Европы в конце XVI-начале XVII в. // Османская империя и страны Центральной, Восточной и Юго-Восточной Европы в XVII в. М., 1998. Ч. 1 .

46. Юсим М.А. Макиавелли в России. Мораль и политика на протяжении пяти столетий. М., 1998. 
47. Юшков А. Акты XIII-XVII вв., представленные в Разрядный приказ представителями служилых фамилий после отмены местничества. Ч. 1. М., 1898.

Information about the author: Vasyl Ulianovskyi,

Doctor of History, Professor at the Department of Ancient and New History of Ukraine,

Kyiv National Taras Shevchenko University 60, Volodymyrska str., Kyiv, 01033, Ukraine ORCID: orcid.org/0000-0003-0536-8835 


\section{FLORENSKY AND HEIDEGGER: CONCENTRATION OF THINKING STRATEGIES}

\section{Stepan Vozniak}

\section{INTRODUCTION}

Philosophy is inherently harmonious and proportionate, and these are not just lofty epithets designed to give praise, but rather an essential indication of the content and direction of philosophy. The fundamental integrity of the world is the first condition for the emergence and implementation of thought as such. And it is no coincidence that the ancient Greek myth and logo as the first versions of the discourse about the world manifest themselves in the form of art - while their aesthetic characteristics and ontological nature coincide. Thinking and judgment go hand in hand with delight, chanting, praise.

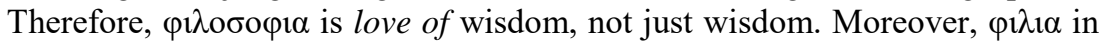
this case is what precedes, makes possible and gives rise to $\sigma 0 \varphi 1 \alpha$. Admiration, surprise and the ability to enjoy the mysterious beauty of the integrity of the world give rise to desire to conceive this integrity.

The fact of the existence of the history of thinking reveals historicity as one of the basic characteristics of thinking. Thinking is thinking only when it knows and remembers itself in its formation. Thus, the indicated rhythm, according to which thinking is consonant with being, is grasped as a memory and this is the first thing to be noted. Secondly, the presence of all kinds of concepts, systems, directions and traditions allows us to raise the question of the essence of thinking from different points, which makes understanding the problem voluminous, lively and meaningful. The history of philosophy makes it possible to compare initially disparate views - and in finding common ground to identify some ontological parameters of the desired problem - those that cannot be seen from a one-dimensional position.

One of the characteristic features of the modern world is the mixing of various traditions, while it is important to note that quite often this is not an eclectic mixture, but the inner kinship of various traditions. This text is an attempt to hear in the ideas of Martin Heidegger and Pavel Florensky a certain consonance with respect to memory as a gathering foundation and creative content of thinking. Within the framework of the problem of thinking, both philosophers are extremely interesting in that, as thinkers belonging to the twentieth century, they refer us to two traditions fundamental to European culture and philosophy: Martin Heidegger - to the event of ancient Greek thought, Pavel Florensky - to the event of Christian revelation. At the same 
time, the way of organizing their thoughts causes directly opposite characteristics - from admiration and pointing to radical novelty to recognizing their thoughts in such a way that violates the logical harmony and adequacy $^{1}$.

\section{Memory as the gathering foundation of thinking in Heidegger's concept}

When addressing the problems of thinking in Heidegger's philosophy, one should constantly not lose sight of two points. Firstly, Heidegger makes an ontological distinction between calculus thinking, characteristic of science and directed towards the essence, and substantive thinking, directed towards being. Secondly, one should not look for the essence of thinking in the ways of anthropology: thinking is not a certain property of a person, it does not belong to him at all - a person is able to enter into it.

The memory is most articulated problematized in the lecture course of 1951-1952, "What is called thinking?". But before turning to this text, I would like to draw attention to the most famous work of the philosopher "Being and Time". In the text of "Being and Time" there is no reflexive explication of the relationship between memory and thinking. But this indicates on the necessity to take into account the initial focus thoughts on time as a way of being Dasein: time is the only way of existential going out of the Dasein to its own existence. In this formulation of the question, the memory problem is invisibly present - both in terms of understanding the temporality of both the universal historicity of being, and in terms of the "personality" - existential self-determination of Dasein as subjectivity in its being through time. When referring to existential analytics of Dasein, memory could be considered as one of the defining existentials along with fear, care, determination, being-to-death, guilt, conscience. But the memory is not an existential in the same sense that and the above-mentioned fear, caring, conscience, guilt, etc. The fact is that in this case we call existentials the points of the most intense experience of a person meeting as a kind of essence with being. Memory is not an experience; in the case of understanding time as the only way in which being has been given, memory is rather the subjective basis of this given. In other words, in "Being and Time", memory is not that of time, it is how Dasein times itself, intentionally "tuning in" to existentials. In some sense, here you can hear an echo of the psychological understanding of memory as a property of consciousness to combine different temporal

\footnotetext{
${ }^{1}$ Гальцева Р. А. Мысль как воля и представление (Утопия и идеология в философском сознании П. А. Флоренского). П.А. Флоренский: pro et contra / Сост., вступ. ст., примеч. и библиогр. К. Г. Исупов. СПб.: РХГИ, 1996. С. 573-579, 597.
} 
modes in one relevant representation. Thus, the memory in "Being and time" can be defined as some existential schematics of temporality.

In the lecture course "What is called thinking?" The understanding of memory is rather explicit. It's logically to expect that the name is preceded by a logical-methodological study of the nature of thought, which creates a new conceptual system or even a new discursive definition of what is thought. But the main leitmotif seen in this text is completely different. This is the constant escape of the being of thinking from man. Something is calling us to think, but it can only be something that has not been thought: "Most thought provoking in our thought - provoking time is that we are still not thinking"2. And the point is not only and not so much that we have not yet found the true object to be thought, or have not learned to think correctly. The case in fact, that is, that truly requires understanding, constantly slipping away from our thinking : "We Said: man to still does not think, and this because what must be thought about turns away from him; by no means only because man does not sufficiently reach out and turn to what is to be thought" ${ }^{\text {. }}$. Why is slipping away? What is missing - visual acuity, depth of knowledge, or physiological capabilities? Nothing of the kind, turns away, pulls away, slips away that which is given for thought. Consequently, we are not able to grasp, pull, turn to ourselves this given - we do not own and do not control thinking.

A person falls into thinking; this is some initial situation into which he is thrown, and the conditions of this situation are by no means dictated by the person himself. Without a doubt, thinking is a human matter, and the most important thing, but we in no way control the way of thinking and being that is given to us. The only possible way of interacting with essence and being for a person is precisely thinking, but it does not grow out of a person, but out of being, from his way of organizing. We are not able to change the laws of logic since these laws stem from the way the universe is created, we are not able to change the temporal way of our being as well. We can only prevent it before the due date. It is not possession of thinking in principle, and perhaps it is the greatest gift to man - because it is through this not possession that we are given the opportunity to transgress, to walk, to extirpate into thinking as the Other to ourselves, thereby filling the original ontological for us with meaning that, again, it is not created by us, but is seen in being.

Does this mean that we are not able to think at all? In no way. Because it is not we own thinking, but thinking owns us: Heidegger emphasizes reciprocity movement - " $\ldots$ we truly incline only toward something that in turn inclines toward us, toward our essential being, by appealing to our essential being as

\footnotetext{
${ }^{2}$ Heidegger M. What is called thinking? Ed. J. Glenn Gray. Of Harper Perennial, 1976. P. 6.

${ }^{3}$ Heidegger M. What is called thinking? Ed. J. Glenn Gray. Of Harper Perennial, 1976. P. 8.
} 
the keeper who holds us in our essential being. What keeps us in our essential nature holds us only so long, however, as we for our part keep holding on to what holds us. And we keep holding on to it by not letting it out of our memory. Memory is the gathering of thought. Thought of what? Thought of what holds us, in that we give it thought precisely because It remains what must be thought about" . Memory is that which holds us in our being, in what we are. Preservation of integrity assumes that this integrity already existed from the beginning, and in the loss of it, is assembled again. Consequently, memory is also the gathering, unification and preservation of our essence in the literal sense of "safe and sound".

So, according to Heidegger, what do we keep in mind? First of all, ourselves, in every sense, starting with the psychological and ending with the ontological. We preserve ourselves as subjectivity, atomic in terms of inseparability, whole unity, understood as a person - and as a result of this, we preserve ourselves as a human race, literally "remember who we are". But we also store what is given for thought - in this way we store the being in its being. In other words, we keep the world in a memorable preservation. And mindfulness in this case is thought of as a force, a connecting thought, thinkers and conceivable in integrity.

That is why oblivion of being causes fear: it turns out that oblivion is termination from storage, abandonment of the stored to its fate. And if the main subject of the mindset from storage is a holistic connection of thinking and being, then it turns out that in communication this connection is lost.

It was previously mentioned that Heidegger thinks that this is thought to be elusive, turning away from us. Such a definition contains a very significant indication: it is only through slipping away, hiding the conceivable from us that we are able to realize, feel its ontological significance and materiality in order to preserve ourselves and the world. The same can be said about memory as a preserving thoughtfulness of thinking: in oblivion, in the loss of this repository, we comprehend its necessity and fundamentality.

What do we forget in oblivion of being? At the individual level, oblivion, forgetting oneself is always the loss of some personal integrity. We are what we are only when we remember ourselves - that is, we realize what exactly forms the center of our personality. Forgetting inevitably means some decay, the inferiority of our wholeness. Very clearly evidenced by the various types of mental disorders, which are ontological level and are characterized by oblivion. For example, the partial loss of some of the conscious perceptions and guidelines again leads to partial disorders, syndromes and pathologies. Amnesia as a complete and absolute forgetting of all persistent and significant

\footnotetext{
${ }^{4}$ Heidegger M. What is called thinking? Ed. J. Glenn Gray. Harper Perennial, 1976. P. 3-4.
} 
ideas is an irreversible disintegration of the personality, strictly speaking death, although not physiological. Thus, memory is understood not only as a separate ability of the psyche, but as the force that holds in agreement, awareness and integrity all the diverse forces, impulses and aspirations of consciousness.

And what about the oblivion of being at the universal historical level? What is lost in this case? First of all, the unity and continuity of the transfer of historical experience. Metaphorically speaking, we are losing our "roots" in the oblivion of being. Both historical and worldview. Going back to the roots is a very important intonation of Heidegger's philosophy. Any soil cultivation - both personally determined (as in the case of Heidegger's views), and socio-historical (the general attitude that took place in Germany between the two world wars) - is nothing more than an attempt to overcome the inevitably growing oblivion of being. But the most interesting and at the same time tragic is that this attempt doomed to failure in advance. This is because, with the loss of memory, understood as the oblivion of being, we forget not only our historical and temporal nature, but also our ontologically timeless essence. This is very clearly seen in the example of worldview crises characteristic of the modern socio-historical situation. Any loud-sounding (and therefore, according to Heidegger, inauthentic) calls to recall one's historical, temporal meaning - back to soil, to the authentic historical spirit of our community, to blood, to national or ethnic foundations - inevitably leads to the fact that we no longer define our own being, but those meanings determine $u s$, and it is precisely these fateful entities (blood, elements, spirit, nation, ethnos, party) which are engaged in this, whose historical guises have already shown themselves to be something monstrous. In an effort to regain lost memory, we surrender ourselves to the "spirit of the times", the "harsh demands of our time", often even simply to "the realities of life", or vice versa, we strive back to "historical memory" or fight to restore "historical truth and just rain", without thinking who and what will dictate to us in this blind, thoughtless, thoughtless fidelity and struggle. Memory preserves our being not only in history, in temporality, which reveals our being to us. It also protects a person's ability to resist his time and his own integration, subordination to the existing and dominant being. Returning to the source, the memory keeps what is conceivable for thinking. Memory is the guardian of the limit of being and non-being, protecting a human being from falling into a complete absence of thought.

Let us pay attention to the symphonic sound of thought and being. Memory as rhythm, harmony-forming force - preserves the symphony of the sound of thought, existing and sounding-about. For the loss of being, it always brings disunity, harmony, dissonance, since the binding bases of symphony 
are lost. Symphony is being replaced by cacophony - especially vividly, familiarly and vividly, again, this is illustrated by the crisis periods of the existence of any socio-historical formation. In yet another such oblivion, the field of thinking explodes in a cacophonic, disordered, and painful abundance of all kinds of false prophets, pseudoscience, charlatan religious practices, false ideological systems, and political ideologies. Instead of sounding-aboutbeing, a thought begins to scream about it in a bad voice. Simply put, in such periods "uniform craziness" starts (you can add - not only "uniform", but also "essential"): demention, distortion, dispersal of what must remain in the assembled unity. The oblivion of being, the loss of a saving and gathering memory inevitably leads to the loss of reason and thought, and now truly, "a dream of reason gives birth to monsters". Memory is the guardian of what is the edge of man, and man should not stand up for this edge.

Is, according to Heidegger, oblivion of being inevitable, or is it just some local distortion, the descent from the true path, which might not have been? Unfortunately, not. We still do not think, not because we are not addressing the given for thought enough - it draws itself away, eludes us. Repeatedly addressed Heidegger's philosophy sounded accusations of gloomy-mock tragedy and deliberate, excessive dramatization of the fate and place of man in life. Indeed, according to Heidegger, a human being is determined by the fact that it is burdened by its own being and constantly strives from it into oblivion, in the loss of memory. Actually, when we say that the essence of thinking does not belong to us, that we do not own it, we affirm that we can think only from a lack, from a lumen, from our human nothingness. This is the flip side of the comprehensive harmony of thought and being - they are identical and correlated in their essence, but they are not an indistinguishable continuity. The reverse side of any inseparable unity is its lack of fusion, and the thinking that falls upon us as a gift of our being thrown into being is thinking from a gap, from a split human being (here it is impossible not to recall the Hegelian "unfortunate consciousness").

Summing up what was said about Heidegger's understanding of the relationship between memory and thinking, we should return to the text of the lecture course "What is called thinking?". And note one more point that is significant for what follows. Thinking stores in memory what is given for thought. This for thought should be understood as a certain gift, descent only then thinking is actually thinking. The response of thinking to this gift of the conceivable is gratitude, therefore, thinking in its mindful being is gratitude. In the text, Martin Heidegger surprisingly strengthens and roots this turn of thought in the linguistic features of the German language: thinking (Denken), memory (Gedanc) and gratitude (Dankbarkeit) are the same root 
words. The saying in the language sounds in being, therefore, the kinship of thinking and memory is from the beginning.

It was previously indicated that the descent from memory, mind, loss of collected thinking unity and wholeness leads to distortion, distortion, separation of what is initially and essentially thought to be necessary to be collected. Keeping the direction of the indicated thought "in mind", we turn to the consideration of the understanding of memory in the light of the ideas of Pavel Alexandrovich Florensky.

\section{Memory as the basis of eternal life in the concept of Florensky}

Pavel Florensky is a Christian thinker, Orthodox priest, religious philosopher, and the essential center of his ideas is Christian revelation. An amazing combination of quiet, focused depth of peering with liveliness and richness of the sounding discourse is striking, which immediately catches your eye when accessing its texts. In general, religious philosophy, thinking as if "inside" Christian tradition, has a very important advantage: in it the unfolding thought is initially, originally, a priori rooted in being, from the very beginning of its development it is permeated with the light of Divine wholeness and validity - and, most interestingly, such rootedness does not destroy the internal discursiveness, dynamism and reflexivity, the "philosophical" nature of thought. There is some initial remembrance, storage, saving of thought - and saving is something with which it brings itself into a humble agreement even before the start of its own movement. In this case, the service of philosophy to the truth of Christian revelation in accordance with theology is understood not as submission and infringement of philosophical "free thinking", but as a foundation that justifies and raises thought to unprecedented heights.

The central work of Pavel Florensky is his master's thesis, "The Pillar and Affirmation of Truth. The Experience of the Orthodox Theodicy in the Twelve Letters". For further research, the epigraph of the whole work is extremely important: these are the words of Gregory of Nyssa " ' $\eta \delta \varepsilon \gamma v 0 \sigma 1 \zeta$

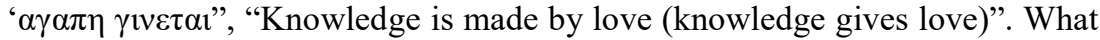
is important here? Cognition is made through love; cognition is transformed into love. Love acts both as what makes knowledge possible, and as its highest goal. In Christianity, there is some amazing ontological vigilance and sensitivity, able to catch, perceive, accept and conceive the coincidence and essential interpenetration of the absolute rationality of the Divine with its absolute love, which was already among the Greeks, but was strengthened in the Christian consciousness. No matter how we explain love, its original meaning, the "phenomenological framework" will be unchanged: the complete conversion of one to the other, the transfer of one's own essential center to something Other, which is understood as more substantial than 
myself. The aspect ratio loving and mind hides something very significant - is a reason itself only when is in harmony with the universal, universal (divine?). Consonant wholeness, or holistic agreement with the Absolute, is the only guarantee of the rationality of thought, since it is in such a loving agreement that the foundation is found. Reason without love is already a reason, which is understood not as wholeness, but as a self. It is love that overcomes the fear of losing one's self and allows the universal not to crush, wipe, obscure the individual, but on the contrary - to reveal the individual in its ontological uniqueness and significance. A self that is afraid of dissolving in the absolute is doomed to decay, dissolving in itself, since self-conversion is incapable of revealing its own essence. In the rational self-will and desire to explain everything only through oneself, one's own limits of individuality are lost, fogged and blurred, and then it is inevitably doomed to the loss of oneself.

Reason is always loving co-thought, harmony, co-being, co-sound. Therefore, the love of wisdom is reasonable. But wisdom without love is rational. Philosophy is therefore the love of wisdom, because it can overcome the pride of possessing wisdom. The universal is conceived of as holistic, intact by violent separation, tearing into separate individuals. The rational self is therefore the self because it wants to be itself. Its destiny is demons, who besiege the integrity of harmony and harmony with the universal and Divine: in the literal sense, "aimlessness" and "godlessness", which Florensky recognizes as sin.

And it is on the way that Florensky reveals the true nature of sin that we gain his understanding of the essence of memory. Here we should recall two points that have already sounded above. Firstly, this is an indication that the loss of mind, loss of sonority, memory and integrity is a distortion, perversion of the originally intact, preserved. Secondly, we must remember that the thematic field of the work of Pavel Alexandrovich is the problem of theodicy. Therefore, the question gains strength and sounding how in the world created by the all-good and absolute Deity, the sinfulness, distortion, perversity indicated above - in other words, evil - can be present? Florensky speaks of two paths: one of them is the path to the Truth, but how can there be another path that does not resemble it, if the Truth is the source of all existence, and there is nothing outside the Truth? How is it possible to admit some NonTruth, some Falsehood? If God is Life and the Culprit of life, then Falsehood is Death and the source of death, i.e. destruction. God is Harmony and Order; and Lies are Disorder and Anarchy. God is Holiness; and Lies are Sinfulness. But how can there be sinfulness? The logic of us leads to the fact that, although there is sinfulness, it is non-existent ${ }^{5}$.

\footnotetext{
${ }^{5}$ Флоренский П. А. Столп и утверждение истины. (Том 1, часть 1. Том 1, часть 2). М.: Правда, 1990. С. 167-168.
} 
What kind of being is the sins of reality, which is "non-existent"? What is the status of lies and death if they are non-being? Is it possible to conceive them in their being if their being as such is not? Not to recall the same Parmenides, it is wise to beware us of his, long before ours, time: " $<\ldots>$ being because there are, and there is nothing there, I pray thee think it over. First I turn you away from this path of search $<\ldots>$ So I will not allow I to say or think: it is unthinkable, inexpressible There is, which is not"6. A caution is more than appropriate - a thought is only then able to hold on, to keep itself intact when it refrains from an empty place, non-being, and is directed at the existing, becoming a thought-about, and not a thought-aboutnothing. Calling non-being, calling it into thought, we thereby can lose the thought. The ancient Greeks very vividly, albeit non-reflexively, felt the whole horror of the empty, evil infinity of non-being.

Nevertheless, there is sin. Moreover, it is so close to us that sometimes seems that there is nothing but him. It is so powerful in this world that he obscures its own light of True Being. How can non-being condone Being? What is the power of Lies, which is sin? It is that she impersonates the Truth. Sinfulness is a non-existence, deceitfully pretending to be true and justified. Sin is a fake, a deceit, a simulation of what really exists. What does deception do, does it create something essentially and ontologically new, belonging to being? No, there is no increase in being in sinful deception - but the really existing one undergoes distortion, distortion, perversion, what is created in Hegelian and Marxist philosophy, we call the transformed form of reality, which is non-substantial, but replaces the true form.

Here is the power and power of sin, since it is much easier to pervert and destroy the whole and intact than to create or restore, repair the wholeness. What is the destruction of the whole leading to? To its disintegration into parts, to plurality, which does not have some ontological unity. When we say that a certain thing is broken, damaged, we mean that some of its structural elements cease to functionally interact with each other, violate the integrity of the thing, which should be greater than the sum of its elements. Sin decomposes the whole into a plural, fragmented, but at the same time diverse variety of different variants of distortions of the real. Therefore, in that reality, which is our nearest life world, in this world evil acquires such a colossal, colorful and often enticing abundance of forms. Therefore, "his name is the legion". Demons always there are lots of, but they are always precipitated by one and the same fortress.

But is it possible that just the communication of the truly holistic to the multiply false can create, create something fundamentally new? No way.

\footnotetext{
${ }^{6}$ Фрагменты ранних греческих философов. Ч. 1. М.: Наука, 1989. С. 296-297.
} 
Why? Because any single form, being a product of that very sinful decay, does not strive for the integrity of something more than it, but only for itself. The sinfulness of individuality is in self-will. This is precisely the aforementioned self, desiring self-affirmation, volitioning only and exclusively itself. And in this self-will, self-affirmation, the main weakness of any evil and any sin is: "Desiring only himself, in his "here" and "now", the evil self-affirmation is inhospitablely locked away from everything that is not it; but, striving for a self-deity, it doesn't even remain similar to itself and crumbles and decomposes and crumbles in the internal struggle" 7 .

Ontologically, sin is a deception, a falsification of being. What is $\sin$ anthropologically? What is sin that has taken possession of man, his soul? Pavel Florensky defines it this way: "Sin is the moment of discord, disintegration and collapse of spiritual life. The soul loses its substantial unity, loses consciousness of its creative nature, is lost in the chaotic whirlwind of its own states, ceasing to be their substance. I choke in the "mental flood" of passions" ${ }^{\text {. }}$. And here is already a clear harmonious, symphonic consonance with the idea of Heidegger: in the oblivion of being, we forget ourselves, because with the loss of memory, that which stores us in our essence is lost, destroyed.

But what, following Christian tradition, keeps us and what is lost in a sinful fall? First of all, what is holding us in a single, inseparable integrity is lost. Where is the hidden center of our existence? In the Other to us, in the Divine. What can connect us with the Other, understood as the Divine? Love: "Without love - and love needs above all the love of God - the personality disintegrates in the granularity of the psychological elements and moments. The love of God is the connection of personality" ${ }^{\prime \prime}$. Love still presents itself as the power of binding. That is why thought is capable of moving from one to another, from the individual to the universal and from the general to the one, which connects these "one", "another", "general", "unit" with some universal connection. Here again sounds loving knowledge, philosophy. And what, then, is sin for reason? How does he harm him? The answer to this question is also found in Pavel Florensky: "Sin is that which deprives the possibility of justification and, therefore, explanatio, ie rationality. In the pursuit of sinful rationalism, consciousness loses its intrinsic

${ }^{7}$ Флоренский П. А. Столп и утверждение истины. (Том 1, часть 1. Том 1, часть 2). М.: Правда, 1990. С. 171.

${ }^{8}$ Флоренский П. А. Столп и утверждение истины. (Том 1, часть 1. Том 1, часть 2). М.: Правда, 1990. С. 174.

${ }^{9}$ Флоренский П. А. Столп и утверждение истины. (Том 1, часть 1. Том 1, часть 2). М.: Правда, 1990. С. 174. 
rationality" 10 . The proud, self-conscious rationality of the love of wisdom turns into the lust of reason.

So philosophy, the destiny of which is to look out for the one and the essential in existential diversity, turns into an ideology, for which the main thing is to create from the essential a ready-made worldview recipe for "value hierarchies", "public orientations", "educational attitudes", which in essence do not serve to explain and understanding of reality, but to ensure the benefit of their own creators. Reason, which has fallen from universal foundation, imagines itself to be reason, always claims to know the last truth of being and, naturally, to how to attach this truth to one's needs.

Here is the second "chord" of the harmony of ideas of Florensky and Heidegger. And oblivion of being, and the fall into sinfulness - lead to the collapse, decay, decay of wholeness and rationality. But in place of the disintegrated mind, the "legion" number of demonic "speculations" always begins to bloom.

What can a man oppose to the overwhelming, all-conquering power of sinful discord and decay? At first, a close, all-round look, there is vanishingly little - chastity and humility. But what is chastity for a gaze refracted in the light of True Being? Let us turn again to the thought of Florensky, who draws attention to the integrity and unspoiled nature of a human being, which a person can lose and forget, but that God always remembers him, he mentions the ritual moment of the Orthodox memorial service - the proclamation of "eternal memory". Thus, we gain an understanding of the essence of memory by Florensky. Destination nost $\mathrm{s}$ wisdom held in the world seed of God's memory.

And here it is possible to hear the "third chord" of the harmony of thought of Florensky and Heidegger: memory does not belong to us, it, like thinking, is not our "property", "ability", it is that which is addressed to us as preserving us. And, immediately, the following "refrain": without giving up self-will, which is detachment (Heidegger!) And humble chastity (Florensky!). We fall into the oblivion of being, into the sinful decay of our self.

Earlier we have made a reservation of a principle need for confrontation, resistance time - to be able to preserve our being. Now this idea may sound in a new way: everything in this world is somehow, of course, temporarily, everything is subject to decay and decay. Corruption, decay and death are an inevitable element of the order of things in the world, just as sin and falsehood are inevitable from this world. The world's only one "specific kind of things",

${ }^{10}$ Флоренский П. А. Столп и утверждение истины. (Том 1, часть 1. Том 1, часть 2). М.: Правда, 1990. С. 179. 
contains in its nature, some temporary "vertical" to the Absolute, true being a man. But the timeless, "eternal" essence of man is not given to him immanently, but about five, it is not his property: To counter the corrupting power of time, you must turn to the Other, who keeps us in himself, remembers us: "God grants victory over Time $\left.<_{\ldots}.\right\rangle$ and everything can partake of Eternity. How? - mindful of him" $"$.

The idea of the essence of memory in its sound here grows to unprecedented harmony and inclusiveness: memory is the main ontological foundation and, at the same time, our goal of its presence. All our creative powers, all the best that is capable of being stored in a person, we only turn to one thing - to exist in the world, to cling to some essence, so as not to be swept away and all-consuming stream of time, leave a timeless trace in it, an echo of some higher being, to put it simply, to leave a memory on oneself. Florensky sounds this brilliantly: "Thus $<\ldots>$ and love, and marital fidelity, and parental love for offspring, and all higher activities - in short - all life is based on nothing more than desire, as a thirst for eternal memory" 12 .

Once again: not we - remember, but - addressed to us (absolute, being, Truth, God) remembers us. But, nevertheless, what is memory "for us", "inside us", how does it manifest itself from within thinking and consciousness? What is the psychological and epistemological dimension of Divine Eternal Memory? Heidegger defines memory as "collected thinking" . In the same "tonality" Florensky also understands memory: "Already its psychological definition, namely, as a natural ability to represent", despite its abstractness, notes its essential connection with thinking processes in general. On the other hand, the theory of cognition, through the concept of transcendental apperception, together with all the latter entering acts of appergenation, reproduction and reconnaissance, makes memory the main cognitive function of the mind"13. Memory collects our diverse ideas into a whole. An amazing property of consciousness is to hold several representations, images, ideas, eidos at once in a single, here-and-nowmoment of time in reflexive awareness and comprehension. Moreover, all these eidos were as if carried away in a stream of time, instantly turning any present into the past - and in memory they seemed to be stopped, detained, retained, preserved.

${ }^{11}$ Флоренский П. А. Столп и утверждение истины. (Том 1, часть 1. Том 1, часть 2). М.: Правда, 1990. С. 193.

12 Флоренский П. А. Столп и утверждение истины. (Том 1, часть 1. Том 1, часть 2). М.: Правда, 1990. С. 197.

${ }^{13}$ Флоренский П. А. Столп и утверждение истины. (Том 1, часть 1. Том 1, часть 2). М.: Правда, 1990. С. 200. 
No magic is required to go beyond the bounds of consciousness, into the "astral", into the "rabbit hole" of the labyrinths of the subconscious, to which esoteric and pseudo-sci-fi "spiritual" practices are prone to invoke, bring the past or the distant into the "now", in the proximity of presence - we do this every moment of our life. Any simple logical operation involves mindfulness: moving from a subject to a predicate, we inevitably keep the subject in our memory, otherwise the predicate as if "sags" - because we already forgot the subject to which it belongs! When building a syllogism, the same thing happens: we do not create a syllogism, if, fixing the last premise, we forgot the first. Moreover, any act of sensory perception without compilation in memory is glued to individual reactions of our senses to various stimuli that are not correlated in a memorable unity.

\section{CONCLUSIONS}

Thus, memory collects and conditions all the various acts of our perception, thinking and cognition in their whole certainty. In this case, memory is the basis of any imagination, any imagination, any creativity: memory as an activity of the soul is mental creativity, while it is emphasized that our knowledge, precisely because of its rootedness in memory, initially does not refer to the temporary, but to the Eternal. Memory is a creative force capable of temporarily psychologically "corruptible" presentation converted into a mystical revelation through the retention and preservation, seen in time - forever. Simply put, memory - Communication link between a person of increments to the Eternal, and God, who is this eternity: "Therefore, indeed, the memory - this is the idea of excellence, the very idea in its purest and fundamental importance" 14 . The main motive in harmony with the ideas of Heidegger and Florensky is that memory creates, equips, forms an internal order and preserves thinking. Understood in the broadest possible sense, thinking is always mindfulness, and vice versa. Thinking, as was said at the beginning, is always the thinking of being. We do not determine the beginning and way of thinking, we enter into it.

But thinking, being rooted in being, nevertheless, inevitably gives in to it, retreats, takes flight. Why? Yes, because the powerful, innumerable variety of things and the amazing universality of being, this being of the one immeasurably exceeds, prevails, dominates thinking. We are in no way given the beginning and end of being, its initial, main secrets, with all its mysterious power we are weighed, tormented, tormented - and yet doomed to be turned on it. Yes, thinking - is always thinking of being, called for it has always been

${ }^{14}$ Флоренский П. А. Столп и утверждение истины. (Том 1, часть 1. Том 1, часть 2). М.: Правда, 1990. С. 203. 
and will be "not-yet" because the existence of infinitely stronger and deeper than any thinking appeals to it. Thinking and being are identical - identical on proportionality, but not identical in their original power. Before the multiple unity of being, thought is doomed to collapse, decay, oblivion. And, trying to overcome this oblivion, trying to cross the gap between the absolute and the individual, a person truly torments himself, suffers, dooms himself to the misfortune of consciousness. The all-conquering force of time, through which being itself reveals itself to us, carries away thinking, tears it from the roots and drags it along - there, into decay, into decay, into oblivion. This is precisely how the non-classical philosophical tradition arises - in the desperate refusal of the mind to embrace those historical and temporary cataclysms that fall upon the mind. Thought literally "sinks" in the waves of the time of being. Retreat, running away, despair, powerlessness of thought this is the theme of the philosophy of existentialism, which sees the fate of thought in accepting and experiencing this despair. Thought, unable to grasp the unity, order and harmony of being, makes the necessary conclusion about its absurdity. That is why the existential and in Heidegger's philosophy is so dark and frightening - because the most intense experience falling on the shoulders of his weight being is far outside the "comfort zone" of human existence. Alas, the forgetfulness of being, sin, evil, decay, collapse are not substantial, they do not have their own nature, but they are an inevitable, inseparable way of our presence in the world, because they are where we run, burdened by our own essence.

And that is precisely why memory is not just a "fundamental property", a "determining principle" of thinking. It is the only chance of thinking to resist the inevitable decay in front of the face of being, given for the thought addressed to us. Memory is a connecting and saving shield of thinking, a barrier standing in the way of an all-consuming time of being. In remembering, in tense retention of memory, we gain the ability to stay in our standing-in front of being, to stay almost "on an equal footing", at least without retreating into oblivion.

We were looking for the basis of the consonance of thought with being. It is necessary to identify what is capable of rhythmizing and harmonizing thinking- about. Thought only then retains its essence when it is in harmony, in harmony, in proportion to the data for thought. That is - for thinking, some symmetry, equal rights, balance between the thinker and we are merged is necessary, otherwise, again, thought will fall apart into thoughtlessness under the exorbitant weight of the given for thought. Such a "fair" balance and proportionality is found in the memory. Strictly speaking, it is memory that can recreate, grow, and conceive of being. And he does this in any of our human deeds. 
For example, we need to play a certain melody on some musical instrument. That is, the melody already exists, it is written, it is already being. And the tool also belongs to the realm of being, it is created. What remains for us, what falls to us in this case? To begin with, we recall the harmonious sequence of the melody, that is, we acquire its categorical structure, form (tempo, rhythm, duration) and content (order and consecutive arrangement of sounds). But we still need to remember how the melody should be performed on this musical instrument. And we remember (we regain it!), What actions are necessary to extract a particular sound, we recall from the memory the technique required for performance. Next, we need to remember what the melody sounds like - what it was created for, what experience, event, thought, phenomenon it announces. That is, we recall the mood of the melody. Then all dynamic and empathic nuances of the performance are recalled - melismas, amplification or tone-down, sound intensity, in other words, the character of the melody is created by memory.

And it turns out that in the simple reproduction of a melody (perhaps simple and unpretentious!), Memory creates a new, previously unprecedented, region of existence, creatively reflecting and developing an existing one. And what is most surprising is that all the creative work of memory that we painted for so long takes place not as a chain of mental acts, but instantly, timelessly, often - at the moment of performing the melody itself, holding together a huge number of these acts.

The unifying, protective and creative power of memory also manifests itself to us in the process of obtaining a philosophical education, when you read the primary sources you have a feeling that you are not so much learning new things - how much you remember what was originally known to you. Thinking therefore not to produce chimeras, and thinks being, because it is not of Thinking from itself some chords and ties of reality, but sees them in it, picks, listens, remembers reality.

The contours of the universal interconnectedness of being emerge through a chaotic pile of things and phenomena when we are able to catch, hold and remember, hold in memory the rhythm and melody of the consciousness of thinking and being.

\section{SUMMARY}

The article compares M. Heidegger and P. Florensky's approaches to memory understanding. Despite the fundamental difference of philosophical traditions, the author formulates the moments in which these thinking strategies coincide. This coincidence is as follows: in both cases, memory serves as a universal, integral foundation not only for the human psyche - for the human being as a whole. Attention is drawn to the ability of memory to 
maintain humanity in its entirety. Such integrity is understood as allowing one to preserve man, both as an entity and as history. In such coincidences of various thinking strategies, the author sees the possibility of formulating universal judgments about essential philosophical problems, since here one can trace the existence of some universal ontological foundation. Therefore, the comparison of different philosophical paradigms, based on the criteria of universal ontological parameters of the subject, is considered constructive and necessary by the author.

\section{REFERENCES}

1. Гальцева Р.А. Мысль как воля и представление (Утопия и идеология в философском сознании П.А. Флоренского). П.А. Флоренский: pro et contra / Сост., вступ. ст., примеч. и библиогр. К.Г. Исупов. СПб.: РХГИ, 1996. С. 559-605.

2. Флоренский П.А. Столп и утверждение истины. (Том 1, часть 1. Том 1, часть 2). М.: Правда, 1990. 352 с.

3. Фрагменты ранних греческих философов. Ч. 1. М.: Наука, 1989. $576 \mathrm{c}$.

4. Heidegger M. What is called thinking? Ed. J. Glenn Gray. Harper Perennial, 1976. 272 p.

Information about the author: Stepan Vozniak,

Candidate of Sciences (Philosophy), Associate Professor at the Department of Philosophy, Sociology and Religious Studies, Faculty of Philosophy, Vasyl Stefanyk Precarpathian National University 57, V.Chornovola str., Ivano-Frankivsk, 76015, Ukraine ORCID: https://orcid.org/0000-0003-2268-5736 


\section{INSTITUTIONAL INTERACTION \\ AND POLITICAL CHOICE IN A TRANSITIONAL SOCIETY. WHAT ROLE FOR THE SOCIAL SCIENCES?}

\section{Liliya Yakovleva, Denys Yakovlev}

\section{INTRODUCTION}

In post-communist Ukraine, which is transiting from Soviet totalitarianism to democracy, the conflict between the new rules of the game and the old institutions is escalating (Matsiyevsky Y. $(2018)^{1}$, Stefes C. $(2006)^{2}$, Ghia N., Cenusa D., Minakov M. $\left.(2017)^{3}\right)$. The society needs changes. The Revolution of Dignity, as well as the results of the electoral campaigns of 2014 and 2019, shows the articulated powerful social intentions for the continuation of democratic transit and the creation of new rules and institutions.

"Ukraine has changed the political landscape: the vast majority of political actors publicly call themselves democrats, almost all political parties are placed under the democratic codes. Democratization involves looking for mechanisms of one of the main tasks solving: rational actions transformation of the individual and collective political actors to the collective rational action with the satisfaction of public interest" .

Instead, the post-Soviet institutions are resisting change. They are ready to throw the baby out with the bathwater to maintain power and ownership. Media manipulation, speculation on the subject of armed conflict, deprofessionalisation of government and ignoring social policy are all used to compromise democratic reforms. All this requires a study of institutional interaction through the lens of political choice theory. One of the factors that hinder this transit is the lack of a tradition of institutional interaction. Indeed, in the Soviet era there were no branches of power independent from the party leadership of the CPSU - legislative, executive, judicial, etc., and therefore their legal and public interaction.

${ }^{1}$ Matsiyevsky Y. (2018) Revolution without Regime Change: The Evidence from the PostEuromaidan Ukraine. Communist and Post-Communist Studies, vol. 51 no 4, pp. 349-359.

${ }^{2}$ Stefes C. H. (2006) Understanding Post-Soviet Transitions. London: Palgrave Macmillan.

${ }^{3}$ Ghia N., Cenusa D., Minakov M. (2017) Democracy and its Deficits: The Way of Georgia, Moldova and Ukraine towards Becoming European-Style Democracies. Center for European Policy Studies policy papers. Retrieved from: http://www.3dcftas.eu/publications/other/ democracy-and-its-deficitsway-georgia- moldova-and-ukraine-towards-becoming

${ }^{4}$ Yakovlev D. (2015) Democracy "On the March": Rethinking the Role of Propaganda and the "Party of Power" under Armed Threat. Proceedings of the Scope: science of politics - International Interdisciplinary Conference of Political Research (Bucharest, May 8-9, 2015), University of Bucharest 
In the search of an answer to the problem of Ukrainian ambivalence discussed by M. Riabchuk (1992, 2002, 2015) ${ }^{5}$ et al. (Walker E. W. (2014)) ${ }^{6}$, researchers have repeatedly addressed the issues of identity (Kuzio T. $(1996))^{7}$, linguistic diversity (Kulyk V. (2011) $)^{8}$, external challenges (Mitrokhin N. (2015) ${ }^{9}$, (Kuzio T.(2017) $)^{10}$.

It is time to look at the phenomenon of political choice and institutional interaction. The method of choice is the key to solving the problem of ambivalence, which allows avoiding two disadvantages of behaviour of the late Soviet and Ukrainian elites: 1) escape from choice (Yakovlev D. (2015) $)^{11}$ and 2) traps of "hybridity".

The article is devoted to the role of the social sciences in the choice of the optimal model of institutional interaction. The social sciences should help individuals make choices while collaborating with other people, institutions or organizations in politics and economics, education and culture. To accomplish this mission, we create models, offer dilemmas (alternatives) of choosing, study history, and predict the future, trying to assess the risks and consequences of one or another choice.

The existing inter-institutional interaction studies do not analyse the specificity of post-communist transit conditions (Young A. (2017)) $)^{12}$. The papers devoted to this transit and political choice increasingly underestimate the importance of institutional interaction (Clement J. $(2016)^{13}$. Our objective

\footnotetext{
${ }^{5}$ Riabchuk M. (1992) “Two Ukraines?”. East European Reporter, vol. 5, no. 4, pp. 18-22; Riabchuk M. (2002) Ukraine: One State, Two Countries. Transit Online. Retrieved from: http://www.eurozine.com/pdf/2002-09-16-riabchuk-en.pdf;Riabchuk M. (2015) “Two Ukraine's' Reconsidered" The End of Ukrainian Ambivalence? Studies in Ethnicity and Nationalism, vol. 15, no. 1, pp. 138-156.

${ }^{6}$ Walker E.W. (2014) "Ukraine: Divided Nation, Divided State. Eurasian Geopolitics. Retrieved from: http://eurasiangeopolitics.com/2014/03/14/ukraine-divided-nation-divided-state

${ }^{7}$ Kuzio T. (1996) "National Identity in Independent Ukraine: An Identity in Transition. Nationalism and Ethnic Politics, vol. 2 no. 4, pp. 582-608.

${ }^{8}$ Kulyk V. (2011) "Language Identity, Linguistic Diversity, and Political Cleavages: Evidence from Ukraine." Nations and Nationalism, vol. 17 no. 3, pp. 627-648.

${ }_{9}$ Mitrokhin N. (2015) "Infiltration, Instruction, Invasion: Russia's War in the Donbass". Journal of Soviet and Post-Soviet Politics and Society, vol. 1, no. 1, pp. 219-249

${ }^{10}$ Kuzio T. (2017) Putin's war against Ukraine. Revolution, nationalism, and Crime. Toronto: Association with the Chair of Ukrainian Studies, University of Toronto

11 Yakovlev D. (2015) Political choice of Ukraine: alternatives to the Grand Duke and restriction of the last secretary general. Proceedings of the Social and political configurations of Modernity: Political Power in Ukraine and in the World: Materials of the 4th International Scientific and Practical Conference (Ukraine Kyiv, June 3-4, 2015) (eds G. Derlugyan, A.A. Melnichenko, P.V. Kutuev, A. A. Migalush), Kyiv: Talcom, pp. 39-41.

12 Young A. (2017) Democratic Dialogue and the Constitution. New York: Oxford University Press

${ }^{13}$ Clement J. (2016). Electoral rule choice in transitional economies. Journal of Institutional Economics, vol. 12, no. 4, pp. 895-919.
} 
in this article is as follows. Firstly, to identify the dilemmas of political choice research in the conditions of post-communist transit. Only the social sciences can offer an interdisciplinary approach to post-communist transit that takes into account the particularities of individual choice in politics (electoral choice) and religion, economics (profit maximization) and culture. Secondly, to outline the contours of the theory of choice of institutional interaction in Ukraine (between the institutions of "peace" and "war", authoritarian and democratic, public and shadow institutions, etc.). The conclusions identify the need for a multidisciplinary approach to the problem of choosing the optimal model of institutional interaction and the rejection of a "hybrid" in favour of a dialectical "synthesis".

\section{The "Homo eligit" Model and the Dilemmas of Political Choice Research}

The process of political and economic transit of Ukraine to democracy and market economy takes place in the conditions of building the information society, multipolarity of international relations under the influence of many factors. It becomes evident that none of the global players (as far as Ukraine's interests are concerned, i.e. the EU, the US, the Russian Federation) is able to impose a transit model on Ukrainian society. In this sense, the age of empires that were capable of keeping large territories under total control is over. It is obvious that some empires, like repressive and big multinational states, are trying to revive; so far, such attempts have failed (Motyl A. J. (2001)) ${ }^{14}$. In Ukraine, which is at the crossroads of global interests, information flows, different values, different policies, there is a chaos of voices, thoughts and meanings.

In fact, as at the beginning of the twentieth century, we have implemented the "Huliaipole" model, however, in symbolic and informational terms. What should be done to turn the 21 st century into a ravaged century for Ukraine? (Conquest R. (2001)) ${ }^{15}$. Almost the only way to make decisions in such circumstances is to make daily rational choices. If the Ukrainian homo politicus wants to be successful in the plural world, it has to become homo eligit - the person of choice.

The mission of the social sciences is to determine "What?", "Why?" and "How?" individuals in the Ukrainian society, which has been deprived of the possibility of choice in various "empires" for centuries, elect.

\footnotetext{
${ }^{14}$ Motyl A. J. (2001). Imperial ends: the decay, collapse, and revival of empires. New York: Columbia University Press

${ }^{15}$ Conquest R. (2001). Reflections on a ravaged century. New York-London: WW Norton \& Company
} 
It is preferable to start with the historical experience of the collapse of the Soviet empire, the crisis of the project of homo soveticus (the "Soviet man"). Particular emphasis should be placed on the importance of overcoming indoctrination in secondary and higher education, the source of which is the ideologization of all social interactions in the USSR. Indoctrination not only hinders critical thinking (which is undoubtedly one of the competences of homo eligit) and is a system of imposing a certain ideology but also actualizes the problems of collective memory, identity and modes of truth. Indoctrination “... involves exposing the ideologization of education, the dangers of recapitalizing choice, and deconstructing the canon through demonstrating historical alternatives ... of choice" (Kroytor A., Yakovlev D., Aleksentseva-Timchenko K. (2019)) ${ }^{16}$. Indoctrination, according to J. Jay, means, first of all, the following: 1) the source of information is the state; 2 ) the absence of alternatives regarding the government position of views and versions of events (Jay J. (2019)) $)^{17}$.

Overcoming indoctrination is the first step to making a rational choice for an individual. The second step is to critically rethink the Soviet experience. The awareness of the "escape from choice" that characterized the actions of the Soviet elites during the rule of L. Brezhnev (the era of "stagnation") and M. Gorbachev (the era of half-hearted reforms of "perestroika" and "glasnost") is necessary. The political situation has changed globally. It is becoming increasingly apparent that the efforts to mitigate the existing contradictions through the formation of the "pseudo-consensus" to which the Ukrainian elites got accustomed in the late 1980s did not save them in the early third decade of the 21 st century. Creating ideological, political and economic "hybrids" is a mistake in terms of both politics and public policy. On the contrary, formulating real alternatives and deciding what is best for society is the only way forward. Naturally, one of the main dilemmas of choice "... is to solve the problem of choosing an optimal course of behaviour in the conditions of uncertainty: "To choose or not to choose?" An illustration of the first way "Choose!" is the choice of religion by Prince Vladimir. According to the chronicles, this figure not only chose the monotheistic religion (Christianity of the Byzantine rite) but also imposed his own dictatorial decision in a way that influenced the life of Europe for many

\footnotetext{
${ }^{16}$ Kroytor A., Yakovlev D., Aleksentseva-Timchenko K. (2019) 'Apostles' of indoctrination: ideological peculiarities of representation of religious choice in the secondary education (based on analysis of expert interviews) Ideology and Politics, no. 2 (13), pp. 127-146. Retrieved from: https://ideopol.org/wpcontent/uploads/2019/12/

${ }^{17}$ Jay J. (2019). Education or Indoctrination. Discerning the Difference. Free Book site. Retrieved from: https://islidedocs.com/document/education-or-indoctrination-discerning-thedifferencefree-book
} 
centuries. To illustrate the alternative "Not to choose!" it is worth mentioning the activity of the last USSR General Secretary M.Gorbachev. Despite the large-scale (as for the Communist leader) reforms, he failed to choose between the Soviet model and democracy. Instead, in order to combine them, he proposed a semi-reform project - "perestroika" (Yakovlev D.V. (2016)) ${ }^{18}$.

Thirdly, we need to be very careful about the recommendations of our Western partners and carefully choose the ones that are "suitable" for the Ukrainian situation. It is likely that modern developed countries have simply forgotten how they became consolidated democracies, and the way a market economy emerged and modernization began (De Soto, H. (2000) ${ }^{19}$. Thus, it is appropriate to throw a bridge to the topic of institutional interaction. At the stage of market relations, the start of modernization and competition, private ownership has become the most important institution, and the main task of the elites was not only the fight against corruption or the emphasis on cultural or national differences but also the legalization and legal protection of private property (Gilbert, A. (2002)) $)^{20}$.

Last but not least, political choice needs to take into account the peculiarities of post-communist societies and the overcoming of pathologies that have emerged in the process of transition. Diagnosing them is a direct task of the social sciences. E. Golovakha singles out the following social pathologies of post-communist societies: the ambivalence of political consciousness, the combination of conformism and nihilism in the attitudes of individuals to reality, deprofessionalization, erosion of the criteria of status and prestige in social interaction, deactualization of values (Golovakha E., Panina N., Vorona V. (2000) $)^{21}$.

They cause the consequences in the attitudes of citizens to politics, namely - the trust in populist manipulations, paternalism, and the tendency to moralising.

Having identified the role of the social sciences in formulating sound alternatives to rational choice and overcoming indoctrination, critical rethinking of external recommendations, and diagnosing social pathologies, we should turn directly to the analysis of a "situation of choice". Imagining

${ }^{18}$ Yakovlev D.V. (2016) Dylemy vyboru. [Dilemmas of choice]. Young scientist, vol. 7, no. 34, pp. 503-508. Retrieved from: http://molodyvcheny.in.ua/fi les/journal/2016/7/120.pdf

${ }^{19}$ De Soto H. (2000). The mystery of capital: Why capitalism triumphs in the West and fails everywhere else. Bantam Press

${ }^{20}$ Gilbert A. (2002) On the mystery of capital and myths of Hernando de Soto: what difference does the legal title make? International Development Planning Review, № 24 (1), pp. $1-19$.

${ }^{21}$ Golovakha E., Panina N., Vorona V. (Eds) (2000) Sociology in Ukraine. Selected Works Published During 90-th. Kiev: Institute of Sociology 
and presenting individual behaviour as a transition from one choice (a "situation of choice") to another one is difficult intellectual work that requires the identification of alternatives and their "weighing", evaluation according to many factors. Rather, the interpretation of a political decision as a consequence of choice enables the social sciences to explain its causes and consequences. As G. Hodgson notes, “... a principal goal of any science is explanation. Explanation causes suggestion of cause and effect relationships. Without a presumption of causality, there can be no convincing scientific explanation for any phenomenon" 22 .

It is much more difficult to determine the political course of the country through the lens of an election series with one of many complex and ambiguous alternatives. We use the artistic image of a "Knight at the Crossroads", known since childhood. Is it possible to use the metaphor of a "Country at the Crossroads"? Thus, taking into account the following factors: "geographical location between regional and global centres of influence, domestic and foreign policy challenges, constitutional reversals, economic situation (most notably - a hybrid combination of private and state ownership), etc. In fact, in every social area, the situation of choice can be observed... political choice is not limited to alternatives to the return to the Soviet "bright" past or the desire for the democratic future" ${ }^{23}$. Reflection on the democratization of institutional interaction based on an analysis of the "situation of choice" is complicated by the process of demodernization in the post-Soviet space $^{24}$.

In the process of modernization that Western democracies underwent, the choice has become a routine. The rules of political and economic interaction have become established and recognized. With modernization, the daily choice of an individual, as well as the choice of the political course of a country, is based on certain interests and values, norms and rules that have remained unchanged for decades. The modernization of society immensely facilitates the choice of an individual. After all, most important decisions have already been made, "great narratives" have been created and legitimized: "Modernization has created a world in which it seems that the "Great Choice" remained in history: the consumer chooses products in the supermarket every day, the viewer chooses television channels, and the bureaucrat, though he

\footnotetext{
${ }^{22}$ Hodgson G. (2001). How Economics Forgot History. London: Routledge.

${ }^{23}$ Yakovlev D.V. (2017) Ideja vyboru [The idea of choice ]. Proceedings of the Reghionaljna polityka : istorija, polityko-pravovi zasady, arkhitektura, urbanistyka: Tretja mizhnarnarodna naukovo-praktychna konferancija (Ukraine, Kyiv, November 22-23, 2017), Kyiv: Kyjiv. nac. un-t budivn. i arkhit-ry ta in, vol. 1, pp. 43-48.

${ }^{24}$ Rabkin Y., Minakov M. (eds.) (2018). Demodernization: A Future in the Past. Stuttgart: Verlag
} 
makes a crucial political choice every day, is opposed to political leaders who led European nations in the past. From heroic, dramatic or comedic act, the choice has become a routine affair" 25 .

On the other hand, in the process of demodernization, the destruction of habitual lifestyle and rethinking of values, interests and norms takes place (Individual and collective ones). It should be emphasized that in the process of demodernization the role of the social sciences is to rationalize the choice: to define its social framework, political conditions and alternatives.

The theory of political choice has "...formed a rather sceptical attitude to the theory of rational choice as it is presented in the model Homo ekonomicus. We tend to talk about choices based on the principle of bounded rationality. This allows taking a more balanced approach to understanding the principles of political choice: from electoral one to the choice of optimal constitutional and institutional policies. However, the main requirement of the idea of choice is alternativeness. The very logic of political choice in a democracy implies alternativeness: a political figure has to be chosen from among different candidates. Alternativeness means difference; in competitive elections, it is a competitive difference" 26 .

For instance, contemporary Ukrainian political politics has identified the following political choice dilemmas regarding institutional interaction: 1) Authoritarianism vs. Democracy; 2) Presidential vs. Parliamentary forms of government; 3) Proportional vs. Majority election models. Choosing the best institutional interaction model is impossible without addressing these global dilemmas. For more than twenty-nine years, Ukrainian political elites have been trying to make that choice, but have been limited to "hybrid" models: the parliamentary-presidential form of government, a mixed electoral system, democracy, and the remnants of Soviet authoritarianism. It is noticeable that a rational choice based on the consent of elites and society on these dilemmas should be constitutionally enshrined. Solving these dilemmas in favour of democracy, parliamentarism and the proportional electoral system has to be a prerequisite for effective institutional interaction: "Democratization involves seeking mechanisms for solving one of the main tasks: transforming rational

${ }^{25}$ Yakovlev D.V. (2015) Alea jacta est: vybir jak element socialjnoji vzajemodiji [Alea jacta est: choice as an element of modern interaction] Proceedings of the Priorytetni naprjamky rozvytku suspiljnykh nauk u 21 stolitti": materialy mizhnarodnoji naukovoji konferenciji (Ukraine, Kherson, February 27-28, 2015), Kherson: Gheljvetyka, pp. 155-159.

${ }^{26}$ Yakovlev D.V. (2017) Ideja vyboru [The idea of choice ]. Proceedings of the Reghionaljna polityka : istorija, polityko-pravovi zasady, arkhitektura, urbanistyka: Tretja mizhnarnarodna naukovo-praktychna konferancija (Ukraine, Kyiv, November 22-23, 2017), Kyiv: Kyjiv. nac. un-t budivn. i arkhit-ry ta in, vol. 1, pp. 43-48. 
actions of individual and collective political actors into a collective rational action to satisfy the public interest. Traditionally, the post-Soviet elite tries to avoid "either-or" choice, but Ukrainian political history knows many examples of when "confusion" has led to political crises, confrontation of branches of power and their irresponsibility ... In Ukraine, elections were conducted on proportional, majority and mixed bases. The main dilemma regarding the electoral model is the choice between a full-fledged representation and a structured parliament. According to the proportional system, the role and weight of political parties is increasing, which can gradually become an effective institution of political representation"27 The situation of choice is an element of the research program that provides an appropriate picture of the world. Researchers rely on the model "Homo eligit", and their further steps depend on the choice of one of the alternatives. As a research program in the social sciences to form an optimal model of institutional interaction, the following alternatives are offered: 1) Individualism vs. Collectivism; 2) Action vs. Structure; 3) Hierarchy vs. Network; 4) Stability Vs. Conflict; 5) Rationality Vs. Irrationality ${ }^{28}$.

The first dilemma is fundamental, and the most heated discussions are held around it. L. Udehn points out that "...there have been many names used to designate the two camps and their respective doctrines. In the twentieth century two (or three) names have been selected as the most common. The battle has been increasingly waged in terms of methodological individualism, and its transmutations, versus methodological collectivism and/or holism... I believe the first view is more correct. Anyone the least acquainted with the social sciences knows that it matters which view you adopt in this matter. Methodological collectivists and holists do tend to ask different questions and provide different answers than do methodological individualists. There are important differences also within the two camps, but this is another matter. I also find it hard and a little bit odd to believe that the best minds in the history of social thought should really have engaged, and with so much energy, in something which turns out to be a sham battle. Didn't they notice?"29.

${ }^{27}$ Yakovlev D.V. (2017) Ideja vyboru [The idea of choice ]. Proceedings of the Reghionaljna polityka : istorija, polityko-pravovi zasady, arkhitektura, urbanistyka: Tretja mizhnarnarodna naukovo-praktychna konferancija (Ukraine, Kyiv, November 22-23, 2017), Kyiv: Kyjiv. nac. un-t budivn. i arkhit-ry ta in, vol. 1, pp. 43-48.

${ }^{28}$ Yakovlev D.V. (2016) Parlament na rozdorizhzhi: Rada jak instytut politychnogho vyboru [Parliament at the Crossroads: The Council as an Institute of Political Choice] Proceedings of the Parlamentsjki chytannja : 6-ta shhorichn. mizhnar. konfer. (Ukraine, Kyiv, November 18-19, 2016), Kyiv: FOP Zhorin R. V., pp. 12-17.

${ }^{29}$ Udehn L. (2002). The Changing Face of Methodological Individualism. Annual Review of Sociology, no. 28, pp. 479-507. Retrieved from: www.jstor.org/stable/3069250. (accessed online January 26, 2020). 
The theory of choice has both advantages and limitations. Basic assumptions include ideas about rational behaviour of an individual (which is not always the case), attempts to maximize benefits (exceptions are also possible here), attention to opportunistic behaviour, rents, transaction costs, etc. When it comes to the political choice of the optimal model of institutional interaction, it is necessary to determine the essence of "public interest". Political activity should not be aimed at serving the selfish interest of an actor or institute, but at serving the public good. The implementation of the model of "Homo eligit" is impossible if we still believe in the invisible hand of the market. On the contrary, the political choice theory makes it clear that democratic reforms are possible only under the conditions of proper planning, creation of political, legal and economic conditions for the rational construction of institutional interaction.

The prime example is the formation of an optimal model of institutional interactions.

\section{The Combinatorics of Choice: the Role of the Social sciences in Optimizing Institutional Interactions}

Institutional interaction is studied in terms of law and constitutional theory (Young A. (2017)) $)^{30}$, economics (Šimić Banović, R. (2015)) $)^{31}$ and public policy (Raišienė A. , Bilan S., Smalskys V., Gečienė J. (2019)) $)^{32}$.

J. Mark Ramseyer convincingly explains the link between political choice and the work of institutions: "First - and most basically - in modern democracies, politicians must work to compete in electoral markets or they do not stay politicians. As a result, there's a market constraint to politics. Second, because of this constraint, when constituents don't much care about an issue, rational politicians will likely trade their vote on it for a vote on something their constituents do care about. There's simply no such thing as a free vote. Last, institutions decisively shape the way voter preferences get mapped onto legislation. Often, the institutional structure of the electoral market itself determines what becomes law" (Ramseyer J. M. (1995)) ${ }^{33}$.

30 Young A. (2017) Democratic Dialogue and the Constitution. New York: Oxford University Press

${ }^{31}$ Šimić Banović, R. (2015). Institutional Interaction in the Business Environment: Eastern European Versus Western European Countries. Zbornik Pravnog fakulteta u Zagrebu, vol. 65, no. 3-4, pp. 439-480.

${ }^{32}$ Raišienè A. , Bilan S., Smalskys V., Gečienè J. (2019). Emerging changes in attitudes to inter-institutional collaboration: the case of organizations providing social services in communities. Administratie si Management Public, no.33, pp. 34-56.

${ }_{33}$ Ramseyer J. M. (1995) Public Choice. Coase-Sandor Institute for Law \& Economics Working Paper, no. 34. Retrieved from: https://chicagounbound.uchicago.edu/cgi/ viewcontent.cgi?article $=1393 \&$ context=law_and_economics 
Based on the theory of choice theory, the social sciences can offer a solution to the problem of optimal combinatorics of institutional interaction. The consideration of individual institutions is erroneous. The experience of post-communist reforms has convincingly demonstrated that the problem lies not in the creation of individual institutions, but in ensuring their effective interaction. This approach requires interdisciplinary research. The success of institutional interaction is hindered not only by political but above all by social and cultural factors: "In Central and Eastern Europe, institutional design seems to be highly influenced by the complex legacy. It has now been widely accepted that "no size fits all" when implementing institutional reform. Transition experience confirms several factors as essential for institutional change: the existing belief system and its evolution, trust and culture. In postsocialist societies, the prevailing culture is considered to be the main cause of increased transaction costs of institutional restructuring" (Šimić Banović R. $(2015))^{34}$.

To achieve the success of reforms, we should find the courage to build institutional interaction, not only by mechanistic borrowing of institutions similar to the ones in the countries of consolidated democracy but also by creating our unique model.

For this purpose we will use the method of "philosophical combinatorics" (Eremenko A., Yakovlev D. (2019)) $)^{35}$ and the theory of political choice.

After the events of 2013 - 2014, political elites in Ukraine are constantly seeking the optimal balance of power, solving the dual problem of ensuring the country's defence and democratizing institutional interaction. The constant fluctuations of the political course hinder the solution of this problem (Bilaniuk L. (2017) $)^{36}$.

Society cannot keep up with responding adequately to the constitutional, institutional and socio-cultural reversals of the elites. This fact diminishes the level of solidarity, institutional support and legitimacy of the elites. Simultaneously, it has a negative impact on both the level of defence and the level of democratic reforms: "Ethno-linguistic and regional identity became quite politicized during the 2004 presidential election. From then until 2014,

${ }^{34}$ Šimić Banović R. (2015). Institutional Interaction in the Business Environment: Eastern European Versus Western European Countries. Zbornik Pravnog fakulteta u Zagrebu, vol. 65, no. 3-4, pp. 439-480.

${ }^{35}$ Eremenko A., Yakovlev D. (2019) "My dialektiku uchili ne po Gegelyu". Filosofiya v zerkale politicheskoy propagandy: popytka antropologicheskogo podkhoda ["We studied dialectics not according to Hegel". The philosophy in the mirror of political propaganda: an attempt to the anthropological approach] Current problems of philosophy and sociology, no. 24, pp. 10-23.

36 Bilaniuk L. (2016). Ideologies of Language in Wartime. Revolution and War in Contemporary Ukraine: The Challenge of Change. Boston: AST, pp. 139-160 
political parties often used the "language issue" and the regional division for their purposes of mobilizing the electorate. This short-sighted practice has reduced solidarity in Ukrainian society. In the spring of 2014, linguistic and ethno-cultural issues were used not only for political purposes but also to substantiate the idea of separating the south-eastern regions of Ukraine (the so-called "Novorosiia"). However, the war that began after the separatist revolt mobilized both Ukrainian and Russian-speaking groups of the population to defend the country. The population of Ukraine consistently supported Ukrainian independence and sovereignty in all regions. Instead, some aspects of state ideological and ethno-linguistic policy were destroying this national solidarity. The implementation of "decommunization" laws has contributed to increasing distrust between the centre and local communities. Language quotas in the Ukrainian media and attempts to ban several social networking sites (that were proclaimed Russian) could heighten tensions between Ukrainian-speaking and Russian-speaking citizens. Finally, in 2017, a law was passed whereby all secondary schools with Russian language teaching, which as early as 2017 accounted for $9 \%$, were to be abolished"37.

The combinatorics of political choice makes it possible to move from hybrid models of institutional interaction (the sources for the creation of which can be found in the Soviet period) to their dialectical synthesis. Nowadays, the combinatorics of political choice should be aimed at tackling the difficult task of improving the effectiveness of institutional interaction in order to ensure defence in a democratic environment.

That is, "... Ukrainian society needs to solve the problem of synthesis of "institutes of peace and economic growth" (political and economic freedoms, free media, information pluralism, decentralization, etc.) with institutions that contribute to the country's defence capabilities (army, power structures, political and administrative hierarchy, etc.) ... in political space, there is a clash of political institutions and relations of democracy that are gaining weight and the remnants of political practices from the Soviet past, to which some citizens got accustomed ... at the present stage of democratization, an important political problem of optimal interaction of those political institutions that appeared at different stages of democratization in Ukraine under different conditions is actualized" 38 .

37 Minakov M. (2019) Postup demokratiji v Ukrajini (1991-2019) [The progress of democracy in Ukraine] SG Sofia website. Retrieved from: http://sg-sofia.com.ua/postupdemokratii-v-ukraini-1991-2019

38 Yakovlev D.V. (2019) Ljudyna i reformy: Kombinaciji vyboru [Man and reforms: A combination of choice] Proceedings of the Ljudyna maje pravo: socialjno-ghumanitarnyj dyskurs u konteksti reformacijnykh procesiv $v$ Ukrajini : materialy krughlogho stolu (Ukraine, Odesa, November 21, 2019) (eds. C. O. Kuznichenko, O. J. Nadybsjka), Odesa : Astroprynt. 
In order to increase the defence capability in a democratic environment, it is necessary to rationalize the institutional interaction between the institutions of the parliament, the government and the president, and opt for one of the electoral systems. Regarding the last point, at least two consecutive election campaigns should take place without significant changes to the electoral model. Voters have to get accustomed to the current political rules and regulations. This research deals with institutional interaction. However, its basis is a political choice. We use it to promote the public recognition that at the heart of all political processes is an individual. He/she evaluates, expects, rationalizes, chooses, and makes choices. A person should be at the centre of all transformations - this is mainly what the theory of choice says. Only "Homo eligit" is capable of generating rational combinations of political choices that will, as a result, provide an optimal model of institutional interaction as a factor in improving Ukraine's defence capacity in the conditions of democracy. It should be noted that, from the point of view of interdisciplinary research, attention is paid to the question: "How was consolidated democracy built in the countries of Western and Northern Europe in the aftermath of World War II?" Instead, we believe that this experience could be useful for Ukraine until 2014, that is, the beginning of the annexation of Crimea and the armed conflict in Eastern Ukraine. Nowadays, we have to look for other examples. The combinatorics of choice in the conditions of the armed conflict is required. Israel, Croatia, Georgia, Moldova should be noted among those countries that were forced to make democratic transit in the face of armed conflicts. They were simultaneously the parties to armed conflicts and were implementing democratic transit. The experience of only the post-Soviet countries (Georgia and Moldova) shows significant difficulties in this process. Rather, they, like Ukraine, embarked on the path of institutional reversals, authoritarian and oligarchic turns, and failed to escape the trap of "hybridity". "Georgia, Moldova and Ukraine are three participating states of the European Partnership that have chosen to conclude Association Agreements with the European Union, often at the expense of relations with their most powerful neighbour, Russia. They are also rather similar in their levels of democratic development. Within a post-Soviet space, they stand out for their relatively high level of democratic freedoms and political pluralism; none of them, however, can be considered a consolidated democracy, and most analysts describe them as uncertain or hybrid political regimes that combine features of autocracy and democracy" 39 .

\footnotetext{
${ }^{39}$ Ghia N., Cenusa D., Minakov M. (2017) Democracy and its Deficits: The Way of Georgia, Moldova and Ukraine towards Becoming European-Style Democracies. Center for European Policy Studies policy papers. Retrieved from: http://www.3dcftas.eu/publications/other/ democracy-and-its-deficitsway-georgia- moldova-and-ukraine-towards-becoming
} 
During the years of democratic transit (with several authoritarian reversals), political institutions had to adjust to either the "super-presidential" or the presidential-parliamentary and the parliamentary-presidential models of the distribution of powers of state, without taking into account the whole set of political institutions and identifying an optimal method of their interaction by the method of combinatorics.

Political actors who have received credibility from the society following the regular presidential and early parliamentary elections are at a crossroads nowadays: they have to choose a model of institutional interaction that will allow them to go through another election cycle. Therefore, the problem of researching the political and legal implementation of an optimal model of institutional interaction as a factor in improving Ukraine's defence capability in the context of democratization using an interdisciplinary approach is extremely important.

Studies of institutional interaction in transit countries, which at the same time need to enhance defence capabilities, will help to understand that political institutions are the result of deliberate rational actions in a changing social environment. This means that the search for an optimal model of institutional interaction as a factor in improving Ukraine's defence capability in the context of democratization requires rational planning and choosing appropriate legal conditions and political institutions.

\section{CONCLUSIONS}

Ukraine may become one of the first examples of a successful transition from authoritarianism and post-communist hybridity to democracy through institutional interaction. The role of the social sciences in achieving this ambitious goal is extremely important.

Firstly, it is necessary to offer a model of individual and collective behaviour for society at the crossroads. This model might be "Homo eligit". It is about interpreting the political process as a series of situations of choice between democracy and authoritarianism, presidential "vertical" and parliamentarism, proportional and majoritarian electoral systems, etc.

Secondly, the social sciences can offer an algorithm of action for an individual in the situation of choice. It is suggested to use the following alternatives to investigate the situation of choice: 1) Individualism vs. Collectivism; 2) Action vs. Structure; 3) Hierarchy vs. Network; 4) Stability vs. Conflict; 5) Rationality vs. Irrationality. Choosing one of the alternatives will allow forming a sound scientific assessment of individual's behaviour in every situation of choice and determine its orientation either on the continuation of "hybridity" policy or on democracy. 
Thirdly, the error in the study of individual institutions under conditions of democratic transit is identified. The success of democratization in the context of the need to improve defence depends on institutional interaction. The problem is not in the presence or absence of democratic institutions but in their interaction. It is only possible to determine the effectiveness of institutional interaction on the basis of a multidisciplinary approach. Using the method of combinatorics allows separating optimally balanced models of organization of power from unbalanced ones, justifying the correlation of the institutions of power with the given process of democratization, the potentials and properties of these institutions in the societies of consolidated democracy, which were solving simultaneously the task of reforming and enhancing defence capabilities.

Overall, the rational political choice of institutions and their combinatorics will allow overcoming the permanent instability of parliamentary institutions, the relative weakness of the party system, the instability of parliamentary coalitions, the closure of the electoral system, preventing government crises and ensuring the democratic rotation of the political elite.

\section{SUMMARY}

The article is devoted to the role of the social sciences in the process of institutional interaction and political choice. It is determined that the mission of the social sciences in a transitive society is to promote the rational choice of an individual. The model of research of a situation of choice on an example of institutional interaction in Ukraine is offered. The method of philosophical combinatorics and the method of choosing from several alternatives are used. This model includes the choice between authoritarianism and democracy, presidential and parliamentary forms of government, proportional and majoritarian electoral systems. In the social sciences, the combinatorics of the research programme on institutional interaction implies the choice between the alternatives: 1) Individualism vs. Collectivism; 2) Action vs. Structure; 3) Hierarchy vs. Network; 4) Stability vs. Conflict; 5) Rationality vs. Irrationality. Choosing one of the alternatives will allow forming a sound scientific assessment of individual's behaviour in every situation of choice and determine its orientation either on the continuation of "hybridity" policy or on democracy. 


\section{REFERENCES}

1. Bilaniuk L. (2016). Ideologies of Language in Wartime. Revolution and War in Contemporary Ukraine: The Challenge of Change. Boston: AST, pp. 139-160.

2. Clement J. (2016). Electoral rule choice in transitional economies. Journal of Institutional Economics, vol. 12, no. 4, pp. 895-919.

3. Conquest R. (2001). Reflections on a ravaged century. New YorkLondon: WW Norton \& Company

4. De Soto H. (2000). The mystery of capital: Why capitalism triumphs in the West and fails everywhere else. Bantam Press

5. Eremenko A., Yakovlev D. (2019) "My dialektiku uchili ne po Gegelyu". Filosofiya v zerkale politicheskoy propagandy: popytka antropologicheskogo podkhoda ["We studied dialectics not according to Hegel". The philosophy in the mirror of political propaganda: an attempt to the anthropological approach] Current problems of philosophy and sociology, no.24, pp. 10-23.

6. Ghia N., Cenusa D., Minakov M. (2017) Democracy and its Deficits: The Way of Georgia, Moldova and Ukraine towards Becoming EuropeanStyle Democracies. Center for European Policy Studies policy papers. Retrieved from:http://www.3dcftas.eu/publications/other/democracy-and-itsdeficitsway-georgia-moldova-and-ukraine-towards-becoming (accessed online 29 December 2019).

7. Gilbert A. (2002) On the mystery of capital and myths of Hernando de Soto: what difference does the legal title make? International Development Planning Review, № 24 (1), pp. 1-19.

8. Golovakha E., Panina N., Vorona V. (Eds) (2000) Sociology in Ukraine. Selected Works Published During 90-th. Kiev: Institute of Sociology

9. Hodgson G. (2001). How Economics Forgot History. London: Routledge.

10. Jay J. (2019). Education or Indoctrination. Discerning the Difference. Free Book site. Retrieved from: https://islidedocs.com/document/educationor-indoctrination-discerning-the-differencefree-book (accessed 25 May 2019).

11. Kroytor A., Yakovlev D., Aleksentseva-Timchenko K. (2019) 'Apostles' of indoctrination: ideological peculiarities of representation of religious choice in the secondary education (based on analysis of expert interviews) Ideology and Politics, no. 2 (13), pp. 127-146. Retrieved from: https://ideopol.org/wpcontent/uploads/2019/12/ (accessed online 31 December 2019).

12. Kulyk V. (2011) "Language Identity, Linguistic Diversity, and Political Cleavages: Evidence from Ukraine." Nations and Nationalism, vol. 17 no. 3 , pp. 627-648. 
13. Kuzio T. (1996) "National Identity in Independent Ukraine: An Identity in Transition. Nationalism and Ethnic Politics, vol. 2 no. 4, pp. 582-608.

14. Kuzio T. (2017) Putin's war against Ukraine. Revolution, nationalism, and Crime. Toronto: Association with the Chair of Ukrainian Studies, University of Toronto

15. Matsiyevsky Y. (2018) Revolution without Regime Change: The Evidence from the PostEuromaidan Ukraine. Communist and Post-Communist Studies, vol.51 no 4, pp. 349-359.

16. Minakov M. (2019) Postup demokratiji v Ukrajini (1991 - 2019) [The progress of democracy in Ukraine] SG Sofia website. Retrieved from: http://sg-sofia.com.ua/postup-demokratii-v-ukraini-1991-2019 (accessed online January 26, 2020)

17. Mitrokhin N. (2015) "Infiltration, Instruction, Invasion: Russia's War in the Donbass". Journal of Soviet and Post-Soviet Politics and Society, vol. 1 , no. 1 , pp. 219-49

18. Motyl A. J. (2001). Imperial ends: the decay, collapse, and revival of empires. New York: Columbia University Press

19. Rabkin Y., Minakov M. (eds.) (2018). Demodernization: A Future in the Past. Stuttgart: Verlag

20. Raišienè A., Bilan S., Smalskys V., Gečienè J. (2019). Emerging changes in attitudes to inter-institutional collaboration: the case of organizations providing social services in communities. Administratie si Management Public, no. 33, pp. 34-56.

21. Ramseyer J. M. (1995) Public Choice. Coase-Sandor Institute for Law \& Economics Working Paper, no. 34. Retrieved from: https://chicagounbound.uchicago.edu/cgi/viewcontent.cgi?article=1393\&cont ext=law_and_economics (accessed online January 20, 2020)

22. Riabchuk M. (1992) “Two Ukraines?”. East European Reporter, vol. 5, no. 4, pp. 18-22.

23. Riabchuk M. (2002) Ukraine: One State, Two Countries. Transit Online. Retrieved from: http://www.eurozine.com/pdf/2002-09-16-riabchuken.pdf. (accessed online 29 December 2019).

24. Riabchuk M. (2015) "Two Ukraine's' Reconsidered" The End of Ukrainian Ambivalence? Studies in Ethnicity and Nationalism, vol. 15, no. 1, pp. 138-156.

25. Šimić Banović, R. (2015). Institutional Interaction in the Business Environment: Eastern European Versus Western European Countries. Zbornik Pravnog fakulteta u Zagrebu, vol. 65, no. 3-4, pp. 439-480

26. Stefes C. H. (2006) Understanding Post-Soviet Transitions. London: Palgrave Macmillan. 
27. Udehn L. (2002). The Changing Face of Methodological Individualism. Annual Review of Sociology, no. 28, pp. 479-507. Retrieved from: www.jstor.org/stable/3069250. (accessed online January 26, 2020).

28. Walker E. W. (2014) "Ukraine: Divided Nation, Divided State. Eurasian Geopolitics. Retrieved from: http://eurasiangeopolitics.com/ 2014/03/14/ukraine-divided-nation-divided-state (accessed online 29 December 2019).

29. Wilson A. (2015). Can Ukraine Save Its Revolution? Current History, vol.114 no. 774, pp. 259-269.

30. Yakovlev D. (2015) Democracy "On the March": Rethinking the Role of Propaganda and the "Party of Power" under Armed Threat. Proceedings of the Scope: science of politics - International Interdisciplinary Conference of Political Research (Bucharest, May 8-9, 2015), University of Bucharest

31. Yakovlev D. (2015) Political choice of Ukraine: alternatives to the Grand Duke and restriction of the last secretary general. Proceedings of the Social and political configurations of Modernity: Political Power in Ukraine and in the World: Materials of the 4th International Scientific and Practical Conference (Ukraine Kyiv, June 3-4, 2015) (eds G. Derlugyan, A.A. Melnichenko, P.V. Kutuev, A.A. Migalush), Kyiv: Talcom, pp. 39-41.

32. Yakovlev D.V. (2015) Alea jacta est: vybir jak element socialjnoji vzajemodiji [Alea jacta est: choice as an element of modern interaction] Proceedings of the Priorytetni naprjamky rozvytku suspiljnykh nauk $u$ 21 stolitti": materialy mizhnarodnoji naukovoji konferenciji (Ukraine, Kherson, February 27-28, 2015), Kherson: Gheljvetyka, pp. 155-159.

33. Yakovlev D.V. (2016) Dylemy vyboru. [Dilemmas of choice]. Young scientist, vol. 7, no. 34, pp. 503-508. Retrieved from: http://molodyvcheny.in.ua/files/journal/2016/7/120.pdf (accessed online January 26, 2020).

34. Yakovlev D.V. (2016) Parlament na rozdorizhzhi: Rada jak instytut politychnogho vyboru [Parliament at the Crossroads: The Council as an Institute of Political Choice] Proceedings of the Parlamentsjki chytannja : 6-ta shhorichn. mizhnar. konfer. (Ukraine, Kyiv, November 18-19, 2016), Kyiv: FOP Zhorin R. V., pp. 12-17.

35. Yakovlev D.V. (2017) Ideja vyboru [The idea of choice ]. Proceedings of the Reghionaljna polityka : istorija, polityko-pravovi zasady, arkhitektura, urbanistyka: Tretja mizhnarnarodna naukovo-praktychna konferancija (Ukraine, Kyiv, November 22-23, 2017), Kyiv: Kyjiv. nac. un-t budivn. i arkhit-ry ta in, vol. 1, pp. 43-48.

36. Yakovlev D.V.(2019) Ljudyna i reformy: Kombinaciji vyboru [Man and reforms: A combination of choice] Proceedings of the Ljudyna maje pravo: socialjno-ghumanitarnyj dyskurs u konteksti reformacijnykh procesiv $v$ 
Ukrajini : materialy krughlogho stolu (Ukraine, Odesa, November 21, 2019) (eds. C.O. Kuznichenko, O.J. Nadybsjka), Odesa : Astroprynt.

37. Young A. (2017) Democratic Dialogue and the Constitution. New York: Oxford University Press

\section{Information about the authors:}

Denys Yakovlev, Prof. dr hab., Dean of the Faculty of Psychology, Political Science and Sociology, National University Odessa Law Academy 23, Fontanska str., Odessa, Ukraine ORCID ID: orcid.org/0000-0003-2828-4669

Liliya Yakovleva, $\mathrm{PhD}$, Associate Professor, Doctoral Student of the Department of Regional Policy and Public Administration, ORIPA NAPA under the President of Ukraine 22, Genuezka str., Odesa, Ukraine ORCID ID: orcid.org/0000-0002-0942-485X 


\section{RESEARCH PROBLEMS OF THE RELATION OF POWER AND SELF-GOVERNMENT IN THE PROCESS OF POLITICAL MANAGEMENT OF THE COUNTRY}

\section{Larysa Dunaieva}

\section{INTRODUCTION}

Modern world development is characterized by crisis phenomena in the functioning of all social systems of the world, which have spread in the world in recent decades, have led to significant consequences in the economic and social space and are increasingly manifested in the sphere of politics. Almost all political institutions and processes, especially the modern states, political parties and other actors of world and national politics, have felt destructive consequences. The political system of countries is in crisis. The models of power and governance that have previously provided for effective governance of the country are changing and proving their inability to meet the new conditions and needs of the times.

The system of governing countries, which is predominantly the sphere of government, is less and less able to respond adequately to the new needs of social development, to influence all social processes, and does not absorb all policy makers. Due to the fact that the state administration does not cover the system of self-government and the sphere of civil society, political scientists argue that it is advisable to change the priorities in the management of modern countries - from state to political administration, capable of covering everything that has to do with politics.

Social practices require urgent changes in the system of government and political governance that can meet the challenges of globalization, the spread of crisis in the world socio-economic space, the emergence of new actors in the political arena, while reflecting historical, national, cultural, ethnic and other features of every country, every society. All this requires the transformation of the political governance model of the modern country, taking into account new opportunities of the authorities and self-governing processes, their rational correlation in the process of political management in practice.

The search for a new model of political governance is also complicated by problems in the social sciences, due to the lack of an adequate paradigm of thinking and a methodological basis for research and analysis of new phenomena in world and national politics. 
Today, political science faces the urgent problem of reviewing the balance of power and self-government in the process of political governance of the country, developing a model of relations between them that would fit the culture of the society, the requirements of time, and forming adequate to the real needs of interactions of power and self-government in the system of political management on the basis of such a model. All this requires the development of theoretical and methodological foundations for determining the place and role of government and self-government in the process of political management of modern societies.

\section{Theoretical and methodological aspects of the study of the relationship between power and self-government}

Modern world development is characterized by the growth of pluralism and the presence of numerous competing paradigms of social development, among which the sociohumanist paradigm occupies a leading position. It emphasizes the change of the place of the person in the social structure of modern society, the growth of the range of his freedom and individuality, overcoming alienation, etc.

The analysis of such paradigms proves that the theory of complex nonequilibrium systems, developed by I. Prigozhin, is today the scientific and methodological basis of most scientific studies, including political ones ${ }^{1}$. It is a fundamental denial of the predictability of the future as a product of selfdevelopment, which cannot be a pre-planned process. One can only hypothesize development trajectories based on quantitative data. However, the normative function of the social sciences is not to construct a future reality, but to find out how it is formed, and at the same time, to promote a more rational reality by comparing social constructs. It is important to understand that such justifications will always be not only relative but also of exclusive use in well-defined systems.

Modernity is characterized by three features: the spread of information technology, globalization and the emergence of networked organizational forms in all spheres of human life. Globalization is the main process that has a dominant influence on the configuration of relations between government and self-government in the process of political governance of modern states.

Globalization refers to the process of global economic, political and cultural integration, the main characteristics of which are: world division of labor, migration across the globe of human, industrial and financial resources, as well as standardization of legislation, convergence of cultures of different S. 23.

${ }^{1}$ Prigozhin I. Vremya. Khaos. Kvant / Y. Pryhozhyn, Y. Stynhers. - M.: Nauka. 1998. - 
countries. In politics, this is manifested as a certain reduction of the role of state power and the shift of emphasis to global international organizations at the macro level, and at the local level - the localization of power at the level of a city-state governed by self-government mechanisms.

Mass spread of information technology and the spread of globalization processes are gradually leading to the formation of appropriate organizational forms - networks, first in the sphere of economy, then in society, and as a consequence, in the political sphere. The first to undergo some changes due to the penetration of network forms into the sphere of political governance is the institution of local self-government, since it is closest to the citizens of the level of government, and by its nature the network is formed on the basis of trust and desire to achieve a common goal.

In this regard, when developing its own model of the political system, Ukraine must take into account the impact of the effects of globalization processes, above all, on economic and political ones. In the new model of the political system, it is important to focus on self-governing aspects, as they lead to the formation of relationships of trust between network members, on the basis of which it is only possible to build a new model of power relations in the post-Soviet political space that will correspond to the realities of the times. "So, in the face of modern Ukraine, there is an urgent problem of finding an appropriate model of government, which is able to satisfy all the requirements of Ukrainian society. It is necessary to devise a form of government that is capable of providing economic growth and strengthening of political formation and, at the same time, contributing to social stability in a society where not many members of the new class coexist, and numerous representatives of the old age, who are largely unadapted to their realities days, and therefore require social assistance from the authorities"2.

The development of a new model of the political system of modern society requires study of both the world and national historical experience of becoming a system of public power organization, government and selfgovernment, and their ideological and theoretical, intellectual understanding.

\section{Ideological and theoretical origins of the organization of modern public power}

Analysis of the political and legal heritage of the most prominent thinkers from antiquity to the present gives reason to claim that the first ideas about the relations of "authority-autonomy" were held within the doctrine of the ideal (perfect or correct) form of government. According to the ancient Greek

2 Dunayeva L. M. Vlada i samovriaduvannia: evoliutsiia dialohu [Monohrafiia] / L. M. Dunaieva / Odesk. nats. un-t, - Odesa: Polihraf, 2009. - S. 65-66. 
thinkers, the ideal form of government can only be a mixed form of statehood, provided that the policy in which the features of the civilian community are preserved is maintained. The political and legal formation of Ancient Rome was something else: the Roman state underwent a long evolution from tsarist power, republican form of government, and to imperial power. Moreover, if in the first stages of the statehood of Rome the essential features of the civilian community were preserved, then during the periods of principle and dominance a vertical of power was formed with a centralized bureaucratic apparatus that controlled the local government.

Political and legal thinking of the Middle Ages on the consideration of options for the interaction of power and self-government is also diverse. In this period, it is expedient to carry out a study of the interaction between the authorities and the structures of self-government, by means of a comparative analysis of the medieval Byzantine (Oriental-Orthodox) tradition and the principles of the Occidental-Catholic tradition, on which both state practice and political-legal theory of Western states relied. A key factor in analyzing both political and legal traditions is that both the incidental and the orientational directions are based on the ancient heritage and the Roman law school. But as a result of changing historical and religious-cultural conditions, completely different state-legal systems were formed, and in particular different approaches to understanding the optimal relationship between central government and self-governing structures in national political systems. In general, at this time, we can distinguish the following main areas:

- Byzantine (Eastern Orthodox) tradition, which saw the monarch as the supreme sovereign, who should combine secular, ecclesiastical and selfgoverning power in his own hands;

- the theological (Catholic) tradition according to which the monarch must submit to religious power in order to legitimize secular power (both central and self-governing);

- the secular tradition of civic humanism, according to which the people are the only sovereign power, but delegate it to a legitimate monarch.

Analyzing the political and legal heritage of the Middle Ages and the Renaissance, it should be borne in mind that the concepts of most scholars of this period were based on ancient heritage, representing a kind of synthesis in the Aristotelian tradition of Italian humanism, the idea of the state, which is based on the achievement of common good and values of self-government structures. For humanists, it is common belief that the goal of the state should be to ensure the happy life of its citizens, and for the sake of this the state should not restrict civic initiatives. Thus, the Italian humanists defended the ideas of socio-political ethics.

The most interesting to clarify the question of political and legal interpretations of the interaction of power and self-governing structures during 
the Middle Ages and the Renaissance is the study of N. Machiavelli's theoretical heritage. The ideal of statehood for Machiavelli is a mixed government in the form of a moderate republic, which is recognized as the most stable in its political development, because it combines several forms of government, as well as different forms of self-government.

Approaches to the understanding of power and self-government of the period (XVIII - XIX centuries) focus attention on the innovations of political life and socio-political thought of modern times, in particular, the establishment of the institution of local self-government and the emergence of ideological and political currents, which led to a rethinking of the relations between the authorities and the sciences in the political practice of the time.

Currently, the basic scientific concepts of local self-government have been formulated, in particular, state, public, natural and legal. Despite the fact that the subjects of their research were completely different politically; from the state, they, each in their own way, came to the conclusion that the true greatness of the peoples was based on a system opposite to centralism. Selfgovernment was defined as an organically inherent social regulator of cohabitation at the local level and a state-legal institute capable of decisively influencing the degree of democratic political systems.

Modern times were characterized by the formation of ideological and political trends, which also influenced the evolution of ideas about the model of relations "authority-autonomy ". Thus, the set of liberal ideas and postulates greatly influenced the idea of power and self-government, which played a revolutionary role in the transition of European countries from feudalism to capitalism. It was thanks to the liberal trend in the late nineteenth century. Most state and public figures were convinced that the basis of a constitutional system of a democratic state should be recognition of human rights, broad self-government, and the relationship between central and local authorities should be based on an equal footing.

The ideal of social order for representatives of other ideological and political currents - anarchists and anarcho-syndicalists - was federalism, full autonomy, independence of local self-government bodies from the center, self-organization of society, voluntary association of production associations, which should be responsible for the organization of production and distribution. The links of the future society proclaimed revolutionary labor unions (unions of industrial and public self-government). On the example of anarchist and anarcho-syndicalist theories, we see that despite all political, social and economic transformations, the overriding value is that people living in one place and in need of certain services should have democratic institutions through which they had would be able to express their interests. 
The initial theoretical and methodological basis for the formation of public, including self-government, in Ukraine is the public and natural-legal concept of power and self-government. These ideas humanize public authority, make it more citizen-friendly, and their implementation substantially broadens the sphere of individual freedom, its social action, forming an essential segment of its social interaction with the state, which optimally realizes individual and collective rights of the individual. Authorities under these conditions reflect not only the specific way of thinking and the form of realization of the will of a particular person, groups of people for the life and life of their descendant. At the local level, such a power will form and operate a coherent system of social connections that actually shape a real civil society.

For the political thought of the XX century the nature and principles of functioning of power and local self-government is characterized by the evolution of scientific ideas about the model of the relationship between "power and self-government". In this time interval, it is advisable to distinguish three stages. Thus, the beginning of the century was marked by the development of the problem within the idea of the rule of law, the Soviet times introduced their vision of these relations, and modernity added its scientific principles and models of relations in accordance with the requirements of modern democracies.

The beginning of the twentieth century proved that the problems of the essence and content of power and self-government are embedded in the content of the phenomenon of self-restriction of state power and movement to the rule of law, as the state that guarantees the most natural rights for the individual. However, with respect to domestic political practice, it should be noted that the bourgeois-class self-rule of capitalist countries has acquired in the USSR the form and content of proletarian-class self-government. This fundamentally changed the notion that existed before the revolution about local government as a non-state by nature.

According to the Soviet approach, the local Soviets freely united on the basis of democratic centralism into a single, federal, consolidated, nationwide Soviet power. Organized into a rigid state vertical, local councils were, in fact, a democratic cover for the party's monopoly power. From the fact that the councils tried to provide traditional municipal services to people with their limited capabilities, their nature did not change. They formed and acted as an organic part of the totalitarian regime. In part, this approach remains in the ideas of the modern population of Ukraine, which is manifested in the fact that people still consider self-government as an extension of state power rather than an independent kind of government.

Already in 60-80-ies of XX century the scientific and educational literature analyzed the problems of self-government of the people in 
connection with the democratic processes that took place in the state and public life of the country, with the activity of councils and the strengthening of democratic principles in government. However, self-government was not limited to the local level, but was considered as a social phenomenon that penetrates into all spheres of life of society and its political system. It was not limited to advice; its forms, such as self-government of public organizations, labor collectives, cooperative, school, student self-government, were actively investigated, which in their totality formed the concept of "self-government of the people".

\section{Modern theoretical and methodological approaches of researching the balance of power and self-government}

Local self-government in the conceptions of modern political concepts is a new "publicity", which, compared to the state, has a different nature of relations between subjects and objects of governance. In comparison to the state, local self-government acts as an equal subject of government, which has autonomy within its powers. Only, unlike the state, local self-government assumes that the entities are the links of the system of their own, not of the state government.

Various terms are used to define political governance within modern science, including management and governance, but the latter is a more inclusive phenomenon that involves not only governmental structures but also informal and non-governmental mechanisms.

There are several concepts of political governance, among which the most common are the concepts of governance as a socio-cybernetic system and governance as self-regulatory inter-organizational networks. In this approach, governance is the result of socio-political-administrative intervention and interaction, and the existing order in the political sphere is not dictated from above but emerges in the process of negotiations between representatives of different structures. These interactions are based on recognition of interdependence; they do not have a single actor, public or private, who has all the knowledge and information needed to solve a complex of existing problems. This approach clearly delineates the difference between public and political governance, recognizing the latter as broader in that it encompasses public administration and civil society, the private sector, and others.

The current concept of political governance as self-regulating interorganizational networks is changing the place and role of government as a leading actor of state power. The government is no longer the basic structure of political governance. The political system is highly differentiated. The objectives of the government are to provide opportunities for socio-political 
interaction, to stimulate multiple and diverse mechanisms for solving problems and for the distribution of services between several actors.

Each country is developing its own version of political governance, but theoretically one can imagine a universal model that would capture all the benefits of the best political management experience. "Governance is a function of content in interaction with form. Therefore, the higher and more adequate the content at the 'input' and 'output' of social integrity, the higher and more adequate the management, and therefore the higher and more qualitative is the form of such integrity" .

In modern political science there is a significant shift in the study and interpretation of the category "power". There is a transition to the next, qualitatively new level - the very way of reproducing the schematism of power. This means that certain options of power become technically constructed. Indestructible things turn into relative ones. Power technologies are evolving, and we are increasingly beginning to relate to power from a technical point of view as we can discuss what type of power is to be established and how.

To realize all the schematism of modern power, it is necessary to recreate its entire integrity. The schematism of power in this sense is realized as a definite, defined configuration, which provides a certain way of interconnecting the transcendencies of power, authorities, elites, places of presence and people. If any of the components is missed, it can lead to negative consequences.

The state is only one of the instances of the authorities, which possesses a rather defined exclusive resource (general procedure and uniformity of procedures throughout the territory) and one which does not substitute for other instances. Historically, L. Montesquieu was the first to record the principle of several irresistible authorities. It is not about the separation of powers - it is not about how one power was divided into three parts, but rather that there are several separate instances of power, each of which has exclusive resources, and these instances have to agree among themselves.

The possibility of multiple instances of power in parallel has given rise to several separate types of power, including political, public, state, local selfgovernment and so on. They are all different in purpose, methods, forms of manifestation, objects and subjects. And the change in power configuration is due to three processes: the integration of trust networks, the isolation of categorical inequality, and the elimination of independent centers of power that resort to violence and coercion.

\footnotetext{
${ }^{3}$ Hrazhdan V. D. Deiatelnost y upravlenye (sotsyolohycheskyi aspekt) / V. D. Hrazhdan. M.: NYY truda, 1989. - S. 36.
} 
The needs of democratic governance require a combination of political governance in the country and state power and local self-government. In most democracies, the regional level of government is the most important, and its management is represented by local self-government and state authorities, which should cooperate at this level on the principles of interdependence and the combination of their own efforts.

In analyzing the regional structure of a society, the general criteria - the characteristics of the subject and the object of power, are taken into account. Subject research involves identifying a source of regional authority that can co-ordinate with central government and be governed by direct government; or act as a regional self-organization of power in the form of full selfgovernment. The object of regional power is characterized by a regional socio-political community, the distinctive features of which are the particular political organization and the presence of integrating political interest.

In the presence of a territorial socio-political community in the region, the laws of its development become a determining factor in the political organization of the region, and all actions are aimed at reducing the powers of the central state power, forming the structures of self-government and selforganization of power. In the absence of such a community in the region, the central source of government and its interests will be the main source of development of its forms. The central government will try to establish its own control in the region. A capable political actor is formed where and when there are not only central government bodies at the regional level, but also a society with all the relevant attributes and characteristics.

Significant reasons for increasing the importance of regional and local levels of government as centers of public decision-making in globalized conditions are the sharp increase in the economic impact of urban areas and the diminishing role of the state. Today, we can talk about different areas of analysis of the place of regions and regional policy in a globalized world, but only the model of "global gates" allows to include and explain the place and role of transitional economies and developing countries in the global globalization process.

Such "gates to the global world" are built on negotiation practices, trade networks and trust, and can exist as shared centers of economic, political, and intellectual networks, and at a distance, distance from one another. "Gates" can be different: "global gates", which are centers of transit trade and credit for the whole "world-economy" and "quasi-turn", which are the center of the "world-empire" - the world, built on the administrative and political domination of networks power. As a result of the quasi-turn, only politically controlled countries attract resources. The former are based on a broad democratic basis, in particular involving self-organization and self-governmental 
processes within networks, and the latter requiring a strong political and administrative influence over the controlled territory, which implies the strengthening of power and the partial curtailment of self-government and self-organizational processes.

The analysis of modern political systems needs to be considered in terms of the principles of the distribution of power vertically, namely between the central government and the regions, their local structures, which is especially important for understanding the problems of interaction between the authorities and local self-government.

Under unitarianism, the separation of powers between the various instances of government in the state is carried out by the central authority local self-government bodies, and the principle of separation of powers should be supplemented by a system of checks and balances, which under conditions of unitarism works for the benefit of the central government. Federalism gives a different configuration of power in the state, since it adds hierarchy to the very structure of power that is enriched in the federations by an additional level of concentration of power - the subjects of the federation. The peculiarity of federal power-building is the shift of power accents to the middle level - the level of subjects of the federation where the efforts of the central authorities, as well as self-government of different levels, must be coordinated and harmonized.

From the second half of XX century the concept of a "new federalism" is gaining ground in the global political field, which places greater emphasis on the autonomy of territorial self-governing units, taking into account the interests of ethnic and national minorities, the role and function of regional elites. This approach adds even more hierarchy to the system of government, since it also has primary centers of self-government (neighborhoods), which, on the one hand, complicates the system of government, and on the other, promotes the unification of political governance systems in all modern states, a federation is a unitary state.

It is possible to combine the gains of both federalism and unitarism within the limits of a new scientific-theoretical and practical approach - regionalism. This is where his supporters come from. They consider the region to be a link to governing the state, which is recognized by both federalism and unitary states, and globalization challenges call for local problems in an urgent and unified scenario, making regionalism an increasingly widespread scientific area of research and practical policy action.

Such a theoretical and methodological basis for the organization of power and its interaction with local self-government can be served by many principles proposed by the world government, in particular, systemic, hierarchical, democracy, etc., however, the ones that are recognized by the 
world as the most effective are the principle of decentralization, subsidiarity and control. In their content, they are a significant complement to the principle of separation of powers, detailing and prescribing those theoretical and methodological foundations on the basis of which the process of political governance in the modern state should take place.

The principle of decentralization is a complex phenomenon, since it is necessary to clearly understand the difference between decentralization of power and decentralization of government on the one hand, and between decentralization and deconcentration on the other. The decentralization process involves the transfer of the right to make decisions independently to the lower levels of government, but there is a prerequisite - these lower levels of government must be governed by elected councils, that is, self-government. The process of devolution of power implies the transfer of powers to perform only within one branch of power - the executive, and therefore can only be considered within the limits of public administration.

One example of a rational decentralized government is the experience of France, the main characteristics of which, according to B. Gourne, are that:

- the region is transformed into a territorial community, which, as communes and departments, is governed by freely elected councils;

- Heads of Assembly of Territorial Communities were given more power;

- the state guardianship has been abolished, but the state continues to exercise administrative control over certain actions of territorial communities, as well as control over certain budgetary operations;

- decentralized communities have benefited significantly from the expansion of their mandate;

- the state's financial support has become global ${ }^{4}$.

Another important principle of political governance is the principle of subsidiarity, which has long-standing historical roots and rich experience in the application of political practices in European countries. According to this principle, at the lower level of government, such powers should be concentrated that the community is able to fulfill on its own, but subject to material and financial assistance from above. Only functions that the community is unable to master are passed to the highest level. Each country, in each specific historical period and taking into account all historical, cultural and national-mental levers, determines independently the amount of powers that the self-governing community is able to fulfill on its own and at its own discretion.

${ }^{4}$ Hurne B. Derzhavne upravlinnia [per. z frants.V. Shovkuna]. - K.: Osnovy, 1993. S. 14-31. 
When applying the principles of decentralization of political governance and subsidiarity, it should be remembered that only powers are delegated to the lower level and vice versa, and the responsibility rests with whom it naturally belonged. In addition, one should not forget that no matter how you act or delegate authority, the power remains united.

Delegation and distribution of powers between different levels of government, especially given the inability to delegate responsibility, requires the application of the principle of control. For now, such control has two directions. One is the control of the authorities, and in particular the supervisory bodies specially created for this purpose, and the other is the public control. The latter is favored, as voter control is an effective form of control in leading democratic countries, and control of independent civil society organizations is gaining momentum.

Modern Ukraine is in a state of search for an optimal model of the relationship between state power and local self-government. In this direction, the political system of modern Ukraine is being reformed, with the aim of establishing a new model of government: a person - a community - a state that is responsible for the democratic rule and realities of modern sociopolitical and economic life imbued with globalization processes and all its consequences: poverty, social intensity, localization, etc.

For the implementation of such a model of the political system, a number of reforms have to take place, which can be structured as follows: constitutional reform - administrative-territorial - land - budgetary and tax governance reform - reform of local self-government. It is the preservation of such consistency that will allow building the basis of the whole model of political governance - a strong and effective community, capable of meeting the needs of every citizen of Ukraine, bringing the whole system of government closer to the human level.

The reform of the principle of decentralization of power, with an emphasis on its action not only at the level of the local community but also at the level of regional self-government, needs to be improved during reforms. Regional self-government should truly become an institution of self-government, not of government. For this purpose it is advisable to introduce executive committees of regional councils and give them considerable competence in managing the territory of the region. This will implement the principle of decentralization not only of government but also of power, which is a requirement of a democratic state of the modern European model.

The next step is to improve the implementation of the subsidiarity principle in our country, which should be supported by an appropriate material and financial basis. This can be achieved through land and fiscal 
reforms aimed at strengthening territorial communities and their interest in the economic development of the territory.

Further reform of the system of government in Ukraine depends on society, on its activity in discussing the concepts of reform and encouraging existing politicians to take appropriate action through public organizations, political parties, etc.

\section{CONCLUSIONS}

The analysis of the theoretical and methodological foundations of public power, the correlation and interaction of power and local self-government in foreign and Ukrainian special literature indicates an active search for an adequate theoretical basis for transforming existing models of political systems to meet the needs of contemporary historical challenges. This is especially true of the crisis-stricken Ukrainian society, which is seeking a model of government and government that can provide political stability in society and in power, find a way out of a lasting political and economic crisis, foster confidence-building in society, etc. This requires reforms that are appropriate to begin with administrative-territorial, then reforms of local selfgovernment, which aim to form in Ukraine a strong institution of local selfgovernment, strengthen the regional level of government and strengthen the local community as a socio-political community aspiring to self-government. Political reform should be conclusive, where all the gains of previous reforms will be concentrated and brought into line with central government institutions.

The new model of political governance, to be developed in accordance with the conditions of modern Ukraine, should have three levels: center region - community. The balance of power and self-government in such a model will be equilibrium, since the three links will coordinate power in the way of authority. Thus, the highest concentration of power should be concentrated at the center level, as all the main institutes of state power and administration - the Parliament, the President, the Cabinet of Ministers, committees and departments - are represented in the capital.

The leading link in such a model of governance should be the region, at the level of which must be balanced both by the government and the selfgovernment. Only such an equilibrium way of balancing power and selfgovernment and regional levels will allow it to develop steadily. This approach to the consideration of regional governance will strengthen the whole system of political governance of the society and will allow the regional centers - big cities-metropolises to claim the status of regional gates in the global world, to ensure the development of the whole society. 


\section{SUMMARY}

The article deals with theoretical and methodological, ideological and theoretical origins of public authority and local self-government in their genesis, interaction and correlation. These issues are considered on the basis of modern conceptual approaches of forming a new model of the system of governance and self-government in Ukrainian society.

\section{REFERENCES}

1. Dunayeva L.M. Vlada i samovriaduvannia: evoliutsiia dialohu [Monohrafiia]. Odesk.nats.un-t. Odesa: Polihraf, 2009. 356 s.

2. Hrazhdan V.D. Deiatelnost y upravlenye (sotsyolohycheskyi aspekt). M.: NYY truda, 1989. $150 \mathrm{~s}$.

3. Hurne B. Derzhavne upravlinnia [per. z frants.V. Shovkuna]. K.: Osnovy, 1993. $257 \mathrm{~s}$.

4. Pryhozhyn Y. Vremia. Khaos. Kvant. M.: Nauka. 1998. 438 s.

Information about the author:

Larysa Dunaieva,

Doctor of Political Science, Professor

Odesa National I. I. Mechnikov University 15/13, Tenistaya str., Odesa, 65009, Ukraine 


\section{PECULIARITIES AND DIRECTIONS OF THE WORLD POLITICAL AND IDEOLOGICAL DOCTRINES' EVOLUTION IN MODERN CONDITIONS}

\section{Natalia Hedikova}

\section{INTRODUCTION}

The process of global changes has always been connected with the changes in the system of traditional values and fundamental socio-cultural principles and their replacement by the new ones. The specifics of these tendencies' manifestation has a number of scientific justifications, but the key one is the discrepancy between the nature of socio-political thought and ideas and concepts that are formed on its basis and are reflected in certain ideologies and processes of social development and civilization as a whole. This is connected with the accelerating rhythm of social development and radical changes which inverse human thinking and being itself. Naturally, these circumstances require new ideas and concepts, while classical ideological trends do not lose their significance. Depending on the historical epoch, national peculiarities, positions of the theorists and actions of political figures and based on their ability to modernize themselves in accordance with specific conditions of the social order, they acquire new, sometimes not inherent from the beginning features, all the time evolving and transforming in the process of adaptation to the real situation.

Ideology, as a socio-political program formed on the basis of the spiritual potential of a particular social group, or of the entire social universe, is a manifestation of their worldview, consciousness and behavior, encompassing all spheres of public life, based on the values, norms and rules adopted by the majority. It is born, formed and modernized through human relationships, conditions and needs for the development of society. Therefore, in the course of their development, and even more often, when implementing different directions of political thought in practice, they often perceive certain elements in completely opposite directions, changing their essence with minimal changes in terminology. In this regard, the division of society into liberals, social democrats, conservatives, etc. is often conditional.

Numerous public opinion polls show that in relation to different aspects of economic, political, social and cultural life, people can hold different positions, thereby carrying simultaneously the ideas of several political directions. Based on this, it can be noted that every flow of public political thought in its pure form exists only in classical theoretical formulation. 
In practice, there is a combination of the most important elements of liberalism, social democracy, conservatism, etc., their interdependence, and this is a characteristic feature of the modern world system as a whole, focused on universal ideas, ideals and principles.

\section{Modern value foundations and principles of the three world ideologies: liberalism, social democracy, conservatism}

In the history of ideologies, there has always been a dispute that one or another ideology can more deeply understand and assess social phenomena and processes occurring at a particular historical moment, and on that basis, to program and adequately use its own theoretical and practical potential, methods and technologies aimed at dynamic, balanced and progressive development of society and civilization as a whole. In this regard (and in the current conditions of social development it is clearly manifested), there are some opinions that a certain ideology is the only possible and rational in respect to a social project.

Obviously, any subject that identifies himself with this or that theoretical tradition has the right to uphold his conceptual values and principles, to claim his benefits - a natural process inherent in the worldview of individuals and their attitude to reality. The positive character of this condition is that this tendency does not allow ideological uniformity to take shape and to be entrenched, the uniformity which can lead to rather profound negative consequences, especially within the whole world system, and on the contrary, allows ideologies to restrain one another from extreme forms of manifestation and is a driving force of social evolution and real social progress.

Each ideology is guided by certain values and principles in its attitudes, outlook, and political activity. Herewith, within each modern ideology, a number of currents, trends, types and models are distinguished, where the basic values and principles are highly contradictory. It all depends on what the ideologist takes as the basis for solving a particular issue. In this respect, the author of this study believes that it would be logical to conduct a further examination of this problem, based on the general trends of each of these ideologies. And treat each ideology as a coherent ideological phenomenon.

Thus, the basic values and principles for liberalism are freedom, individualism, and equality. For modern liberalism, freedom means the real possibility of choice, which implies its developed and differentiated understanding. At this stage of development, all kinds of freedom (with a wide range of subspecies) fall within the field of view of liberalism, each of them corresponds to a particular sphere of activity. This spectrum is quite wide: worldview, political freedom, social, economic, creative, freedom of love, etc. Recognizing the contribution of liberalism to the development of 
human freedom, it is impossible to neglect the fact that in its modern dimension, it represents the world as an example of not only freedom, but also of its certain limitations that have become the dominant of social development. Liberalism defines freedom as lack of coercion, but at the same time it is limited by legal and moral law aimed at protecting the individual's and state's interests. It is the state that is to establish the balance between freedom and law within the liberal field.

Liberalism in substantiating the principles of individualism, on the one hand, focuses on the idea of the autonomous existence of each individual; on the other hand, it is based on a holistic approach whereby a person is viewed as a social being who needs to cooperate with other people, he / she focuses on his / her social environment. The principle of individualism is focused on the social protection of human rights, their dignity and sovereignty, their independence and self-sufficiency as a member of the community, their ability to withstand external influences.

A liberal understanding of equality is built not on the idea of social equality, but on the legal equality. Modern liberalism argues that people in society can be equal under the law in obtaining civil rights, in the right to property, etc., but they cannot be equal in their mental and physical capabilities. Thus, it insists that the legislation should take into account individuals equal both in origin and in ability. At the same time, providing equal starting opportunities the legislation should not restrict the rights of people who are more capable.

The basis of the social and democratic phenomenon is freedom, equality, social justice and solidarity. It is the principles of "justice" and "solidarity" that are the main peculiarities of social democracy in relation to liberalism and conservatism. In this context, the opinion of the authoritative Ukrainian researcher M. Popovych, who studies the principles of "justice" and "solidarity", is exactly relevant to those features of the ideology of social democracy that make it different from the liberal and conservative ones. The scientist points out that "pure" liberals uphold the principle of noninterference in economic life, insisting that everyone should break out of poverty - then society will be "effective", will become richer and give the poor more chances. Social democracy is sometimes willing to sacrifice efficiency in the name of justice. It seeks to avoid such a situation where success is achieved "at the expense of the weaker", at his expense. M. Popovych maintains that Western social democracies, no matter how radical their programs are, always stopped before the steps that required authoritarian consciousness. Without giving up collectivist political morality, they formed its personality-tolerant character. Social-democratic ideology demands solidarity with the poor and the weak - not only in their nation-state, 
but also on a human scale. Ignoring the actual inequality of people, the uniqueness of each individual with his talents and disadvantages, the inevitable difference in income and vital luck, social democracy stands for "justice" as "equality of rights and opportunities" for every member of society. According to M. Popovych, the principle of "freedom" means, first of all, political democracy with all individual's rights which it provides. Social democracy is no different from that of liberals - it also regards political freedoms as only part of what a person in a free society is entitled to. Political freedoms express a person's right to participate in governing a state and society. But in addition to this right, a person must have a number of other inalienable rights ${ }^{1}$.

His opinion is supplemented by the ideas of S. Prutliak, who believes that "in the context of a rational and critical paradigm, social-democratism means a civilized level of social development. It is a conceptual definition of an open democratic society, aimed at reproducing the humanistic system of values, the culture of power and politics, the responsibility of power institutions, the legitimation of relevant structures, politicians etc. It is the values of social democracy that reproduce the specifics of a civilized society, embodying the ideals of the freedom of the individual, of the spirit, of the value of a legal social state. Social democracy sees the foundation of freedom not in private property, but in equality of rights and opportunities, in political and social protection"

It is very difficult to determine universally accepted traditional values in conservatism, since the filling of their meaning in all nations, peoples, social groups, etc. is different and depends on the historically formed mentality, national and cultural, spiritual traditions of a particular socio-political community, the formation of a social and political community fundamentals, collective identity, etc., on the particular circumstances (conditions) in which the political decision is made. Therefore, there can be no single approach to understanding the traditional values. And at the same time, based on scientific works that give an idea of conservatism and a wide range of its values, the key things are stability, law, order, and tradition. In this context, the opinion of the academician of the NAS of Ukraine B. Danylyshyn seems quite relevant, he believes that "the philosophy of conservatism emphasizes the importance of stability as the embodiment of order and tradition. Freedom is also important

1 Попович М. Соціал-демократична позиція в умовах України. Лівоцентристська перспектива України : збірник експертних матеріалів. URL: http://www.online.km.ua/ igs/leftcent.html\#0

${ }^{2}$ Притуляк С. I. Український вимір світової соціал-демократії періоду постбіполярності: пошук оптимальної моделі взаємодії. Прикарпатський вісник НТШ : наук. журн. Івано-Франківськ. Думка. 2013. № 3(23). С. 121. 
here, but not as a central value (which is characteristic of liberalism), but as a condition for providing order. Similarly, order and tradition in the modern philosophy of liberalism are considered a prerequisite for the realization of individual freedom. The same applies to private property, whose importance is justified by conservatives and liberals. But with the difference that for the former it is a condition of order and stability, for the latter it is a condition of free human development" 3 .

Undoubtedly, liberalism, social democracy, as well as conservatism and other political directions, have an inherent appeal to established traditions, social morality and culture. Yet, in this matter, conservatism is notable for its adherence to historical time, which is justified in the organic synthesis of the past, present, and future prospects, based on the principle of socializing existing experience and preserving historical traditions.

Theoretically, the state, the people and other social subjects can be considered without a historical past, but practically their real existence and dynamic development is impossible without this aspect. Modern liberals are aware of this fact because in the history of the liberal ideology existence, they have often built its ideal constructions, leaving behind historical, national traditions which led to its discrimination.

Modern conservatism recognizes the universality of such concepts as individualism, personal freedoms, human rights and obligations, equality under the law, it upholds the ideas of free competition, free market, social reforms, welfare state, state regulation of the economics, while advocating for state intervention into a market economics and promoting entrepreneurship etc. O. Kuleshov's opinion seems to be correct in this context, he believes that "modern conservatives, apparently, under the influence of liberal demands of personal integrity, allow for value compromises. Nevertheless, the possibility of compromise is assessed differently. However, the prevailing trend in modern conservatism is the doubt that value compromises can be reached. Differently interpreted values are incomparable, but it does not imply a need for tolerance, but for upholding one's own values. What distinguishes modern conservatism is the sense of the limit behind which compromises lead to the loss of basic social values and social order in general. Conservatism is fundamentally opposed to fashionable theories of value pluralism, moral relativism and multicultural tolerance. This position leads to the acceptance of the inevitability of conflict in today's world. Admittedly, historical optimism is not characteristic of modern conservatism"4.

3 Данилишин Б. Лібералізм і консерватизм - Інь і Янь. Дзеркало тижсня. Вип. 45. № 1220, 24 листопада - 30 листопада. URL: https://dt.ua/gazeta/issue/1176

${ }^{4}$ Кулєшов О. В. Проблема цінностей в сучасному консерватизмі. Вісник Черкаського університету. Серія Філософія. Випуск № 31 (324). Черкаси, 2014. С. 26. 
Therefore, based on the foregoing we can claim that among the wide range of value propositions in each ideology, in reality, there are several basic values that are recognized by the majority of people in democratic societies and integrate ideologies that are amenable to analysis. It is freedom, equality, order, tradition.

Freedom is understood as the possibility of each person's selfdetermination and the right to individual self-development. In this case, it is not only about the freedom of the individual, but also about political freedom - the right of the individual to participate in governing the state and society. The constitutional consolidation of freedoms and rights, their regulation and protection by the law, and the provision with the property are the necessary conditions for the free choice of the vital position of every citizen. In doing so, the legal aspect of freedom must necessarily be integrated and commensurate with the principles of personal responsibility and obligation. In the economic sphere, these are free market relations.

The very concept of economics implies a process of social and political regulation in the totality, and it is the sphere of social development that allows to fully reveal the potential opportunities and needs of the individual, where he can most fully realize and improve himself.

At the heart of the modern economics is its key factor - technological progress, which leads to the growth of production, activation of trade flows, financing and investment, expansion of consumption and markets, activation of labor migration, competition and productivity, changes in its nature, etc. Participants in the economic process (people directly) are no longer seen simply as a workforce, but as direct creators of their interests and needs.

The formation of such economic structures is formed under the influence of information technology development. The information space allows a person to deepen the process of knowledge, which is the basis for the formation of intellectual capital, on which the progress in the economics and the well-being of modern society depends in this or that way.

Based on the idea of equal value of each person, the category of equality is understood as equality of initial opportunities, and not equality of the distribution of income, equality of rights and opportunities for every member of society and equality of all members of society under the law, while not ignoring the actual inequality of people. More broadly, it is social justice.

True order in society and the state can be achieved based on the rule of law.

At the same time, it should be noted that the issue of freedom, equality, law, justice and their interrelation among liberals is developed much wider and deeper than in other directions of socio-political thought.

Tradition does not exist on its own and is not separate from certain time. This is evidenced by the fact that every created imperative, a phenomenon 
(including ideology), is natural or artificial in the traditional way for the particular era in which it was formed. And, in the process of succession, it does not lose its significance in the course of the historical development of society, civilization as a whole, thereby acquiring the content (including in the concept) of tradition. Tradition is not a constant, because it constantly changes its socio-cultural content, depending on social reality and the laws of social development.

In addition, it should be borne in mind that each ideology has its own vector of awareness of social life, which is formed based on its common values, priorities, functions and tasks, and in each of them they are sufficiently structured, therefore, they cannot be identical and create a whole ideological field.

The peculiarity of modern liberalism is that in its theory, it does not create new directions and trends, but proposes adequate projects to be solved based on the needs and priorities of time, which are connected with the formation of the foundations of a new society. This is where its relevance and advantage lies.

The peculiarity of modern social democracy is that it responds very quickly to external changes and integrates them into its doctrine in the shortest possible time.

As far as conservatism is concerned, it should be noted that it has traditionally been regarded as a special type of socio-political thought that appeals to the protection of values, institutions, social structures existing at a specific historical period, etc. If such narrow understanding of conservatism was followed, it would have lost its viability, its theoretical and practical relevance. However, its ability to respond to changes in civilizational development makes it possible to claim that this ideological phenomenon is moving and revolutionary. Therefore, it is capable, like other ideologies, of changing its internal attitudes and positions. Thus, the content of conservatism also changes.

Undoubtedly, conservative ideology, in particular, as Ukrainian researcher V. Slobodian believes, feels considerable pressure of the historical past and political present, which causes a certain transformation of the main ideological nucleus. But despite this, conservatism is characterized by certain dominants. Unlike the other two major ideological systems - liberalism and social democracy - conservatism is an anti-progressive philosophy whose methodology is not philosophical theism, but some form of rationalism. Conservatism is seen as a phenomenon of the Christian socio-cultural worlds. As a phenomenon of society's political life, conservatism makes it possible to involve the potential of the public masses in the process of state-building due to understanding its cultural identity and its own historical path of political development ${ }^{5}$.

5 Слободян В. Консерватизм як ідеологія державотворення: етапи становлення. Державне управління та місиеве самоврядування. 2015. Вип. 3. С. 70. 
The ideas about the values, fundamental foundations and goals of human development are constantly changing, and so is the evolution of ideologies. In this regard, it is possible to say that the modern "global world" diminishes the existence of a particular ideology, which was difficult to see in the second half of the twentieth century. Thus, every political phenomenon began to shift into new qualities and acquire new kinds. Thus, from the beginning, it is necessary to ask questions about the criticism of mass activity, its certain groups and individuals.

\section{Modern evolutionary changes in the world political nd ideological doctrines}

The tendencies of modern changes in the worldview constructions of liberal, conservative and social-democratic ideologies in a number of normative values and principles were caused by the fact that the second half of the twentieth century was clearly marked by their ideological decline. As a result, prophecies (which came largely from ideological opponents) have emerged predicting that these ideologies were losing their ideological basis and relevance, which had to inevitably result in their disappearance. In the last decades of the XX - the beginning of the XXI century, the processes of posteconomic transformation and the global cardinal changes that took place in the society led to the desire of a number of ideologies to defend their priority. Based on this, new ideas and concepts about the "end of history", "end of future", "end of politics", "ideological crisis", etc. appeared at the end of the twentieth century, and were actualized at the turn of the last two centuries.

There are a lot of ideas about the ideological crisis, but the essence of the question is to think about these hypotheses and to assess them objectively. Thus, we can say that the liberal, conservative or social-democratic ideology at a certain stage of historical development in a particular country did not have a leading position any longer. And there are enough reasons for this, but the key reason is that the subjects who used it in the context of a particular reality, could not always coordinate their actions adequately to the theory and practice of the ideology itself, and based on this develop new models and mechanisms for implementing its ideas and positions.

Modern scientific provisions have a rooted idea that at a certain stage of the society development, ideology is losing its importance for the further public use and development of the individual, society, and the state. Thus, it either suspends or stops the process of its large-scale existence in order to undergo significant correction again, but in a new perspective. For example, communist ideology ceased to exist as an ideology for a large part of the world-wide population, but it received its renewed continuation in sociopolitical associations (parties, unions, etc.). In the same perspective, we can 
talk about a number of other ideologies. In particular, regarding the political and ideological doctrines considered in this study, it can be noted that a number of their values, norms, ideas and provisions have received their new justification and practical implementation in other ideological models.

In this regard, we cannot claim categorically that we observe the "collapse", "end", "fall" of a particular historical process, or that according to the laws of nature, "it is only the universe that is eternal", and all other dimensions are subject to cycles, changes, transition to other states, and most of all it is to do with ideological projects created by man and his own society, and which are in constant search. And partly in the search for the best. However, such searches do not always produce positive results. But the best that was worked out in this process has still remained and enriched, even when choosing a different path.

Based on this, it should be noted that the theoretical justification of the ideologies under consideration cannot be defined by terms such as "crisis", "end", etc., which can, in fact, be attributed to its ideological and practical state, since scientific knowledge, which has been subjected to continuous updating, supplementing and correction, is a constantly developing and improving phenomenon which can be a basis for any ideology. This, in fact, is evidenced by the whole process of development of world political and ideological doctrines, both in theoretical and practical application. Thus, their ideological decline should be regarded as the starting point of the process of modernization changes in themselves and in treating them.

So, political practice has shown that despite certain difficulties connected with the application of approaches and methods established in the era of industrialism, each of them at the end of the last century was able to comprehend the ineffectiveness of some of its traditional principles and thereby modernize itself in accordance with the objective situation and the tendencies of an ever-expanding democracy. Thus, the standard of ballancing the three leading ideologies of history and modernity is democracy, and there is a task of rethinking the previous hard confrontation between the ideologies mentioned above.

Modern socio-political science believes that the democracy of the present model should, above all, be regarded as an ideal that serves as a guide for the society development. On this basis, within the framework of democratic principles and rules, modern political and ideological doctrines - liberalism, socialism, conservatism etc. build their program provisions and carry out practical activities. Such changes occurring in the ideological settings of these political phenomena lead to the fact that in the process of crossing the boundaries of the democracy sector with the ideology of liberalism, socialism, conservatism, etc., a new form (type) of ideology is created. As a result of the synthesis of democracy and liberalism, there was an ideological unification of 
these constants in a liberal democracy, which combines the political principles and rules of the first, and the legal and economic principles of the second ideological phenomenon; between democracy and socialism appears social democracy with principles of humanistic, progressive development of society and socially oriented economics, in the course of interaction of democracy with conservatism the following takes place: appeal to traditions and values of the past in order to get an answer to the key issues of nowadays, the need for modernization changes at the level of human consciousness, motivation for activity and behavior.

In modern conditions of dynamic development of society and civilization, some tendencies of convergence between liberalism, social democracy and conservatism are traced, which determines the character of evolutionary changes in their political and ideological doctrines. This is not a new historical fact, born by modern times. The apparent convergence of conservatism with liberalism can be seen even in the postmodern era, whereas so far in all spheres of socio-political life (politics, economy, religion, art, culture) there had been a pronounced opposition between them that emerged from the very essence of traditionalism and innovativeness itself since conservatism relied on the first and liberalism on the second. In this era, liberal ideas were filled with the conservative content, conservative ideas - with the liberal content. Tendencies of liberal and social-democratic ideologies' convergence in their vector direction began to appear in the first half of the twentieth century and its subsequent period, when the issues of socio-political and socio-economic regulation of social relations, national sovereignty, strong and responsible statehood, reforms, appliance of the institutional approach to solving emerging problems etc. were actualized. And at the end of the twentieth century, due to the global changes in the geopolitical space, the transition from industrial to post-industrial society, changing of the emphasis by means of accumulating the processes of social development, no longer within national states, but at the global level, changes in the prospects of civilization which gave rise to the problem of choosing a political orientation adequate to the demands of the times, interests and expectations of the society and many other circumstances that significantly changed the whole world system as a whole, this fact became dominant.

Social democrats and conservatives, based on the liberal conception of the human personality value, focus their attention on the development of human individuality, the social significance of their rights and freedoms, needs, way of thinking and behavior, creative opportunities, responsibilities, which in their individual meaning are a prerequisite for the collective phenomenon formation. Moreover, in the present circumstances, collective values are inferior to individual values, and individuals join certain communities, groups, etc. only to realize and defend their own interests. Thus, the concept of collectivism as such loses its 
value and importance and gives way to a new form of relations - territorial communities, which both social democrats and the liberals appeal to, this extends the possibility of practical interaction of the two ideologies.

Meanwhile, social democrats have not completely renounced the role of a collective phenomenon in society (renouncing its importance and role in the theory and practice of Soviet socialism), and conservatives - the importance of the community (family, ethnicity, nation, society, etc.), explaining it by the fact that complete individual's self-development and self-expression, his spiritual and cultural formation are hard to imagine without them. In this case, conservatism is closer to the socialist tradition, since both trends defend the principle of collectivism, which opposes individualism, the priority role of the state in relation to other social subjects (personality, society), the idea of the society unity (on the basis of nationality, ideality, government goals, etc.).

However, when it comes to the realization of modern liberalism in the community (as a unity of citizens), one cannot help but admit that liberalism is aware of its importance from certain points of view. Assessing the motives for successful society development (stable balanced economics with high efficiency of productivity, high standard of living, balanced relations between the state and civil society, etc.), liberals are convinced that the implementation of projects and achievement of the set goals, the use of management technologies, the use of management and other forms are possible as a result of public consent and informed choice of citizens.

Based on the above-said, it should be noted that the liberalization of the ideology of social democracy and conservatism brought these political phenomena to a change of priorities, a positive assessment of some aspects of individualism and collectivism, and updated the interpretation of these categories.

At this stage of its existence, the ideologies we are analyzing have diverged from their previous methods and mechanisms used in meeting the needs of social groups and their organizations and in addressing emerging issues. Liberals, social democrats and conservatives are convinced that the demands put forward by society can be solved and implemented by peaceful means, by gradual evolutionary transformations. The transition to a more sophisticated social system should not be forceful, but should be gradual and transformational. Thus, based on Marxist theory, social democrats abandoned the idea of conducting social changes and changes in the system by means of social and political revolutions. At the same time, conservatism, as a supporter of evolutionary development and change (which makes it closer to liberalism), in contrast to the explicitly categorical demand for a return to the old order that underlies reactionary political doctrines, is philosophically and socially political phenomenon, which is evolving and changing; although it manifests itself differently in certain situations, but still it follows the tendencies of social progress assessing objectively the prospects for social development. 
At the end of the twentieth century, well-known reasons and a number of specific problems brought the social state to crisis. However, neither neoliberalism nor neo-conservatism, which sought to take the place of liberalism and correct all its shortcomings, nor the changes that took place in a number of political systems and in the structure of the bipolar world, solved the problems imposed on the social state (increased unemployment, low salaries, poverty, illiteracy, social insecurity of certain categories of population, serious demographic changes, unprecedented tension of social contradictions and conflicts, etc.). In this regard, scientists and politicians are tasked with finding the best ways to solve social problems. Within these trends, representatives of the three main ideological and political movements (liberalism, social democracy, and conservatism) proposed a new concept of a welfare state. Modern European liberals and social democrats, while acknowledging the shortcomings of the "welfare state", did not abandon it, but replaced it with "welfare society". In fact, decentralization of the state functions, in particular, in the realization of their social and political sphere, and their transfer to regional, local authorities and civil society, is recognized as necessary. These social and political entities, in accordance with the provisions of decentralization of governing structures, have the right to voluntarily fulfill their statutory powers and functional responsibilities. Thus, state intervention in all spheres of social life becomes superfluous, therefore, the state becomes a coordinating and regulating body. Moreover, it abandons the state control over economics that is common to the two ideologies under consideration.

The welfare society offers an active role of the welfare state in creating the conditions that allow each individual to self-actualize and conduct their own activity.

Each of the ideologies under study offers its own model of the welfare state. In this context, we consider quite correct the opinion of the national researcher D. Skovronsky, who notes that the liberal model of the welfare state is characterized by the principle of individualism, which assumes everyone's personal responsibility for their own destiny, the destiny of their family. In this case, the role of state structures in the implementation of social policy is minimized. Its main subjects are individuals and various nongovernmental organizations - social insurance funds and associations. The conservative model is based on the idea of introducing social differentiation in society. In this model, property inequality is a normal phenomenon, and the main task of the state is to redistribute income by means of flexible tax policy, to provide compensation for those who need it. The social-democratic model, as D. Skovronsky argues, aims at preventing sharp differentiation of income levels. Social guarantees are provided both by the state and non state structures. The social policy of the state is aimed at providing all citizens with a job. The formal absence of unemployment forms a stable tax system. The level of taxation is better than in the liberal model. 
This enables the state to redistribute the centralized fund, providing citizens with social assistance. The directions of social policy are directly derived from the social rights of the population ${ }^{6}$.

At the same time, the peculiarity of the modern approach of these ideologies concerning the social state is that the state social expenditures, which significantly weakened the institution in the 1970s - early 1980s, are delegate to the society and individuals. In this regard, the welfare state focuses its efforts on investment in human and social capital, which does not involve provision of a job, but provision of education, the possibility of obtaining new professions and the creation of new jobs.

Thus, modern social democrats in social development carry out a process of transformation from a "state of assistance" to a "state of social investment", the latter is also inherent in modern liberalism.

These changes also imply a change in the nature of work itself. In turn, with the change in the nature of work, the nature of ownership also changes. Social democrats, after moving to a position of macroeconomic policy that clearly recognizes the importance of the private property institution, have thus affirmed the idea of recognizing an inalienable human right - the right to property that is legally enshrined.

The same positions are supported by a contemporary conservatism. However, it should be noted that a number of provisions that form the basis of the Western model of the welfare state were elaborated in the process of social-democratic and liberal ideas' convergence.

The synthesis of liberalism, social democracy and conservatism depends on the ratio of the components of ideas, values and principles of their ideologies, on the conditions and needs of social reality, the subjects who study and use this direction.

A vivid example of the synthesis of these ideological phenomena's traditional political values in the history of their existence, is the new ideological form that has emerged in this process - neo-conservatism.

This socio-political phenomenon was generated by a specific historical situation and globalist processes in the middle of the second half of the twentieth century. It came about when traditionally conservative, liberal and social-democratic principles, norms and attitudes, inherent in all their ideological theory and practice, and used directly in the process of reforming the world system in the twentieth century, lost their effectiveness, and their methods did not meet the requirements of the time.

${ }^{6}$ Сковронський Д. М. Сучасні моделі соціальної держави. Вісник Національного університету “Львівська політехніка”. Серія: Юридичні науки : зб. наук. праць. 2016. № 850 . C. $265-267$. 
Neo-conservatives united on the basis of the objective need to use radical methods and means to undertake economic recovery, based on technological progress which implies state intervention in this sector and greater freedom of market relations, free competition and private property. Criticizing the state's virtues in the social sphere, they suggested that the public sector of the social services be partially privatized. Unlike liberalism and conservatism, special attention is paid to the internal and external policies of the state. In political sphere, they give priority to pluralism, the protection of citizens' rights, the protection of individualism, the rights of private property, the pursuit of traditional specific national and ethnic values along with the universal values, the state is seen as the guarantor and defender of law and morality, it must provide freedom and privacy. Neo-conservatives prefer authoritarian principles, oppose excessive democratic freedoms, for domination of the state they imagine, for using forceful methods in solving socio-economic and political problems, etc.

At the same time, its novelty is relative, because it is based on the ideas and principles of classical conservatism, liberalism and social democracy. Its peculiarity is the reaction to their miscalculations and mistakes.

On the other hand, based on its contemporary social orientation, it is increasingly approaching social democracy, which is based on the principles of solidarity and justice. And finally, there are a number of central provisions of conservatism distinguished in its political orientation: the priority of subordination of the individual to the state and provision of the political and spiritual unity of the nation, the transition to innovation by means of a deep understanding of the possible consequences of action, upholding the existing state and social order, stability, social institutions (strengthening families, churches, voluntary organizations, etc.), which are the basic units for moral, spiritual, cultural formation of the individual, etc.

Therefore, evolutionary changes in the world political and ideological doctrines in the present conditions of dynamic development of society and civilization are manifested at the level of mutual adjustment and restraint. These manifestations are achieved provided that each of the ideologies enters the relations of this kind with another ideology as an opponent, based on the specific needs and conditions of the state of society and civilization. At the same time, what is important is the internal motives of each ideology which underlie the reaction to the modernization processes and their results (both positive and negative), the degree of effectiveness and influence on the political and the whole spiritual climate of the world system, the constancy of authority as their own and competing ideology; awareness and determination of one's position in an ideological hierarchical structure in a particular historical period. In this regard, it is of particular importance to evaluate one's own principles, goals and objectives, as well as opposing ideologies. 


\section{CONCLUSIONS}

The history of political thought shows that the main differences between liberalism, social democracy and conservatism lie in the assessment of the paths to the goal, in their obligations towards a particular social entity, in the assessment of current changes, in the scale of values, in priorities.

At the same time, based on the fact that ideology, in its nature, is represented by ideological, worldview constructs that are the product of the human mind, thinking style, emotional and psychological orientations and priorities of the individual and his practical activity, determined by social objective and subjective motives, it turns out that it is constantly subject to change, which, in turn, leads to new forms of thinking. Thus, no ideology can in its singularly isolated existence, nor in their quantitative unity, constitute a universal, complete theoretical model. Definitely, a purely liberal, social-democratic, conservative and other models of social order and dynamic development of society and civilization as a whole do not exist. This is mainly due to the fact that the very conditions and peculiarities of the formation, development and practical realization of the ideologies under consideration at each historical stage of social evolution, determined the process of their permeation, complementarity and interdependence, both in theoretical and practical aspects.

At present, internationally, these ideological phenomena have more common than different points, they defend freedom of the individual, economic freedom, inviolability of private economic initiative and private property, free market economics, constitutional state, the prevalence of laws and their value, etc. Freedom for them is not considered to be an absolute value, because its existence is allowed only within the necessary limits and responsibilities.

At this stage of their development, the analyzed ideologies have diverged from their previous methods and mechanisms used in meeting the needs of social groups and their organizations and addressing the emerging issues. Liberals, conservatives, and social democrats are convinced that the demands put forward by society can be solved and implemented by peaceful means, gradual evolutionary transformations. The transition to a more sophisticated social system should be not forceful, but gradual and transformational.

\section{SUMMARY}

The basic modern values and principles of the three world ideologies, namely, liberalism, social democracy and conservatism, have been identified and analyzed. It has been revealed that the fundamental values and principles for liberalism are freedom, individualism, equality; freedom, equality, social justice and solidarity are at the heart of the social-democratic phenomenon; for conservatism, the main ones are stability, law and order, tradition. It is noted that among the wide range of value orientations in any ideology, there are in reality several basic values that are recognized by most people in democratic 
societies and integrate ideologies that are amenable to analysis. The main factors that led to the modern orientation of the world political and ideological doctrines' evolution were analyzed. The basic changes in their outlook constructions which occurred in a number of normative value provisions and principles, were described. It was concluded that a lot of principles, attitudes, values, norms of complex worldview constructions, which used to be a field of brutal struggle, underwent significant historical changes in the course of human civilization development and at the present stage are closely intertwined and have become a common property. It is emphasized that in spite of the tendencies of convergence of liberalism, social democracy and conservatism in the ontological sense, there are significant differences between them.

\section{REFERENCES}

1. Попович М. Соціал-демократична позиція в умовах України. Лівочентристська перспектива Украйни: збірник експертних матеріалів. URL: http://www.online.km.ua/igs/leftcent.html\#0

2. Притуляк С. I. Український вимір світової соціал-демократії періоду постбіполярності: пошук оптимальної моделі взаємодії. Прикарпатський вісник НТШ : наук. журн. Івано-Франківськ. Думка. 2013. № 3(23). С. 119-120.

3. Данилишин Б. Лібералізм і консерватизм - Інь і Янь. Дзеркало тижня. Вип. 45. № 1220, 24 листопада - 30 листопада. URL: https://dt.ua/gazeta/issue/1176

4. Кулєшов О. В. Проблема цінностей в сучасному консерватизмі. Вісник Черкаського університету. Серія Філософія. Випуск № 31 (324). Черкаси, 2014. С. 21-28.

5. Слободян В. Консерватизм як ідеологія державотворення: етапи становлення. Державне управління та місиеве самоврядування. 2015. Вип. 3. С. 62-71.

6. Сковронський Д. М. Сучасні моделі соціальної держави. Вісник Національного університету “Львівська політехніка”. Серія: Юридичні науки : зб. наук. праць. 2016. № 850. С. 264-271.

Information about the author: Natalia Hedikova,

$\mathrm{PhD}$ in Political Sciences, Professor, Professor at the Department of Political Science and Law,

State Institution "South Ukrainian National Pedagogical University named after K. D. Ushynsky" 26, Staroportofrankivska str., Odesa, 65020, Ukraine 


\section{THE PHENOMENON OF POLITICAL MULTIBRANDING IN MODERN UKRAINE}

\section{Halyna Shchedrova}

\section{INTRODUCTION}

Branding has become an integral part of modern economic relations, marketing, information and cultural sphere as a process of constant commitment to a particular product (both tangible and intangible). Policy has not been an exception in the development of appropriate strategies, the formation of tools and approaches to branding on globally, regionally and personalized levels. Political branding is one of the determining factors in the transformation of the political environment, the search for optimal ways of positioning, recognizability and methods of competition. In addition, branding can contribute to the development of modern political culture, communication in society, a consolidating marker in the formation of a balanced system of relations between government and civil society at the state level.

The importance of researching the problem of branding determines the scientific and practical interest in it by domestic and foreign scientists in the context of political culture and consciousness, political communication, political psychology and other fields of knowledge, whose research analyzes conceptual and empirical aspects of formation and implementation brands. The theoretical substantiation of the political brand formed the basis of scientific research of such Ukrainian scientists as $\mathrm{S}$. Veleshun, O. Yevtushenko, G. Kuts, T. Nagornyak, I. Prysyazhnenko, G. Shevchenko, research on branding of the state and territories is carried out by O. Korchagina, N. Lyutko, D. Yatsyuk, branding of political parties N. Lisovska, K. Pavliuk, A. Rudenko and others.

It is relevant such areas of activity as the search for optimal brands of the state, territories, state institutions in conditionals of choosing a stable and consistent state strategy in Ukraine. Equally important is the development of practices in the formation of political brands of parties, organizations and other political actors. This complex course of processes determines the feasibility of using the concept of "political multibranding", the essence of which requires categorization taking into account the current state of domestic policy.

Political brand is an element of competition for power. Its creation is part of the study of the electoral field, target audiences, the dominant agenda of society. Ukraine has already had enough meaningful cases in the 
implementation of political branding. The study of their specificity makes it possible to determine the level of sustainability of the political institutional sphere and in general the state of democratization of political power relations.

\section{Branding as a technology and tool of the formation recognizability and commitment to the object}

Branding was borrowed from the economic sphere as an activity to create a lasting commitment to a product / object to socio-political categories. The concept and process is used in terms of creating a brand of the state, country, territory, personal brand and so on in the political plane. All these types of branding are widespread in the West and are experiencing an active phase of formation in modern Ukraine.

The concept of "brand of the state" is often associated with such phenomena of cultural and informational perception as "image of the state" and "vision of the state". However, if the first is defined as a set of rational and emotional ideas arising from the comparison of all features of the country, the historical experience of its population, the forms of communication it uses, the second is a product of centuries-old synthesis in the public consciousness and culture of the nation of some original ethno-national characteristics ${ }^{1}$. In turn, the "brand of the state" is a collective image of a particular political system, parties, politicians and statesmen, which corresponds to reality and is associated with the objective interests of the nation with its unique features.

State, national, regional and global branding are not linear and single-order categories. Thus, state branding is a type of political branding, and global, national and regional are the areas of territorial branding, which are aimed at improving the perception of national sovereignty and its constituent regions by residents and external observers. The branded items are the state as a political institution in the first case, and in the second the territory with "claims" of different levels².

Branding is an important aspect of communication. A well-known expert in the field of branding of states and territories S. Anholt emphasizes this. In his opinion, the brand is a general context of external communication and reputation of states ${ }^{3}$. Analyzing the factors influencing the popularity of the state (culture, tourist interest, politics, economy, social climate, etc.), the British scientist formed a rating of attractiveness of countries, the calculation of which was based on the following components:

${ }^{1}$ Шевченко Г. Політико-інформаційний вимір державного брендингу України. Автореф. на здобуття наук. ст. кан. політ. н. КНУ ім. Т. Шевченка, 2009. С. 8-9.

${ }^{2}$ Нагорняк Т. Брендинг територій у сучасних політичних практиках. Грані. 2014. № 3 (107). C. 54.

${ }^{3}$ Anholt A. Beyond the Nation Brand: The Role of Image and Identity in International Relations. URL: www.exchangediplomacy.com. 
- exports (estimates of the inhabitants of different countries about goods that they either choose or ignore);

- governance (public opinion on the competence and openness of the country's leadership - it is a measure of individual perception of government; assessment of justice, democracy, environmental protection, etc.);

- culture and heritage (assessment of the historical heritage of the country and the state of its modern culture);

- tourism (level of interest in visiting the country, interesting and attractive tourist attractions);

- investment and immigration (attractiveness of the country for living and investing in the economy);

- people (their education, openness, or vice versa their hostility and discrimination $)^{4}$.

Components of the measurements of the index of national brands of the world "Future Brand Country Brands Index" complement the methodology of state branding. They are based on a kind of evaluation hierarchy of decisions, which ultimately give an individual assessment of the state brand:

- human awareness of the existence of the country and its capabilities;

- associations and stereotypes about the country;

- business potential, quality of life and value system;

- respect, authority of the country;

- the decision to visit the country and the factors that prompted its adoption;

- a person's desire to tell acquaintances about the country ${ }^{5}$.

Another related concept is the "branding of territories", which's been perceived by modern political science in several forms. First, it can be identical to the direction of policy as a long-term and holistic policy of development of the territory in order to self-organize on a value basis as a policy actor ${ }^{6}$. Secondly, the branding of territories acts as a political technology, the relevance of which increases during election campaigns, it is also a kind and component of personal and group strategies of capital conversion in the political field.

Spatial branding is embodied in the brand of the country as a set of characteristics (name, sign, image, symbol, term, slogan, etc.), which united

${ }^{4}$ Anholt A. Beyond the Nation Brand: The Role of Image and Identity in International Relations. URL: www.exchangediplomacy.com.

${ }^{5}$ Баровська А. Брендинг держави в контексті Євро-2012: виклики та перспективи. Аналітична доповідь. НІСД. 2011. URL: http://www.niss.gov.ua/content/articles/files/evro 2012-ff728.pdf.

${ }^{6}$ Нагорняк Т. Брендинг території як державна та регіональна політика: Монографія. “Ноулідж”. 2013. С. 70-75. 
of the idea of the country itself, contain exclusive and positive characteristics of the country and distinguish it from others in the world ${ }^{7}$.

The concept of "political brand" is mainly perceived as a characteristic of certain political forces and institutions, it includes a range of relationships, attitudes and rational constructions that have developed in society regarding the actions and statements of the branding entity. Political brand includes a number of mandatory components as a multicomponent construction, in particular, slogan (verbal symbols when positioning a brand), cover brand (background on which the slogan is placed), visual brand (shape, geometric shape) and personal brand filters, like political actors (brand personalities if they are direct political leaders, or brand faces if they are a public representative of a political force, etc.).

The effectiveness of a political brand is measured by such characteristics as:

- brand strength, ie the ability to dominate within a certain political space;

- compliance of the brand with the needs and interests of the audience;

- ability to increase the number of supporters and spheres of influence;

- the level of public support and the probability of choosing a specific political entity if there are other alternatives;

- the degree of popularity of a political brand, measured by quantitative characteristics ${ }^{8}$.

The directions of realization of a successful brand were once described by the Swedish conceptualist T. Ged. His theory of "four-dimensional branding" includes rational, emotional, spiritual and social directions. In the work "4-D Branding" he emphasized that branding in the XXI century requires perception and imagination, as well as the constant development of relationships between supplier and consumer of the product. What is important is the author's thesis that today brands are built around relationships, not around things or products. Thus, from the sphere of physical brands moved to the sphere of psychological and political. It's explained as brands are now associated with the values with which the individual identifies, and therefore values define brands ${ }^{9}$.

Instrumental aspects of branding are the subject of scientific research and approbation workshops. Thus, the researcher L. Vincent in his work "Legendary Brands" explores "brand mythology", understanding it as a "brand story that creates a kind of existential connection between the

\footnotetext{
${ }^{7}$ Колесницька Н. Територіальний брендинг: науково-методологічні підходи до визначення та формування. Наукові праці. Політичні науки. 2012. № 185. Т. 197. С. 48.

${ }^{8}$ Поветьев П. Бренд коммуникация в публичной политике: концептуальные основы. URL: http://www.nirsi.ru/analitic/Brand-kommunikaciya_v_publichnoy politike.pdf.

${ }^{9}$ Гэд T. 4D брэндинг: взламывая корпоративный код сетевой экономики. Манн, Иванов и Фербер, Стокгольмская школа экономики в Санкт-Петербурге. 2005. 232 с.
} 
consumer and the brand"10. The American strategist D. Atkin in his book "The Cult of Brands" argues for the existence in modern society of "brand communities" that are supporters of brand cults ${ }^{11}$. The author clearly demonstrates how the commercial sphere has become a certain "religion", and the belief of it grows with each demonstration of the idea and value of the brand.

According to the French culturologist J. Baudrillard, in order to become a desirable object of consumption, every thing must become a sign. The scientist introduces the concept of "simulacrum". It's a construction in which the difference between real and imaginary disappears. In essence, J. Baudrillard interpreted the whole modern world as a world of ideas that correlate little with reality, but those that are perceived as not just reality but "super reality" . The basic tool in building a brand with such an approach should be advertising - a kind of brand discourse. An imaginary concept is created with the help of constant reproduction of advertising images and plots, which is easily perceived by the public consciousness as reality.

Ukrainian researcher G. Kutz points out that influencing the recipient's behavior is the most important goal of brand management. That is why branding is actively used in the modern political space, in particular, in electoral processes, in the positioning of political parties, the formation of the image of political leaders, the creation of the image of the state and so on. According to the author, this is due to the fact that in modern conditions, the brand is a long-term unique competitive advantage ${ }^{13}$. Indeed, brands establish a trusting link between the electorate and the political class, as brands provide certain guarantees not only about the expectations of the recipients, but also about the predictability of the behavior of a particular political force or political leader.

The basic principles of political branding were formulated by the French political scientist and political consultant J. Segel. These principles underlie the direct political activity of their author, who claimed that he "created brands in the image and likeness of people, just as God created the latter. But people are mortal, and brands can count on immortality"14. J. Segela emphasized that today states must act by analogy with global corporations,

${ }^{10}$ Винсент Л. Легендарные бренды: Раскрученные рекламные мифы, в которые поверил весь мир. ФАИР-ПРЕСС. 2004. С. 26.

${ }^{11}$ Аткин Д. Культ брэндов: как сделать покупателя единомышленником. АCT: Транзиткнига. 2005. С. 163.

${ }^{12}$ Бодрийяр Ж. Злой демон образов. Искусство кино. 1992. № 10. С. 65-69.

${ }^{13}$ Куц Г. Ідентичність бренду: політико-регіональний вимір. Гілея: науковий вісник. 2013. № 73. C. 306-308. URL: http://nbuv.gov.ua/UJRN/gileya_2013_73_139.

${ }^{14}$ Вице-президент HAVAS Жак Сегела: Креативность - это командная игра, а не одиночный спорт. URL: https://www.sostav.ru/publication/vitse-prezident-havas-zhak-segelakreativnost-eto-komandnaya-igra-a-ne-odinochnyj-sport-27283.html. 
which focus on creating brands and intangible assets, because in today's world the brand is valued much higher than factories and technologies. The role of a leader is very important for a successful brand, because just as a political party cannot exist without its hero, so people in the media age need bright images. According to the political scientist, first of all the voter votes for the personality, and not for the program at all. A political party that does not have a standard-bearer and a bearer of an ideal is doomed to failure. Success is impossible if the party does not have a leader whose image corresponds to his electorate ${ }^{15}$

Ukrainian political scientist A. Rudenko identifies such party technologies which's based on the marketing strategy of positioning Ukrainian political parties. They are:

- naming (development of the name of a political party);

- definition of brand persons of the party;

- creation of an ideological platform and formation of a party program;

- development of design of party symbols and advertising products;

- party branding ${ }^{16}$.

Comprehensive using of these technologies provides both the formation of the party brand and the construction of the party image as the technology of creating a certain image, which involves the introduction of information about the party, the formation of a set of problems to be positioned, party identification with its audience segment ${ }^{17}$. It is also important to distinguish between the scientific categories of "party brand" and "party product", because the party brand is rooted in the mass consciousness, symbolic content, emotional load and the ability to combine several political goods. Party brand is a result of political marketing. It is interpreted by A. Rudenko as a kind of unique proposal of a particular political party ${ }^{18}$.

Branding technology for a political party is a necessary condition for the formation of the target audience, and hence the future electorate. Creating a political brand is one of the main resources for successful participation in a competitive political struggle, because, as already noted, in the modern political world there is a struggle of brands, not ideologies or programs.

\footnotetext{
${ }^{15}$ Сегела Ж. Национальные особенности охоты за голосами: 8 уроков для кандидата победителя. Вагрус. 1999. С. 52.

${ }^{16}$ Руденко А. Технології політичного маркетингу в діяльності політичних партій України. Дис. на здобуття наук. ст. канд. політ. н. ДНУ ім. Василя Стуса. 2017. С. 27.

${ }^{17}$ Сакрієр О. Технології конструювання іміджу лідера політичної партії у парламентських виборчих кампаніях України. Автореф. дис. на здоб. наук. ст. канд. політ. н. Чернів. наи. університет ім. Ю. Федьковича. 2012. С. 8.

${ }^{18}$ Руденко А. Технології політичного маркетингу в діяльності політичних партій України. Дис. на здобуття наук. ст. канд. політ. н. ДНУ ім. Василя Стуса. 2017. С. 3.
} 


\section{Multibranding as a phenomenon of Ukrainian politics}

The concept of branding covers areas from art to production and politics in the modern world. Despite the fact that politics has the least specificity, this aspect of public life gives the biggest dividends, in particular, in the form of control over both art and production. Branding as an activity to create a lasting commitment to a particular product in the field of economics entered the political plane of the Western world in the middle of the twentieth century and began to be actively used in domestic practices in the early 2000s. However, we consider the categorization of this concept exclusively in the dimension of product marketing strategies not sufficiently justified, especially given the specific features of modern public policy in Ukraine and public policy in the international arena.

Therefore, it is proposed to use the term "political multibranding" in the sense of a set of measures and techniques aimed at simultaneously ensuring the recognition and formation of a favorable attitude to the subject of political activity: the state, political leaders, their teams, related structures and more. The expediency of the proposed definition is due to the formation of such a political space in Ukraine, where public policy participants in addition to the usual elements in the form of public organizations or youth "wing" of parties may contain stable media products, power groups, structures that are identified with political force.

The practice of introducing multi-branding has been embodied both at the state and regional levels, as well as in modern political projects, in particular, parties, individual politicians, etc. This can be clearly seen in the example of an active campaign to form and promote a single advertising brand of Ukraine, which was approved by the Cabinet of Ministers of Ukraine in May $2018^{19}$.

The brand was proposed by the Ukrainian agency "Banda" in the framework of the Commission for the Promotion of Ukraine at the Ministry of Information Policy of Ukraine, as well as on the basis of proposals from British partners. According to the Ministry of Information Policy, they worked on the development of the brand for almost a year. They were created several variants of concepts of promotion of Ukraine, which were shown to six focus groups in Great Britain, Germany and Poland. The experts concluded that the new, and in fact the first, state-approved brand was designed to improve the world community's perception of Ukraine, which is

\footnotetext{
${ }^{19}$ Уряд схвалив новий бренд “Україна Зараз”, що забезпечить єдиний стиль презентації держави в світі. Урядовий портал. URL: https://www.kmu.gov.ua/news/uryad-shvaliv-novijbrend-ukrayina-zaraz-sho-zabezpechit-yedinij-stil-prezentaciyi-derzhavi-v-sviti.
} 
currently "associated with three things - revolution, corruption and war",20 (Fig. 1). Also among the goals of promoting the approved brand was to attract investment to the country and improve tourism potential. The logo was described as dynamic, open and positive - the way the world should see Ukraine right now.

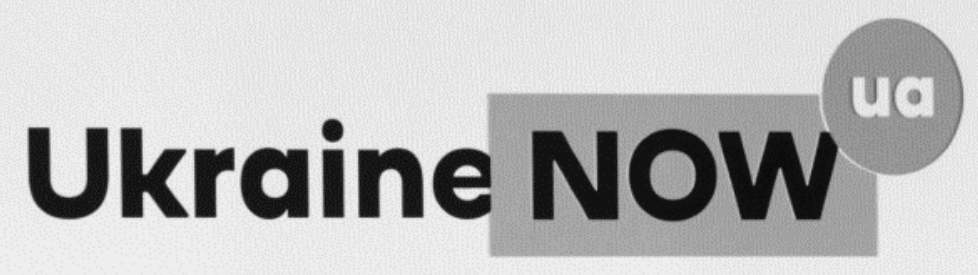

Fig. 1. The single brand of Ukraine "Ukraine NOW UA"

The brand of Ukraine was historically formed in Soviet times. It positioned the country as a "granary" of the territories of the socialist camp. This association also identified markers of the use and perception of Ukraine, and the appeal of the world community to it. Such a tradition determined the consumer attitude to Ukraine and, as a consequence, the formation of such clichés as "raw material base", "appendage" and so on. The new logo and its presentation indicate that the brand is developed for a foreign audience. In her imagination, a new visualization of Ukraine was to emerge without a wellestablished symbolic perception (sunflowers, ornaments, deer, etc.). Given that the content of the brand (the descriptive part of the underlying meanings), has not been disclosed, we assume that the primary goal is to put Ukraine on the agenda of the international community. This is a kind of continuation of the then diplomatic activity of the state leadership and a reasonable need for the time when the country was experiencing acts of military aggression in the Donbass.

${ }^{20}$ Кізілов С. В України з'явився рекламний бренд. Украӥнська правда. 2018. URL: https://www.pravda.com.ua/news/2018/05/10/7179891. 
Due to the formation of a holistic and meaningful brand of the state, it is possible to ensure the implementation of a number of important (urgent and strategic) functions. At one time, this aspect of branding was revealed by Ukrainian researcher G. Shevchenko. In her dissertation research, she substantiated the thesis that state branding allows to spread both universal features of Ukrainian political culture (support of democratic values; rule of law; promotion of the idea of good, justice, guarantees of life rights, protection of citizens and their freedoms; formation of European identity) and and original (unique) national worldviews that demonstrate national-state identity (creation and promotion of cultural and information products that contribute to the positioning of the state brand in all its manifestations) ${ }^{21}$.

Multiculturalism and multinationality of Ukraine is one of the winning factors in promoting such a brand in the world in the context of forming a state brand, because taking into account all regional authenticity shows the support of the country's ethnic population at the state level. It is also another tool for promoting Ukraine's tourism brand on the model of other European countries, whose tourist regions have become recognizable in the world due to a planned and systematic policy, providing, in particular, economic and financial dividends and reputational advantages in the international arena.

Given the above arguments, it can be argued that the consequences of successful implementation of state branding of Ukraine should be:

- promotion of the political ideology of the state in the international arena;

- strengthening the position of Ukraine in the world political and cultural space;

- improving the country's competitiveness in the field of foreign economic relations, tourism and cultural exchange;

- effective formation of national identity;

- consolidation of internal resources and international support in counteracting external challenges and military threats, which are an urgent problem of modern Ukraine.

As a result, Ukraine must find its place with a positive associative number. The current emphasis in the implementation of the state brand is focused primarily on overcoming the negative, or stereotypical, perception of Ukraine in the world, rather than on the presentation of benefits and achievements that would be unique or have a positive image potential. Accordingly, over time, the state brand should be supplemented with a list of what Ukraine is right now (Ukraine NOW).

\footnotetext{
${ }^{21}$ Шевченко Г. Політико-інформаційний вимір державного брендингу України. Автореф. на здобуття наук. ст. кан. політ. н. КНУ ім. Т. Шевченка, 2009. С. 3.
} 
The official branding of territories (regions, communities, cities) has been continued since 2016 along with the formation of the state brand in Ukraine. In contrast to the national trends in the regions, the approach is more traditional - both in the visual part and in relation to the selected slogans. For example, Khmelnytsky region began to position itself as a "crossroads of elements and stories", while choosing an original ornament. Transcarpathia has secured the brand of "land close to the sun" with a corresponding mountain landscape on the logo. It's became natural the symbolic image of a lion on the brand of Lviv region. Cherkasy, Kyiv, Vinnytsia, other oblasts, cities, united territorial communities and settlements have started to develop their official brand. However, it should be noted that the attention of the regions is focused exclusively on finding their tourist brands, which speaks volumes about the purpose of such searches.

Despite the fact that the category "brand" has aproached recently in relation to the territories of Ukraine, but regions and cities still had individual perceptions and established statuses, such as Luhansk region is the dawn of Ukraine, Kharkiv is the student capital, Lviv is cultural capital, Donetsk region associated with mining, and Odesa associated with the sea, Kyiv is the mother of Russian cities and more. Such definitions are dictated by historical development, the specifics of infrastructure, socio-cultural dominants and other factors. Obviously, these are traditional, and therefore autonomous brands that do not lie in the plane of implementation of the relevant state policy. We assume that these symbols will coexist for a long time with the results of modern branding in Ukraine.

Usually, state brands are purposefully formed by relevant companies and specialists working on a tender basis. For example, in Scotland the national brand was promoted by the marketing company CLK, which offered Scotland the Brand to the world. In Poland, it is the Corporate Profiles DDB agency, which has developed a national logo, slogan and marketing campaign in general. There is no single national brand promotion strategy in Canada Garneau, Wurstlin, Philp: Brand Engineering, which offers to advertise Canada as a "junior version of the United States", and Taxi Advertising \& Design, which focuses on innovation and creative potential of the country ${ }^{22}$.

The criteria for evaluating and measuring brands are: the value of the brand (state branding), and the level of recognition, electoral and interelectoral support ( a brand of a political entity).

Every year, the international company "Brand Finance" publishes a report on the value of national brands in the world. According to the report "Brand

\footnotetext{
22 Державна політика у сфері національного брендингу: Інформаційна довідка, 2016. URL: https://www.radaprogram.org/sites/default/files/infocenter/piblications/29157.pdf.
} 
Finance Nation Brands 2019", the United States continues to dominate the world rankings ${ }^{23}$. From 2018, the second and third places remain unchanged. They are China and Germany. Also in the top ten are Japan, Britain, France, India, Canada, South Korea and Italy. The value of these national brands ranges from 27.75 billion dollars. The United States in the United States to 2.1 billion dollars. USA in Italy. In the Top 100 world brands, Ukraine ranked 56th in 2019, rising by two positions compared to 2018. Its neighbors on the scale "Brand Finance" - Luxembourg and Greece. Perception of Ukraine as a developing brand is the achievement of an active process of branding, presentation of the country at the highest level of international relations, the correct definition of priorities.

Another area of multibranding in Ukraine is the formation of brands of political actors (parties, organizations, political leaders, their teams, etc.). Ukraine has several illustrative cases in this direction, which, have different degrees of effectiveness. Back in the early 2000s, the country began to embody and develop the brand of "regions", which was institutionally embodied in the activities of the political party "Party of Regions", its youth wing ("Young Regions"), a clear identification with industrial regional centers (despite the headquarters was located in Kyiv), visual identification with a white and blue background and personalized perception through the leaders of the "Party of Regions" (V. Yanukovych, B. Kolesnikov, M. Azarov, $\mathrm{O}$. Vilkul, etc.). The successful period of multi-branding is characterized by victories in two parliamentary elections (2006 and 2007), winning 187 seats in the Verkhovna Rada as a result of the 2012 elections, the victory of the party leader in the 2010 presidential election, expulsion from the party of its leading leaders, withdrawal from the party of hundreds of thousands of its members in all regions ${ }^{24}$. Today, the brand of "regions" has lost both credibility and trust. The return of part of the team to the political sphere is accompanied by the implementation of completely different political brands ("Our Land", "Opposition Bloc", "Opposition Platform - For Life", etc.).

Another example with the opposite background is the Right Sector. This is a brand that has in its structure: the political party "Right Sector", the Voluntary Ukrainian Corps "Right Sector", the public organization "Right Youth". Officially, the structure has a common name National Liberation Movement "Right Sector" 25 . The goals of the organization are embodied in

\footnotetext{
${ }^{23}$ Brand Finance Nation Brands. URL: https://brandfinance.com/images/upload/ nation_brands_100_2019_free_1.pdf.

${ }^{24}$ Центральна виборча комісія: Офіційний веб-сайт. URL: https://www.cvk.gov.ua/ vibory_category/vibori-narodnih-deputativ-ukraini.html.

${ }^{25}$ Національно-визвольний рух "Правий сектор": Офіційний веб-сайт. URL: https://pravyysektor.info/pro-ruh.
} 
the official slogans: "A force that protects!", "Born on the Maidan! Tempered by war!","For the Ukrainian Independent Conciliar State!". The colors of the brand are red and black.

The "Right Sector" is a successful example of a multi-brand, because in the process of constant transformation, the organization has retained all the functional segments of its structure. It's being started its existence during the Euromaidan (November 2013) in the format of a situational association of right-wing activists, the movement was transformed into a volunteer battalion (July 2014) and took part in hostilities in the east of the country. With the beginning of preparations for the 2014 parliamentary elections, the Right Sector political party is being separated from the paramilitary formation of the Right Sector State Unitary Enterprise. The election to the Verkhovna Rada resulted in $1.8 \%$ of the electorate's support and only one seat in parliament that of party leader D. Yarosh, who won in a single-member constituency ${ }^{26}$. One of the reasons for the party's loss in the elections is the lack of consolidated cooperation with other right-wing political forces and candidates (Svoboda, Congress of Ukrainian Nationalists), which also failed to get into the Verkhovna Rada. The formation of a joint brand would minimize reputational losses and implement a successful election campaign (these political parties received a total of $6.56 \%$ of the vote $)^{27}$.

Despite the lack of success in political activities, the Right Sector remains an active participant in the socio-political life of Ukraine, supporting the functioning of all its cells and structural units. The organization has been in the spotlight through a number of lawsuits involving the organization's fighters during 2015-2017. This only added points in the recognizability rating to the structure, which already has a well-established positioning.

Finally, consider one of the most successful cases of multibranding, namely the format "Servants of the People", the image characteristics of which had presented in the film of the same name 3.5 years before the start of public policy. The implementation of the multi-branding strategy began with the registration of the "Servant of the People" party at the end of 2017. In 2019 , one of the party's founders V. Zelensky won the election of the President of Ukraine, receiving $73.22 \%$ of the vote ${ }^{28}$. Subsequently, the

${ }^{26}$ Центральна виборча комісія: Офіційний веб-сайт. URL: https://www.cvk.gov.ua/ vibory_category/vibori-narodnih-deputativ-ukraini.html.

${ }^{27}$ Центральна виборча комісія: Офіційний веб-сайт. URL: https://www.cvk.gov.ua/ pls/vnd2014/wp300pt001 f01=910.html.

${ }^{28}$ Центральна виборча комісія: Офіційний веб-сайт. URL: https://www.cvk.gov.ua/ pls/vp2019/wp300pt001f01=720.html. 
Servant of the People political party $(43.16 \%)$ also won the parliamentary elections, forming a mono-majority in the Verkhovna Rada ${ }^{29}$.

Today, the "Servant of the People" brand is a political party, a faction in the parliament, representations in the regions, and an active online platform, the "Servant of the People" - Zelensky's Team. The structure was named "Ze-Komanda" (after the first part of the name of the leader of the organization V. Zelensky) in general and formally,. The branding strategy, especially in its visual and verbal symbols, was quite systematic and logical: the color of the brand is green, the slogans are "President / MP is a Servant of the People", "Let's make them together", "Spring is coming - we will jail", "Let's create a country dreams "and others. In the context of the political process, the slogans changed according to the situation, the priorities of the President and parliamentarians.

Positive experience of branding "Servants of the People" is analytical work with the requests of the target audience, whose needs formed the basis of political slogans, consolidation of protests and frustrations in the policy of the state and turning them into high political dividends, successful choice of brand personalities which don't have a negative perception of ordinary citizens (V. Zelensky as a leader of a political force, D. Razumkov as a speaker and brand face of the election campaign). The described brand at the present stage is undergoing development, forming a regional office and adjusting the relevant representatives in the central government. In the future, the structure of the multibrand will be branched out with further specification of functions and tasks.

Considering the various formats of multibranding in Ukraine (from national to institutional) we can trace the political component in each of these processes. This is an integral feature of the transition period of state formation, when politicization accompanies the flow of all aspects of society. Thus, it is fair to say that all forms of branding in our country are somehow political. Moreover, this cases are examples of complex multilevel formation of brands as a kind of political multibrands.

Given the established forms of branding in Ukraine, it can be presented in terms of the following levels:

- macro level - branding of the state, country, separate territories (regions);

- local (institutional) - branding of political parties, public organizations, state institutions or structures (such as the branding of the New Police or an attempt to rebrand Ukrzaliznytsia);

\footnotetext{
${ }^{29}$ Центральна виборча комісія: Офіційний веб-сайт. URL: https://www.cvk.gov.ua/pls/ vnd2019/wp300pt001f01 $=919 . \mathrm{html}$.
} 
- personal - the formation of brand personalities individually or as a member of a political team.

Among the shortcomings that can be clearly seen in political multibranding in Ukraine, we note the predominance of form over content, when only the visual part is subject to update and less often - strategies, forms of their implementation, means of inter-institutional communication. By the way, branding is one of the forms of such interaction, because it always acts as a carrier of information. Another problem is also related to the communication sphere, as it is the weak interaction of political institutions and entities with the target audience, taking into account the needs and expectations of which is the key to successful brand building. Deformed or limited channels of communication between the bearer of the brand and the consumer, ie society, often have consequences not only in the form of rejection of the brand, but also such as deep crises in the state. Domestic modernity has several such examples ("Orange Revolution", "Revolution of Dignity"), which were preceded by large-scale public frustrations in the state course, political decisions and actions. Issues of overcoming and correcting such shortcomings should become part of further theoretical developments and empirical research on multibranding in Ukraine.

\section{CONCLUSIONS}

Brand formation from the state to a political party is an urgent requirement and need of the time, in which marketing strategies are part of all spheres of human community. The implementation of state branding is allown to ensure national interests by implementing its various models in interstate cooperation. In addition, the creation and support of state brands contributes to the formation of political identification of the population, adequate assessment of political alternatives and more. Currently, branding as an activity to create a lasting commitment to the subject, the reception of its optimal positioning and a tool to ensure visibility is carried out at the level of the state, country, territory, political institutions and actors.

Today, Ukraine is on the path of developing and implementing branding strategies at all levels, in particular, in the context of developing a policy of state support for the process of creating positive brands of the country and its regions. Such multi-vector branding, especially in the context of creating political brands, has led to the expediency of categorizing such a phenomenon as "political multibranding". It is defined as a set of measures and techniques aimed at simultaneously ensuring the recognition and formation of a favorable attitude to the subject of political activity: the state, political leaders, their teams, related structures, etc. At the same time, in the conditions of long political transition and transitive society, multibranding in Ukraine is rather 
asymmetric in terms of the ratio of concepts and real political practice. The transformation of political institutions focuses on visual branding, rather than on meaningful updating of the structure and approaches in its activities.

Domestic experience in brand formation has several successful cases, which are either developing (state brand "Ukraine NOW"), or have long-term and justified political success (brand "Party of Regions"), or implemented using modern and non-standard means of multibranding (case of political force "Servant of the People").

If the state multibranding is designed to promote the development of export, educational, investment, tourism, infrastructure and other potentials, the creation of brands in the party-political space will provide strategic planning of the political product for the long term.

\section{SUMMARY}

There are analyzed theoretical and applied aspects of formation and realization of branding of the states, the countries, territories, political institutes The correlation of the concepts "image of the state", "image of the state", "brand of the state" is understood as the aggregate image of a certain political system, parties, politicians and statesmen, which corresponds to reality and is connected with objective interests its unique features by the latter.

There're studied approaches to the evaluation of different types of brands, criteria for their effectiveness and popularity (such as the approach of S. Anholt). The research substantiates the idea that political branding is an important element of communication, because each brand is always a carrier of information that society either perceives or by its non-perception causes changes in the entire branding strategy.

It's given the specifics of branding in modern Ukraine, so it is proposed to use the concept of "political multibranding", categorizing it as a set of measures and techniques aimed at simultaneously recognizing and forming a favorable attitude to the subject of political activity: the state, political leaders, their teams, related structures etc.

Among the practices of forming political brands, the ones that have experience of complex brand formation, which has proven its effectiveness, are considered. They are based on the analysis of various forms of branding in Ukraine, and there are distinguished its macro level (state, territories), local or institutional level (parties, public organizations, state institutions) and personal level (political leaders).

\section{REFERENCES}

1. Аткин Д. Культ брэндов: как сделать покупателя единомышленником. АСТ: Транзиткнига. 2005. 272 с. 
2. Баровська А. Брендинг держави в контексті Євро-2012: виклики та перспективи. Аналітична доповідь. НІСД. 2011. URL: http://www.niss.gov.ua/content/articles/files/evro2012-ff728.pdf.

3. Бодрийяр Ж. Злой демон образов. Искусство кино. 1992. № 10. C. $64-70$.

4. Винсент Л. Легендарные бренды: Раскрученные рекламные мифы, в которые поверил весь мир. ФАИР-ПРЕСС. 2004. 336 с.

5. Вице-президент HAVAS Жак Сегела: Креативность - это командная игра, а не одиночный спорт. URL: https://www.sostav.ru/ publication/vitse-prezident-havas-zhak-segela-kreativnost-eto-komandnayaigra-a-ne-odinochnyj-sport-27283.html.

6. Гэд T. 4D брэндинг: взламывая корпоративный код сетевой экономики. Манн, Иванов и Фербер, Стокгольмская школа экономики в Санкт-Петербурге. 2005. 232 с.

7. Державна політика у сфері національного брендингу: Інформаційна довідка, 2016. URL: https://www.radaprogram.org/sites/ default/files/infocenter/piblications/29157.pdf.

8. Кізілов Є. В України з'явився рекламний бренд. Украӥнська правда. 2018. URL: https://www.pravda.com.ua/news/2018/05/10/7179891.

9. Колесницька Н. Територіальний брендинг: науково-методологічні підходи до визначення та формування. Наукові пращі. Політичні науки. 2012. № 185. Т. 197. С. 47-50.

10. Куц Г. Ідентичність бренду: політико-регіональний вимір. Гілея: науковий вісник. 2013. № 73. C. 306-308. URL: http://nbuv.gov.ua/ UJRN/gileya_2013_73_139.

11. Нагорняк Т. Брендинг території як державна та регіональна політика: Монографія. “Ноулідж”. 2013. 367 с.

12. Нагорняк T. Брендинг територій у сучасних політичних практиках. Грані. 2014. № 3 (107). С. 53-58.

13. Національно-визвольний рух "Правий сектор": Офіційний вебсайт. URL: https://pravyysektor.info/pro-ruh.

14. Поветьев П. Бренд коммуникация в публичной политике: концептуальные основы. URL: http://www.nirsi.ru/analitic/Brand-kommunikaciya _v_publichnoy politike.pdf.

15. Руденко А. Технології політичного маркетингу в діяльності політичних партій України. Дис. на здобуття наук. ст. канд. політ. н. ДНУ ім. Василя Стуса. 2017. 275 с.

16. Сакрієр О. Технології конструювання іміджу лідера політичної партії у парламентських виборчих кампаніях України. Автореф. дис. на здоб. наук. ст. канд. політ. н. Чернів. нач. університет ім. Ю. Федьковича. 2012. $20 \mathrm{c}$. 
17. Сегела Ж. Национальные особенности охоты за голосами: 8 уроков для кандидата - победителя. Вагрус. 1999. 262 с.

18. Уряд схвалив новий бренд “Україна Зараз”, що забезпечить єдиний стиль презентації держави в світі. Урядовий портал. URL: https://www.kmu.gov.ua/news/uryad-shvaliv-novij-brend-ukrayina-zaraz-shozabezpechit-yedinij-stil-prezentaciyi-derzhavi-v-sviti.

19. Центральна виборча комісія: Офіційний веб-сайт. URL: https://www.cvk.gov.ua.

20. Шевченко Г. Політико-інформаційний вимір державного брендингу України. Автореф. на здобуття наук. ст. кан. політ. н. КНУ ім. Т. Шевченка, 2009. 21 с.

21. Anholt A. Beyond the Nation Brand: The Role of Image and Identity in International Relations. URL: www.exchangediplomacy.com.

22. Brand Finance Nation Brands. URL: https://brandfinance.com/ images/upload/nation_brands_100_2019_free_1.pdf.

\section{Information about the author:}

Halyna Shchedrova,

Doctor of Political Sciences, Professor, Head of the Department of Political Science and International Relations, Alfred Nobel University 18, Sicheslavska Naberezhna str., Dnipro, 49000, Ukraine 


\section{NOTES}


Publishing house "Liha-Pres"

9 Kastelivka str., Lviv, 79012, Ukraine 44 Lubicka str., Torun, 87-100, Poland

Printed by the publishing house "Liha-Pres"

Passed for printing: February 7, 2020.

A run of 150 copies. 